Aus dem Institut für Pflanzenpathologie und Pflanzenschutz

der Georg-August-Universität Göttingen

Geschäftsführender Leiter: Prof. Dr. S. Vidal

\title{
Langzeitversuche zur Latenz von Xanthomonas campestris pv. pelargonii und Vergleich mikrobiologischer, serologischer und molekulargenetischer Nachweisverfahren
}

\author{
Dissertation \\ zur Erlangung des Doktorgrades \\ des Fachbereiches Agrarwissenschaften \\ der Georg-August-Universität zu Göttingen
}

Vorgelegt von

Hacer Batur-Michaelis

geboren in Imranli / Türkei

Göttingen, im Mai 2003 
Referent:

Korreferent:

Tag der mündlichen Prüfung:
Prof. Dr. A. v. Tiedemann

Prof. Dr. W. Zeller

Juli 2003 
Meinen Söhnen Maik und Dirk

und meiner Schwester Zeynep 
Seite

INHALTSVERZEICHNIS

ABKÜRZUNGSVERZEICHNIS $\quad \mathrm{X}$

I ENTWICKLUNG SEMISELEKTIVER MEDIEN FÜR

XANTHOMONAS CAMPESTRIS PV. PELARGONII, DEN ERREGER DER STENGELFÄULE UND BLATTFLECKENKRANKHEIT VON PELARGONIEN

1 EINLEITUNG

2 MATERIAL UND METHODEN

4

$2.1 \quad$ Herkunft der Bakterien 4

2.2 Medienvergleich 5

2.3 Verbesserung eines semiselektiven Nährmediums für Xcp 6

2.3.1 Bakterienvorkultur 6

$\begin{array}{lll}\text { 2.3.2 } & \text { Prüfung der semiselektiven Medien } & 7\end{array}$

$\begin{array}{lll}3 & \text { ERGEBNISSE } & 8\end{array}$

3.1 Vergleich diverser semiselektiver Nährmedien 8

3.2 Modifikationen mit dem MD5-Medium 12

$\begin{array}{lll}3.2 .1 & \text { Wirkung der Borsäure } & 12\end{array}$

3.2.2 Zugabe von Pepton und Bacitracin 13

3.2.3 Einfluss der Stickstoffzugabe 13

$\begin{array}{lll}\text { 3.2.4 Zugabe von Aztreonam } & 14\end{array}$

3.2.5 Zusammensetzung des alternativen semiselektiven MD5A-Mediums 15

3.3 Modifikationen des Tween B-Mediums 15

$\begin{array}{lll}\text { 3.3.1 Kombinationen verschiedener C-Quellen } & 15\end{array}$ 
3.3.2 Einfluss der Borsäurekonzentration mit und ohne Cellobiose 17

3.3.3 Wirkung verschiedener Antibiotika 19

3.4 Zusammensetzung des neuen semiselektiven TC-Mediums für Xcp 23

$3.5 \quad$ Wiederfindungsrate von Xcp im Pflanzenhomogenat 24

3.6 Überprüfung der Selektivität des neuen TC-Mediums 25

3.7 Wachstum verschiedener Xcp-Stämme auf dem neuen TC-Medium 28

4 DISKUSSION 30

$5 \quad$ ZUSAMMENFASSUNG 36

II EPIDEMIOLOGISCHE UNTERSUCHUNGEN ZUM 38

LATENTEN BEFALL

$1 \quad$ EINLEITUNG $\quad 38$

2 MATERIAL UND METHODEN 43

$2.1 \quad$ Chemikalien 43

$2.2 \quad$ Sterilisationstechniken 43

$2.3 \quad$ Bakterienstämme 43

$2.4 \quad$ Nährmedien 44

2.4.1 Hefeextrakt-Pepton-Natriumchlorid (nach RHODES, 1959) 44

2.4.2 Hefeextrakt-Dextrose-Kalk-Agar (nach LELLIOTT \& STEAD, 1987) 44

2.4.3 Tween-Cellobiose-Medium (nach BATUR et al., 1994) 44

2.4.4 NGA-Medium (nach MAVRIDIS) 45

2.4.5 NGAR-Medium $\quad 45$

2.4.6 NGAS-Medium 46

2.4.7 NGARS-Medium 46

$2.5 \quad$ Gewinnung von Antibiotika-resistenten Mutanten 46

2.5.1 Stabilität des Antibiotika-resistenten Stammes in planta $\quad 47$ 
2.6 Herkunft und Anzucht der Pelargonien 48

$2.7 \quad$ Anzucht der Bakterien 48

2.8 Einfluss der Temperatur auf die Vermehrung und Latenz von Xcp in 49 planta

2.8.1 Inokulation von zwei Pelargoniensorten mit dem Antibiotikaresistenten Stamm

$\begin{array}{lll}2.8 .2 & \text { Versuchsaufbau }\end{array}$

2.8.3 Gewinnung von Pflanzenextrakten zum Nachweis der Bakterien 52

2.8.4 Auswertung des Krankheitsbefalls 52

$2.9 \quad$ Untersuchungen zu möglichen Infektionswegen 53

2.9.1 Infektion über das Blatt 53

2.9.2 Infektion über die Schnittstelle 53

2.9.3 Infektion über die Wurzeln 54

2.9.4 Untersuchungen mit Stecklingen aus latent infizierten Mutterpflanzen 54

2.9.5 Infektion über das Gieß- und Sickerwasser 54

2.10 Besiedlung verwandter Unkräuter durch Xcp 55

2.10.1 Pikieren und Inokulation der Unkrautkeimlinge 56

$3 \quad$ ERGEBNISSE

3.1 Stabilität und Virulenz des Antibiotika-resistenten Xcp-Stammes in 57 planta

3.2 Bestimmung der Inokulumskonzentrationen mit der Antibiotika- 58 resistenten $X c p$-Mutante

3.3 Einfluss der Temperatur auf die Vermehrung und Latenz von Xcp in 59 planta bei verschiedenen Inokulumskonzentrationen

3.3.1 $25^{\circ} \mathrm{C}$ und $10^{5} \mathrm{cfu} / \mathrm{ml}$

3.3.2 $25^{\circ} \mathrm{C}$ und $10^{4} \mathrm{cfu} / \mathrm{ml} \quad 65$

$25^{\circ} \mathrm{C}$ und $10^{3} \mathrm{cfu} / \mathrm{ml}$

3.3.4 $15^{\circ} \mathrm{C}$ und $10^{5} \mathrm{cfu} / \mathrm{ml}$

3.3.5 $15^{\circ} \mathrm{C}$ und $10^{4} \mathrm{cfu} / \mathrm{ml} \quad 75$

$\begin{array}{lll}\text { 3.3.6 } 15^{\circ} \mathrm{C} \text { und } 10^{3} \mathrm{cfu} / \mathrm{ml} & 77\end{array}$ 
3.3.7 Zusammenfassung der Ergebnisse des Langzeitversuches 81

3.3.7.1 Inokulumskonzentration 81

3.3.7.2 Sortenvergleich 82

3.3.7.3 Einfluss der Temperatur 82

3.3.7.4 Einfluss der Düngung 83

3.3.7.5 Dauer der maximalen Latenz 83

3.3.7.6 Schwelle der Bakterienkonzentration in der Pflanze, die zu Symptomen 84 führt

3.3.7.7 Bakterienvorkommen in erkrankten Pflanzen 85

3.4 Untersuchungen zu möglichen Infektionswegen 89

3.4.1 Über das Blatt 89

3.4.2 Über die Wurzeln 90

3.4.3 Über die Schnittstelle 90

3.4.4 Durch den Samen 91

3.5 Untersuchungen an aus latent infizierten Pflanzen gewonnenen Steck- 91 lingen

3.6 Übertragung von $X c p$ in der Erde $\quad 92$

$3.7 \quad$ Übertragung durch Gießwasser 93

3.8 Vorkommen der Bakterien im Sickerwasser von Pelargonien 94

3.9 Anfälligkeit anderer Arten der Familie Geraniaceae für Xcp 94

$4 \quad$ DISKUSSION 96

4.1 Verwendung eines Rifampicin-resistenten Xcp-Stammes 96

4.2 Einfluss der Kulturtemperatur auf das Verhalten von Xanthomonas $\quad 97$ campestris pv. pelargonii in der Pflanze

4.3 Charakterisierung der Latenz 99

4.4 Faktoren, welche die Latenz beeinflussen 100

4.5 Systemische Ausbreitung der Bakterien in Pelargonienpflanzen 101

$\begin{array}{lll}4.6 & \text { Symptome } & 102\end{array}$

$\begin{array}{lll}4.7 & \text { Sortenvergleich } & 103\end{array}$

$\begin{array}{lll}4.8 & \text { Infektions- und Übertragungswege } & 104\end{array}$ 
$\begin{array}{lll}\text { 4.8.1 Infektion über das Blatt } & 104\end{array}$

4.8.2 Infektion über die Schnittstelle 106

$\begin{array}{lll}\text { 4.8.3 Infektion über die Wurzeln } & 107\end{array}$

$\begin{array}{lll}\text { 4.8.4 Übertragung durch Erde } & 107\end{array}$

4.8.5 Übertragung durch das Wasser 108

4.8.6 Übertragung durch den Samen 108

4.9 Vorkommen von Xcp auf anderen Arten der Familie Geraniaceae $\quad 109$

$5 \quad$ ZUSAMMENFASSUNG

III VERGLEICH VON ANTISEREN ZUM NACHWEIS 114

VON XANTHOMONAS CAMPESTRIS PV. PELARGO-

NII MIT VERSCHIEDENEN SEROLOGISCHEN METHODEN

$1 \quad$ EINLEITUNG

$\begin{array}{lll}2.1 & \text { Bakterienstämme } & 116\end{array}$

$\begin{array}{lll}2.2 & \text { Serologische Untersuchungen } & 117\end{array}$

2.2.1 ELISA (enzyme-linked immunosorbent assay) 117

$\begin{array}{lll}\text { 2.2.1.1 Allgemeine Methodik } & 117\end{array}$

2.2.1.2 DAS-ELISA nach BRIELMAIER-LIEBETANZ 118

2.2.1.3 DAS-ELISA nach RABENSTEIN 119

$\begin{array}{lll}\text { 2.2.1.4 Verwendete Puffer } & 120\end{array}$

2.2.1.5 Vorbereitung der Bakterien 121

2.2.1.6 Photometrische Auswertung 122

2.2.2 Fluoreszenztechnische Methoden 122

2.2.2.1 Verwendete Puffer 123

$\begin{array}{lll}\text { 2.2.2.2 Immunfluoreszenztest (IF-Test) } & 123\end{array}$ 
3.1 Die verwendeten Antiseren zum Nachweis von $X_{c p}$ im ELISA-Test

125

3.2 Antiserum der BAZ, Aschersleben

127

3.2.1 Ermittlung der optimalen Konzentration für das monoklonale Antiserum- und Serum-Konjugat

3.2.2 Ermittlung der optimalen Konzentration für das polyklonale Antiserum aus Aschersleben und die Konjugatverdünnung

3.3 Antiserum von BIOREBA

3.3.1 Nachweisgrenze von Xcp mit dem polyklonalen Antiserum der Fa. BIOREBA

3.3.2 Reaktion des BIOREBA-Antiserums gegenüber anderen $X c p$-Stämmen 132

3.3.3 Ermittlung der optimalen Antiserum- und Konjugatverdünnungen 133

3.4 Antiserum der Fa. LOEWE 134

3.4.1 Empfindlichkeit gegenüber verschiedenen Xcp-Stämmen 134

3.4.2 Nachweisgrenze bei Mischung mit Pflanzenextrakt 135

$3.5 \quad$ Antiserum vom IPO 136

3.5.1 Mischung mit Pflanzenextrakt 136

3.5.2 Empfindlichkeit verschiedener Xcp-Stämme im DAS-ELISA 137

3.5.3 Reaktion des IPO-Antiserums gegenüber anderen pyhtopathogenen 138 Bakterien

3.5.4 Einfluss der Probenaufarbeitung auf die Nachweisempfindlichkeit mit 140 dem IPO-Antiserum

3.5.5 Einsatz des DAS-ELISA zum Nachweis von Xcp in latent infizierten 142 Pelargonienpflanzen mit dem IPO-Antiserum

3.5.6 Nachweis von Xcp in Pelargonienpflanzen mit dem DAS-ELISA 4 Jah- 144 re nach Inokulation

3.5.7 Nachweis von Xanthomonas campestris pv. pelargonii mit dem IPOAntiserum nach einer Zwischenvermehrung

3.6 Vergleich der Antiseren zum Nachweis von Xcp-Reinkulturen 
Seite

3.7 Protokoll für den ELISA zum Nachweis von Xanthomonas campestris pv. pelargonii in latent befallenen Pelargonienpflanzen mit dem IPOAntiserum

3.8 Fluoreszenzmikroskopische Untersuchungen 149

3.8.1 Nachweis von Xcp mit Immuno-Fluoreszenz-Farbstoff 149

3.8.2 Fluoreszenzmikroskopischer Nachweis von Xcp in Suspension 149

3.8.3 Fluoreszenzmikroskopischer Nachweis von Xcp in latent befallenen $\quad 150$ Pflanzen

\section{DISKUSSION}

4.1 Antiserenvergleich 152

4.2 Empfindlichkeit der verwendeten Antiseren 153

4.3 Erhöhung der Nachweisempfindlichkeit 155

4.4 Spezifität der Antiseren 157

4.5 Nachweis von $X_{c p}$ in latent befallenen Pelargonienpflanzen durch das 157 DAS-ELISA-Verfahren

4.6 Nachweis von $X c p$ mit Hilfe der Immunfluoreszenz 158

5 ZUSAMMENFASSUNG

IV NACHWEIS VON XANTHOMONAS CAMPESTRIS PV. 162 PELARGONII MIT DER POL YMERASE-KETTENREAKTION (PCR)

1 EINLEITUNG 
Seite

$2.3 \quad$ Kultivierung der Bakterien 165

$2.4 \quad$ Vorbereitung des Pflanzenmaterials für die PCR 165

2.4.1 Für die normale PCR 165

2.4.2 Für die BIO-PCR 165

$2.5 \quad$ Molekulargenetische Methoden 166

2.5.1 Sterilisation von Geräten und Lösungen 166

2.5.2 Stammlösungen und Puffer 166

2.5.3 DNA-Extraktion (nach KRÄMER et al., 1998) 167

2.5.4 Agarose-Gelelektrophorese 167

2.5.5 Ethidiumbromid-Färbung und Fotografie der Gele 168

$\begin{array}{lll}\text { 2.5.6 Polymerase-Kettenreaktion (PCR) } & 168\end{array}$

$\begin{array}{ll}3 & \mathbf{1 7 0}\end{array}$

3.1 DNA-Extraktion (wie in 2.5.3 beschrieben) 170

$\begin{array}{lll}\text { 3.1.1 Aus Bakterienreinkulturen } & 170\end{array}$

3.1.2 PCR-Nachweis der Bakterien in planta 170

3.2 Nachweisgrenze von $X c p$-Reinkulturen durch die PCR 170

3.3 In planta-Nachweis von Xcp durch die PCR 171

$3.4 \quad$ BIO-PCR 172

3.4.1 BIO-PCR von Xcp nach Vorkultur von Pelargonienstengel-Scheibchen 172 zusammen mit Bakteriensuspension in TC-Lösung

3.4.2 BIO-PCR von Xcp in planta fast 4 Jahre nach Inokulation 174

3.4.3 Nachweis von Xcp in planta durch Homogenisation oder die Scheib- 176 chen-Methode

3.5 Eignung der Primer zum Nachweis verschiedener Xcp-Stämme $\quad 177$

3.6 Prüfung der Primer auf Kreuzreaktion mit anderen Bakterienarten und 178 Xanthomonas campestris Pathovarietäten 
4.1 Vergleich der verschiedenen Primer 181

4.2 Vergleich der DNA-Extraktion oder des Bakterienaufschlusses bei ver- 182 schiedenen Verfahren

4.3 Nachweisempfindlichkeit 183

$\begin{array}{lll}4.4 & \text { Kreuzreaktionen } & 186\end{array}$

$4.5 \quad$ Vergleich verschiedener $X c p$-Stämme 187

4.6 Vor- und Nachteile der in dieser Arbeit eingesetzten Primer und Ex- 187 traktionsmethode gegenüber den anderen publizierten Verfahren

4.7 Einsatz der PCR für Routine-Tests, Vor- und Nachteile gegenüber an- 188 deren Methoden

$5 \quad$ ZUSAMMENFASSUNG 
Abkürzungsverzeichnis

$$
\mu
$$$$
\%
$$

${ }^{\circ} \mathrm{C}$

$\mu 1$

Abb.

a. dest.

AK

AluI

AP

Bakt.

BAZ

BBA

Bidest.

bp

\section{BSA}

bzw.

ca.

cfu

$\mathrm{cm}$

CS-Medium

d

d. h.

DAS-ELISA

\section{DNA}

dNTP

DSM

E

$\mathrm{E}_{405 \mathrm{~nm}}$

EDTA

ELISA

EPPO

et al.

etc.

ET-Medium

$\mathrm{EtOH}$

EU

Fa.

FITC

GSPB

$\mathrm{h}$

ICMP

IF

IgG

IPO

$\mathrm{KB}$

$\mathrm{kB}$

1

M
Prozent

Grad Celsius

Mikro

Mikroliter

Abbildung

Destilliertes Wasser

Antikörper

Enzym von Arthrobacter luteus

alkalische Phosphatase

Bakterien

Bundesanstalt für Züchtungsforschung an Kulturpflanzen

Biologische Bundesanstalt für Land- und Forstwirtschaft zweifach destilliert

Basenpaare

Rinderserumalbumin

beziehungsweise

circa

colony forming units, Lebendkeimzahl

Zentimeter

Cellobiose-Stärke-Medium

Tag

das heißt

Double Antibody Sandwich-ELISA

Desoxyribonukleinsäure

Desoxynukleotid-5 '-Triphosphat

Deutsche Sammlung von Mikroorganismen

Extinktion

Extinktion bei einer Wellenlänge von $\lambda=405 \mathrm{~nm}$

Ethylendiamintetraessigsäure

enzyme-linked immunosorbent assay

European Plant Protection Organization

et alii ( $=$ und andere)

et cetera

Esculin-Trehalose-Medium

Ethanol

Europäische Union

Firma

Fluoreszein-Isothiocyant

Göttinger Sammlung Phytopathogener Bakterien

Stunde

International Collection of Micro-organisms from Plants

Immunfluoreszenz

Immunglobulin $\mathrm{G}$

Instituut voor Plantenziektenkundig Onderzoek, Niederlande

King B-Medium

Kilobasen

Liter

Mol pro Liter, molar 
mg

$\min$

$\mathrm{ml}$

NCPPB

NGA

NGAR

NGAS

NGASR

N. Kont.

NB-Lösung

n. g.

$\mathrm{nm}$

$\mathrm{Nr}$.

n. u.

$\varnothing$

OD

P. Kont.

PBR322

PBS

PCR

Pfl.

$\mathrm{pH}$

pmol

pNPP

ppm

pv.

PVP

$\mathrm{R}$

rpm

$\mathrm{S}$

$\mathrm{T}$

TC-Lösung

TC-Medium

Tab.

Taq

TBE

TE

TRIS

TTC

$\mathrm{U}$

u. W.

$\mathrm{U} / \mathrm{min}$

UPM

UV

$\mathrm{V}$

WR

Xcp
Milligramm

Minuten

Milliliter

National Collection of Plant Pathogenic Bacteria

Nutrient+Glucose-Agar

$\mathrm{NGA}+$ Rifampicin

NGA+Streptomycin

$\mathrm{NGA}+$ Rifampicin + Streptomycin

Negativ-Kontolle

Nutrient Broth-Lösung

nicht gefunden

Nanometer

Nummer

nicht untersucht

Durchmesser, im Durchschnitt

optische Dichte

Positiv-Kontrolle

Plasmid BR322

phosphate buffered saline $=$ Phosphat-gepufferte

physiologische Kochsalzlösung

polymerase chain reaction

Pflanze

negativer dekadischer Logarithmus der $\mathrm{H}^{+}$-Konzentration

Picomol

4-Nitrophenylphosphat

parts per million (Teile auf eine Million)

Pathovar

Polyvinylpyrrolidon

Rifampicin

Umdrehungen pro Minute

Streptomycin

Tween

Tween-Cellobiose-Lösung

Tween-Cellobiose-Medium

Tabelle

Thermus aquaticus

Tris-boric-acid EDTA

Tris-EDTA

Tris-(Hydroxymethyl)-Aminomethan

Triphenyltetrazoliumchlorid

Unit (Einheit der Enzymaktivität)

unseres Wissens

Umdrehungen pro Minute

Umdrehungen pro Minute

Ultraviolett

Volt

Wiederfindungsrate

Xanthomonas campestris pv. pelargonii 
KAPITEL I

ENTWICKLUNG SEMISELEKTIVER MEDIEN FÜR XANTHOMONAS CAMPESTRIS PV. PELARGONII, DEN ERREGER DER STENGELFÄULE UND BLATTFLECKENKRANKHEIT VON PELARGONIEN

\section{EINLEITUNG}

Das Bakterium Xanthomonas campestris pv. pelargonii (Xcp) (BROWN) DYE 1978 ruft an den heute im Zierpflanzenbau verwendeten Sorten von Pelargonium zonale- und Pelargonium peltatum-Hybriden die gefürchtete und wirtschaftlich bedeutendste Krankheit dieser Kultur, die bakterielle Welke, Blattfleckenkrankheit und Stengelfäule, hervor (PAGEL, 1993).

Die erste Beschreibung der Krankheit stammt wahrscheinlich von LEQUET (1888), und STONE und SMITH (1898) detektierten als erste Bakterien im infizierten Gewebe. Die Benennung des Erregers der bakteriellen Stengelfäule und Blattfleckenkrankheit änderte sich seit der ersten detaillierten Abhandlung über diese Krankheit in den USA (BROWN 1923) im Laufe der Jahre mehrfach.

Folgende Synonyme wurden verwendet:

Bacterium pelargonii, Pseudomonas pelargonii, Phytomonas pelargonii, Bacterium geranii, Pseudomonas geranii, Xanthomonas geranii (BRADBURY 1986). Von VAUTERIN et al. (1995) wurde die Bezeichnung Xanthomonas hortorum pv. pelargonii vorgeschlagen, welche wiederum von SCHAAD et al. (2000) in Xanthomonas hederae pv. pelargonii geändert wurde. Da bisher noch keine endgültige Übereinkunft erzielt worden ist (YOUNG et al., 2001), wird in dieser Arbeit die lange akzeptierte Bezeichnung Xanthomonas campestris pv. pelargonii beibehalten.

Xcp wird innerhalb der Abteilung „Bacteria“ der Gruppe der Gram-negativen, aeroben Stäbchen und Coccen, der Familie Pseudomonadaceae, Gattung Xanthomonas zugeteilt (BUCHANAN und GIBBONS, 1974). Der Erreger ist polar monotrich, ein gerades Stäbchen von 1 - 1,5 $\mu \mathrm{m}$ Länge und 0,5 - 0,7 $\mu \mathrm{m}$ Breite. Das Wachstumsoptimum liegt bei 28 $30{ }^{\circ} \mathrm{C}$, das Wachstumsminimum bei $1^{\circ} \mathrm{C}$. Der thermale Tötungspunkt liegt bei 51,5 - 55 
${ }^{\circ} \mathrm{C}$ (MUNNECKE, 1954; KLEINHEMPEL et al., 1989). Nach MUNNECKE (1954) wird der Erreger nach 3-monatigem Gefrieren bei $-7{ }^{\circ} \mathrm{C}$ nicht abgetötet und verliert nicht seine Pathogenität. Säure aber kein Gas wird von Glucose, Mannose, Galaktose, Fruktose, Laktose, Saccharose und Cellobiose gebildet. Stärke wird verwertet, aber langsam (NAMETH et al., 1999). Das langsame Wachstum auf Stärke- und Fleischextrakt-Agar und die schwach gelbe Kolonien-Färbung erleichtern die Unterscheidung von $X c p$ von anderen Xanthomonaden, die auf Pelargonien als Saprophyten vorkommen können. Das Bakterium kann Nitrat nicht reduzieren (KLEINHEMPEL et al., 1989) und die Toleranz für Triphenyltetrazoliumchlorid liegt bei 0,01\% (BRÖTHER 1981b).

$X c p$ ist weltweit in fast allen Ländern von Bedeutung, in denen Pelargonien wachsen, und kann besonders dann zu beachtlichen Verlusten (über 50\%) führen, wenn der Erreger über stecklingsvermehrte Pflanzen verbreitet wird. Eine Übertragung erfolgt ferner mit Samen, Meristemkulturen, Insekten oder Komposterde (WÖLK \& SARKAR, 1994; STEPHENS and TUNIER, 1989; GRIESBACH et al., 1985). In luftgetrockneten Blättern auf der Bodenoberfläche von Gewächshäusern kann Xcp mehr als 200 Tage infektiös bleiben (KENNEDY et al., 1987).

Zur Bekämpfung von Phytobakteriosen gibt es bisher nur wenige wirksame Pflanzenschutzmittel, wie z. B. Kupfersulfat (FLAHERTY et al., 2001). Spritzungen mit Antibiotika sind in vielen Ländern Westeuropas, u. a. in Deutschland, aus medizinisch toxikologischen Gründen nicht zugelassen und wegen der möglichen Entwicklung resistenter Stämme auch nicht sinnvoll (SCHAFFER \& GOODMAN, 1985). Dies gilt auch für Xcp. Deswegen kann diese Krankheit effektiv nur durch strenge pflanzenhygienische Maßnahmen bekämpft werden. Der Erfolg dieser Strategie ist ganz wesentlich davon abhängig, dass hochempfindliche Nachweismethoden zur Verfügung stehen.

Probleme beim Nachweis ergeben sich aus dem latenten Vorkommen der Bakterien in symptomlosen Pflanzen, der ungleichen Verteilung der Erreger in der Pflanze, Kreuzreaktionen mit anderen pathogenen und nicht pathogenen Endophyten sowie aus unterschiedlichen Nachweisgrenzen verschiedener Diagnoseverfahren. Die meisten Nachweisverfahren (serologische und molekulargenetische Methoden) für phytopathogene Bakterien besitzen eine Empfindlichkeit, die oft nicht unter 1000 Keimen/ml (Kapitel III und IV) liegt.

Für eine erfolgreiche Elimination des Krankheitserregers aus Pelargonienkulturen werden jedoch sehr empfindliche Nachweismethoden benötigt, da z. B. auch bei der Meristemspit- 
zenkultur die latente Besiedlung des Gewebes durch Xcp zunächst unerkannt bleiben kann (CLARKE und ADAMS, 1977; REUTHER, 1988).

Die empfindlichste und überdies sicherste Methode ist immer noch die Isolation der gesuchten Bakterien aus dem befallenen Pflanzenmaterial mit Hilfe selektiver Nährmedien. Ein Ziel der vorliegenden Arbeit war deswegen die Entwicklung oder Verbesserung von semiselektiven Nährmedien für Xcp. Ein semiselektives Medium sollte eine gute Wachstumseffizienz für das Zielbakterium besitzen und neben einer hohen Selektivität auch eine gute Differenzierbarkeit der gesuchten Kolonien von den jenigen der Kontaminanten erlauben.

Bereits 1993 wurde in Göttingen ein Selektivmedium für Xcp entwickelt (BATUR et al., 1993; BATUR, 1994), das eine frühzeitige und sichere Befallsdiagnose gewährleistete.

Dieses sogenannte Tween-Cellobiose-Medium wurde überprüft und in vorliegender Arbeit noch weiter verbessert. Außerdem wurde ein alternatives semiselektives Medium entwickelt, das in der Handhabung einfacher ist. 


\section{MATERIAL UND METHODEN}

\subsection{Herkunft der Bakterien}

Die in der vorliegenden Arbeit verwendeten Bakterienstämme stammen aus der „Göttinger Sammlung Phytopathogener Bakterien“ (GSPB) und sind in Tab. 1 aufgelistet.

Tab. 1: Verwendete Bakterienstämme

\begin{tabular}{|c|c|c|}
\hline Art & GSPB-Nr. & Herkunft \\
\hline Xanthomonas campestris pv. pelargonii & 191 & $\begin{array}{l}\text { DSM 50857, isol. von Stolp aus } \\
\text { Pelargonium zonale }\end{array}$ \\
\hline Xanthomonas campestris pv. pelargonii & 197 & $\begin{array}{l}\text { DSM 50858, isol. von Stolp aus } \\
\text { Pelargonium peltatum }\end{array}$ \\
\hline Xanthomonas campestris pv. pelargonii & 203 & $\begin{array}{l}\text { DSM 50859, isol. von Sauthoff } \\
\text { aus Pelargonium zonale (Nr. } \\
\text { 1248/9), BBA, Berlin }\end{array}$ \\
\hline Xanthomonas campestris pv. pelargonii & 1955 & $\begin{array}{l}\text { isol. von Pagel, Fa. Endisch, } \\
1990\end{array}$ \\
\hline Xanthomonas campestris pv. pelargonii & 1957 & $\begin{array}{l}\text { isol. von Wohanka, Geisen- } \\
\text { heim, } 1990\end{array}$ \\
\hline Xanthomonas campestris pv. pelargonii & 2104 & $\begin{array}{l}\text { G-4428, aus Pelargonium zona- } \\
\text { le, Dresden, } 1992\end{array}$ \\
\hline Xanthomonas campestris pv. pelargonii & 2105 & $\begin{array}{l}\text { G-4429, aus Pelargonium zona- } \\
\text { le, Dresden, } 1992\end{array}$ \\
\hline Xanthomonas campestris pv. pelargonii & 2503 & $\begin{array}{l}\text { resistent gegen } 100 \text { ppm Rifam- } \\
\text { picin, gewonnen von Batur- } \\
\text { Michaelis aus GSPB 1955, Göt- } \\
\text { tingen, } 1996\end{array}$ \\
\hline Xanthomonas campestris pv. pelargonii & 2513 & E-29, Hannover, 1993 \\
\hline Xanthomonas campestris pv. pelargonii & 2514 & $\begin{array}{l}\text { isol. von Brielmaier-Liebetanz, } \\
\text { (Nr. 1586), BBA, Braun- } \\
\text { schweig, 1997 }\end{array}$ \\
\hline Xanthomonas campestris pv. pelargonii & 2630 & isol. von Berkelmann, (Nr. 31- \\
\hline
\end{tabular}




\begin{tabular}{|l|l|l|}
\hline Art & GSPB-Nr. & Herkunft \\
\hline Xanthomonas campestris pv. pelargonii & 2632 & $\begin{array}{l}\text { E), Geisenheim, 1993 } \\
\text { isol. von Berkelmann, (Nr. 54- } \\
\text { E), Geisenheim, 1995 }\end{array}$ \\
\hline Xanthomonas campestris pv. pelargonii & 2634 & $\begin{array}{l}\text { isol. von Berkelmann, (Nr. 59- } \\
\text { E), Geisenheim, 1995 }\end{array}$ \\
\hline Xanthomonas campestris pv. pelargonii & 2638 & $\begin{array}{l}\text { isol. von Berkelmann, (Nr. 66 } \\
\text { E), Geisenheim, 1995 }\end{array}$ \\
\hline Xanthomonas campestris pv. pelargonii & 2640 & $\begin{array}{l}\text { isol. von Berkelmann, (Nr. 68- } \\
\text { E), Geisenheim, 1995 }\end{array}$ \\
\hline Xanthomonas campestris pv. pelargonii & 2642 & $\begin{array}{l}\text { isol. von Berkelmann, (Nr. 70- } \\
\text { E), Geisenheim, 1995 }\end{array}$ \\
\hline Erwinia herbicola & & $\begin{array}{l}\text { NCPPB 601, isol. aus Apfel, } \\
\text { England, 1958 }\end{array}$ \\
\hline Pseudomonas syringae pv. syringae & 1004 & $\begin{array}{l}\text { isol. von Mavridis, aus Flieder, } \\
\text { Göttingen, 1980 }\end{array}$ \\
\hline Pseudomonas fluorescens & 450 & \begin{tabular}{l} 
G-1 \\
\hline
\end{tabular} \\
\hline
\end{tabular}

\subsection{Medienvergleich}

Folgende Medien wurden für die Isolierung von Xcp überprüft: SMB-Medium (PALLERONI \& DOUDOROFF, 1972), XTS-Medium (SCHAAD \& FORSTER, 1985), KM-1Medium (KIM et al., 1982), MXP-Medium (CLAFLIN et al., 1987), CS-Medium (NORMAN \& ALVAREZ 1989), ET-Medium (NORMAN \& ALVAREZ, 1989), BSCAAMedium (RANDHAWA \& SCHAAD, 1987), MSP-Medium (MOHAN \& SCHAAD, 1987), WBC- Medium (DUVEILLER, 1989), MD5-Medium (KUAN et al., 1985), TweenMedien (McGUIRE, JONAS \& SASSER, 1986) für die Isolierung von Xcp angesetzt. Die Herstellung der getesteten Medien erfolgte nach den Angaben in der Literatur und ist bei BATUR (1994) ausführlich beschrieben. 


\subsection{Verbesserung eines semiselektiven Nährmediums für Xcp}

Das von BATUR et al. (1993) und BATUR (1994) entwickelte Tween+CellobioseMedium wurde weiter verbessert.

\subsubsection{Bakterienvorkultur}

Die bei der Prüfung verwendeten Bakterienstämme waren hauptsächlich der Xcp Stamm GSPB 2503, der P. syringae Stamm GSPB 1004, der P. fluorescens Stamm GSPB 1714 und der Erwinia herbicola Stamm GSPB 450. Die Xcp-Stämme wurden zunächst auf NGA und danach auf Rhodes-Nähragar kultiviert, während die Anzucht von P. syringae, P. fluorescens und Erwinia herbicola auf dem King B-Nähragar erfolgte.

NGA-Medium (nach MAVRIDIS)

Nutrient broth (Difco oder Oxoid) $8,0 \mathrm{~g}$

Glucose $10,0 \mathrm{~g}$

Hefeextrakt $3,0 \mathrm{~g}$

Agar $16,0 \mathrm{~g}$

$\mathrm{H}_{2} \mathrm{O}$ bidest. $1000 \mathrm{ml}$

$\mathrm{PH}$ 7,2

RHODES-Medium (nach RHODES, 1959)

Pepton

Hefeextrakt

$\mathrm{NaCl}$

Agar

$\mathrm{H}_{2} \mathrm{O}$ bidest.

$\mathrm{PH}$

KING's B-Medium (KING et al., 1954)
$10,0 \mathrm{~g}$

$3,0 \mathrm{~g}$

$5,0 \mathrm{~g}$

$15,0 \mathrm{~g}$

$1000 \mathrm{ml}$

7,2

Proteose-Pepton (Difco) $20,0 \mathrm{~g}$

$\mathrm{K}_{2} \mathrm{HPO}_{4}$ $1,5 \mathrm{~g}$

$\mathrm{MgSO}_{4} \mathrm{X} 7 \mathrm{H}_{2} \mathrm{O}$ $1,5 \mathrm{~g}$ 


$\begin{array}{ll}\text { Glycerin } & 10 \mathrm{ml} \\ \text { Agar } & 15,0 \mathrm{~g} \\ \mathrm{H}_{2} \mathrm{O} \text { bidest. } & 1000 \mathrm{ml} \\ \mathrm{PH} & 7,2\end{array}$

Dieses Medium wurde als Vergleichsmedium für die Kultivierung der Pseudomonas spp. benutzt.

\subsubsection{Prüfung der semiselektiven Medien}

Aus den frischen Bakterienkulturen wurden Suspensionen in 0,01 $\mathrm{M} \mathrm{MgSO}_{4}$-Lösung angesetzt und auf eine optische Dichte von 0,06 bei $660 \mathrm{~nm}$ Wellenlänge eingestellt. Von dieser Ausgangkonzentration wurde eine 7-stufige Verdünnungsreihe hergestellt. Aus den Verdünnungsstufen $10^{-5}, 10^{-6}$ und $10^{-7}$ wurden jeweils $0,1 \mathrm{ml}$ auf drei Petrischalen der einzelnen zu testenden Nährmedien ausgestrichen. Die Petrischalen wurden bei $29{ }^{\circ} \mathrm{C}$ im Brutschrank inkubiert.

Nach 4 - 5 Tagen bei den semiselektiven Medien und nach 2 Tagen bei den Standardmedien (NGA und King B) wurde die Lebendzellzahl je ml (cfu/ml) durch Auszählung der gebildeten Kolonien bestimmt.

Außerdem wurde die Selektivität bestimmt. Sie gibt den Anteil der gewachsenen Kolonien des Zielbakteriums auf dem geprüften Medium an, wenn Xcp mit einem Gemisch anderer Bakterien ausgebracht wurde. Die Selektivität wurde in Prozent ausgedrückt und nach folgender Formel bestimmt:

$$
\text { Selektivität (\%) }=\frac{\text { Summe der Kolonien des Zielbakteriums auf Medium A X } 100}{\text { Summe aller Kolonien auf dem Medium A }}
$$

Weiter wurde der phänotypische Charakter (Form, Farbe, Konsistenz, Größe) der auf dem geprüften Medium gewachsenen Kolonien eines jeden Bakterienstammes genau erfasst.

Die Medien, die ein gutes Wachstum von Xcp-Stämmen erlaubten und andere saprophytische Bakterien unterdrückten, wurden durch Zugabe verschiedener Antibiotika abgeändert, um ihre Selektivität und Differentialität weiter zu verbessern. 


\section{ERGEBNISSE}

\subsection{Vergleich diverser semiselektiver Nährmedien}

Zunächst wurde überprüft, inwieweit diverse selektive Nährmedien das Wachstum von Xсp im Vergleich mit verschiedenen Kontaminanten erlaubten. Von jedem Bakterienstamm wurde eine Suspension der $\mathrm{OD}_{660 \mathrm{~nm}}=0,06$ hergestellt und eine 1/10 Verdünnungsreihe in 0,01 M Magnesiumsulfat angelegt. Von den Verdünnungsstufen $10^{-4}, 10^{-5}$ und $10^{-6}$ wurden jeweils 0,1 ml auf Petrischalen mit den verschiedenen Nährböden gleichmäßig verteilt. Nach 3 - 7 Tagen wurden die Kolonien gezählt, und aus den Mittelwerten die theoretische Bakterienkonzentration in der Ausgangssuspension berechnet (Tab. 2).

Tab. 2: Ermittlung der theoretischen Bakterienzahl in $1 \mathrm{ml}$ Suspension mit einer optischen Dichte von 0,06 nach Ausplattieren auf verschiedenen Nährmedien

\begin{tabular}{|c|c|c|c|c|c|}
\hline Medum & $\begin{array}{l}\text { Xсp } \\
\text { GSPB } 203\end{array}$ & $\begin{array}{l}\text { Хсp } \\
\text { GSPB } 1955\end{array}$ & $\begin{array}{l}\text { P. fluor. } \\
\text { GSPB } 1714\end{array}$ & $\begin{array}{l}\text { P. syr. } \\
\text { GSPB } 1004\end{array}$ & $\begin{array}{l}\text { E. herb. } \\
\text { GSPB } 450\end{array}$ \\
\hline XTS & $3 \times 10^{8}$ & $6,3 \times 10^{7}$ & $9,3 \times 10^{7}$ & $2 \times 10^{8}$ & $1,6 \times 10^{7}$ \\
\hline $\mathrm{XTS}+\mathrm{V}^{1)}$ & $\mathrm{nd}^{2)}$ & $3 \times 10^{8}$ & $8 \times 10^{8}$ & $8 \times 10^{8}$ & ng \\
\hline KM-1 & $6 \times 10^{7}$ & $4 \times 10^{7}$ & $1 \times 10^{7}$ & $2 \times 10^{8}$ & ng \\
\hline $\mathrm{KM}-1+\mathrm{V}$ & $6 \times 10^{8}$ & $(+)$ & $8 \times 10^{8}$ & $(+)$ & ng \\
\hline MXP & $(+)$ & $(+)$ & $2 \times 10^{9}$ & $1 \times 10^{9}$ & ng \\
\hline CS & $9 \times 10^{8}$ & $1 \times 10^{7}$ & $7 \times 10^{8}$ & $4 \times 10^{8}$ & ng \\
\hline ET & $7 \times 10^{8}$ & $1 \times 10^{7}$ & $7 \times 10^{8}$ & $(+)$ & ng \\
\hline MSP & + & + & + & + & $(+)$ \\
\hline BSCAA & $(+)$ & $(+)$ & $(+)$ & + & + \\
\hline WBC & $n z^{3)}$ & ng & nd & nd & nd \\
\hline MD5 & $2 \times 10^{7}$ & $3 \times 10^{7}$ & $(+)$ & $(+)$ & $7 \times 10^{7}$ \\
\hline $\mathrm{MD} 5+\mathrm{A}^{4)}$ & $7 \times 10^{7}$ & $2 \times 10^{8}$ & $2 \times 10^{8}$ & $2 \times 10^{9}$ & $\mathrm{ng}^{5)}$ \\
\hline Tween A & $4 \times 10^{8}$ & $7 \times 10^{7}$ & $(+)$ & ng & ng \\
\hline Tween B & $4 \times 10^{8}$ & $8 \times 10^{7}$ & ng & ng & ng \\
\hline Tween C & $4 \times 10^{8}$ & $6 \times 10^{7}$ & ng & ng & ng \\
\hline
\end{tabular}


1) V: $10 \mathrm{mg} / \mathrm{l}$ Vancomycin

2) nd: nicht durchgeführt

3) nz: nicht zählbare kleine $X c p$ Kolonien

4) A: $0,4 \mathrm{mg} / \mathrm{ml}$ Aztreonam

5) ng: nicht gewachsen

6) $(+)$ : sehr schwach gewachsen

7) +: gewachsen (direkter Ausstrich)

SCHAAD und FORSTER (1985) entwickelten das XTS-Medium für die Isolierung von Xanthomonas campestris pv. translucens, ein phytopathogenes Bakterium an Weizen. Die Kolonien der untersuchten Stämme von Xcp (GSPB 1955 und 203) waren nach 4 Tagen Inkubation bei $29^{\circ} \mathrm{C}$ auf diesem Medium rund, konvex, gelb, glänzend und 3 - $5 \mathrm{~mm}$ im Durchmesser. Nach 7 Tagen hatten die Kolonien einen Durchmesser von 7 mm. Das Wachstum von Xcp auf dem XTS-Medium war genauso gut wie auf dem nicht selektiven NGA-Medium. Aber auch die Kontaminanten wurden nicht gehemmt.

Auf dem XTS-Medium mit dem Antibiotikum Vancomycin wuchsen die Bakterien $X c p$, $P$. fluorescens und $P$. syringae etwas schneller und bildeten mehr Kolonien als auf dem XTS-Medium ohne das Antibiotikum. Vancomycin wirkt toxisch auf die meisten Grampositiven Bakterien (LANCANI und PARANTI, 1982). E. herbicola zeigte nach Vancomycinzugabe auf diesem Medium kein Wachstum.

KIM (1982) entwickelte das semiselektive Medium KM-1, das für die Isolation von Xanthomonas campestris pv. translucens vor allem bei Bodenproben eingesetzt wurde. Auf diesem Medium konnten die Kolonien des Xcp-Stammes GSPB 203 bereits nach 3 Tagen Inkubation bei $29{ }^{\circ} \mathrm{C}$ ausgezählt werden. Nach sechs Tagen waren die Kolonien darauf rundlich, glänzend, konvex und beige bis dunkelorange in der Farbe. Die Koloniendurchmesser lagen zwischen 1 - 5 mm. Kolonien mit einem Durchmesser von 5 mm waren dunkler als die kleineren. Auch der Xcp-Stamm GSPB 1955 verhielt sich auf KM-1 ähnlich wie GSPB 203 mit dem einzigen Unterschied, dass seine Kolonien in der Mitte rötlich und am Rand heller waren. Der Kontaminant E. herbicola wurde total gehemmt, aber nicht die beiden Pseudomonaden. 
Durch die Zugabe von 10 mg/ml Vancomycin zum KM-1-Medium wurde versucht, das Wachstum von $P$. fluorescens zu unterdrücken. Leider zeigte sich dadurch auch eine Wachstumshemmung der beiden Xcp-Stämme. Während die Kolonien von GSPB 203 rund, konvex, rötlich und meist nur 1 - 3 mm groß waren, waren die Kolonien von GSPB 1955 auch nach 7 Tagen Inkubation noch sehr klein (pünktchenförmig). Auch bei P. fluorescens wurde eine Wachstumshemmung durch die Vancomycinzugabe verursacht (die Kolonien waren nur 0,5 - 1 mm groß), die Kolonienzahl blieb aber unverändert. Sie besaßen einen hellen Rand und waren zur Mitte hin rötlich. $P$. syringae bildete zahlreiche, aber sehr kleine Kolonien, während E. herbicola nicht wuchs.

CLAFLIN, VIDAVER und SASSER (1987) entwickelten für Xanthomonas campestris pv. phaseoli das semiselektive MXP-Medium. Auf diesem Medium bilden die Bakterien bei Stärkeverwertung um die Kolonien herum eine durchsichtige Zone. Alle 5 getesteten XcpStämme (197, 203, 1955, 1957, 2104) wuchsen jedoch ohne Zonenbildung und recht langsam. Das Unterbleiben der Zonenbildung beruhte wahrscheinlich auf ihrer Unfähigkeit zum Stärkeabbau. Nach 7 Tagen bei $29^{\circ} \mathrm{C}$ waren die Kolonien rund, konvex, glänzend, cremefarben und am Rand etwas schleimig. Der Koloniedurchmesser lag zwischen 1 - 5 $\mathrm{mm}$.

NORMAN und ALVAREZ (1989) entwickelten für Xanthomonas campestris pv. dieffenbachiae das selektiv wirkende CS-Medium. Nach 4 Tagen Bebrütung bei $29{ }^{\circ} \mathrm{C}$ waren die getesteten Xcp-Stämme 203 und 1955 gut gewachsen, obwohl Xcp-Stämme Stärke nur langsam verwerten können. Nach 9 Tagen Inkubation lag der Koloniedurchmesser von Stamm 203 bei 5 - 6 mm und der von Stamm 1955 bei 5 - 8 mm. Allerdings war die Kolonienzahl vom Stamm 1955 reduziert. Auf diesem Medium erscheinen die X. pelargoniiKolonien rund, konvex und schleimig. Die Zugabe von 0,001\% TTC gab den Bakterienkolonien ein charakteristisches Aussehen. Die Kolonien waren cremefarben mit einem roten Zentrum. Allerdings zeigten die Kolonien dieses Erscheinungsbild nur dann, wenn die Petrischalen einen relativ schwachen Kolonienbesatz aufwiesen.

Auch das ET-Medium wurde für die Isolierung von Xanthomonas campestris pv. dieffenbachiae durch NORMAN und ALVAREZ (1989) entwickelt. Auf diesem Medium wuchsen beide $X c p$-Stämme langsam und blieben klein. Der Stamm 1955 bildete um seine Ko- 
lonien herum durch die Hydrolyse von Äskulin eine braune Zone. Diese Kolonien waren nach 4 Tagen bei $29{ }^{\circ} \mathrm{C}$ nur so groß wie ein kleiner Punkt, rund und dunkelbraun. Der Stamm GSPB 203 färbte das Medium so stark braun, dass die Erkennung der Kolonie erheblich erschwert wurde.

Das von MOHAN und SCHAAD (1987) entwickelte MSP-Medium wurde mit Erfolg für die selektive Isolierung von $P$. syringae pv. phaseolicola eingesetzt. Durch die Zugabe von Cycloheximid wurde jegliches Pilzwachstum unterdrückt. Die Verwendung des pHIndikators Bromthymolblau erleichterte nach Verwendung der Saccharose mit gleichzeitiger Säureproduktion die Koloniendifferenzierung. Nach 5 Tagen Kultivierung bei $29{ }^{\circ} \mathrm{C}$ auf MSP waren die Kolonien von X. pelargonii (GSPB 203 und 1955) konvex, rund und gelb, mit einem Durchmesser von 2 mm. Leider wuchsen auch die geprüften Epiphyten auf dem MSP-Medium gut.

Das für Xanthomonas campestris pv. campestris entwickelte BSCAA-Medium (RANDHAWA und SCHAAD, 1984) erwies sich für X. pelargonii schlecht geeignet. Alle fünf getesteten Isolate von $X$. pelargonii (GSPB 197, 203, 1955, 1957, 2104) konnten darauf nur sehr schwach wachsen, weil sie unfähig sind, Stärke zu verwerten. Die Kolonien erreichten im Durchschnitt nach 6 Tagen bei $29^{\circ} \mathrm{C}$ einen Durchmesser von 0,5 mm, sie waren rund und weißlich.

DUVEILLER (1989) entwickelte das WBC-Medium für die Isolierung von Xanthomonas campestris pv. translucens. Dieses Nährmedium erlaubte dem Xcp-Stamm 203 nur ein sehr schwaches Wachstum mit der Bildung von kleinen, runden, glänzenden Kolonien, während Stamm 1955 darauf nicht wachsen konnte.

KUAN (1985) entwickelte das MD5-Medium für die Isolierung Xanthomonas campestris pv. carotae. Auf diesem Medium wuchsen die beiden Xcp-Stämme 203 und 1955 ziemlich gut. Die Kolonien waren nach 7 Tagen rund, konvex, gelblich bis gelb und 1 - 2 mm im Durchmesser. Nach 12 Tagen Wachstum schwankte die Koloniengröße relativ stark (4 - 8 mm Durchmesser), und ihre Farbe war in Abhängigkeit von Stamm und Alter gelblich bis deutlich gelb. Auch E. herbicola wuchs darauf gut, während $P$. fluorescens und $P$. syringae 
nur schwach wuchsen. Nach Zugabe von 0,4 mg/ml des Antibiotikums Aztreonam wurde E. herbicola total gehemmt.

Die Selektivität der von McGUIRE et al. (1986) für die Isolierung von Xanthomonas campestris pv. vesicatoria aus infizierten Tomatenpflanzen sowie verseuchten Böden entwickelten Tween-Medien beruht auf dem Gehalt an Borsäure und den vier Antibiotika Cefalexin, 5-Fluorouracil, Tobramycin und Cycloheximid. Eine totale Eliminierung von Kontaminanten wird dabei allerdings nicht erreicht.

Die getesteten $X c p$-Stämme wuchsen auf allen drei Varianten A, B und C des TweenMediums relativ gut. Jedoch variierte die Wachstumsgeschwindigkeit unter den drei Medienmodifikationen zum Teil beträchtlich. Am langsamsten wuchsen die Bakterien auf C und am schnellsten auf A. Der Hauptgrund für diesen Wachstumsunterschied ist in erster Linie auf die unterschiedlichen Konzentrationen der Borsäure und weniger auf die der Antibiotika zurückzuführen.

Die Xcp-Kolonien erschienen auf diesen Medien (A, B, C) nach 10 Tagen Inkubation bei $29^{\circ} \mathrm{C}$ rund, gelb, glänzend, schwach erhaben, mit einem Durchmesser von maximal $2 \mathrm{~mm}$. Auffallend war dabei die Bildung eines Hofes um die Kolonien herum, der auf die Lipaseaktivität und damit den Abbau von Tween 80 zurückzuführen ist. Auf allen drei Medien wuchsen $P$. syringae und E. herbicola nicht, während $P$. fluorescens lediglich auf Tween A schwach wachsen konnte.

\subsection{Modifikationen mit dem MD5-Medium}

Weil auf dem MD5-Medium die Xcp-Kolonien gut identifizierbar waren, wurde das Medium modifiziert, um die Wachstumsgeschwindigkeit von Xcp zu fördern und Begleitbakterien entweder absolut unterdrücken oder noch besser differenzieren zu können.

\subsubsection{Wirkung der Borsäure}

Bei allen Borsäurekonzentrationen (0,03 - 0,08\%) wurde der Xcp-Stamm 203 vollständig gehemmt, während Stamm 1955 nur sehr schwach wuchs. Nach 15 Tagen Inkubation entwickelten sich gelbe, runde, konvexe, glänzend kleine Kolonien (Durchmesser 0,5 - 1 mm). Die Kolonienzahl blieb bei allen Borsäurekonzentrationen konstant. Bei 0,08\% Bor- 
säure wurde $X c p$ so stark gehemmt, dass eine Zählung der Kolonien nur schwer möglich war. Borsäure war also, im Unterschied zum Tween-Medium, ungeeignet zur Verbesserung des MD5-Mediums.

\subsubsection{Zugabe von Pepton und Bacitracin}

Bacitracin, im orginalen MD5-Medium enthalten, hemmt die Biosynthese der Bakterienzellwand (OTTEN, 1975) und wirkt hauptsächlich gegen Gram-positive, aber auch gegen einige Gram-negative Bakterien.

Im MD5-Medium bewirkte die Anwesenheit von Bacitracin (10 mg/l) eine Wachstumshemmung von Xcp-Stamm 203, aber nicht von Stamm Xcp 1955. Die geprüften Kontaminanten wurden durch $10 \mathrm{mg} / \mathrm{l}$ Bacitracin nicht gehemmt.

Die Beimischung von 0,5\% Pepton (aus Casein, Fa. Roth) bewirkte bei allen getesteten Bakterienstämmen, auch den Kontaminanten, eine Erhöhung der Kolonienzahl und eine Wachstumsbeschleunigung. So entwickelte der Xcp-Stamm 1955 auf dem peptonhaltigen Medium ohne Bacitracin nach 6 Tagen ca. 5 mm große (mit Bacitracin 3 - 4 mm), runde, konvexe gelbe Kolonien, welche auf dem einfachen MD5-Medium nur als kleine Punkte erkennbar waren.

\subsubsection{Einfluss der Stickstoffzugabe}

Das MD5-Medium wurde mit verschiedenen Konzentrationen der Stickstoffquellen $\mathrm{NH}_{4} \mathrm{Cl}$, $\left(\mathrm{NH}_{4}\right)_{2} \mathrm{SO}_{4}$ und Casaminosäuren kombiniert und ihr Einfluss auf das Bakterienwachstum überprüft.

Die Zugabe von $\mathrm{NH}_{4} \mathrm{Cl}$ rief keine Wachstumsförderung hervor. Eine Konzentration von 0,6\% führte sogar zu einer völligen Wachstumshemmung. Eine Konzentration bis zu 0,2\% von $\left(\mathrm{NH}_{4}\right)_{2} \mathrm{SO}_{4}$ blieb ohne messbaren Einfluss auf $X$. pelargonii, aber bereits $0,4 \%$ $\left(\mathrm{NH}_{4}\right)_{2} \mathrm{SO}_{4}$ hemmte das Bakterienwachstum völlig. Eine Wachstumsförderung, d. h. größere Bakterienkolonien, wurde nur nach Zugabe von Casaminosäuren (Difco, 0,1\%) beobachtet. 


\subsubsection{Einfluss der Zugabe von Aztreonam}

Das Antibiotikum Aztreonam (Aurobindo Pharma Ltd.) wurde in zwei Konzentrationen, 0,4 und 0,8 mg/l, in Kombination mit dem MD5-Medium getestet. Aztreonam (Azactam) unterdrückt vor allem Gram-negative aerobe Bakterien, wie z. B. Pseudomonas aeruginosa (BENITZ und TATRO, 1988) durch Hemmung der Zellwand-Peptidoglycansynthese .

Tab. 3: Einfluss der Zugabe von Aztreonam zum MD5-Medium auf die Anzahl der Kolonien von verschiedenen Bakterien im Vergleich zu den Standardmedien NGA und KB (Effizienz in \%)

\begin{tabular}{l|l|l|l|l|l}
\hline Medien & Xcp 203 & Xcp 1955 & P. fluor.1714 & P. syr. 1004 & E. herb.450 \\
\hline \hline MD5 + 0,4 mg/l & 11 & 47 & 85 & 207 & 0 \\
$\begin{array}{l}\text { Aztreonam } \\
\text { MD5 + 0,8 mg/l } \\
\text { Aztreonam }\end{array}$ & 2 & 35 & 97 & 112 & 0 \\
\hline
\end{tabular}

Die Xcp-Kolonien konnten nach 5 Tagen Wachstum bei $29{ }^{\circ} \mathrm{C}$ gezählt werden. Nach 12 Tagen waren alle Kolonien gelb, rund, konvex, glänzend und ca. 4 mm groß. Die höhere Antibiotikumkonzentration führte zu einer deutlichen Reduktion der Kolonienzahl (Tab. 3). P. fluorescens bildete unterschiedlich große, gelbe Kolonien mit einem sternförmigen Rand. Die Kolonien von $P$. syringae waren flach, rund, hell durchsichtig und ca. 0,5 mm groß, während E. herbicola in beiden Aztreonam-Konzentrationen nicht wachsen konnte. Wegen der guten Differenzierbarkeit wird das mit Aztreonam ergänzte Medium (MD5AMedium) als zur Isolierung von Xcp empfohlen.

Schlussfolgerung: Durch Aztreonam $(0,4 \mathrm{mg} / \mathrm{ml})$ bietet das Medium für $X c p$ ein gutes Wachstum und eine gute Differenzierbarkeit, obwohl $P$. syringae und $P$. fluorescens noch wuchsen, aber auf Grund der Kolonienform sehr leicht differenziert werden konnten. Ein Vorteil war, dass E. herbicola, ein Bakterium das sehr oft bei Pelargonien vorkommt, völlig unterdrückt war. 


\subsubsection{Zusammensetzung des alternativen semiselektiven MD5A-Mediums}

$\begin{array}{ll}\mathrm{K}_{2} \mathrm{HPO}_{4} & 3,0 \mathrm{~g} \\ \mathrm{NaH}_{2} \mathrm{PO}_{4} & 1,0 \mathrm{~g} \\ \mathrm{NH}_{4} \mathrm{Cl} & 1,0 \mathrm{~g} \\ \mathrm{MgSO}_{4} \times 7 \mathrm{H}_{2} \mathrm{O} & 0,3 \mathrm{~g} \\ \text { Bacto Agar } & 17,0 \mathrm{~g} \\ \mathrm{H}_{2} \mathrm{O} \text { bidest. } & 1000 \mathrm{ml} \\ \mathrm{pH} & 7,2\end{array}$

Nach dem Autoklavieren und Abkühlen auf $50{ }^{\circ} \mathrm{C}$ wurden dem Grundmedium folgende sterilfiltrierte Substanzen zugesetzt:

$\begin{array}{ll}\text { Cellobiose } & 10,0 \mathrm{~g} \\ \text { Cycloheximid } & 0,2 \mathrm{~g} \\ \text { L-Glutaminsäure } & 5,0 \mathrm{mg} \\ \text { L-Methionin } & 1,0 \mathrm{mg} \\ \text { Cephalexin } & 10,0 \mathrm{mg} \\ \text { Bacitracin } & 10,0 \mathrm{mg} \\ \text { Aztreonam } & 0,4 \mathrm{mg} \\ \text { Bromthymolblau } & 30,0 \mathrm{mg}\end{array}$

\subsection{Modifikationen des Tween B-Mediums}

Das Tween B-Medium (McGUIRE et al., 1986) wurde modifiziert, um die Wachstumsgeschwindigkeit zu fördern und das karzinogene Antibiotikum 5-Fluorouracil entweder ganz zu vermeiden oder in niedrigeren Konzentrationen einzusetzen.

\subsubsection{Kombination verschiedener C-Quellen}

Wegen des relativ langsamen Wachstums von $X c p$ auf dem originalen Tween-B-Medium wurde versucht, durch Zugabe verschiedener organischer Substanzen als zusätzliche CQuelle die Eigenschaften des Mediums zu verbessern. Zunächst wurden mit Hilfe des Bio- 
log-Systems (BOCHNER, 1989) Verbindungen ermittelt, die von X. pelargonii verwertet werden.

Die Verwertbarkeit dieser Substanzen als einzige C-Quelle wurde in dem Mineralmedium SMB von PALLERONI und DOUDOROFF (1972) vorher überprüft. X. pelargonii wuchs auf dem SMB-Medium mit Galaktose, Fructose, Melibiose, Maltobiose, Bromsuccinat und 2-Oxoglutarsäure, konnte aber Arabinose, Brenztraubensäure (Pyruvat), Methylpyruvat und Methylsuccinat als C-Quelle nicht verwerten.

Tab. 4: Bakterienwachstum (cfu/ml) auf dem Tween B-Medium in Kombination mit verschiedenen organischen Verbindungen (Zugabe von 0,1 ml Bakteriensusupension der OD $=0,06)$

\begin{tabular}{|c|c|c|c|c|}
\hline Nährmedium & Xсp 1955 & P. fluor.1714 & P. syr. 1004 & E. herb. 450 \\
\hline Tween (T) & $1,47 \times 10^{7}$ & $\mathrm{ng}^{1)}$ & ng & ng \\
\hline $\mathrm{T}+1 \%$ Cellobiose & $1,64 \times 10^{7}$ & ng & ng & ng \\
\hline $\mathrm{T}+$ 0,5\% Cellobiose & $2 \times 10^{7}$ & ng & ng & ng \\
\hline $\begin{array}{l}\mathrm{T}+0,5 \% \text { Cellobiose }+ \\
0,5 \% \text { Laktose }\end{array}$ & $1,7 \times 10^{7}$ & ng & ng & ng \\
\hline $\mathrm{T}+1 \%$ Laktose & $1,1 \times 10^{7}$ & ng & ng & ng \\
\hline $\begin{array}{l}\mathrm{T}+0,5 \% \text { Trehalose }+ \\
0,5 \% \text { Laktose }\end{array}$ & $1,72 \times 10^{7}$ & ng & ng & ng \\
\hline $\mathrm{T}+1 \%$ Xylose & $1,9 \times 10^{7}$ & ng & ng & ng \\
\hline $\mathrm{T}+1 \%$ Glukose & $2,1 \times 10^{7}$ & ng & ng & ng \\
\hline $\mathrm{T}+1 \%$ Galaktose & $1,48 \times 10^{7}$ & ng & ng & ng \\
\hline $\mathrm{T}+1 \%$ Saccharose & $1 \times 10^{7}$ & ng & ng & ng \\
\hline $\mathrm{T}+1 \%$ Fruktose & $2 \times 10^{7}$ & ng & ng & ng \\
\hline $\mathrm{T}+1 \%$ Melibiose & $2 \times 10^{7}$ & ng & ng & ng \\
\hline $\mathrm{T}+1 \%$ Arabinose & $1,1 \times 10^{7}$ & ng & ng & ng \\
\hline $\mathrm{T}+$ 0,4 mg/l Aztreonam & $2,2 \times 10^{7}$ & ng & ng & ng \\
\hline $\mathrm{T}+1 \%$ Bromsuccinatsäure & ng & ng & ng & ng \\
\hline
\end{tabular}

1) ng: nicht gewachsen 
Insgesamt wurden 15 verschiedene Verbindungen als zusätzliche Kohlenstoffquelle zu Tween B überprüft (Tab. 4). Von dem Tween B-Medium wurden $100 \mathrm{ml}$ Portionen angesetzt, autoklaviert und bei $55^{\circ} \mathrm{C}$ zu jeder Portion die zusätzliche C-Quelle in 1\%iger Endkonzentration nach Sterilfiltration hinzugefügt. In einigen Fällen wurden Verbindungen miteinander kombiniert. Außer der Kolonienzahl wurden die Wachstumsgeschwindigkeit, Koloniengröße und -farbe geprüft und mit denen von Tween B ohne zusätzliche C-Quelle verglichen. Die Auswertung erfolgte nach 2, 5 und 7 Tagen Inkubation bei $30^{\circ} \mathrm{C}$.

Auf dem nur Tween 80 enthaltenden Medium wurden die Kolonien von $X$. pelargonii bis maximal 2 mm im Durchmesser groß. Durch die Zugabe von Cellobiose, Melibiose, Trehalose sowie Trehalose mit Laktose wurde das Wachstum (Koloniengröße) stark beschleunigt, und die Kolonien waren 4 - 5 mm groß. Sie erschienen auf den Petrischalen konvex, rund, gelblich und waren durch die Lipaseaktivität von einem Hof umrandet.

Ein noch stärkeres Wachstum, d. h. noch größere Kolonien, wurden durch Zugabe von Fruktose, Galaktose oder Saccharose zu Tween B erreicht. Hier erreichten die Kolonien einen Durchmesser von 6 - 9 mm und waren konvex, rundlich, weißlich und besaßen nur selten einen sehr schwachen Lipasehof. Durch den Laktosezusatz erreichten die Kolonien einen Durchmesser von nur 2 - 3 mm und wuchsen relativ langsam. Sie waren weißlich, flach, schleimig und hatten einen ausgeprägten Lipasehof, der bis in den Agar hineinreichte.

Schlussfolgerung: Der zusätzliche Zucker im Medium führte oft auch zu einer Veränderung der Farbe und Form der Kolonien von Xcp im Vergleich zum ursprünglich TweenMedium. Eine gute Wachstumsförderung und eine gute Differenzierbarkeit von den Kontaminanten wurde durch die Zugabe von 1\% Cellobiose erreicht.

\subsubsection{Einfluss der Borsäurekonzentration mit und ohne Cellobiose}

Durch Veränderung der Borsäurekonzentration in dem Tween-Medium sollte festgestellt werden, ob Änderungen in Form, Farbe und Größe der Kolonien von $X c p$ sowie in der Wachstumsgeschwindigkeit stattfanden. Zum autoklavierten, auf $55{ }^{\circ} \mathrm{C}$ abgekühlten Tween-Nährmedium wurde nach Sterilfiltration Cellobiose in 1\%iger Endkonzentration sowie die Borsäurelösung in verschiedenen Endkonzentrationen hinzugegeben. Beide Verbindungen wurden in destilliertem Wasser gelöst. Von Suspensionen der Bakterienarten Xсp (Stamm 1955), P. syringae, P. fluorescens und E. herbicola wurden Verdünnungsrei- 
hen durchgeführt und auf dem Medium verteilt. Nach 4 Tagen Inkubation bei $30^{\circ} \mathrm{C}$ erfolgte die Zählung der Kolonien, nach 6 und 9 Tagen die Beschreibung der Kolonien. Aus den gezählten Kolonien wurde die Effizienz des jeweiligen Mediums berechnet, d. h. die relative Kolonienzahl im Vergleich zu den Standardmedien (KB und NGA) in Prozent (Tab. 5).

Tab. 5: Effizienz (in Prozent) des Tween-Cellobiose-Mediums bei verschiedenen Borsäurekonzentrationen, ausgedrückt in Prozent zu Standard-Medien (KB und NGA)

\begin{tabular}{|l|l|l|l|l|l|}
\hline Nährmedium & $\begin{array}{l}\mathrm{H}_{3} \mathrm{BO}_{3} \\
\mathrm{~g} / \mathrm{l}\end{array}$ & $\begin{array}{l}\text { Xcp } \\
1955\end{array}$ & $\begin{array}{l}\text { P. fluor. } \\
1714\end{array}$ & $\begin{array}{l}\text { P. syr. } \\
1004\end{array}$ & $\begin{array}{l}\text { E. herb. } \\
450\end{array}$ \\
\hline \hline Tween+Cellobiose & - & 88 & 32 & 0 & 0 \\
\hline Tween+Cellobiose & 0,1 & 85 & 0 & 0 & 0 \\
\hline Tween+Cellobiose & 0,15 & 77 & 0 & 0 & 0 \\
\hline Tween+Cellobiose & 0,2 & 95 & 0 & 0 & 0 \\
\hline Tween+Cellobiose & 0,3 & 105 & 0 & 0 & 0 \\
\hline $\begin{array}{l}\text { Cellobiose ohne } \\
\text { Tween }\end{array}$ & 0,3 & 116 & 0 & 0 & 0 \\
\hline
\end{tabular}

$$
\text { Effizienz (\%) }=\frac{\text { Anzahl der Kolonien von } X c p \text { auf dem Selektivmedium X } 100}{\text { Anzahl der Kolonien von } X c p \text { auf dem Standardmedium }}
$$

Sechs Tage alte $X c p$-Kulturen bildeten 2 mm große Kolonien, die rund, glänzend, gelblich und ohne Lipasehof waren. Die verschiedenen getesteten Borsäurekonzentrationen hatten keinen Einfluss auf die Koloniengröße.

Auf dem gleichen Medium ohne Borsäure wuchsen die Xcp-Kolonien allerdings schneller (ca. 4 mm Durchmesser) und bildeten nach 5 Tagen einen Lipasehof. Auf dem borsäurefreien Tween-Medium bildete auch $P$. fluorescens Kolonien, deren Wachstum aber bereits nach Zugabe von 0,1 g/l Borsäure zum Medium völlig ausblieb. Die anderen beiden bakteriellen Kontaminanten konnten auf diesen Varianten nicht wachsen. Auf Grund dieser Versuche wurde die Borsäurekonzentration in dem Tween-Medium zur Isolation von Xcp gegenüber der originalen Zusammensetzung von 0,3 g/l nicht verändert. 


\subsubsection{Wirkung verschiedener Antibiotika}

Das entwickelte semiselektive Medium hatte jedoch den Nachteil, dass die Xcp-Kolonien etwas langsam wuchsen. Deswegen wurde eine große Zahl alternativer Antibiotika in Form von Testplättchen getestet, um das Wachstum der kontaminierenden Bakterien im Vergleich mit den gesuchten Bakterien selektiv zu hemmen. 
Tab. 6: Wirkung diverser Antibiotika auf verschiedene Bakterienarten durch Bildung von Hemmhöfen auf dem Nähragar. 1) +: Bakterienhemmung, 2).n.u: nicht untersucht

\begin{tabular}{|c|c|c|c|c|}
\hline Antibiotikum & Xср 2503 & P. fluor.1714 & E. herb.450 & P. syr. 1004 \\
\hline Ampicillin $10 \mu \mathrm{g}$ & $++^{1)}$ & - & + & + \\
\hline Augmentan $30 \mu g$ & + & - & + & + \\
\hline Cephoral 10 g ( Cefixim) & - & - & + & - \\
\hline Ciprofloxacin $5 \mu \mathrm{g}$ & + & + & + & + \\
\hline Cefpirom $30 \mu \mathrm{g}$ & - & - & + & - \\
\hline Cefotaxim $30 \mu \mathrm{g}$ & + & + & + & + \\
\hline Cefuroxim $30 \mu g$ & + & - & + & - \\
\hline Clindamycin $2 \mu \mathrm{g}$ & - & - & n. u. ${ }^{2)}$ & n. u. \\
\hline Clindamycin $10 \mu g$ & - & - & - & - \\
\hline Erythromycin $10 \mu \mathrm{g}$ & + & - & + & + \\
\hline Erythromycin $15 \mu \mathrm{g}$ & + & - & + & + \\
\hline Fusidinsäure $10 \mu \mathrm{g}$ & + & - & - & - \\
\hline Imipinem $10 \mu \mathrm{g}$ & + & + & + & + \\
\hline Lincomycin $15 \mu \mathrm{g}$ & - & - & - & - \\
\hline Meropenem $10 \mu \mathrm{g}$ & - & - & - & - \\
\hline Metronidazole $5 \mu \mathrm{g}$ & - & - & - & - \\
\hline Mezlocillin $30 \mu g$ & + & + & + & + \\
\hline Neomycin $30 \mu g$ & + & + & + & + \\
\hline Nalidixinsäure $30 \mu \mathrm{g}$ & + & - & + & + \\
\hline Tobramycin $10 \mu \mathrm{g}$ & + & + & + & + \\
\hline Tobramycin $30 \mu g$ & + & + & + & + \\
\hline Oxacillin $1 \mu \mathrm{g}$ & - & - & - & - \\
\hline Oxacillin $5 \mu \mathrm{g}$ & - & - & - & - \\
\hline Penicillin 5 Units & - & - & - & - \\
\hline Penicillin 10 I.E. & - & - & + & - \\
\hline P30T10 & + & + & + & + \\
\hline Polymyxin 300 I.E. & + & - & + & + \\
\hline Piperacillin $30 \mu g$ & + & + & + & + \\
\hline Rifampicin $2 \mu \mathrm{g}$ & - & + & + & + \\
\hline $\begin{array}{l}\text { Sulfamethoxazol }(23,75 \mu \mathrm{g}) \\
+ \text { Trimethoprim }(1,25 \mu \mathrm{g})\end{array}$ & + & + & + & + \\
\hline Tetracyclin $30 \mu \mathrm{g}$ & + & + & + & + \\
\hline Vancomycin $30 \mu g$ & + & - & - & - \\
\hline
\end{tabular}


Der geprüfte $X c p$ Stamm 2503 verhielt sich gegenüber den Antibiotika unterschiedlich (Tab. 6). Von fast allen eingesetzten Antibiotika wurde Xcp stark gehemmt. Nur Rifampicin $(2 \mu \mathrm{g})$ zeigte wie erwartet keine Hemmung, weil dieser Stamm gegen 100 ppm Rifampicin resistent ist. Die mitgetesteten Stämme von Pseudomonas fluorescens, Erwinia herbicola und Pseudomonas syringe pv. syringae reagierten dagegen unempfindlicher gegenüber den meisten Antibiotika. Die $X c p$ nicht hemmenden Verbindungen verursachten auch keinen Hemmeffekt auf die mitgeprüften Stämme von $P$. fluorescens, E. herbicola und $P$. syringae. Damit erwiesen sich diese Antibiotika als ungeeignet zur Verbesserung des Mediums.

In einem weiteren Versuch wurden die im Tween+Cellobiose-Medium bereits enthaltenen Antibiotika und zwei andere Antibiotika (Cefazolin und Phosphomycin) separat in verschiedenen Konzentrationen überprüft. Dazu wurden $100 \mathrm{ml}$ Portionen vom TweenCellobiose-Medium angesetzt und nach dem Autoklavieren bei $55{ }^{\circ} \mathrm{C}$ die verschiedenen Antibiotikakonzentrationen hinzugefügt (Tab. 7). Um die typischen Merkmale der Kolonien genau zu erfassen, wurde in diesem Versuch auf Verdünnungsausstriche verzichtet. Statt dessen wurden die geeigneten Verdünnungsstufen einer Verdünnungsreihe ausgewählt und ein aliquoter Teil davon in die Petrischalen verteilt. Zur Kontrolle wurde der gleiche Versuch mit King-B und NGA-Medium sowie mit dem gleichen TweenCellobiose-Medium ohne Antibiotika durchgeführt. 
Tab. 7: Einfluss unterschiedlicher Antibiotikakonzentrationen im Tween-CellobioseMedium auf das Wachstum von Bakterien

\begin{tabular}{|l|c|c|c|c|c|}
\hline Antibiotikum & $\begin{array}{l}\text { Konzentration } \\
(\mathrm{mg} / \mathrm{l})\end{array}$ & Xcp 2503 & E. herb.450 & P. syr. 1004 & P. fluor.1714 \\
\hline Tobramycin & 1 & + & $\mathrm{ng}$ & $\mathrm{ng}$ & $(+)$ \\
\hline & 1,2 & + & $\mathrm{ng}$ & $\mathrm{ng}$ & $(+)$ \\
\hline & 1,4 & + & $\mathrm{ng}$ & $\mathrm{ng}$ & $\mathrm{ng}$ \\
\hline & 1,6 & $(+)$ & $\mathrm{ng}$ & $\mathrm{ng}$ & $\mathrm{ng}$ \\
\hline & 3,0 & $\mathrm{ng}$ & $\mathrm{ng}$ & $\mathrm{ng}$ & $\mathrm{ng}$ \\
\hline 5-Fluorouracil & 3 & + & $\mathrm{ng}$ & $\mathrm{ng}$ & $(+)$ \\
\hline & 6 & + & $\mathrm{ng}$ & $\mathrm{ng}$ & $(+)$ \\
\hline & 12 & + & $\mathrm{ng}$ & $\mathrm{ng}$ & $(+)$ \\
\hline & 24 & $(+)$ & $\mathrm{ng}$ & $\mathrm{ng}$ & $\mathrm{ng}$ \\
\hline Phosphomycin & 0,4 & + & $(+)$ & $(+)$ & $(+)$ \\
\hline & 0,8 & + & $(+)$ & $(+)$ & $(+)$ \\
\hline & 1,2 & + & $(+)$ & $(+)$ & $(+)$ \\
\hline & 2,4 & $\mathrm{n} . \mathrm{g}$ & $(+)$ & $(+)$ & $(+)$ \\
\hline Cefazolin & 5 & + & + & + & + \\
\hline & 10 & + & + & + & + \\
\hline & 15 & + & + & + & + \\
\hline & 30 & + & + & + & + \\
\hline $\begin{array}{l}\text { Ohne Antibio- } \\
\text { tika }\end{array}$ & & + & + & $(+)$ & + \\
\hline
\end{tabular}

+ : gewachsen

$(+)$ : schwach gewachsen, Kolonien blieben klein ng : nicht gewachsen

In diesem Versuch (Tab. 7) verhielt sich der Xcp-Stamm 2503 gegenüber den Antibiotika unterschiedlich. Diese Unterschiede zeigten sich deutlich bei Tobramycin und 5Fluorouracil. Während $X c p$ durch Tobramycin (1,6 und 3,0 mg/l) gehemmt wurde, zeigte sich bei 5-Fluorouracil erst bei $24 \mathrm{mg} / \mathrm{l}$ eine schwache Hemmung. Tobramycin konnte deswegen von $0,4 \mathrm{mg} / \mathrm{l}$ auf 1,4 mg/l erhöht werden, um $P$. fluorescens zu unterdrücken, während 5-Fluorouracil von $12 \mathrm{mg} / \mathrm{l}$ auf $3 \mathrm{mg} / \mathrm{l}$ reduziert wurde, weil dieses Antibiotikum eine gewisse karzinogene Wirkung hat. Cefazolin zeigte bei Xcp keinen Hemmeffekt, hatte aber bei höheren Konzentrationen einen Einfluss auf die Koloniegröße, während die Kontaminanten nicht beeinflusst wurden. Durch Phosphomycin wurde $X c p$ bei 2,4 mg/l gehemmt.

E. herbicola und P. syringae wurden durch alle eingesetzten Konzentrationen von Tobramycin und 5-Fluorouracil total gehemmt, während $P$. fluorescens empfindlich gegenüber 
5-Fluorouracil reagierte, und erst durch $1,4 \mathrm{mg} / \mathrm{l}$ Tobramycin total unterdrückt wurde. Phosphomycin hemmte die Begleitbakterien schwach, und erst bei 2,4 mg/l wurde Xcp gehemmt. Cefazolin hemmte in den eingesetzten Konzentrationen die Begleitbakterien überhaupt nicht.

Wegen dieser Versuchsergebnisse wurde für das neue Tween+Cellobiose-Medium eine Kombination von 3 mg/l 5-Fluorouracil und 1,4 mg/l Tobramycin gewählt. Das Medium wird im Folgenden als TC-Medium bezeichnet.

\subsection{Zusammensetzung des neuen semiselektiven TC-Mediums für $X c p$}

Zusammensetzung des veränderten semiselektiven Nährmediums für Xanthomonas campestris pv. pelargonii (Angaben für 1 Liter Medium)

$\begin{array}{lc}\text { Pepton } & 10,0 \mathrm{~g} \\ \mathrm{KBr} & 10,0 \mathrm{~g} \\ \mathrm{CaCl}_{2} & 0,25 \mathrm{~g} \\ \mathrm{H}_{3} \mathrm{BO}_{3} & 0,30 \mathrm{~g} \\ \text { Bacto-Agar } & 16.0 \mathrm{~g} \\ \text { pH } & 7,4 \\ \text { Bidest. } \mathrm{H}_{2} \mathrm{O} & 1000 \mathrm{ml}\end{array}$

Nach dem Autoklavieren und Abkühlen auf $55^{\circ} \mathrm{C}$ aseptisch hinzufügen:

Tween 80

$10,0 \mathrm{ml}$

Cellobiose

$10,0 \mathrm{~g}$

Cycloheximid

$50,0 \mathrm{mg}$

Cephalexin

$65,0 \mathrm{mg}$

5-Fluorouracil

$3,0 \mathrm{mg}$

Tobramycin

$1,4 \mathrm{mg}$ 


\subsection{Wiederfindungsrate von $X c p$ im Pflanzenhomogenat}

In diesem Versuch wurde die Nachweisempfindlichkeit von Xcp durch Isolationen auf dem neuen TC-Medium getestet. Als Kriterium wurde die Wiederfindungsrate (WR) herangezogen. Diese Größe gibt an, welcher Prozentsatz einer bestimmten Bakterienmenge, die mit einer Pflanzenprobe vermischt wurde, mit Hilfe des TC-Mediums gefunden werden konnte. Die Vorgehensweise war wie folgt:

Aus den Pelargoniensorten „Rosario“ wurden Stengelstücke entnommen, in 70\% Ethanol getaucht und kurz abgeflammt. Von einer frischen Kultur des Xcp-Stammes 2503 wurde eine Suspension mit etwa $10^{8} \mathrm{cfu} / \mathrm{ml}$ angesetzt. Von der Suspension wurden $100 \mu \mathrm{l}$ in die Pflanze mit einer Injektionskanüle inokuliert. Unmittelbar danach wurde diese Stengelpartie (0,5 g) in 4,5 ml $\mathrm{MgSO}_{4}$-Lösung homogenisiert und davon eine Verdünnungsreihe hergestellt. Alle Verdünnungen wurden auf TC-Medium und NGA-Medium ausplattiert. Nach 5 Tagen Inkubation wurden die aufgetretenen Kolonien ausgezählt. Von jedem Ansatz wurden mindestens 2 Petrischalen beimpft.

Die Verwendung von exakt definierten Bakterienmengen und das Verarbeiten des Inokulums mit Pflanzengewebe des Wirtes erlaubten genaue Rückschlüsse über die Qualität des Mediums. Es sollte festgestellt werden, ob es zwischen Bakterien und Pflanzengewebe zu Interaktionen kommt, die zu einer Beeinträchtigung der Nachweisempfindlichkeit führen. Auf dem TC-Medium wuchsen insgesamt mehr Bakterien als auf dem NGAStandardmedium, und fast alle gehörten zu Xcp. Außerdem erlaubte das TC-Medium eine sehr gute Differenzierung der verschiedenen Bakterienarten.

Das TC-Medium zeichnete sich somit durch eine hohe Wiederfindungsrate der Bakterien in Gegenwart von Pflanzengewebe aus. Die den Pflanzen zugefügten Bakterien konnten in der Größenordnung von 100\% wiedergefunden werden (Tab. 8).

Tab. 8: Wiederfindungsrate von $X$. pelargonii im Pflanzenhomogenat

\begin{tabular}{l|cc}
\hline & NGA- Medium & TC-Medium \\
\hline \hline Zugegeben & $1 \times 10^{7}$ & $1 \times 10^{7}$ \\
Gefunden & $9 \times 10^{6}$ & $1 \times 10^{7}$ \\
Wiederfindungsrate & $90 \%$ & $100 \%$ \\
\hline
\end{tabular}

Wiederfindungsrate $\left(\right.$ WR \%) $=\frac{\text { Gefundene } X \text {. pelargonii Bakterien X } 100}{\text { Zugegebene } X \text {. pelargonii Bakterien }}$ 


\section{6 Überprüfung der Selektivität des neuen TC-Mediums}

Die Versuche wurden mit einem Gemisch der Bakterienarten Xcp, P. fluorescens, $P$. syringae und E. herbicola durchgeführt. Von jedem Bakterienstamm wurde jeweils eine Suspension mit ca. $10^{8} \mathrm{cfu} / \mathrm{ml}$ hergestellt. Der Stamm Xcp 2503 wurde zunächst auf NGA vorkultiviert, um eine typische Kolonie zu erhalten, welche dann auf Rhodes-Nähragar zur Herstellung der Suspension ausgestrichen wurde. Auf diesem Medium wächst Xcp nicht so voluminös, das gebildete Material enthält wenig Schleim und lässt sich leicht suspendieren. Die übrigen Bakterien wurden auf King-B vorkultiviert. Aus den einzelnen Suspensionen wurde eine Mischsuspension sämtlicher Bakterienstämme hergestellt und für die Inokulationen der Pelargonien (Sorte "Rosario“) benutzt. Die Inokulation der jungen Pflanzen erfolgte durch Injektion des Inokulums in den zarten Stengel mit Hilfe einer feinen Injektionskanüle.

Die ersten sichtbaren Symptome traten bereits nach 6 Tagen am Stengel auf. Nun wurden Stengelteile mit Symptomen entnommen und in 70\% Ethanol getaucht, um oberflächlich anhaftende Bakterien und Pilze abzutöten. Von jeder Probe wurde ein Stückchen von 0,5 g im sterilen Mörser homogenisiert. Die verdünnten Homogenate wurden auf TC-Medium sowie auf den Standardmedien NGA und King-B verteilt und die Petrischalen bei $28{ }^{\circ} \mathrm{C}$ inkubiert. Zusätzlich wurden mit der bakteriellen Mischsuspension Petrischalen beimpft, um die Selektivität zu bestimmen. Die Selektivität ließ sich als das Verhältnis der XcpKolonien zur Gesamtkolonienzahl berechnen.

Tab. 9: Bestimmung der Selektivität des TC-Mediums für Xcp nach Verwendung künstlich infizierter Pelargonien mit bakteriellen Mischkulturen (cfu / ml Mischinokulum)

\begin{tabular}{l|l|l|l}
\hline Medium & Xcp Kolonien & Selektivität (\%) & Differenzierbarkeit \\
\hline \hline TC & $9 \times 10^{7}$ & 100 & sehr gut \\
\hline
\end{tabular}

$$
\text { Selektivität (\%) }=\frac{\text { Summe der Kolonien des Zielbakteriums auf Medium A X } 100}{\text { Summe aller Bakterienkolonien auf Medium A. }}
$$

Von den 4 geprüften Bakterienarten konnte auf dem TC-Medium nur der Xcp-Stamm wachsen, während $P$. fluorescens, $P$. syringae und E. herbicola kein Wachstum zeigten. 
Das Medium besaß also eine 100\%ige Selektivität (Tab. 9). Andererseits wurde auf NGAMedium das Wachstum von Xcp durch das Vorkommen von Saprophyten sehr stark gehemmt (Abb. 1).

Neben der sehr hohen Selektivität erlaubte das Nährmedium eine sehr gute Differenzierung der Kolonien. Die Xcp-Kolonien auf dem Medium waren leicht konvex, rundlich, gelblich bis gelb, mit einem Durchmesser von 3 - 7 mm. Das Wachstum von Xcp auf dem TCMedium war schnell. Nach 4 Tagen bei $28^{\circ} \mathrm{C}$ waren die Kolonien $3 \mathrm{~mm}$ groß, und um die Kolonien herum bildete sich ein leichter Lipasehof (Abb. 2).

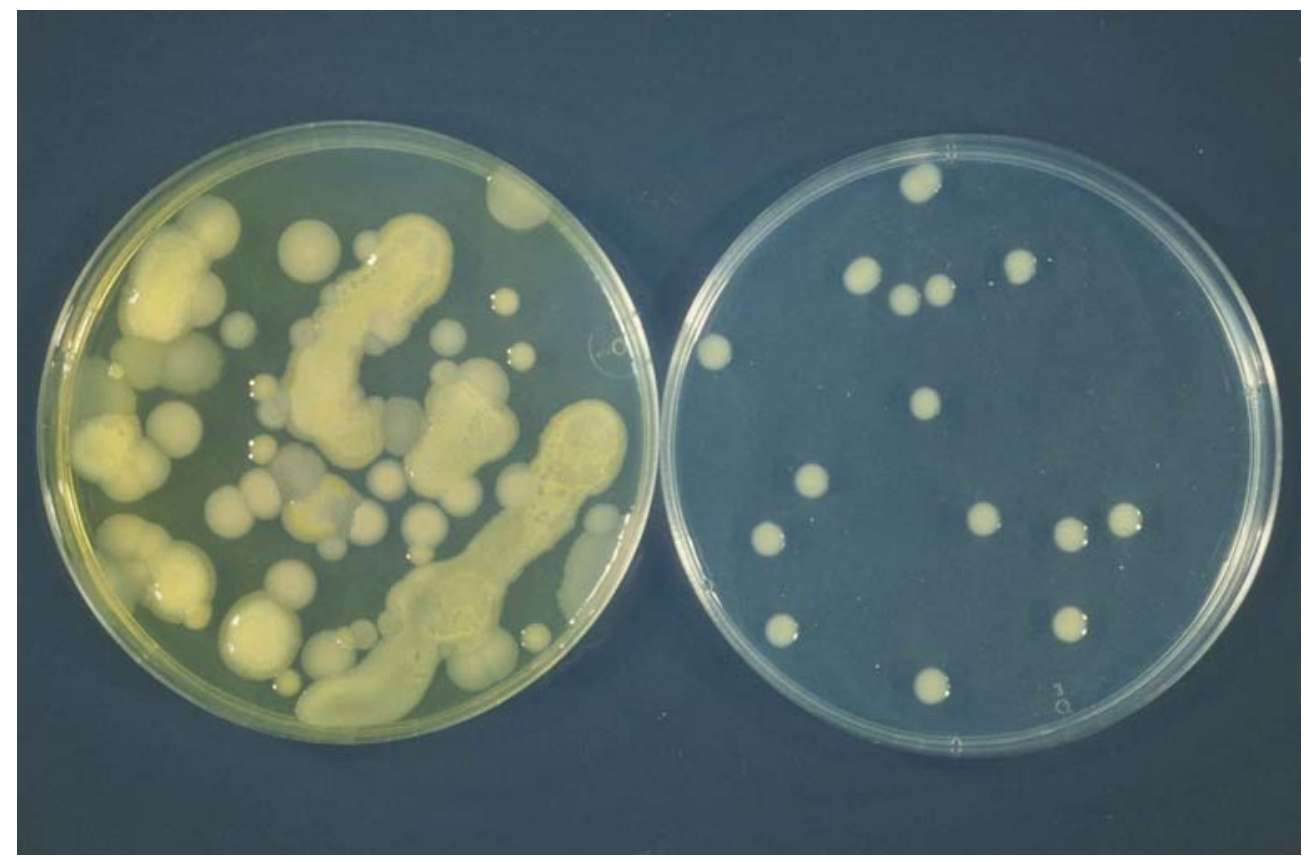

Abb. 1: Wachstum einer Bakterienmischpopulation (aus einem Homogenat von Pelargo nienstengeln mit Xcp, E. herbicola, P. fluorescens und P. syringae) auf dem NGA-Medium (links) und dem neuen TC-Medium (rechts). 


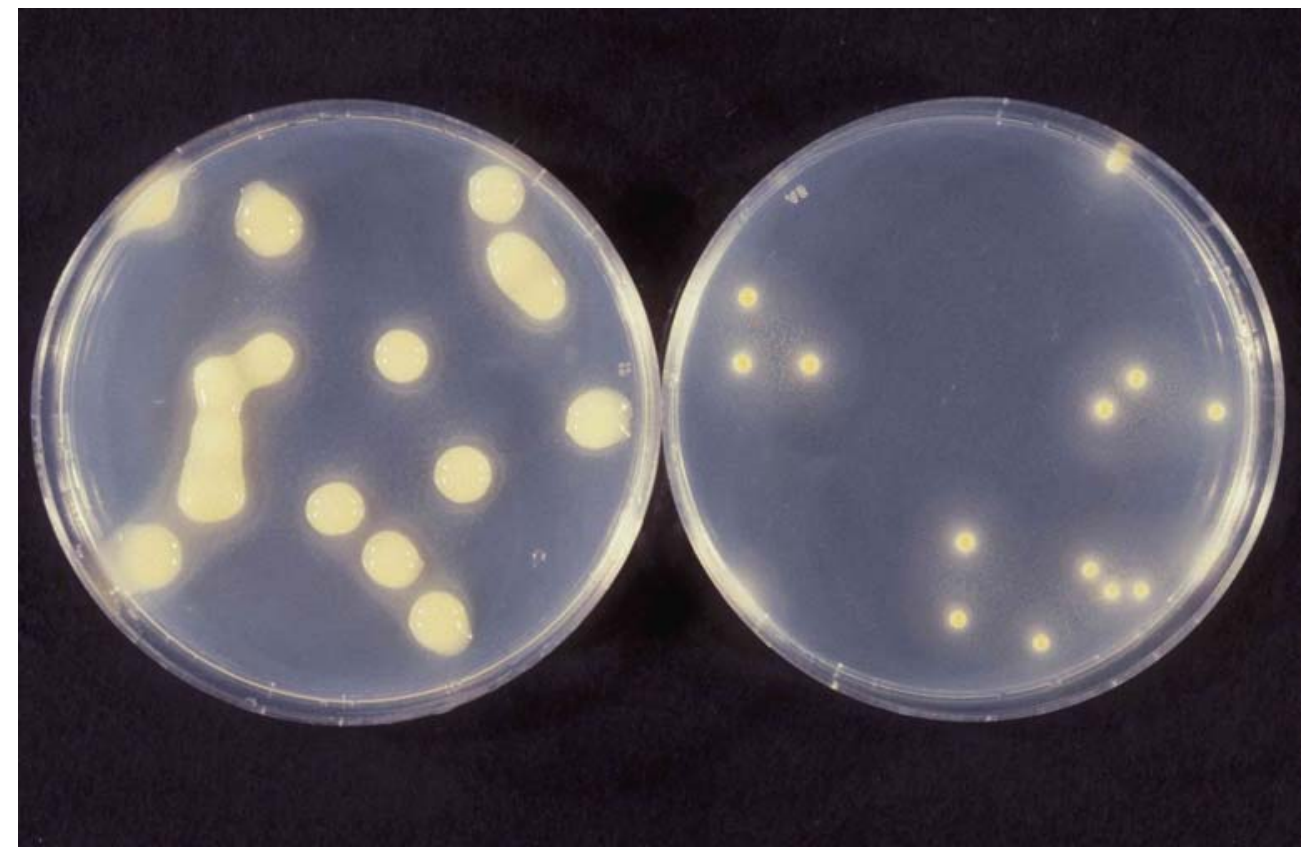

Abb. 2: Vergleich der $X c p$-Kolonien auf dem modifizierten Tween-Cellobiose-Medium (links) und dem originalen Tween-Medium (rechts)

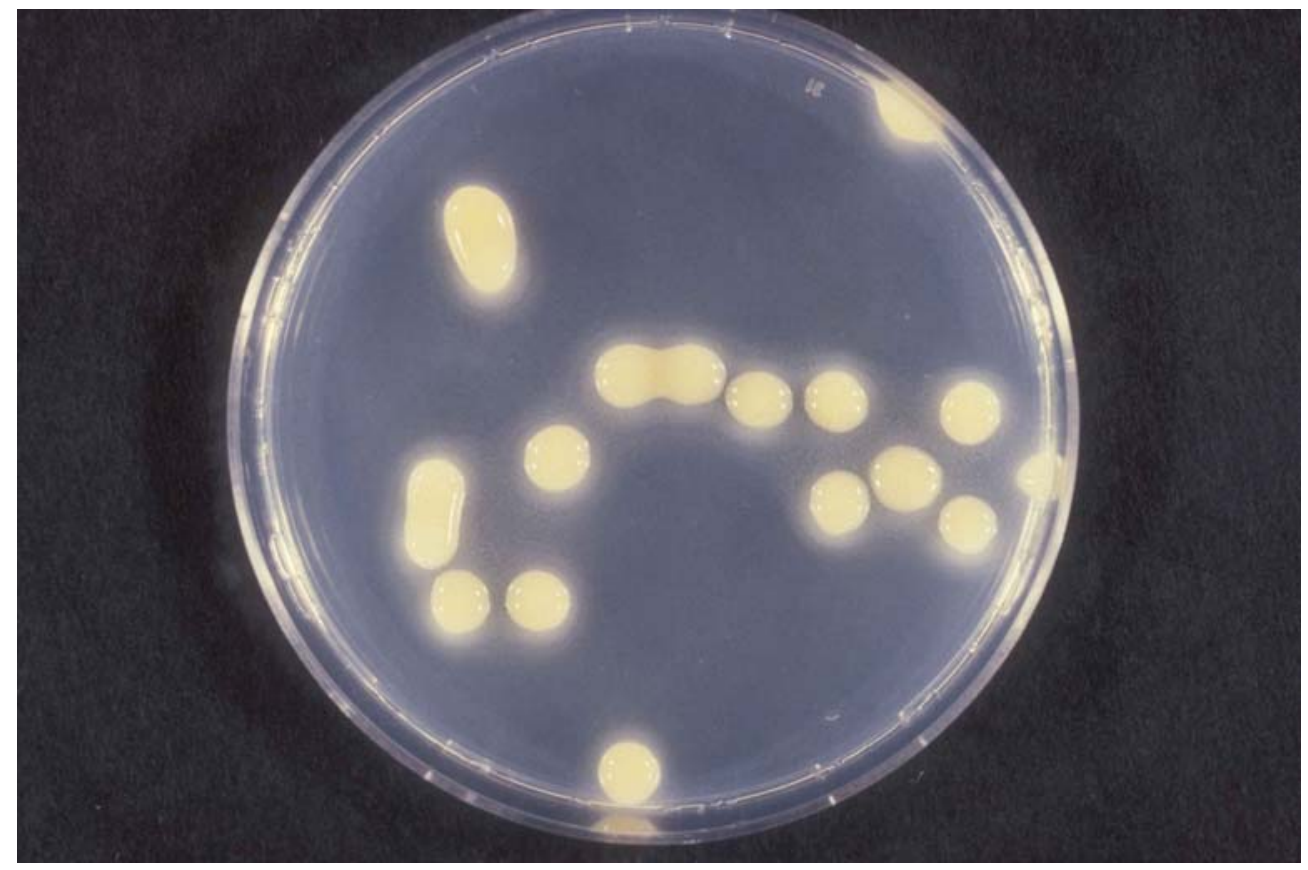

Abb. 3: Wachstum von Xcp-Kolonien auf dem TC-Medium aus einem Homogenat von Pelargonienstengeln mit einer Suspension von Xcp, E. herbicola, $P$. fluorescens und $P$. syringae. Nur Xcp wuchs auf diesem Medium. 


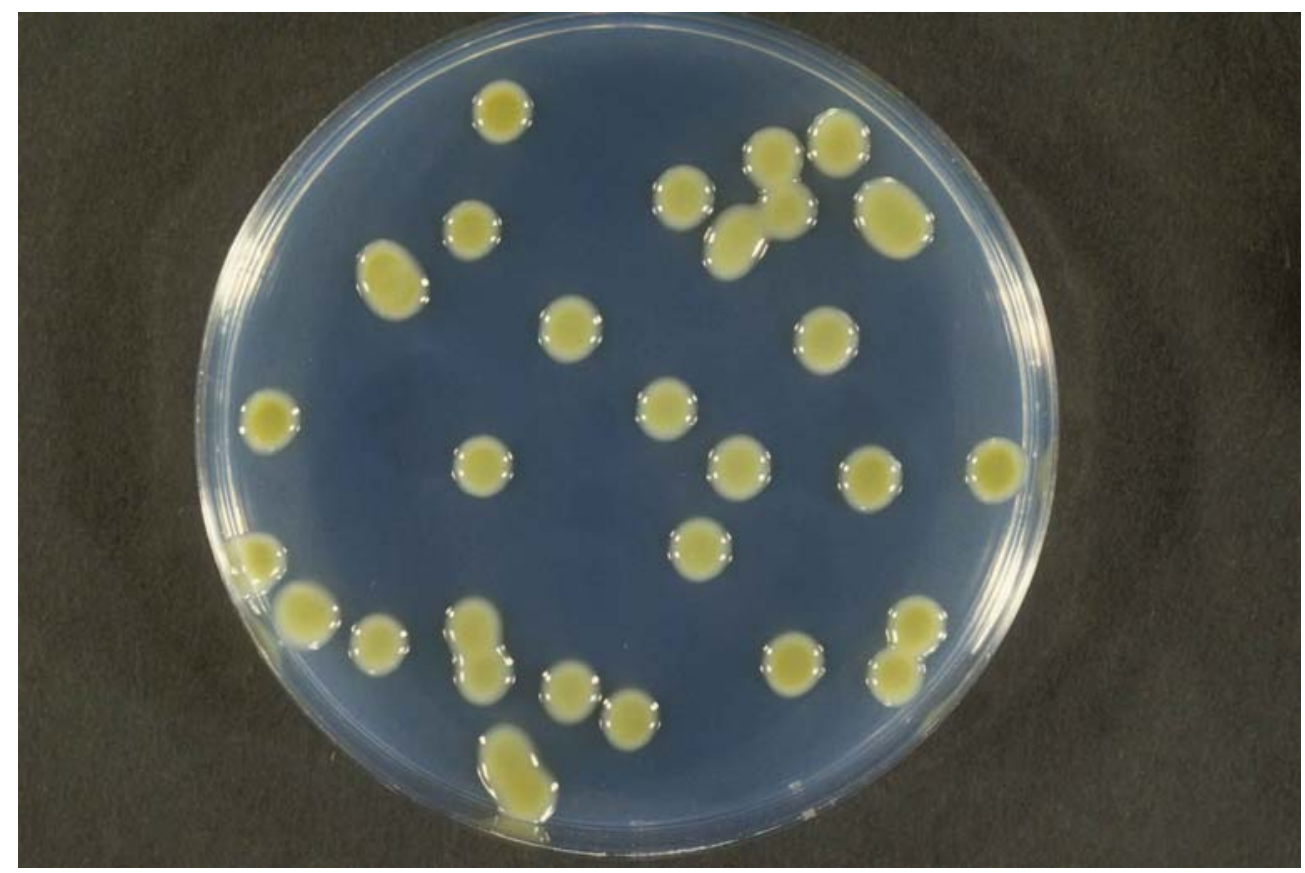

Abb. 4: Wachstum von Xcp-Kolonien auf dem MD5A-Medium in Bakterienreinkulturen

\subsection{Wachstum verschiedener $X c p$-Stämme auf dem neuen TC-Medium}

Sechzehn verschiedene $X c p$-Stämme aus der Göttinger Sammlung Phytopathogener Bakterien (GSPB) wurden auf dem TC-Medium und dem NGA-Medium getestet. Durch Verdünnungsreihen und Ausplattierungen wurden die cfu/ml ermittelt. Nach 5 - 6 Tagen Inkubation bei $30{ }^{\circ} \mathrm{C}$ wurden die Kolonien genau beschrieben und ihre Anzahl bestimmt.

Die Kolonien fast aller Stämme waren auf dem Medium sehr ähnlich, d. h. leicht konvexe, gelbliche, rundliche bis runde Kolonien mit einem Durchmesser von 3 - 6 mm. Nur die Stämme 191 und 2514 wuchsen sehr langsam und konnten erst nach 10 Tagen eindeutig erkannt werden.

Alle getesteten Stämme konnten auf dem TC-Medium gut wachsen, und die Anzahl ihrer Kolonien variierte nur geringfügig gegenüber dem NGA-Medium (Tab. 10). 
Tab. 10: Wachstumsvergleich verschiedener $X c p$-Stämme auf dem neuen TC-Medium und dem NGA-Medium zum Vergleich (cfu/ml)

Stamm

TC-Medium

NGA-Medium

\begin{tabular}{lcc}
\hline Хср 191 & $9 \times 10^{6}$ & $8 \times 10^{6}$ \\
Хср 197 & $6,2 \times 10^{7}$ & $7 \times 10^{7}$ \\
Хср 203 & $8,8 \times 10^{7}$ & $1 \times 10^{8}$ \\
$X с p 1955$ & $4,3 \times 10^{7}$ & $4,4 \times 10^{7}$ \\
$X с p 1957$ & $4 \times 10^{7}$ & $4,3 \times 10^{7}$ \\
$X с p 2104$ & $3,8 \times 10^{7}$ & $4 \times 10^{7}$ \\
$X с p 2105$ & $1,6 \times 10^{7}$ & $2,5 \times 10^{7}$ \\
$X с p 2503$ & $4,9 \times 10^{7}$ & $3,2 \times 10^{7}$ \\
$X с p 2513$ & $3,5 \times 10^{7}$ & $3 \times 10^{7}$ \\
$X с p 2514$ & $1,8 \times 10^{7}$ & $3,6 \times 10^{7}$ \\
$X с p 2630$ & $1,1 \times 10^{8}$ & $1 \times 10^{8}$ \\
$X с p 2632$ & $6,3 \times 10^{7}$ & $4,9 \times 10^{7}$ \\
$X с p 2634$ & $2,1 \times 10^{7}$ & $2,6 \times 10^{7}$ \\
$X с p 2638$ & $4,7 \times 10^{7}$ & $5,4 \times 10^{7}$ \\
$X с p 2640$ & $6,9 \times 10^{7}$ & $5 \times 10^{7}$ \\
$X с p 2642$ & $5,2 \times 10^{7}$ & $7,2 \times 10^{7}$ \\
\hline
\end{tabular}




\section{DISKUSSION}

In der Praxis werden seit vielen Jahren verschiedene serologische Techniken, vor allem der ELISA- und Immunfluoreszenz-Test (IF-Test) (Kapitel III), und in letzter Zeit die Polymerase-Kettenreaktion (PCR) zum Nachweis phytopathogener Bakterien eingesetzt. Die Nachweisempfindlichkeit dieser Verfahren reicht jedoch nicht aus, um geringe Bakterienkonzentrationen (oft unter $10^{4} \mathrm{cfu} / \mathrm{ml}$ ) zu erfassen. Von den erwähnten Methoden besitzt die PCR-Technik eine sehr gute Reproduzierbarkeit bei hoher Empfindlichkeit (siehe Kapitel IV).

Die klassische mikrobiologische Methode, d. h. Herstellung von Verdünnungsreihen und Ausplattieren auf Nährmedien, besitzt normalerweise die höchste Nachweisempfindlichkeit, ist aber gleichzeitig mit Nachteilen verbunden. Die meisten Nährmedien besitzen entweder keine oder nur eine geringe Selektivität und erlauben nicht nur das Wachstum des Zielbakteriums sondern auch zahlreicher anderer Bakterien und besonders vieler Saprophyten. Die Saprophyten sind in der Regel schnellwüchsiger als die phytopathogenen Bakterien und überwuchern sie, oder sie hemmen durch Ausscheidung von Stoffwechselprodukten den Zielorganismus und erschweren dadurch seinen Nachweis beträchtlich.

Deshalb wird seit Jahren versucht, durch die Entwicklung selektiv wirkender Medien für bestimmte Bakterien günstige Wachstumsbedingungen zu schaffen (ROY and SASSER, 1990). Viele dieser Medien wurden primär zur Isolierung anderer Xanthomonas Pathovarietäten entwickelt, aber einige davon wurden auch für die Isolation von $X c p$ erprobt.

Im Rahmen dieser Arbeit wurden zahlreiche bereits bekannte semiselektive Nährmedien auf ihre Eignung zur Isolierung von $X c p$ überprüft. Die erfolgversprechendsten wurden dann modifiziert und ergänzt, um eine möglichst hohe Selektivität für die Isolierung von Xсp zu erzielen.

Zunächst wurden die Medien KM-1 und XTS nach Zugabe von 10 mg/ml Vancomycin überprüft. Dadurch wurde das Wachstum von Erwinia herbicola auf XTS gehemmt, und auf KM-1 wuchs Pseudomonas syringae nur schwach. Jedoch wuchsen die Pseudomonaden immer noch schneller als Xcp. Auf den Nährmedien MXP und BSCAA konnte Xcp nur sehr schwach wachsen. Deshalb schieden diese Medien für weitere Versuche aus.

Ein relativ gutes Wachstum von Xcp wurde auf dem Nährmedium CS beobachtet, während auf ET die gebildeten Kolonien relativ klein blieben. Allerdings konnten auf beiden Me- 
dien auch die mitgetesteten Stämme von E. herbicola, P. syringae und P. fluorescens wachsen. Die Unterscheidung der $X$. pelargonii-Kolonien von den anderen Bakterien war nur auf dem CS-Medium leicht. D. h. auf dem CS-Medium waren die Xcp-Kolonien cremefarben mit einem roten Zentrum, wenn die Petrischalen einen relativ schwachen Kolonienbesatz aufwiesen. $P$. fluorescens Kolonien waren nicht immer deutlich von Xcp zu unterscheiden, und $P$. syringae-Kolonien wuchsen auf dem CS-Medium sehr zahlreich, verglichen zum Standard-Medium. Die Medien MSP und WBC erwiesen sich für eine schnelle und sichere Isolation von $X$. pelargonii als ungeeignet.

Alle oben erwähnten semiselektiven Nährmedien erwiesen sich jedoch als unbefriedigend für die gezielte Isolierung von $X$. pelargonii. Obwohl mehrere Medien eine gute Differenzierbarkeit der Kolonien ermöglichten, war die Selektivität immer noch ungenügend.

Von allen getesteten Nährmedien bot das Tween-Medium die beste Voraussetzung für die Entwicklung eines geeigneten Nährmediums zur Isolierung von $X$. pelargonii. Dieses Medium wurde als Tween-Medium ursprünglich für die Isolation von Xanthomonas campestris pv. vesicatoria entwickelt (McGUIRE et al., 1986). In diesem Medium ist Tween als C-Quelle und als Substrat für lipolytische Enzyme der Bakterien vorhanden. Xanthomonas campestris pv. pelargonii wuchs auf diesem Medium nur sehr langsam und bildete nach 10 Tagen Wachstum runde, gelbe, glänzende, schwach erhabene Kolonien mit einem Durchmesser von maximal $2 \mathrm{~mm}$. Auf Grund der Lipaseaktivität zeigten sich um die Kolonien herum milchige Höfe, die durch die Ausfällung der nach Aufspaltung von Tween 80 freigewordenen Fettsäuren mit den Kalziumionen entstehen.

Durch die Zugabe verschiedener organischer Verbindungen als zusätzliche C-Quelle zum Tween-Medium wurde versucht, seine Eigenschaften für unser Vorhaben zu optimieren. Es wurde dabei neben der Kolonienzahl auch die Wachstumsgeschwindigkeit und Differenzierbarkeit im Vergleich zum original Tween-Medium registriert.

Die Kombination des Tween-Mediums mit einer der Verbindungen Fruktose, Galaktose, Saccharose und Glukose bewirkte eine deutliche Wachstumsverbesserung von X. pelargonii. Die Kolonienvergrößerung durch die Zugabe der Zucker beruhte offensichtlich auf stärkerer Schleimbildung, da die Bakterienzahl/ml nicht erhöht wurde. Auch die Zugabe von Laktose, Xylose, Melibiose, Trehalose sowie Trehalose mit Laktose kombiniert führte zu einer, wenn auch schwächeren, Wachstumsstimulation. Diese Zucker führten oft auch zu einer Veränderung der Farbe und Form der Kolonien von Xcp im Vergleich zum ur- 
sprünglich Tween-Medium. Eine gute Wachstumsförderung und eine gute Differenzierbarkeit wurde durch die Zugabe von 1\% Cellobiose erreicht. Da diese Kohlenhydratquelle nicht von allen Saprophyten ebenso gut wie von Xcp verwertet werden kann, wurde Cellobiose dem Tween-Medium hinzugefügt.

In einem umfangreichen Versuch wurde die Auswirkung verschiedener Borsäurekonzentrationen auf die Eigenschaften des Tween-Mediums überprüft. Bei einem völligen Verzicht wuchsen die $X c p$-Kolonien schneller und besaßen nach 5 Tagen einen Durchmesser von 4 mm. Das Fehlen der Borsäure in dem Medium ermöglichte aber das Wachstum von P. fluorescens. Eine Borsäurekonzentration bis 0,3 g/l hatte keinen hemmenden Einfluss auf X. pelargonii. Eine darüber hinaus gehende Erhöhung des Borsäuregehaltes wirkte sich nicht nur auf Kolonienzahl von $X c p$ negativ aus, sondern machte auch die Identifizierung schwieriger. Dabei bildeten die $X c p$-Isolate flache und helle Kolonien, und die Bildung des Lipasehofes blieb entweder aus oder setzte später ein. Aus diesem Versuch ging hervor, dass eine Borsäurekonzentration von 0,3 g/l dem Tween-Medium eine ausgezeichnete Selektivität verleiht und $X$. pelargonii ein gutes Wachstum erlaubt.

Durch weitere Modifizierungen des Tween-Cellobiose-Mediums wurde versucht, das Wachstum der Xcp-Kolonien noch weiter zu verbessern; denn erst nach 7 Tagen Inkubation bei $30^{\circ} \mathrm{C}$ waren die Kolonien auf den Tween-Cellobiose-Medium gut zu identifizieren. Deswegen wurde nach Antibiotika gesucht, welche in Kombination mit dem TweenCellobiose-Medium ein selektives Wachstum von Xcp ermöglichten. Der Versuch wurde mit fertigen getränkten Testplättchen in verschiedenen Konzentrationen durchgeführt. Der Xcp-Stamm 2503 wurde nicht von allen geprüften Antibiotika gehemmt, wie z. B. Cephoral $(10 \mu \mathrm{g})$ oder Oxacillin (1 oder $5 \mu \mathrm{g})$ (Tab. 2).

Allerdings konnten mit diesen Antibiotika auch P. fluorescens, P. syringae und E. herbicola wachsen. Deshalb konnte keines der geprüften Antibiotika für das Medium herangezogen werden.

Des weiteren wurden die im Tween-Medium enthalten Antibiotika 5-Fluorouracil, Tobramycin und zwei weitere Antibiotika (Cefazolin und Phosphomycin) in verschiedenen Konzentrationen getestet, um die optimale Kombination zu ermitteln. Durch die höchste Cephalexinkonzentration (200 mg/l) wurden der Xcp-Stamm 203 und P. fluorescens gehemmt, während $P$. syringae bei allen Konzentrationen inhibiert wurde. Cephalexin ist gegen Gram-negative und Gram-positive Bakterien wirksam, aber weitgehend wirkungslos 
gegen Enterokokken (OTTEN, 1975). Das Antibiotikum 5-Fluorouracil wirkt in erster Linie gegen fluoreszierende Pseudomonaden. P. fluorescens und $P$. syringae wurden bereits mit $12 \mathrm{mg} / \mathrm{l}$ 5-Fluorouracil gehemmt, während die $X c p$-Isolate erst bei $24 \mathrm{mg} / \mathrm{l} \mathrm{5-}$ Fluorouracil Wachstumsbeeinträchtigungen aufwiesen. Tobramycin hatte bei 1,6 und 3,0 mg/l eine negative Wirkung auf die Xcp-Isolate. Das Antibiotikum Cefazolin hemmt in der Regel Gram-negative Bakterien (KARIYONE et al., 1970). Bei den Untersuchungen mit Cefazolin (10 mg/l) auf dem CCM-Medium wurde das Wachstum von Xanthomonas campestris pv. vignicola schwach gehemmt (KHATRI-CHHETRI, 1999), während Xcp bis zu 30 mg/l auf dem TC-Medium keine Hemmung zeigte. Das Antibiotikum Phosphomycin hat eine umfassende antibakterielle Wirkung (KAHAN et al., 1974; WOODRUFF et al., 1975). Durch Zugabe von Phosphomycin (2,5 mg/l) auf dem CTA-Medium (FESSEHAIE, 1997) wurden die von den Cassavapflanzen kommenden Kontaminanten unterdrückt, ohne das Wachstum von Xanthomonas campestris pv. manihotis zu beeinträchtigen. Bei Zugabe von Phosphomycin zum TC-Medium wuchs $Х с p$ bei allen geprüften Konzentrationen gut. Allerdings zeigten die Saprophyten noch ein schwaches Wachstum.

Auf Grund dieser Versuche wurde die Konzentration von 5-Fluorouracil von 12 mg/l auf 3 mg/l reduziert, während Tobramycin von 0,4 mg auf 1,4 mg/l erhöht wurde. Die Reduzierung der Konzentration von 5-Fluorouracil war auch deswegen vorteilhaft, weil dieses Antibiotikum eine gewisse karzinogene Wirkung hat. Auf dem so modifizierten TweenCellobiose-Medium wuchs das Zielbakterium $Х c p$ wesentlich schneller und bildete bereits nach 4 Tagen Kolonien von 3 mm Durchmesser; die Bildung des Lipasehofes setzte später ein. Das so modifizierte neue Medium wird im Folgenden als TC-Medium bezeichnet.

Wegen des Gehalts der karzinogenen Verbindung 5-Fluorouracil im TC-Medium wurden als Alternative verschiedene Variationen das MD5-Mediums geprüft. Auf dem unveränderten, für die Isolation von Xanthomonas campestris pv. carotae entwickelten Medium (KUAN, 1985) wuchs $X c p$ auffallend langsam. Nach 7 Tagen Wachstum bei $30{ }^{\circ} \mathrm{C}$ betrug der Koloniendurchmesser nur 1 bis 2 mm und nach 12 Tagen 4 - 8 mm. Auch E. herbicola, und deutlich schwächer $P$. syringae und $P$. fluorescens, wuchsen auf diesem Medium. Zugabe verschiedener Konzentrationen von Borsäure bewirkte keine Verbesserung. Weitere Versuche müssten zeigen, ob durch die Zugabe von 1\% Pepton nicht nur Xcp sondern auch verschiedene Kontaminanten im Wachstum stark gefördert werden. Wenn Gram- 
positive Bakterien als Kontaminanten keine große Rolle spielen, könnte das Antibiotikum Bacitracin ganz weggelassen werden, um ein besseres Wachstum von Xcp zu ermöglichen.

Schließlich wurde dem MD5-Medium das relativ neue Antibiotikum Aztreonam in den Konzentrationen 0,4 und 0,8 $\mathrm{mg} / \mathrm{ml}$ beigemischt. Aztreonam hemmt Gram-positive Bakterien und Anaerobier, zeigt aber auch eine gute Wirkung gegen Gram-negative, aerobe Bakterien (BENITZ und TATRO, 1988). Die Aztreonamzugabe beeinflusste das Wachstum von $X$. pelargonii nicht wesentlich, obwohl die Kolonienzahl etwas reduziert wurde. Andererseits wurde das Wachstum von E. herbicola mit beiden Konzentrationen völlig unterdrückt, und $P$. syringae wuchs dabei so schwach, dass die Kolonien nach 12 Tagen nur 0,5 mm groß waren. Auch P. fluorescens wurde etwas gehemmt und bildete typische sternförmige Kolonien. Die Unterdrückung von E. herbicola auf dem neuen MD5A-Medium ist sehr vorteilhaft, weil E. herbicola sehr häufig auf Pelargonien als Epiphyt vorkommt und wegen der gelben Kolonien mit Xcp verwechselt werden kann. Deswegen bietet sich dieses Medium als Alternativmöglichkeit zur Isolierung von $X$. pelargonii an, wenn das TCMedium wegen des Gehalts von 5-Fluorouracil nicht eingesetzt werden soll.

Um die Eignung des neu zusammengesetzten TC-Mediums für die Isolierung von $X c p$ aus Pelargonien zu überprüfen, wurde ein Vergleich mit dem Standard-Medium NGA durchgeführt. Dabei wurden Pflanzenproben mit Bakteriensuspensionen homogenisiert und auf den Nährmedien aliquote Teile der Homogenate ausgestrichen. Durch Auszählung der entstandenen Bakterienkolonien wurden die Selektivität und die Wiederfindungsrate der Nährmedien ermittelt.

Es zeigte sich, dass das TC-Medium eine hohe Selektivität besaß und eine gute Differenzierung von Xcp erlaubte. Besitzt ein Nährmedium eine hohe Selektivität, so ist die Nachweisempfindlichkeit dieses Mediums sehr hoch, und auch bei starker Kontamination der Pflanzenproben mit anderen Bakterien kann das gesuchte Bakterium ausfindig gemacht werden. Dies beruht auf der Fähigkeit des Nährmediums, die Begleitflora in der Pflanzenprobe stark zu hemmen, d. h. die Anzahl der auf diesem Medium gewachsenen Kolonien im Vergleich zum Standardmedium stark zu reduzieren.

Ein anderes wichtiges Merkmal für die Qualität eines selektiven Nährmediums ist seine Wiederfindungsrate (WR). Eine hohe WR bedeutet, dass das Nährmedium eine hohe Se- 
lektivität und gute Wachstumseigenschaften für das Zielbakterium besitzt. Das TCMedium zeichnet eine hohe WR auch bei niedriger Bakterienpopulation aus.

In einem praxisähnlichen, langwierigen Versuch wurde die WR des TC-Mediums getestet. Pelargonien wurden mit einem Mischinokulum bestehend aus $P$. fluorescens, $P$. syringae, E. herbicola und $X$. pelargonii inokuliert und nach 7 Tagen die Bakterien reisoliert. Bei der Rückisolation ermöglichte das TC-Medium eine Wiederfindungsrate von 100\%. Die Identifikation der Bakterien war auf Grund von Farbe, Form der Kolonien sowie der Lipasehofbildung um die Kolonien und wegen der Wachstumsgeschwindigkeit unproblematisch.

Alle getesteten Xcp-Stämme konnten auf dem TC-Medium gut wachsen, mit Ausnahme der Stämme 191 und 2514. Eine Überprüfung der Pathogenität der Stämme 191 und 2514 ergab, dass typische Krankheitssymptome erst nach längerer Zeit auftraten. Es wird vermutet, dass diese Stämme wegen der häufigen Überimpfungen in verschiedenen Laboren eine verminderte Vitalität besaßen und deswegen auch auf dem TC-Medium nicht mehr sehr gut wachsen konnten. Die Kolonien fast aller $X c p$-Stämme waren auf dem Medium sehr ähnlich, nämlich leicht konvex, gelblich bis gelb und rundlich bis rund mit einem Durchmesser von 3 - 6 mm.

Ein Vergleich der beiden neuen semiselektiven Medien für Xcp ergibt:

Die Vorteile des TC-Mediums sind eine sehr hohe Selektivität und das schnelle Wachstum von $X c p$. Die geprüften anderen Bakterienarten konnten auf dem Medium überhaupt nicht wachsen. Ein Nachteil ist, dass 5-Fluorouracil eine gewisse karzinogene Wirkung hat. Bei der Medienbereitung sollte sehr vorsichtig gearbeitet werden. Es ist etwas mühsam, das Medium vorzubereiten.

Das MD5A-Medium ist leicht herzustellen und erlaubt eine gute Differenzierbarkeit von Xcp-Kolonien. Es enthält keine gefährlichen Substanzen. Ein Nachteil ist das langsame Wachstum von Xcp. Da die Selektivität nicht 100\% beträgt, bilden die Saprophyten evtl. eine Gefahr, die $X c p$-Kolonien nicht immer zu erkennen.

Durch weitere Modifikationen des MD5A-Mediums könnte evtl. die Wachstumsgeschwindigkeit von Xcp gefördert werden, indem z. B. andere Antibiotika eingesetzt oder die Antibiotikakonzentrationen geändert werden. 


\section{ZUSAMMENFASSUNG}

1. Die Eignung zahlreicher semiselektiver Nährmedien für den sicheren und schnellen Nachweis von Xanthomonas campestris pv. pelargonii $(=X c p)$ wurde untersucht, um latent im Vermehrungsmaterial der Pelargonien in geringen Konzentrationen vorkommende Bakterien nachweisen zu können. Die meisten der getesteten Medien erwiesen sich für diesen Zweck als untauglich.

2. Es wurden 2 neue semiselektive Medien für $X c p$ entwickelt, das TC-Medium und das MD5A-Medium.

3. Das TC-Medium (= Tween-Cellobiose-Medium) hat folgende Zusammensetzung (g/liter): Pepton 10,0, $\mathrm{KBr} 10,0, \mathrm{CaCl}_{2}$ 0,25, $\mathrm{H}_{3} \mathrm{BO}_{3}$ 0,30, Bacto-Agar 16,0. Der pH-Wert wird auf 7,4 vor dem Autoklavieren eingestellt. Bei $55^{\circ} \mathrm{C}$ werden dem Liter Grundmedium aseptisch hinzugefügt: Cellobiose 10 g, Tween 8010 ml, Cycloheximid 50 mg, Cephalexin 65 mg, 5-Fluorouracil 3,0 mg, Tobramycin 1,4 mg.

4. Die Vorteile des TC-Mediums sind eine hohe Selektivität mit einer sehr guten Differenzierbarkeit der Kolonien von Xcp wegen des Gehaltes von Borsäure und der Antibiotika. Die Wiederfindungsrate von $X c p$ nach Zugabe zum Pflanzenextrakt betrug um 100\%. Die $X c p$-Kolonien sind leicht konvex, glänzend. Anfangs sind sie weißlich, dann werden sie gelblich. Später, je nach Isolat, ändert sich die Farbe von gelblich bis gelb. Die Form ist meist rund, umgeben von einem schwachen Hof, der durch die Lipaseaktivität verursacht wird. Pseudomonas fluorescens, Pseudomonas syringae pv. syringae und Erwinia herbicola, die als Begleitflora bei Pelargonien vorkommen können, vermochten auf dem neuen Nährmedium nicht zu wachsen. Ein Nachteil ist, dass 5-Fluorouracil eine gewisse karzinogene Wirkung hat. Bei der Medienbereitung sollte sehr vorsichtig gearbeitet werden.

5. Das MD5A-Medium hat folgende Zusammensetzung (g/liter): $\mathrm{K}_{2} \mathrm{HPO}_{4}$ 3,0, $\mathrm{NaH}_{2} \mathrm{PO}_{4}$ 1,0, $\mathrm{NH}_{4} \mathrm{Cl}$ 1,0, $\mathrm{MgSO}_{4}$ x 7 $\mathrm{H}_{2} \mathrm{O}$ 0,3, Bacto Agar 17,0, $\mathrm{H}_{2} \mathrm{O}$ bidest. 1000 ml. Der pH-Wert wird auf 7,2 vor den Autoklavieren eingestellt. Bei $55^{\circ} \mathrm{C}$ werden dem Liter Grundmedium aseptisch hinzugefügt: Cellobiose 10,0 g, Cycloheximid 0,2 mg, L-Glutaminsäure 5,0 mg, 
L-Methionin 1,0 mg, Cephalexin 10,0 mg, Bacitracin 10,0 mg, Aztreonam 0,4 mg, Bromthymolblau 30,0 mg.

6. Das MD5A-Medium wird als alternatives Medium zur Isolierung von $X c p$ empfohlen, weil es kein 5-Fluorouracil enthält. Obwohl auf dem MD5A-Medium $P$. syringae und $P$. fluorescens wachsen konnten, war eine Differenzierung von Xcp auf Grund des unterschiedlichen Koloniephänotyps leicht möglich. Durch die Zugabe von 0,4 mg/l Aztreonam wurde das Wachstum von E. herbicola völlig unterdrückt. Ein Nachteil war das langsame Wachstum von Xcp im Vergleich zum TC-Medium. 
KAPITEL II

EPIDEMIOLOGISCHE UNTERSUCHUNGEN ZUM LATENTEN BEFALL

\section{EINLEITUNG}

Innerhalb des Zierpflanzenbaus nimmt die Pelargonie mit Abstand den größten Markanteil ein und verzeichnet gleichzeitig die höchste jährliche Umsatzsteigerung. In der Bundesrepublik werden jährlich rund 120 Millionen, in der EU schätzt man zwischen 300 und 400 Millionen Pflanzen, vermehrt und verkauft. Diese im Wachstum begriffenen Produktionszahlen bekunden den Pelargonien ihre herausragende Stellung im deutschen Zierpflanzenbau und ihre große Beliebtheit beim Verbraucher (GANNINGER-HAUCK, 1993; GANSLMEIER, 1987; PHYTOTEST, 1993).

Pelargonien werden der Familie der Storchschnabelgewächse (Geraniaceae) zugeordnet und lassen sich in die Stammarten Pelargonium zonale-Hybriden und P. peltatumHybriden einteilen. "Zonale“-Pelargonien haben leicht verholzende Stengel und eine als Gürtel sichtbare braune Zone auf der Blattspreite. Die schwach flaumigen Stengel der "Peltatum“-Pelargonien sind dünn, niederliegend oder hängend. Sie werden daher auch „Hänge-Pelargonien oder -Geranien“ genannt. Beheimatet sind Pelargonien im südlichen Afrika, von wo aus erste Pflanzen der Gattung Pelargonium vermutlich 1632 nach Europa eingeführt wurden (LAUGHNER, 1993). Heute sind etwa 250 Pelargonium-Arten bekannt. Rund 10.000 verschiedene Pelargoniensorten werden gehandelt, deren Sortiment ständig im Fluss ist. Neben der Erhaltung sortenspezifischer Eigenschaften ist die Bereitstellung von gesundem Ausgangsmaterial für die Jungpflanzenproduktion entscheidend (FISCHER-TÖHL, 1992; ZIMMER, 1991; DÜMMEN, 1991/92).

Neben abiotischen Faktoren wird die Pelargonie durch eine Vielzahl von Pathogenen gefährdet, wobei dem Bakterium Xanthomonas campestris pv. pelargonii (Xcp) eine herausragende Bedeutung zukommt (KREBS, 1992; BERKELMANN et al., 1994; NAMETH et al., 1999). Die bakterielle Pelargonienwelke ist nahezu weltweit verbreitet. Sie tritt in Amerika und Europa auf und wurde ebenso im Mittleren Osten und in Australien beobachtet (BRADBURY, 1986). Der Erreger wird vor allem durch direkte Kontakte (Schnittwerkzeuge, Hände, Kulturflächen, Bewässerung etc.) von kranken Pflanzen auf gesunde über- 
tragen. Beim Schneiden von Stecklingen gelangt das Bakterium leicht in offene Gefäße, in denen es sich schnell über den gesamten Spross ausbreiten kann. Mit Hilfe einer polaren Geißel ist es in Flüssigkeitsfilmen beweglich und in der Lage, über Wurzeln und Blätter (Hydathoden, Stomata) aktiv in die Wirtspflanze einzudringen (DOUGHERTY et al., 1974). Хср kann besonders dann zu beachtlichen Verlusten (über 50\%) führen, wenn der Erreger über stecklingsvermehrte Pflanzen verbreitet wird.

Die Übertragung und Eindringungsmöglichkeiten sowie die durch den Erreger hervorgerufenen Symptome sind sehr unterschiedlich. Ausführliche Beschreibungen der Symptome lieferten HELLMERS (1952) und MUNNECKE (1954). Kleine, anfänglich wasserdurchtränkte, später nekrotisierende Blattflecken entstehen im Bereich der Stomata, V-förmige chlorotische Symptome vom Blattrand ausgehend charakterisieren das Eindringen des Erregers über Hydathoden und die sogenannte "Schirmwelke“ (Abb. 1) befallener Blätter und Braunverfärbung am Stengel seine systemische Ausbreitung. Insbesondere unter feucht-warmen Bedingungen ist der Krankheitsverlauf sehr schnell und intensiv, so dass es zum vollständigen Zusammenbruch einer Kultur kommen kann (Abb. 2). Um dies zu verhindern, wurden Möglichkeiten zur Unterbrechung der Infektionskette des Erregers untersucht und seit den 70er Jahren sehr arbeitsaufwendige und kostenintensive Gesunderhaltungszyklen in Züchtungs- und Vermehrungsbetrieben etabliert, wodurch die bakterielle Welke in Grenzen gehalten wurde (GRIESBACH et al., 1999).

Das Bakterium ist wirtsspezifisch für Pelargonien (KLEINHEMPEL et al., 1989). Alle Pelargonien sind natürliche Wirtspflanzen für Xcp. Sorten von P. graveolens, P. acerifolium, P. x domesticum (PAGEL, 1993), P. tomentosum sowie P. scarborowiae (WHITE, 1993) weisen Resistenz auf. Bei den am meisten im Zierpflanzenbau verbreiteten $P$. zonaleHybriden und P. peltatum-Hybriden gibt es zwar Unterschiede im Anfälligkeitsgrad, bisher jedoch noch keine resistenten Sorten (MUNNECKE, 1954; STEPHENS \& TUNIER 1989; KREBS et al., 1993; TAYLOR et al., 1996). Von den etwa 250 Pelargonium-Arten wurden bisher ca. 50 auf Resistenz gegen $X c p$ untersucht und auch einige gefunden, die nur wenig oder gar nicht befallen werden (KNAUSS \& TAMMEN, 1967; WAINWRIGHT \& NELSON, 1972; DUNBAR \& STEPHENS, 1989; TAYLOR et al., 1996; GRIESBACH \& TYRACH, 1998). 


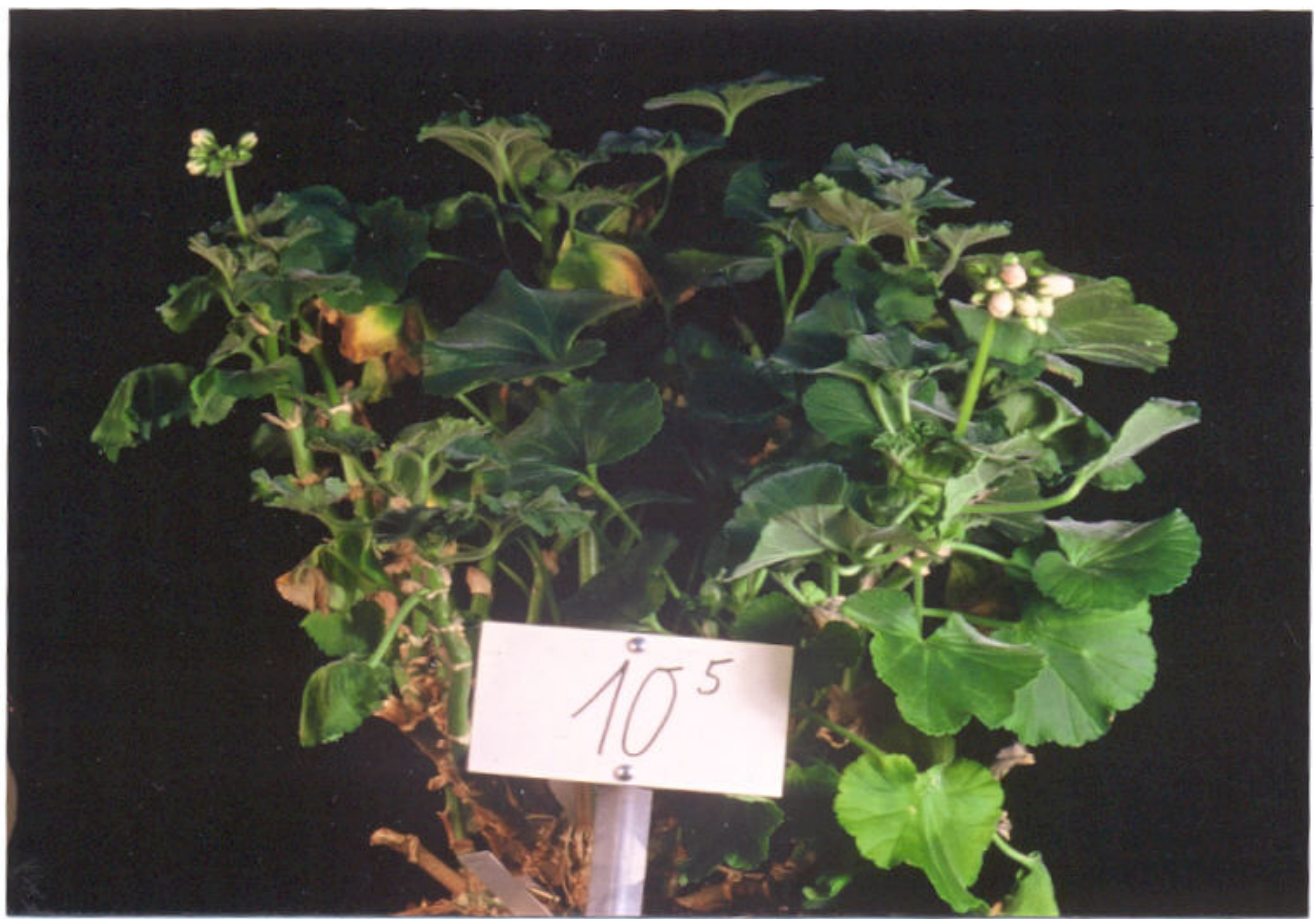

Abb. 1: Anfangssymptome der Blattfleckenkrankheit, besonders typisch sind die Blätter mit "Schirmwelke“ und gelb-braunen Flecken

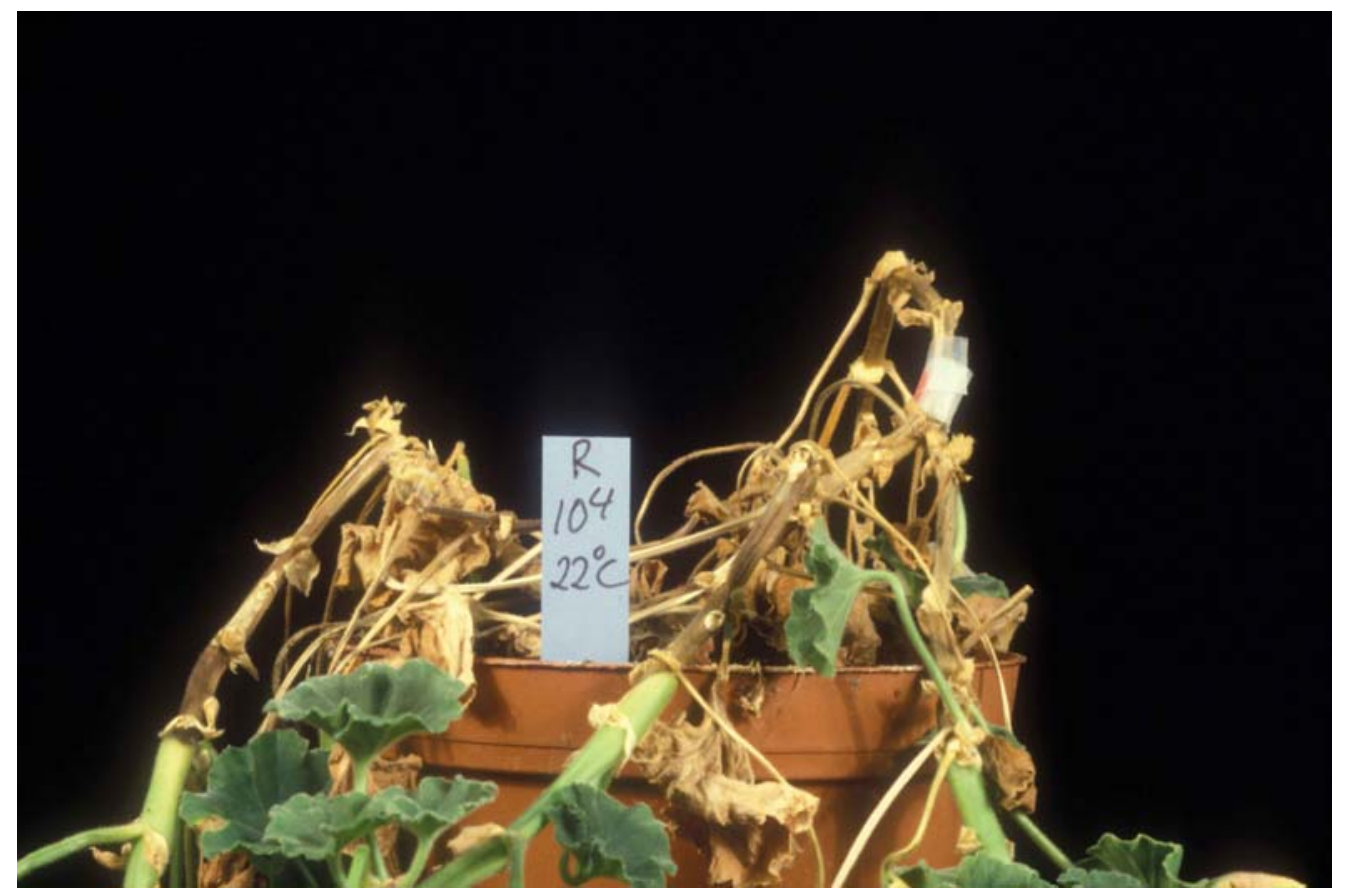

Abb. 2: Totaler Zusammenbruch einer Pflanze, trotzdem sind die Triebspitzen noch grün 
In Jungpflanzenbetrieben werden umfangreiche Vorkehrungen getroffen, um das Kulturrisiko zu minimieren. Durch Gewebekultur vermehrte Pflanzen werden auf völlige Befallsfreiheit auch durch endophytisch lebende, nicht pathogene Organismen getestet. Diese Pflanzen werden zum Aufbau eines „Nuclear-Stock“ verwendet, der in insektensicheren Gewächshäusern aufgezogen wird. Aus dem „Nuclear-Stock“ wird durch vegetative Vermehrung ein „Mother-Stock“ aufgezogen, wobei auf strenge Hygienemaßnahmen geachtet wird. Aus diesem gehen mehrere Generationen eines „Propagation-Stock“ hervor, von dem Stecklinge für die Weiterkultur oder den Verkauf geerntet werden. Die besten Pflanzen des „Nuclear-Stock“ werden jährlich, nachdem umfangreiche Tests auf Virosen und Xcp durchgeführt wurden, zum Aufbau eines neuen „Nuclear-Stock“ verwendet.

Die Bedeutung der bakteriellen Stengelfäule und Blattfleckenkrankheit der Pelargonie ist unumstritten. Da der Erreger $X c p$ bei latentem Auftreten und durch leichte Verwechslung mit Schadbildern anderer Erreger nicht immer einwandfrei anhand der von ihm verursachter Symptome an den Pflanzen identifiziert werden kann, sind spezielle Diagnosemethoden erforderlich, um einen Befall möglichst frühzeitig aufdecken zu können und durch Selektion weitgehendst bakterienfreier Mutterpflanzen eine Übertragung des Erregers bei der vegetativen Vermehrung zu vermeiden. Ein anderer Weg zu bakterienfreiem oder -armem Pflanzenmaterial zu kommen, ist die Gewinnung von Pelargonien aus Samen. Aber auch samenvermehrte Pelargonien sind nicht als völlig befallsfrei einzustufen, doch ist eine Erregerübertragung durch Samen von geringer Bedeutung (HEIMANN, 1973; BRÖTHER 1979, 1981b). BRÖTHER (1981b) konnte nach Untersuchung von 500 Pelargoniensamen nur in 0,2\% der Samen Xcp nachweisen. KOUCHEKI (1973b) fand in 1,8\% der Fälle Xcpinfizierte Pelargoniensamen.

Xcp kann auch heute noch zu einer starken Gefährdung der Pelargonienproduktion führen, da der Erreger mangels wirksamer chemischer Bekämpfungsmittel nur prophylaktisch durch entsprechende Kulturtechnik und Pflanzenhygiene bekämpft werden kann und häufig latentes Auftreten das Erkennen der Krankheit erschwert sowie eine unkontrollierte Verbreitung des Erregers vor allem bei der vegetativen Vermehrung ermöglicht (BACHTHALER, 1973; GRIESBACH et al., 1985).

Im Rahmen dieser Arbeit sollte deshalb das Phänomen der Latenz von $X c p$ in Pelargonienpflanzen näher untersucht werden. Dazu wurden Pflanzen von zwei Pelargoniensorten mit niedriger Inokulumskonzentration inokuliert und das Verhalten der Bakterien in den 
Pflanzen im Gewächshaus und in der Klimakammer verfolgt. Zunächst mussten dafür Antibiotika-resistente Bakterien im Labor selektiert und auf ihre genetische Stabilität in planta und in vitro geprüft werden. Die Ausbreitung der markierten Bakterien wurde in den Stengeln, den Blättern, den Wurzeln, der Erde und im Sickerwasser verfolgt. Außerdem wurde die Auswirkung niedriger und hoher Temperaturen auf den Erreger im Stengel verfolgt und in einem Langzeitversuch über 68 Monate untersucht, wie lange sich die Bakterien unerkannt (latent) in der Pflanze aufhalten konnten. 


\section{MATERIAL UND METHODEN}

\subsection{Chemikalien}

Die verwendeten Chemikalien und Medien wurden, wenn nicht anders angegeben, von den Firmen SIGMA (Deisenhofen), BOEHRINGER (Ingelheim), MERCK (Darmstadt), ROTH (Karlsruhe) und SERVA (Heidelberg) bezogen.

\subsection{Sterilisationstechniken}

Alle Glaswaren, wie Glaspipetten, Erlenmeyerkolben und Reagenzgläser, die für die Herstellung von Medien verwendet wurden, wurden für $4 \mathrm{~h}$ bei $180^{\circ} \mathrm{C}$ im Trockenschrank sterilisiert. Nährmedien und Kunststoffmaterialien wurden im Autoklaven für 20 min bei 121 ${ }^{\circ} \mathrm{C}$ und 1 bar sterilisiert. Empfindliche organische Verbindungen, wie Antibiotika und CQuellen, wurden sterilfiltriert und dem Grundmedium nach dem Autoklavieren und Abkühlen auf $47^{\circ} \mathrm{C}$ zugefügt. Die Sterilfiltration erfolgte durch einen Sterilfilter - bestückt mit einer Zellulose-Acetat-Membran, Porendurchmesser 0,22 $\mu \mathrm{m}$ (Fa. SARTORIUS, Göttingen). Spatel, Ösen und Pinzetten wurden in 70\%igem EtOH gespült und über dem Bunsenbrenner abgeflammt. Alle Arbeiten, die unter sterilen Bedingungen erfolgen mussten, wurden unter Benutzung der sterilen Werkbank (GELAIRE HF 48) durchgeführt.

\subsection{Bakterienstämme}

Für die epidemiologischen Untersuchungen wurde der Stamm „GSPB 2503“ von Xanthomonas campestris pv. pelargonii aus der Göttinger Sammlung Phytopathogener Bakterien verwendet, der von uns auf Resistenz gegen 100 ppm Rifampicin selektiert worden war (Kap. 2.5). Außerdem wurden die Antibiotika-resistenten Stämme GSPB 2400 (resistent gegen 150 ppm Streptomycin) und GSPB 2401 (resistent gegen 100 ppm Rifampicin und 150 ppm Streptomycin) eingesetzt. In Kontrollversuchen wurde der zugehörige Wildstamm GSPB 1955 (Herkunft PAGEL, Fa. ENDISCH) verwendet. 


\section{$2.4 \quad$ Nährmedien}

Die resistenten $X c p$-Stämme wurden in folgenden Nährmedien selektiert:

\subsubsection{Hefeextrakt-Pepton-Natriumchlorid (nach RHODES, 1959)}

Hefeextrakt

$\mathrm{NaCl}$

Pepton

dest. $\mathrm{H}_{2} \mathrm{O}$

$\mathrm{PH}$

$\begin{array}{ll}3,0 & \mathrm{~g} \\ 5,0 & \mathrm{~g} \\ 10,0 & \mathrm{~g} \\ 1000 & \mathrm{ml} \\ 7,2 & \end{array}$

Die gewonnenen Bakterienisolate wurden in Schrägröhrchen mit folgendem Medium für die späteren Versuche aufbewahrt:

\subsubsection{Hefeextrakt-Dextrose-Kalk-Agar (nach LELLIOTT \& STEAD, 1987)}

Hefeextrakt

Glukose

$\mathrm{CaCO}_{3}$

Agar

Bidest. $\mathrm{H}_{2} \mathrm{O}$

pH nicht eingestellt

$\begin{array}{ll}10,0 & \mathrm{~g} \\ 20,0 & \mathrm{~g} \\ 20,0 & \mathrm{~g} \\ 12,0 & \mathrm{~g} \\ 1000 & \mathrm{ml}\end{array}$

$1000 \mathrm{ml}$

Für die Isolationen aus dem Pflanzenmaterial wurden das semiselektive Tween-CellobioseMedium und ein generelles Medium verwendet:

2.4.3 Tween-Cellobiose-Medium (nach BATUR et al., 1994)

$\begin{array}{lll}\text { Pepton } & 10,0 & \mathrm{~g} \\ \mathrm{KBr} & 10,0 & \mathrm{~g} \\ \mathrm{CaCl}_{2} & 0,25 & \mathrm{~g} \\ \mathrm{H}_{3} \mathrm{BO}_{3} & 0,30 & \mathrm{~g}\end{array}$


Bacto-Agar

$16,0 \quad \mathrm{~g}$

Bidest. $\mathrm{H}_{2} \mathrm{O}$

$1000 \mathrm{ml}$

$\mathrm{pH}$

7,4

Nach dem Autoklavieren und Abkühlen auf 45 - $50{ }^{\circ} \mathrm{C}$ wurden aseptisch hinzugefügt:

Tween 80

$10 \mathrm{ml}$

Cellobiose

10,0 g in $\mathrm{H}_{2} \mathrm{O}$

Cycloheximid

50,0 mg in $\mathrm{H}_{2} \mathrm{O}$

Cephalexin

65,0 mg in EtOH

5-Fluorouracil

$12,0 \mathrm{mg}$

Tobramycin

$0,40 \quad \mathrm{mg}$

\subsubsection{NGA-Medium (nach MAVRIDIS)}

Nutrient Broth (Difco oder Oxoid)

$8,0 \quad \mathrm{~g}$

Glukose

$10,0 \quad \mathrm{~g}$

Hefeextrakt

$3,0 \quad \mathrm{~g}$

Agar

$16,0 \quad \mathrm{~g}$

dest. $\mathrm{H}_{2} \mathrm{O}$

$1000 \mathrm{ml}$

$\mathrm{pH}$

7,2

\subsubsection{NGAR-Medium}

Nutrient Broth (Difco oder Oxoid)

$8,0 \quad \mathrm{~g}$

Glukose

$10,0 \quad \mathrm{~g}$

Hefeextrakt

$3,0 \quad \mathrm{~g}$

Agar

$16,0 \quad \mathrm{~g}$

dest. $\mathrm{H}_{2} \mathrm{O}$

$1000 \mathrm{ml}$

$\mathrm{pH}$

7,2

Zutaten autoklavieren und auf $45^{\circ} \mathrm{C}$ abkühlen, anschließend sterilflitrierte Zugabe von:

Rifampicin

100 ppm, in Methanol gelöst

Cycloheximid

100 ppm, in $\mathrm{H}_{2} \mathrm{O}$ gelöst 


\subsubsection{NGAS-Medium}

$\begin{array}{lll}\text { Nutrient Broth (Difco oder Oxoid) } & 8,0 & \mathrm{~g} \\ \text { Glukose } & 10,0 & \mathrm{~g} \\ \text { Hefeextrakt } & 3,0 & \mathrm{~g} \\ \text { Agar } & 16,0 & \mathrm{~g} \\ \text { dest. } \mathrm{H}_{2} \mathrm{O} & 1000 & \mathrm{ml} \\ \mathrm{pH} & 7,2 & \end{array}$

Zutaten autoklavieren und auf $45{ }^{\circ} \mathrm{C}$ abkühlen, anschließend sterilfiltrierte Zugabe von:

Streptomycinsulfat $150 \quad$ ppm, in $\mathrm{H}_{2} \mathrm{O}$ gelöst

\subsubsection{NGARS-Medium}

$\begin{array}{lll}\text { Nutrient Broth (Difco oder Oxoid) } & 8,0 & \mathrm{~g} \\ \text { Glukose } & 10,0 & \mathrm{~g} \\ \text { Hefeextrakt } & 3,0 & \mathrm{~g} \\ \text { Agar } & 16,0 & \mathrm{~g} \\ \text { dest. } \mathrm{H}_{2} \mathrm{O} & 1000 & \mathrm{ml} \\ \text { pH } & 7,2 & \end{array}$

Zutaten autoklavieren, auf $45{ }^{\circ} \mathrm{C}$ abkühlen, anschließend sterilfiltrierte Zugabe von:

Rifampicin

Streptomycinsulfat
100 ppm, in Methanol gelöst

150 ppm, in $\mathrm{H}_{2} \mathrm{O}$ gelöst

Alle Medien wurden nach dem Autoklavieren unter Benutzung der Werkbank in Petrischalen $(\varnothing 9 \mathrm{~cm})$ ausgegossen.

\subsection{Gewinnung von Antibiotika-resistenten Mutanten}

Um in unseren Untersuchungen das latent vorkommende Bakterium leicht isolieren zu können, wurde eine Antibiotika-resistente Mutante von Xcp hergestellt. Zur Herstellung der Mutante wurde der Bakterienstamm Nr. 1955 aus der Göttinger Sammlung Phytopathogener Bakterien (GSPB) in eine Vorkultur (30 ml Rhodes-Nährlösung) mit einer sterilen Impföse direkt von dem Schrägröhrchen beimpft. Die Vorkultur wurde für $1 \mathrm{~d}$ bei 25 - $28{ }^{\circ} \mathrm{C}$ und bei $110 \mathrm{U} / \mathrm{min}$ auf einem Rundschüttler (Modell IRC-1-U, Fa. Kühner, Basel) 
inkubiert. Für die Hauptkultur wurden 2 x 300 ml Rhodes-Nährlösung mit jeweils 5 ml aus der Vorkultur beimpft und $1 \mathrm{~d}$ bei den gleichen Bedingungen auf dem Schüttler inkubiert. Nachdem die Kulturen gut gewachsen waren, wurde einem Erlenmeyer-Kolben 20 ppm (Endkonzentration) steril filtriertes Rifampicin zugefügt. Der zweite Erlenmeyer-Kolben wurde zur Kontrolle ohne Antibiotikum belassen. Die Kulturen wurden dann 2 weitere Tage unter den oben genannten Bedingungen auf dem Schüttler inkubiert. Danach wurden $2 \mathrm{x}$ 300 ml Rhodes-Nährlösung mit 5 ml aus der Hauptkultur beimpft. Der ersten Kultur wurden nun 40 ppm steril filtriertes Rifampicin zugefügt. So wurden schließlich RifampicinMutanten gewonnen, die gegen 60, 80 und schließlich 100 ppm Rifampicin (GSPB 2503) resistent waren. Genauso wurde eine gegen 150 ppm Streptomycin (GSPB 2400) resistente Mutante gewonnen. Bei dem ersten Vorgang wurden 25 ppm Streptomycin hinzugefügt, und bei den darauf folgenden Schritten wurden die Dosen des Antibiotikums auf 50, 75, 100 und 150 ppm erhöht.

In einem weiteren Versuch wurde eine Doppelmutante, mit Toleranz gegen 150 ppm Streptomycin und 100 ppm Rifampicin (GSPB 2401) gewonnen. Um die Bakterien gegen die Antibiotika zu selektieren, wurden 2 x 300 ml Rhodes-Nährlösung mit jeweils $5 \mathrm{ml}$ aus der Vorkultur beimpft. Nach Bewachsen der Kultur wurden 20 ppm sterilfiltriertes Rifampicin plus 20 ppm Streptomycin zugegeben. Durch graduelle Erhöhung der Antibiotikakonzentrationen wurde schließlich eine gegen 100 ppm Rifampicin und 150 ppm Streptomycin resistente Mutante hergestellt.

Nach jedem Schritt wurde eine Verdünnungsreihe hergestellt und in Petrischalen mit NGA-Agar, der die gleiche Antibiotikakonzentration wie das Flüssigmedium enthielt, und auf NGA-Medium ausplattiert. Nach 2 - 3 d bei $25{ }^{\circ} \mathrm{C}$ im Brutschrank wurden typische einzelne Kolonien ausgesucht und auf Schrägröhrchen mit Hefeextrakt-Dextrose-KalkAgar bei $10^{\circ} \mathrm{C}$ kühl aufbewahrt. Gleichzeitig wurde der Antibiotika-resistente $X c p$-Stamm lyophilisiert.

\subsubsection{Stabilität des Antibiotika-resistenten Stammes in planta}

Die Mutante (GSPB 2503) wurde in planta geprüft, um eine eventuelle Rückmutation des Antibiotika-resistenten Stammes und / oder einen Verlust seiner Pathogenität zu überprüfen (RUSSELL, 1975). Je 2 Pelargonienpflanzen der Sorten "Isabell“ und "Rosario“ wur- 
den mit dem Antibiotika-resistenten Stamm inokuliert. Zur Kontrolle wurden zwei Pflanzen mit dem Wildstamm (GSPB 1955) inokuliert. Zur Inokulation der Pflanzen wurde eine Glasspritze (Hero Injektionskanüle, Nr. G 18) verwendet. Zwischen jeder Injektion wurde die Injektionskanüle mit 70\% EtOH sterilisiert und dann mit Leitungswasser gespült. Die behandelten Pflanzen wurden im Gewächshaus bei $25{ }^{\circ} \mathrm{C}$ und einer relativen Luftfeuchte von 60 - 70\% aufgestellt. Nach zwei Wochen wurden die Bakterien aus dem Stengel zurückisoliert. Die Pflanzenproben wurden in 0,01 $\mathrm{M} \mathrm{MgSO}_{4}$-Lösung zermörsert, und vom Homogenat wurden Verdünnungsreihen hergestellt. Aus jeder Verdünnungsstufe wurden jeweils 0,1 ml auf das NGA-Medium und das NGAR-Medium ausplattiert und $3 \mathrm{~d}$ bei 25 ${ }^{\circ} \mathrm{C}$ im Brutschrank inkubiert. Nach dem Auszählen der Kolonien wurde die Lebendkeimzahl pro Gramm Frischstengelgewicht berechnet.

\subsection{Herkunft und Anzucht der Pelargonien}

Die Versuchspflanzen wurden von Herrn Dr. Pagel (Fa. Geranien Endisch, Hagenbach) als bewurzelte Stecklinge zur Verfügung gestellt und in Plastiktöpfe $(\varnothing 15 \mathrm{~cm})$ mit Einheitserde-Sand-Kompost im Verhältnis 2:1:2 gepflanzt. Es wurden zwei Pelargoniensorten eingesetzt: "Rosario“ (anfällig) und “Isabell“ (etwas weniger anfällig).

\subsection{Anzucht der Bakterien}

Zur Anzucht der Bakterien wurde der Stamm GSPB 2503 mit einer sterilen Impföse direkt vom Schrägröhrchen auf das NGA-Medium geimpft und im Brutschrank 2 - 3 d bei $25{ }^{\circ} \mathrm{C}$ inkubiert. Von einer typischen Kolonie wurde mit einer halbvollen Impföse ein Erlenmeyer-Kolben mit $25 \mathrm{ml}$ Rhodes-Medium beimpft und für $1 \mathrm{~d}$ bei $25^{\circ} \mathrm{C}$ und $110 \mathrm{U} / \mathrm{min}$ auf einem Rundschüttler inkubiert. Nach einer Zentrifugation von 10 min bei ca. 3000 g wurde

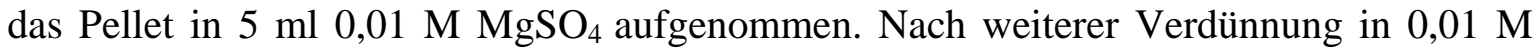
$\mathrm{MgSO}_{4}$ wurde die optische Dichte (OD) der Bakteriensuspension in einer $1 \mathrm{~cm}$ Küvette spektralphotometrisch (BAUSCH \& LOMB, Spectronic 20) bei $660 \mathrm{~nm}$ auf 0,06 eingestellt. In dieser Suspension waren ca. $10^{8} \mathrm{cfu} / \mathrm{ml}$ enthalten. 


\subsection{Einfluss der Temperatur auf die Vermehrung und Latenz von $X c p$ in planta}

Diese Versuche wurden in Kooperation mit Frau Dr. Brielmaier-Liebetanz, Biologische Bundesanstalt für Land- und Forstwirtschaft (Braunschweig) durchgeführt, wo die Pflanzen in Temperatur-konstanten Gewächshauskabinen $\left(25^{\circ} \mathrm{C}\right.$ und $\left.15^{\circ} \mathrm{C}\right)$ aufgestellt wurden. Die Lichtintensität betrug 6000 lux in Pflanzenhöhe.

\subsubsection{Inokulation von zwei Pelargoniensorten mit dem Antibiotika-resistenten Stamm}

Zur Inokulation wurden am 08. 01. $1996 \mathbf{1 0} \boldsymbol{\mu l}$ einer frischen Suspension der Antibiotikaresistenten Mutante (siehe 2.7) in Konzentrationen von $10^{5}, 10^{4}$ oder $10^{3} \mathrm{cfu} / \mathrm{ml}$ (genaue Konzentrationsbestimmung in Kap. 3.2) in die Stengel mit einer sehr feinen Injektionsnadel (Unimetrics coorporation 1-TP9050R) inokuliert. Von den beiden Pelargoniensorten "Rosario“ und "Isabell“ wurden jeweils 40 Pflanzen mit jeder der drei Konzentrationen inokuliert. Zum Zeitpunkt der Inokulation waren die Pflanzen etwa 15 - $20 \mathrm{~cm}$ hoch, und etwa $20 \%$ besaßen Seitentriebe. Die Inokulationsstelle befand sich ca. $10 \mathrm{~cm}$ über dem Erdboden. Vor der Inokulation wurden von jeder Bakteriensuspension $100 \mu \mathrm{l}$ auf NGA und NGAR-Medium viermal ausplattiert, um die Antibiotikaresistenz des Isolats zu überprüfen. Nach jeder Injektion wurde die Injektionskanüle zweimal mit 70\% EtOH sterilisiert und anschließend mit Leitungswasser gespült. Die Inokulationsstellen wurden zuerst mit einem Etikett beklebt und dann mit Parafilm umwickelt. Als Kontrolle wurden jeweils 15 Pflanzen mit $\mathrm{H}_{2} \mathrm{O}$ inokuliert. Anschließend wurden die Pflanzen im Gewächshaus bei 25 ${ }^{\circ} \mathbf{C}$ und einer relativen Luftfeuchte von 60 - 70\% aufgestellt. Die gleiche Zahl ähnlich inokulierter Pelargonienpflanzen wurde im Gewächshaus bei $15{ }^{\circ} \mathbf{C}$ und 50 - 60\% relativer Luftfeuchte aufgestellt. Die Entwicklung typischer Krankheitssymptome wurde regelmäßig registriert und die Vermehrung und Ausbreitung der Bakterien innerhalb der Pflanzen durch Isolationen zu bestimmten Terminen bestimmt. 


\subsubsection{Versuchsaufbau}

Der Versuch bestand zunächst aus 12 inokulierten Versuchsgliedern (Tab. 1) von jeweils 40 Pflanzen:

Tab. 1: Übersicht über die Versuchsglieder

\begin{tabular}{|c|c|c|c|c|c|}
\hline \multirow[t]{2}{*}{ Nr. } & \multirow{2}{*}{$\begin{array}{l}\text { Inokulum- } \\
\text { Konzentration }\end{array}$} & \multicolumn{2}{|c|}{ "Isabell" } & \multicolumn{2}{|c|}{ "Rosario" } \\
\hline & & $25^{\circ} \mathrm{C}$ & $15^{\circ} \mathrm{C}$ & $25^{\circ} \mathrm{C}$ & $15^{\circ} \mathrm{C}$ \\
\hline 1 & $10^{5}$ & $X$ & & & \\
\hline 2 & $10^{5}$ & & $X$ & & \\
\hline 3 & $10^{5}$ & & & $\mathrm{X}$ & \\
\hline 4 & $10^{5}$ & & & & $\mathrm{X}$ \\
\hline 5 & $10^{4}$ & $X$ & & & \\
\hline 6 & $10^{4}$ & & $\mathrm{X}$ & & \\
\hline 7 & $10^{4}$ & & & $\mathrm{X}$ & \\
\hline 8 & $10^{4}$ & & & & $X$ \\
\hline 9 & $10^{3}$ & $\mathrm{X}$ & & & \\
\hline 10 & $10^{3}$ & & $\mathrm{X}$ & & \\
\hline 11 & $10^{3}$ & & & $\mathrm{X}$ & \\
\hline 12 & $10^{3}$ & & & & $\mathrm{X}$ \\
\hline 13 & Wasser-Kontr. & $X$ & & & \\
\hline 14 & Wasser-Kontr. & & $\mathrm{X}$ & & \\
\hline 15 & Wasser-Kontr. & & & $\mathrm{X}$ & \\
\hline 16 & Wasser-Kontr. & & & & $\mathrm{X}$ \\
\hline
\end{tabular}

$\mathrm{X})=$ jeweils 40 Pflanzen

Sechs Monate nach der Inokulation, d. h. am 03. 07. 1996, wurde jeweils die Hälfte der noch verbliebenen Pflanzen von jedem Versuchsglied in die Kabine mit der jeweils anderen Temperatur transferiert, d. h von $25^{\circ} \mathrm{C}$ nach $15{ }^{\circ} \mathrm{C}$, und von $15^{\circ} \mathrm{C}$ nach $25^{\circ} \mathrm{C}$. Am 15 . 12. 1997 wurden die restlichen Versuchspflanzen nach Göttingen gebracht und dort wieder bei $25^{\circ} \mathrm{C}$ und $15^{\circ} \mathrm{C}$ aufgestellt.

Düngung: Bis zum August 1998 wurden die Pflanzen nach Bedarf (etwa alle 2 Monate) mit 1\% Hakaphos gedüngt. Danach wurden die Pflanzen wöchentlich gedüngt. 
Das folgende Schema zeigt den Versuchsaufbau, der in gleicher Weise für die beiden Versuchssorten "Isabell“ und "Rosario" und die 3 Inokulumskonzentrationen durchgeführt wurde.

Inokulation: 08. 01. 1996: Biologische Bundesanstalt für Land- und Forstwirtschaft, Braunschweig

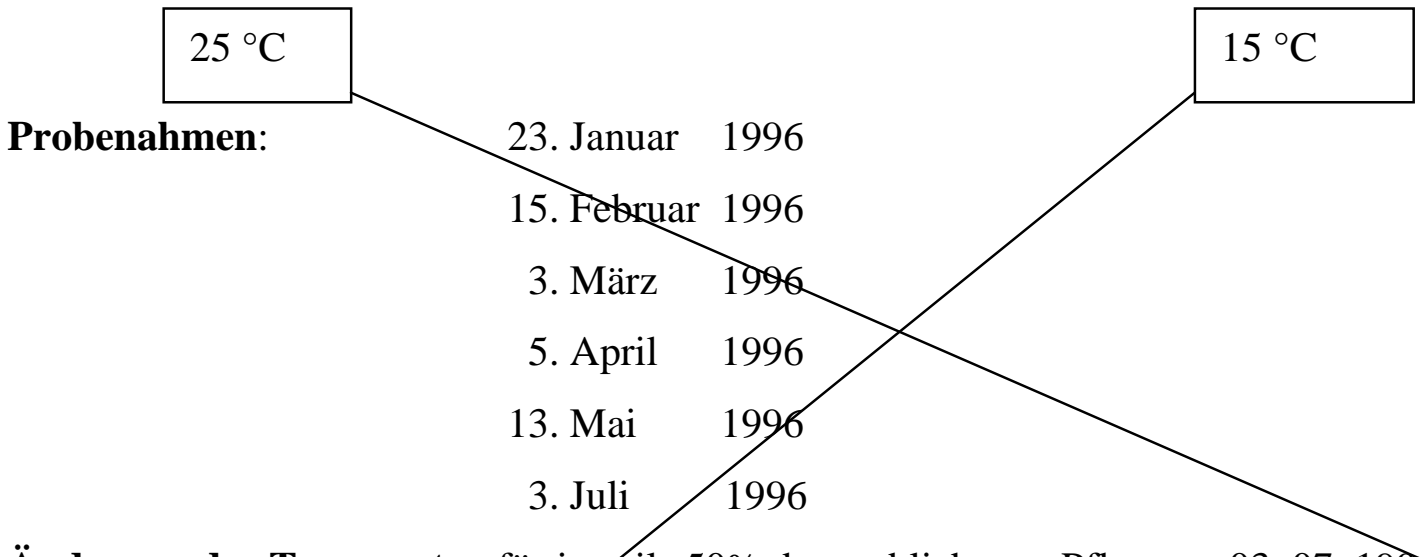

Änderung der Temperatur für jey reils 50\% der verbliebenen Pflanzen: 03. 07. 1996

$$
25^{\circ} \mathrm{C}
$$

$$
15 / 25^{\circ} \mathrm{C}
$$

\section{Probenahmen:}
14. August
10. September
7. Oktober
5. November
10. Dezember
7. Oktober
12. November
9. Dezember
1996
1996
1996
1996
1996
1997
1997
1997

Transfer nach Göttingen: 15. 12. 1997

$25^{\circ} \mathrm{C}$ : Schwankungen im Sommer zeitweise deutlich höher als $25{ }^{\circ} \mathrm{C}$

$$
25^{\circ} \mathrm{C}
$$

$$
15 / 25^{\circ} \mathrm{C}
$$

\section{$15^{\circ} \mathrm{C}$}

$25 / 15{ }^{\circ} \mathrm{C}$

Probenahmen:

22. Mai

1999

14. Oktober

1999

11. November 1999

9. April

2000

15. Mai

2000

22. Juni

2000

9. Juli

2000

29. September 2000

29. Oktober 2000

10. September 2001

$15{ }^{\circ} \mathrm{C}$ : Sehr konstante Temperatur

$15^{\circ} \mathrm{C}$ $25 / 15^{\circ} \mathrm{C}$ 


\subsubsection{Gewinnung von Pflanzenextrakten zum Nachweis der Bakterien}

Bei diesen Versuchen wurden die gesamten Pflanzen segmentiert, um festzustellen, wo die Bakterien in der Pflanze waren, und wie hoch die Bakterien sich in der Pflanze ausgebreitet hatten.

Die Pflanzen ohne Wurzeln wurden in Teilen von $2 \mathrm{~cm}$ segmentiert. Jedes Segment wurde numeriert und das Frischgewicht bestimmt. Die Proben wurden oberflächlich mit 70\%igem EtOH sterilisiert, kurz abgeflammt und dann mit einem sterilen Skalpell in kleinere Stücke zerschnitten. Die Proben wurden je nach Größe in 1 - 2 ml $\mathrm{MgSO}_{4}$-Lösung zermörsert. Aus Verdünnungsreihen wurden 0,1 ml auf NGA und auf NGAR- Medium ausplattiert und $2 \mathrm{~d}$ bei $25{ }^{\circ} \mathrm{C}$ inkubiert. Nach dem Auszählen der Kolonien wurde die Lebendkeimzahl pro Gramm Frischgewicht Pflanzengewebe berechnet.

Zur Isolation der Bakterien aus den Wurzeln wurde die gesamte Pflanze aus dem Plastiktopf herausgenommen und mit Leitungswasser die Erde von den Wurzeln entfernt. Je nach Länge wurden die Wurzeln etwas gekürzt. Anschließend wurde das Frischgewicht bestimmt. Die Wurzeln wurden kurz in 70\%iges EtOH getaucht, mit einem sterilen Skalpell in kurze Stücke geschnitten und in 1 - $5 \mathrm{ml} \mathrm{MgSO}_{4}$-Lösung zermörsert. Aus Verdünnungsreihen wurden $0,1 \mathrm{ml}$ auf NGA und auf NGAR- Medium ausplattiert und $2 \mathrm{~d}$ bei $25^{\circ} \mathrm{C}$ im Brutschrank inkubiert.

Zur Isolation aus dem Kultursubstrat wurden 5 g Erde ohne Wurzelreste aus verschiedenen Stellen des Topfes entnommen, gemischt und mit steriler 0,01 $\mathrm{M} \mathrm{MgSO}_{4}$-Lösung durch eine mehrschichtige Baumwollgaze gefiltert. Das in einem Becherglas gesammelte Wasserfiltrat wurde durch Zentrifugation (Tischzentrifuge, Fa. Sigma 3-1) bei $6000 \mathrm{x}$ g für 15 min pelletiert. Das Pellet wurde in $1 \mathrm{ml}$ steriler 0,01 $\mathrm{MgSO}_{4}$-Lösung aufgenommen, 1:10 verdünnt und auf NGA und NGAR-Medium ausplattiert.

\subsubsection{Auswertung des Krankheitsbefalls}

Während des gesamten Versuchszeitraums (4,5 Jahre) wurde zu verschiedenen Terminen bonitiert und jeweils der prozentuale Anteil der erkrankten Pflanzen ausgerechnet. Im Verlaufe dieses Langzeitversuches wurden mehrfach gesunde Versuchspflanzen entnommen, um das Vorkommen latent vorhandener Bakterien zu überprüfen. Dadurch wurden dem Versuch sehr früh Pflanzen ohne Symptome entzogen. Wenn danach zusätzliche Pflanzen 
erkrankten, musste deren Anteil auf die zum letzten Termin noch vorhandenen gesunden Pflanzen hochgerechnet werden. Nach diesem Verfahren wurde zu jedem Boniturtermin, gestützt auf die gezählten kranken Pflanzen, ein entsprechender Anteil kranker Pflanzen für die bis dahin ausgeschiedenen gesunden Pflanzen ermittelt und zu den aktuell erkrankten Pflanzen addiert.

\subsection{Untersuchungen zu möglichen Infektionswegen}

Als hauptsächliche Quelle einer Xcp-Infektion werden infizierte Mutterpflanzenbestände, bakterienkontaminierte Stecklingsmesser und verseuchtes Kultursubstrat angesehen (BRÖTHER, 1981a). Hier sollte überprüft werden, über welche Eintrittspforten die Bakterien in das Innere der Pflanzen gelangen und dadurch Symptome hervorrufen können.

\subsubsection{Infektion über das Blatt}

Bei anderen pflanzenpathogenen Bakterien ist schon lange eine epiphytische Vermehrung auf gesunden Pflanzen bekannt (CROSSE, 1959).

In diesem Versuch wurden $100 \mu \mathrm{l}$ von einer $X c p$-Suspension $\left(10^{8} \mathrm{cfu} / \mathrm{ml}\right)$ an 10 Pelargonienpflanzen der Sorte „Rosario“ auf die Blätter getropft. Die Pflanzen wurden in der Klimakammer bei $20^{\circ} \mathrm{C}$ und $80 \%$ Luftfeuchtigkeit aufgestellt. Es sollte festgestellt werden, wie lange die Bakterien epiphytisch auf dem Blatt leben können, und ob sie über das Blatt durch den Blattstiel die Pflanze systemisch befallen und eine Stengelfäule verursachen können.

Für den Nachweis der Bakterien wurden Blätter und Blattstiele getrennt in $10 \mathrm{ml} \mathrm{0,01} \mathrm{M}$ $\mathrm{MgSO}_{4}$ geschüttelt. In der überstehenden Waschflüssigkeit sowie in den Homogenaten von Blättern und Blattstielen, die zum Schluss hergestellt wurden, wurde die Bakterienkonzentration durch Verdünnungsreihen und Ausplattieren bestimmt.

\subsubsection{Infektion über die Schnittstelle}

Das Auftreten der durch $X c p$ verursachten bakteriellen Pelargonienwelke wird stark durch vegetative Vermehrungsmethoden begünstigt. Zur Überprüfung dieses Infektionsweges wurden von gesunden Mutterpflanzen $10 \mathrm{~cm}$ große Stecklinge gewonnen. Auf die Schnittstellen wurden $10 \mu \mathrm{l}$ der Bakteriensuspension $\left(10^{3}\right.$ oder $\left.10^{4} \mathrm{cfu} / \mathrm{ml}\right)$ getropft. Nachdem die 
Bakteriensuspension eingezogen war, wurden die Stecklinge in Töpfe mit Komposterde eingetopft und in der Klimakammer bei $20{ }^{\circ} \mathrm{C}$ und $80 \%$ Luftfeuchtigkeit aufgestellt. Dieser Versuch wurde am 09. 08. 1998 angesetzt.

\subsubsection{Infektion über die Wurzeln}

Hier wurden bei 6 Pelargonienpflanzen der Sorte "Rosario“ die Wurzeln an der Spitze kurz abgeschnitten, 5 min in eine Bakteriensuspension mit $10^{3}, 10^{4}$ oder $10^{5} \mathrm{cfu} / \mathrm{ml}$ getaucht und wieder eingetopft. Die inokulierten Pflanzen wurden bei $25^{\circ} \mathrm{C}$ im Gewächshaus aufgestellt und fast ein Jahr lang einmal in der Woche bonitiert.

\subsubsection{Untersuchungen mit Stecklingen aus latent infizierten Mutterpflanzen}

Aus den Pflanzen, die über das Blatt (2.9.1) oder die Schnittstelle (2.9.2) inokuliert worden waren, wurden am 25. 06. 1999 neue, 10 - 20 cm große Tochterstecklinge gewonnen. Vor dem Einpflanzen der Tochterstecklinge wurden von der Basis mit einem sterilen Skalpell 2 - $3 \mathrm{~mm}$ dünne Scheibchen abgeschnitten. Die dünnen Scheibchen wurden in $70 \% \mathrm{EtOH}$ sterilisiert, kurz abgeflammt und dann in 2 - $3 \mathrm{ml}$ TC-Lösung für $24 \mathrm{~h}$ bei $25^{\circ} \mathrm{C}$ und 110 U/min geschüttelt. Anschließend wurden direkt vom Überstand 0,1 ml auf NGAR und NGA-Medium mehrfach ausplattiert und $2-3 \mathrm{~d}$ bei $25^{\circ} \mathrm{C}$ inkubiert. Die Ergebnisse sind in Kapitel 3.4.3, Tabelle 22 beschrieben.

Die Stecklinge wurden in Jiffy Töpfe ( $\varnothing 5,5$ x 5 cm) mit Komposterde gepflanzt und in der Klimakammer bei $20^{\circ} \mathrm{C}$ aufgestellt. Nach der Wurzelbildung wurden sie umgetopft.

Mit diesen Versuchen sollte festgestellt werden, ob eine Bakterienübertragung von einer latent befallenen Mutterpflanze auf die von ihr gewonnenen Stecklinge erfolgen kann. Dieser Versuch verlief über einen Zeitraum von mehr als 16 Monaten.

Ein zweiter Teil der Proben wurde in TC-Lösung bei $25^{\circ} \mathrm{C}$ und $110 \mathrm{U} / \mathrm{min}$ für 24 - $48 \mathrm{~h}$ inkubiert. Mit dem Überstand wurden Petrischalen mit NGA-, NGAR-Medium und TCMedium beimpft, die anschließend für 2 - $3 \mathrm{~d}$ bei $25^{\circ} \mathrm{C}$ im Brutschrank inkubiert wurden.

\subsubsection{Infektion über das Gieß- und Sickerwasser}

Zur Bestimmung der Bakterienkonzentration im Sickerwasser wurden stark befallene Pelargonienpflanzen von oben etwas übermäßig gegossen. Das durchsickernde Gießwasser 
wurde unten in einem Becherglas aufgefangen. Aus dem gesammelten Sickerwasser wurden 0,1 ml auf NGA und NGAR-Medium 4 mal ausplattiert. Die Inkubation erfolgte wie oben beschrieben. Nach Auszählung der Xcp-Kolonien wurde die Bakterienkonzentration je ml Sickerwasser bestimmt (siehe Kapitel 3.8).

Bodenwasser: Die markierten Bakterien wurden auf NGAR-Medium im Brutschrank frisch (24 h) angezogen, in 0,01 $\mathrm{M} \mathrm{MgSO}_{4}$-Lösung suspendiert, auf eine optische Dichte von 0,6 (ca. $10^{9} \mathrm{cfu} / \mathrm{ml}$ ) eingestellt und anschließend 1:100 (са. $10^{7}$ ) und noch mal 1:1000 (ca. $10^{4}$ ) verdünnt. Von jeder Bakterienkonzentration wurde 1 Liter in jeweils eine Plastikschale $(29$ x 9,5 cm) gegossen. In jede Schale wurden 6 junge eingetopfte Pelargonienpflanzen (ca. 15 cm groß) der Sorte “Rosario“ gestellt. Die Pflanzen wurden in der Klimakammer bei $22{ }^{\circ} \mathrm{C}$ und einer relativen Luftfeuchte von 60 - 70\% aufgestellt. Die Versorgung der Pflanzen mit Wasser erfolgte nur über die Schale, um die Wahrscheinlichkeit zu erhöhen, dass die Bakterien aus dem Wasser in der Schale in die Pflanzen eindrangen.

Gießwasser: Die markierten Bakterien wurden wie oben beschrieben angezogen und auf eine optische Dichte von 0,06 (ca. $10^{8} \mathrm{cfu} / \mathrm{ml}$ ) eingestellt.

In eine Plastikschale (29 x 9,5 cm) wurden 5 Tontöpfe mit je einer kleinen Pflanze gestellt. Nur die in der Mitte der Schale befindliche Pflanze erhielt durch Gießen $4 \mathrm{ml}$ von der frisch angesetzten Bakteriensuspension. Dadurch sollte überprüft werden, ob die direkt behandelte Pflanze erkrankte, und ob später von ihr aus die benachbarten Pflanzen über das Gießwasser von Bakterien befallen wurden. Die Pflanzen wurden in der Klimakammer bei $22{ }^{\circ} \mathrm{C}$ und einer relativen Luftfeuchte von 60 - 70\% aufgestellt und regelmäßig bonitiert.

\subsection{Besiedlung verwandter Unkräuter durch $X c p$}

Es sollte bestimmt werden, inwieweit die Bakterien durch Unkräuter übertragbar sind oder auf Unkräutern in einer epiphytischen Phase längere Zeit überdauern können. Deswegen wurden nur mit den Pelargonien verwandte Unkräuter untersucht und die Arten Erodium cicutorium (Reiherschnabel), Geranium dissectum (Schlitzblättriger Storchschnabel) und Geranium pisillum (Kleiner Storchschnabel) aus der Familie Geraniaceae mit den markierten Bakterien inokuliert. 
Die Samen wurden von Herrn Dr. Steinmann (Zentrum für Umwelt und Landwirtschaft, Universität Göttingen) zur Verfügung gestellt. Die Samen wurden in Kunststofftöpfen (18 x 18) mit einem Einheitserde / Sand-Gemisch (1:1) vorgezogen. Die Pflanzen wurden im Gewächshaus bei $25^{\circ} \mathrm{C}$ und einer relativen Luftfeuchte von 60 - 70\% kultiviert.

\subsubsection{Pikieren und Inokulation der Unkrautkeimlinge}

Die Keimlinge wurden 20 Tage nach der Aussaat pikiert und vereinzelt. Von jedem Unkraut wurden insgesamt 8 Pflanzen in Kunststofftöpfe (13 x 13 x 13) mit einem Einheitserde/Sand-Gemisch gepflanzt. Mit einer Bakteriensuspension von $10^{8} \mathrm{cfu} / \mathrm{ml}$ (GSPB 2503) wurden die Stengel (durch Impfkanüle) und Blätter (durch Sprüher) inokuliert. Die Pflanzen wurden im Gewächshaus bei $25{ }^{\circ} \mathrm{C}$ und einer relativen Luftfeuchte von 60 - 70\% aufgestellt. 


\section{ERGEBNISSE}

\subsection{Stabilität und Virulenz des Antibiotika-resistenten Xcp-Stammes in planta}

Die Pelargoniensorten "Isabell" und "Rosario" wurden mit 3 selektierten Antibiotikaresistenten Xcp-Stämmen (GSPB 2503, 2400 und 2401) und dem Wildstamm (GSPB 1955) im Gewächshaus inokuliert. Vierzehn Tage nach der Inokulation zeigten sich bereits deutliche Symptome, und nach zwanzig Tagen wurden die resistenten $X c p$-Stämme aus inokulierten Stengeln zurückisoliert. Die Versuchsergebnisse deuteten nicht auf ein Rückmutieren der markierten Bakterien zum Antibiotika-sensitiven Wildstamm hin (Tab. 2), da auf dem NGA-Medium nicht deutlich mehr Bakterien gefunden wurden als auf den Antibiotika-haltigen Medien.

Tab. 2: Überprüfung der Stabilität von 3 Antibiotika-resistenten Xcp-Stämmen nach 20tägigem Verbleib im Pelargonienstengel durch Bestimmung der Konzentration im Stengel nach Ausplattierung auf Antibiotika-haltigen Nährmedien im Vergleich mit dem NGAMedium ohne Antibiotikum-Zusatz

\begin{tabular}{l|l|l|l|l}
\hline Mutante & NGA & $\begin{array}{l}\text { NGAR- } \\
\text { Medium }\end{array}$ & $\begin{array}{l}\text { NGAS- } \\
\text { Medium }\end{array}$ & $\begin{array}{l}\text { NGASR- } \\
\text { Medium }\end{array}$ \\
\hline \hline a) GSPB Nr. 2503 & $2,5 \times 10^{7}$ & $2 \times 10^{7}$ & & \\
\hline b) GSPB Nr. 2400 & $5 \times 10^{6}$ & & $2 \times 10^{6}$ & \\
\hline c) GSPB Nr. 2401 & $1,1 \times 10^{7}$ & & & $8,8 \times 10^{6}$ \\
\hline Kontrolle GSPB 1955 & $2,1 \times 10^{7}$ & 0 & 0 & 0 \\
\hline
\end{tabular}

a) = Mutante mit Resistenz gegen 100 ppm Rifampicin

b) = Mutante mit Resistenz gegen 150 ppm Streptomycin

c) = Mutante mit Resistenz gegen 100 ppm Rifampicin und 150 ppm Streptomycin

Fast in allen Versuchsgliedern wurden auf den Nährböden ohne Antibiotika ähnlich viele Bakterienkolonien gezählt, wie auf den Antibiotika-haltigen Nährmedien. Allerdings zeigte die gegen 150 ppm Streptomycin und 100 ppm Rifampicin resistente Mutante auf dem Selektivmedium Kolonien mit unterschiedlicher Größe und mit uneinheitlichem Aussehen. 
Der untersuchte resistente Xcp-Stamm GSPB 2503 zeigte in den Pelargonienpflanzen im Vergleich zum Wildstamm keine unterschiedliche Virulenz. Die ersten Symptome traten 7 - 10 Tage nach der Inokulation auf. Die Symptome der Blattflecken erschienen zuerst als wasserdurchsogene, ölig durchscheinende Punkte auf der Blattunterseite. Später zeigten diese Flecken ein braunrotes Zentrum.

Am häufigsten traten Symptome am Stengel auf. Die Stengelfäule ging von der Basis wie auch von oberen Stengelteilen aus. Zuerst bildeten sich glasige, grünliche Stellen aus, die in trockene, braune bis schwarze Läsionen übergingen.

Nach diesen Ergebnissen wurde der gegen 100 ppm Rifampicin resistente Xcp-Stamm 2503 wegen seiner Stabilität und der Einheitlichkeit bei den gesamten Versuchen für die weiteren Versuche ausgewählt.

\subsection{Bestimmung der Inokulumskonzentrationen mit der Antibiotika-resistenten Xcp-Mutante}

Die Bakterien wurden wie in 2.7 beschrieben angezogen. Unmittelbar vor der Inokulation der Pflanzen wurden aus der hergestellten Inokulums-Suspension $10 \mu \mathrm{l}$ von jeder Konzentration auf dem Antibiotika-haltigen NGAR-Medium vierfach ausplattiert. Nach 2 - 3 d Inkubation bei $25^{\circ} \mathrm{C}$ wurden die Bakterienkolonien ausgezählt (Tab. 3).

Tab. 3: Ermittelte Bakterienkonzentration in der Inokulums-Suspension, die pro Pflanze eingesetzt wurde (cfu / $10 \mu \mathrm{l}$ ), in 4 Wiederholungen

\begin{tabular}{l|l|lrrr|c}
\hline $\begin{array}{l}\text { Bakterien- } \\
\text { konzentration }\end{array}$ & $\begin{array}{l}\text { Volumen der ausplattierten } \\
\text { Bakteriensuspension }\end{array}$ & \multicolumn{3}{|l|}{$\begin{array}{l}\text { Anzahl der auf NGAR ge- } \\
\text { bildeten Xcp-Kolonien }\end{array}$} & $\varnothing$ \\
\hline \hline $10^{3}$ & $10 \mu \mathrm{l}$ & 2 & 5 & 6 & 1 & 4 \\
$10^{4}$ & $10 \mu \mathrm{l}$ & 89 & 92 & 75 & 70 & 81 \\
$10^{5}$ & $10 \mu \mathrm{l}$ & 408 & 380 & 352 & 488 & 407 \\
\hline
\end{tabular}

Es stellte sich heraus, dass die ermittelten Konzentrationen bei allen Verdünnungsreihen deutlich niedriger waren als sie erfahrungsgemäß erwartet wurden. Dies könnte an dem relativ niedrigen verwendeten Volumen $(10 \mu \mathrm{l})$ gelegen haben, bei dem ein geringer Flüssigkeitsverlust das Ergebnis stark verfälschen kann. 


\subsection{Einfluss der Temperatur auf die Vermehrung und Latenz von $X c p$ in planta bei verschiedenen Inokulumskonzentrationen}

Symptome und Krankheitsverlauf: Die ersten Krankheitssymptome waren immer Welkeerscheinungen. Anfänglich welkten nur einzelne Blattbereiche, später wurde der gesamte Blattrand schlaff. Das Blatt ähnelte in seiner Form einem Regenschirm (siehe auch BRÖTHER, 1981b und KREBS, 1992). Wenn diese typischen Symptome auftraten (Abb. 3), wurden die Pflanzen als krank bezeichnet. Der Anteil dieser kranken Pflanzen wird für jedes Versuchsglied in den folgenden Tabellen und Abbildungen wiedergegeben.

Etwa 2 - 3 Wochen später, am frühesten bei den Jungpflanzen, entwickelten sich die länglichen, zunächst glasig aussehenden Stengelflecken, die sich schnell vergrößerten, erst dunkelgrün, dann schwärzlich wurden und schließlich in eine Trockenfäule übergingen (Abb. 4). Ausgehend von dem Inokulationspunkt wurde häufig ein einseitiger Befall festgestellt (Abb. 5). Gelegentlich traten an dem fast abgestorbenen Stengelstumpf noch Sprosse auf, die sich oft noch erstaunlich lange halten konnten, ehe sie einschrumpften und abstarben.

Außerdem traten an den Pflanzen Blattflecken auf (Abb. 6). Die Symptome der Blattflecken erschienen zuerst als kleine, rundliche, dunkelgrüne bis gelbgrüne wasserdurchsogene, ölig durchscheinende Punkte auf der Blattunterseite. Später können diese Flecken ein braunrotes Zentrum zeigen. In diesem Entwicklungsabschnitt werden sie auch auf der Blattoberseite erkennbar. Das erkrankte Gewebe färbt sich weiter dunkelbraun und nekrotisiert. Im durchfallenden Licht sind die dunklen Flecken von einem gelbgrünen Ring umgeben (sogenannte Vogelaugenflecke) und dadurch deutlich zu erkennen; diese Flecken können auch zusammenfließen (BRÖTHER, 1979). Abgestorbene Pflanzenteile oder Blätter fallen lange nicht ab, sondern können mehrere Monate an der Pflanze hängen bleiben. Eventuell neu gebildete Blätter bleiben klein und sind graugrün verfärbt.

Die Ergebnisse der mikrobiologischen Untersuchungen sind im Folgenden vollständig nur für die Bakterienzahlen in symptomlosen Stengeln, d. h. bei Latenz, wiedergegeben (Tab. 5, 7, 9, 11, 13 und 15). Im kranken Pflanzengewebe wurden immer sehr hohe Bakterienkonzentrationen gefunden $\left(10^{7}\right.$ bis $10^{9} \mathrm{cfu} / \mathrm{g}$ Frischgewicht), die exemplarisch in Abbildungen 10 und 14 wiedergegeben sind. 


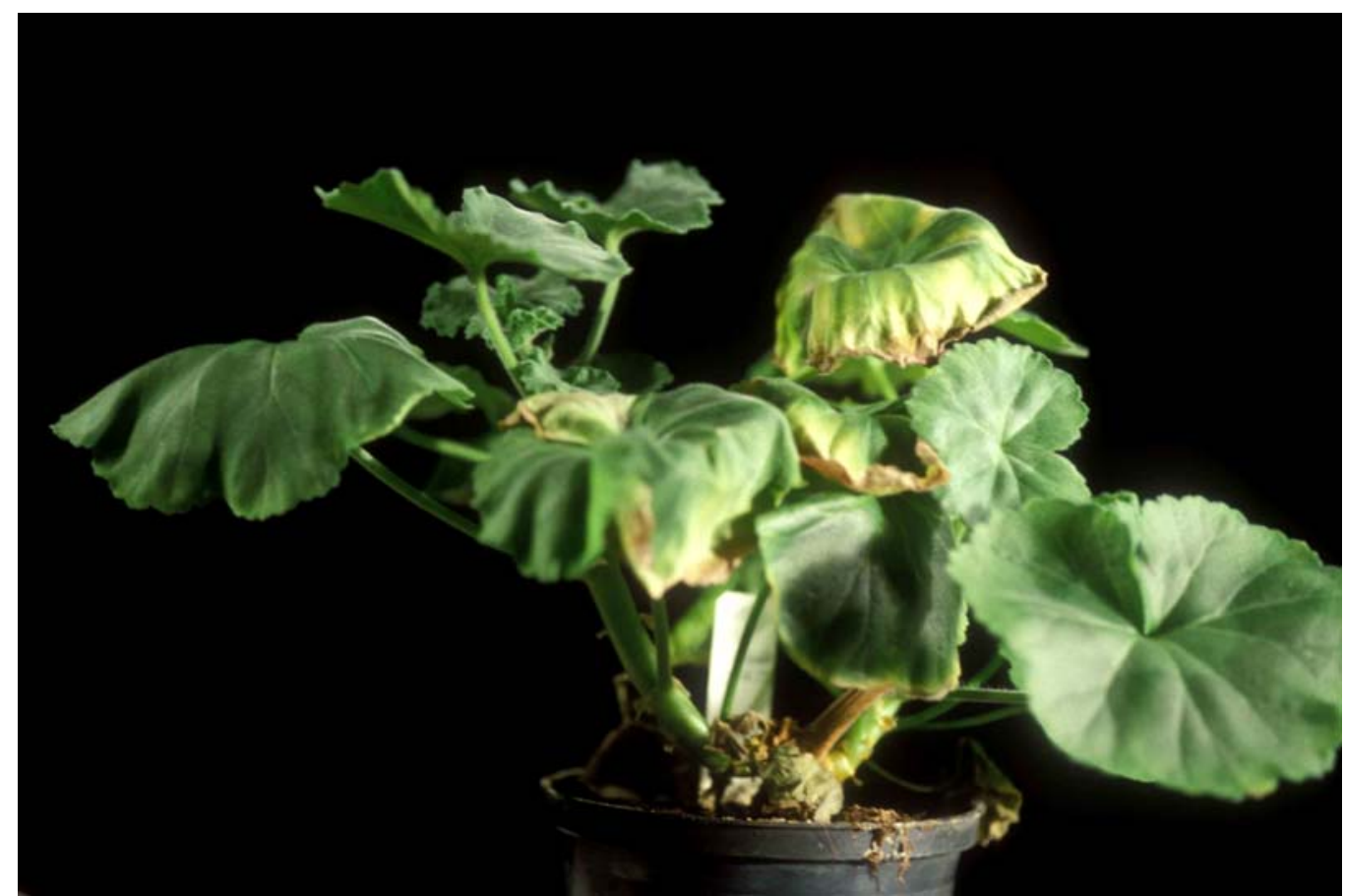

Abb. 3: Typische Anfangssymptome der "Regenschirm“-Welke

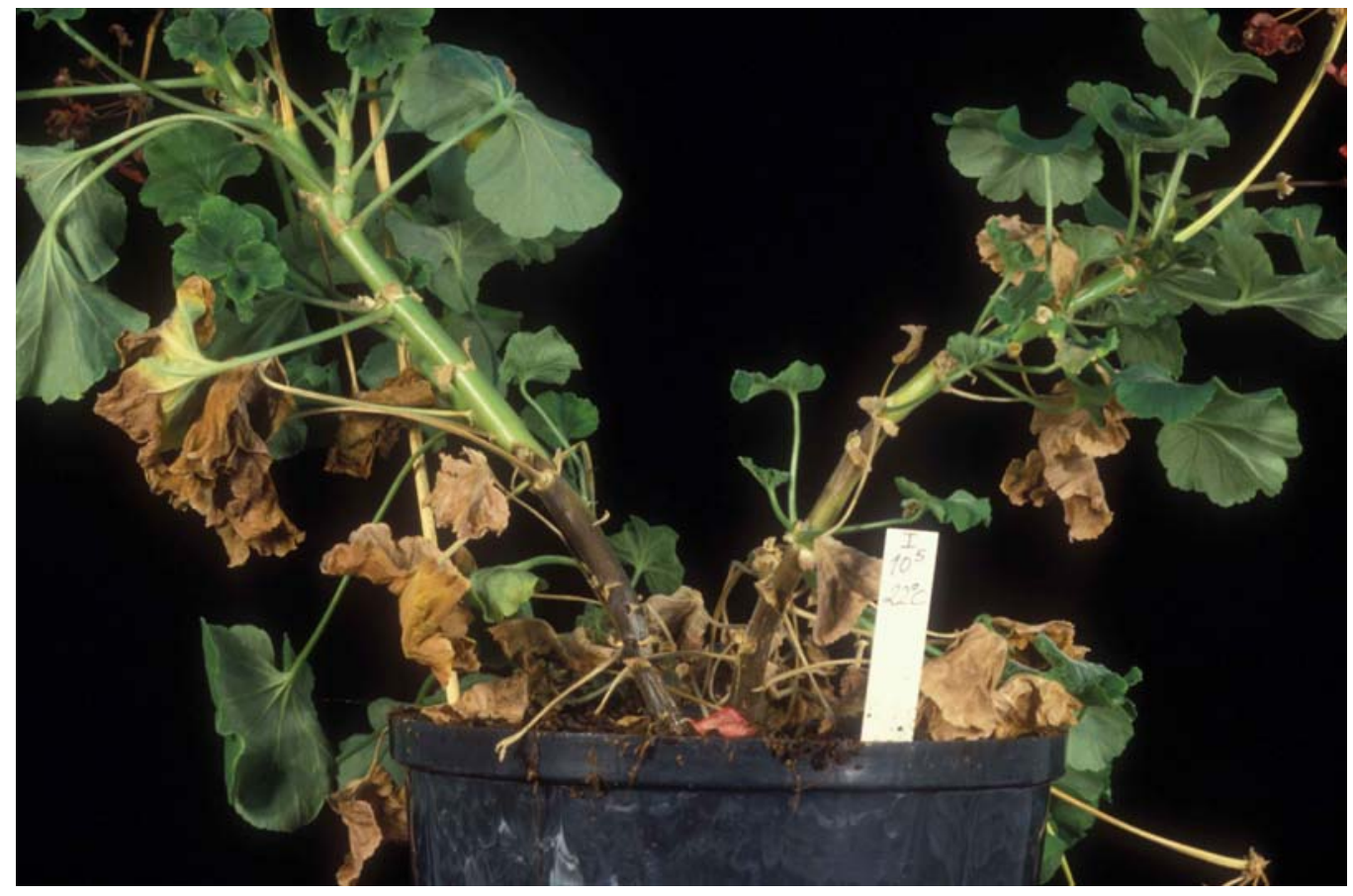

Abb. 4: Dunkelbraune Stengelflecken, die in Trockenfäule übergehen 


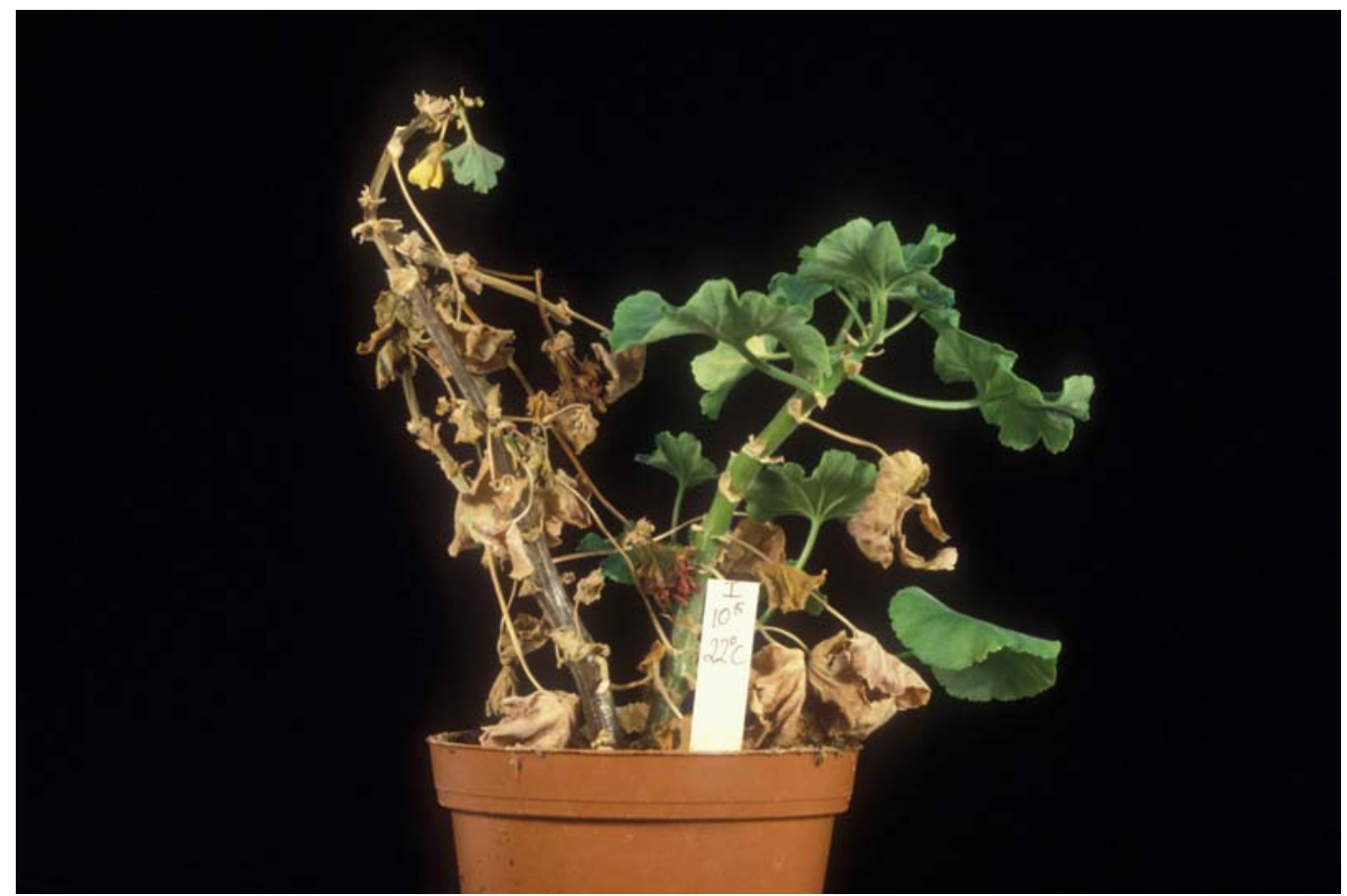

Abb. 5: Fortgeschrittener einseitiger Befall mit Trockenfäule, die verdorrten Blätter fallen nicht $a b$

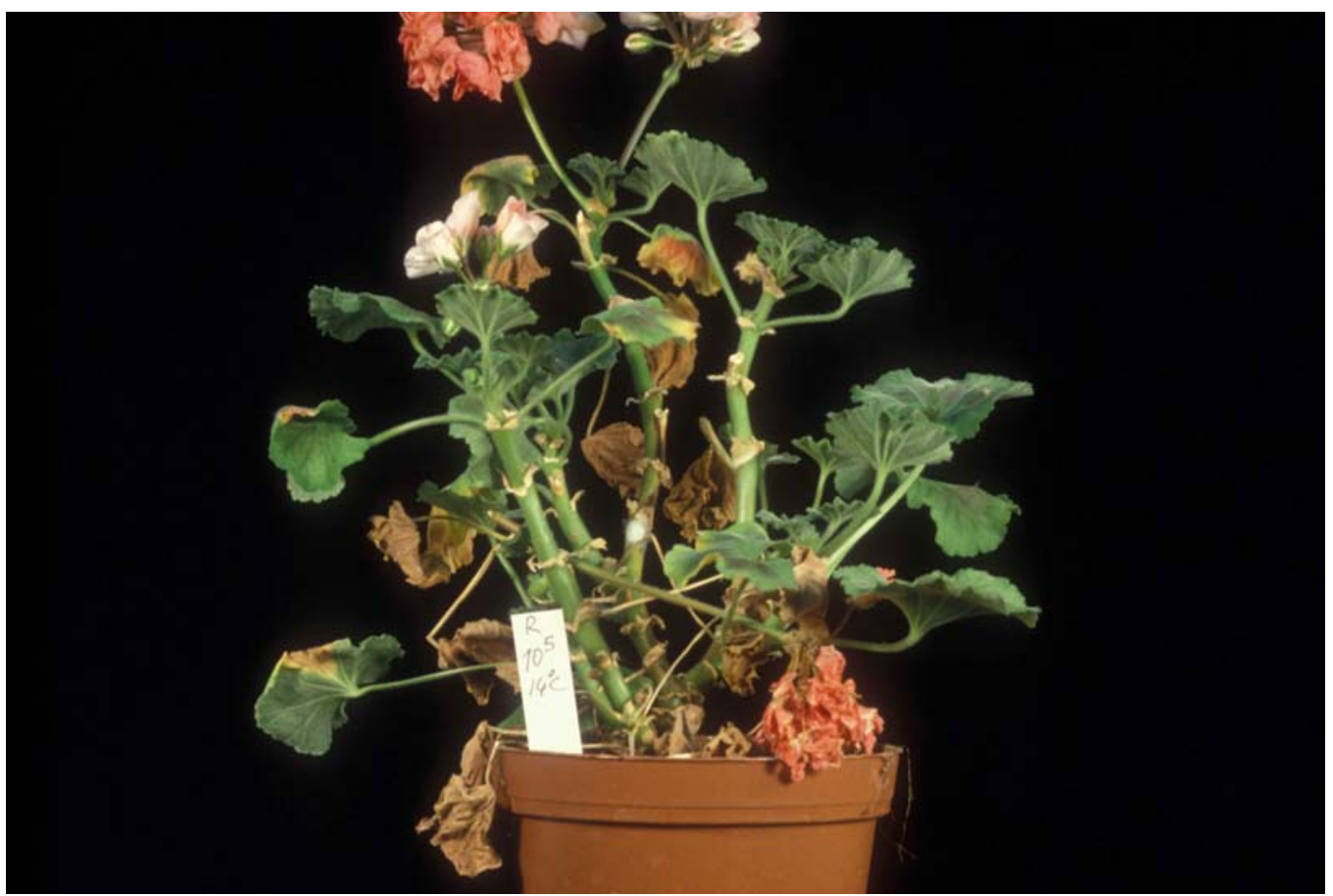

Abb. 6: Typische Blattflecken, z. T. V-förmig oder eine Blatthälfte ist rötlich, einige Blätter ganz verdorrt, die noch grünen Blätter sind schlaff 


\subsection{1 $25^{\circ} \mathrm{C}$ und $10^{5} \mathrm{cfu} / \mathrm{ml}$}

Zwei Wochen nach der Inokulation (23. 01. 1996): Die Pflanzen zeigten an der Inokulationsstelle leichte Welke. Von jeder untersuchten Pflanze wurden 5 Proben entnommen (eine Probe aus dem Inokulationspunkt, je zwei Proben mit $2 \mathrm{~cm}$ Abstand unter und über dem Inokulationpunkt). Xcp konnte in den Pflanzen beider Sorten nachgewiesen werden (Tab. 5).

Einen Monat nach der Inokulation erfolgte eine relative starke systemische Ausbreitung von $X c p$. Zu diesem Zeitpunkt verwelkten die Blätter nicht nur am inokulierten Stengel sondern auch an benachbarten, nicht inokulierten Stengeln. Die Vermehrung und Ausbreitung von $X c p$ verlief in "Rosario“ schneller als in "Isabell“ und führte zu stärkerer Welke. Dies wurde durch die Bakterienkonzentrationen an der Inokulationsstelle bei "Rosario“ $\left(8,2 \times 10^{9}\right)$ und bei "Isabell“ (nur 3,1 x 107 cfu/g Frischgewicht) bestätigt. Auch der Anteil der erkrankten Pflanzen war bei "Rosario“ (35\%) deutlich höher als bei "Isabell (18\%) (Tab. 4). In den untersuchten Proben wurden die Bakterien bis zu den Wurzeln gefunden. Um genau nachweisen zu können, wie weit die Bakterien sich in der Pflanze systemisch ausbreiteten, wurde wie zu Abb. 10 beschrieben verfahren.

Die Untersuchungen ergaben somit, dass sich die Bakterien in der Pflanze sowohl akropetal als auch basipetal ausbreiteten. Eine Bevorzugung der einen oder anderen Richtung konnte nicht festgestellt werden.

Ein halbes Jahr nach der Inokulation (03. 07. 1996) waren 70\% der Pflanzen von "Isabell" und 83\% von "Rosario“ krank (Tab. 4). Nun wurden die restlichen noch gesund aussehenden Pflanzen aufgeteilt. Die eine Hälfte wurde bei $25^{\circ} \mathrm{C}$ weiter kultiviert und die andere bei $15{ }^{\circ} \mathrm{C}$ aufgestellt, um zu überprüfen, ob durch die Temperaturumstellung die Ausbreitung von $X c p$ in der Pflanze beeinflusst wurde.

Erste weitere Symptome wurden im September 1997 an Isabell bei $25{ }^{\circ} \mathrm{C}$ festgestellt. Zum Nachweis der Bakterien wurden Proben diesmal nicht nur an den Pflanzenteilen mit Welke entnommen, sondern auch von gesund aussehenden Nachbarstengeln. Diese Isolationen aus symptomlosen Pflanzen (Latenz) ergaben bei Isabell Bakterienkonzentrationen von 8,2 x $10^{3} \mathrm{cfu} / \mathrm{g}$ Frischgewicht. Bei Rosario wurden die markierten Bakterien nur an der Inokulationsstelle (5,6 x $10^{3} \mathrm{cfu} / \mathrm{g}$ Frischgewicht) gefunden.

Am 12. 11. 1997 wurden zur mikrobiologischen Untersuchung der völlig gesund aussehenden Pflanzen die Proben nicht in $2 \mathrm{~cm}$ sondern in $4 \mathrm{~cm}$ Abständen, vom Inokulations- 
punkt ausgehend, entnommen. Die markierten Bakterien wurden nur an der Inokulationsstelle (3,4 x 10 $0^{4}$ und 9,1 x $10^{3} \mathrm{cfu} / \mathrm{g}$ Frischgewicht) gefunden (Tab. 5).

Im dritten Jahr (1998) wurden keine Symptome beobachtet, und ab August 1998 wurden die Pflanzen wöchentlich mit 1\% Hakaphos gedüngt. Durch die Nährstoffzugabe kam es zu einer Wachstumsstimulation, die wahrscheinlich die Latenzphase des Befalls bei der 15 ${ }^{\circ} \mathrm{C}$ Variante unterbrach und zur Befallszunahme mit sichtbaren Symptomen sehr spät führte (Isabell auf 88\%, Rosario auf 97\%). Die Pflanzen zeigten am Anfang einseitigen Befall, im Laufe der Zeit wurden die Pflanzen total befallen.

Tab. 4 und Abb. 7: Einfluss der Kultivierungstemperatur auf die Reaktion von Pelargonienpflanzen der Sorten "Rosario“ und "Isabell“ nach Stengelinokulation mit $\mathbf{1 0}^{\mathbf{5}} \mathbf{c f u} / \mathbf{m l}$. Die Zahlen geben die erkrankten Pflanzen in Prozent aller inokulierten Pflanzen an. Die Pflanzen wurden am 08. 01. 1996 inokuliert.

\begin{tabular}{|r|c|c|c|c|}
\hline Datum der Pro- \\
benahme
\end{tabular}




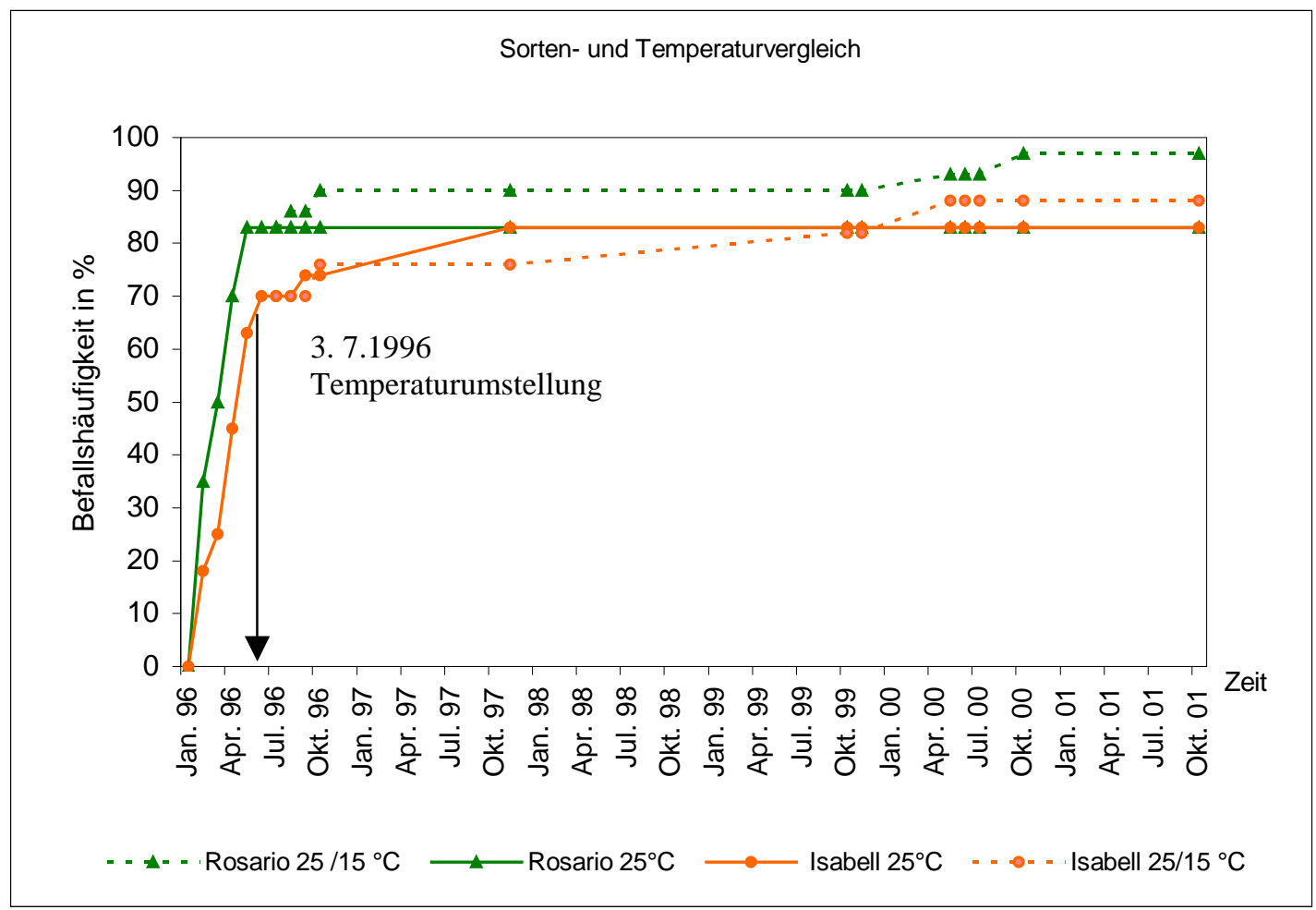

Tab. 5: Mikrobiologischer Nachweis von $X c p$ (in cfu/g Stengel) in latent befallenen Pelargonienpflanzen nach Stengelinokulation mit $\mathbf{1 0}^{\mathbf{5}} \mathbf{~ c f u} / \mathbf{m l}$ und Aufstellung bei $25^{\circ} \mathrm{C}$ oder $25 / 15^{\circ} \mathrm{C}$

\begin{tabular}{|c|c|c|c|c|c|c|}
\hline \multicolumn{7}{|c|}{$25^{\circ} \mathrm{C}$} \\
\hline \multicolumn{4}{|c|}{ Isabell } & \multicolumn{3}{|c|}{ Rosario } \\
\hline Probenahme & $\mathbf{a}$ & b & c & $\mathbf{a}$ & b & c \\
\hline 23. 01.1996 & $3,5 \times 10^{5}$ & $5,6 \times 10^{3}$ & $1,5 \times 10^{4}$ & $3,8 \times 10^{3}$ & ng & ng \\
\hline 10.09. 1996 & $2,3 \times 10^{5}$ & ng & ng & $5,6 \times 10^{3}$ & & \\
\hline 3. 11. 1996 & $2,9 \times 10^{5}$ & ng & ng & $7 \times 10^{6}$ & ng & ng \\
\hline 10.12. 1996 & & & & $1,9 \times 10^{3}$ & ng & $4 \times 10^{2}$ \\
\hline 12. 11. 1997 & $\begin{array}{l}3,4 \times 10^{4} \\
9,1 \times 10^{3}\end{array}$ & $\begin{array}{l}\text { ng } \\
\text { ng }\end{array}$ & $\begin{array}{l}\text { ng } \\
\text { ng }\end{array}$ & $1,6 \times 10^{3}$ & ng & ng \\
\hline \multicolumn{7}{|c|}{$25^{\circ} \mathrm{C} / 15^{\circ} \mathrm{C}$} \\
\hline 14. 08. 1996 & $2,4 \times 10^{4}$ & ng & ng & $4,1 \times 10^{4}$ & ng & ng \\
\hline
\end{tabular}

a: Inokulationsstelle

b: $2-5 \mathrm{~cm}$ über Inokulationsstelle

c: $2-5 \mathrm{~cm}$ unter Inokulationsstelle

ng: untersucht, aber nicht gefunden 


\subsection{2 $25^{\circ} \mathrm{C}$ und $10^{4} \mathrm{cfu} / \mathrm{ml}$}

Zwei Wochen nach der Inokulation wurden die ersten Pflanzen beider Sorten mikrobiologisch untersucht. Bei "Isabell“ wurden an der Inokulationsstelle (Tab. 7) und am Nachbarstengel Bakterien gefunden, obwohl die Pflanzen von außen gesund aussahen. Dagegen waren die Pflanzen von “Rosario“ z. T. stark befallen, und die Ausbreitung von Xcp erfolgte akropetal und basipetal.

Einen Monat nach der Inokulation wurden bei "Rosario“ an der Inokulationsstelle 4,4 x $10^{8}$ cfu/g Frischgewicht Bakterien gefunden, und 13\% der Pflanzen waren krank (Tab. 6). Zum gleichen Termin wurden bei Isabell 5,3 x $10^{8} \mathrm{cfu} / \mathrm{g}$ Frischgewicht markierte Bakterien gefunden, und nur 3\% der Pflanzen waren krank. Die befallenen Pflanzen wurden ebenfalls, wie in Abb. 10 beschrieben, auf Bakteriengehalt untersucht. Es wurde auch hier festgestellt, dass bei "Rosario“ die Ausbreitung von $X c p$ viel schneller als bei "Isabell“ erfolgte. Bis zum 03. 07. 1996 waren 15\% von Isabell und 33\% von Rosario befallen (Tab. 6). Nach der Temperaturumstellung am 03. 07. 1996 lief die Krankheitsentwicklung an den bis dahin noch gesund aussehenden Pflanzen weiter, wenn auch in unterschiedlicher Stärke. Bis zum 11. 11. 1999, d. h. mehr als 3 Jahre nach Inokulation, wurden an beiden Sorten mehr Pflanzen bei der höheren Kulturtemperatur $\left(25^{\circ} \mathrm{C}\right)$ als bei $15^{\circ} \mathrm{C}$ krank (Tab. 6 und Abb. 8). Danach erkrankten weitere Pflanzen nur noch bei der niedrigeren Temperatur (15 ${ }^{\circ} \mathrm{C}$ ) aber nicht mehr bei $25^{\circ} \mathrm{C}$, so dass am Ende des Versuches mehr Pflanzen bei $15{ }^{\circ} \mathrm{C}$ erkrankt waren (Isabell: 74\%, Rosario: 100\%) als bei $25{ }^{\circ} \mathrm{C}$ (Isabell 60\%, Rosario 73\%). 
Tab. 6 und Abb. 8: Einfluss der Kultivierungstemperatur auf die Reaktion von Pelargonienpflanzen der Sorten "Rosario" und "Isabell“" nach Stengelinokulation mit $\mathbf{1 0}^{\mathbf{4}} \mathbf{c f u} / \mathbf{m l}$. Die Zahlen geben die erkrankten Pflanzen in Prozent aller inokulierten Pflanzen an. Die Pflanzen wurden am 08. 01. 1996 inokuliert.

\begin{tabular}{|c|c|c|c|c|}
\hline $\begin{array}{l}\text { Datum der Pro- } \\
\text { bennahme }\end{array}$ & Isabell $25^{\circ} \mathrm{C}$ & \begin{tabular}{|c|} 
Isabell \\
Umstellung von \\
$25^{\circ} \mathrm{C}$ auf $15^{\circ} \mathrm{C}$
\end{tabular} & Rosario $25^{\circ} \mathrm{C}$ & $\begin{array}{c}\text { Rosario } \\
\text { Umstellung von } \\
25^{\circ} \mathrm{C} \text { auf } 15^{\circ} \mathrm{C}\end{array}$ \\
\hline 08.01 .96 & 0 & & 0 & \\
\hline 02.02 .96 & 3 & & 13 & \\
\hline 03.03 .96 & 3 & & 23 & \\
\hline 05.04 .96 & 5 & & 28 & \\
\hline 13.05 .96 & 8 & & 33 & \\
\hline 03.07 .96 & 15 & 15 & 33 & 33 \\
\hline 14.08 .96 & 15 & 20 & 33 & 33 \\
\hline 10.09 .96 & 28 & 26 & 41 & 38 \\
\hline 07.10 .96 & 41 & 43 & 50 & 38 \\
\hline 07.11 .96 & 41 & 43 & 54 & 38 \\
\hline 01.12 .96 & 46 & 43 & 68 & 38 \\
\hline 12.11 .97 & 60 & 43 & 73 & 38 \\
\hline 17.12 .97 & 60 & 43 & 73 & 38 \\
\hline 14.10 .99 & 60 & 54 & 73 & 38 \\
\hline 11.11 .99 & 60 & 54 & 73 & 49 \\
\hline 22.05 .00 & 60 & 72 & 73 & 60 \\
\hline 22.06 .00 & 60 & 72 & 73 & 89 \\
\hline 21.07 .00 & 60 & 72 & 73 & 100 \\
\hline 21.07 .01 & 60 & 74 & 73 & 100 \\
\hline
\end{tabular}




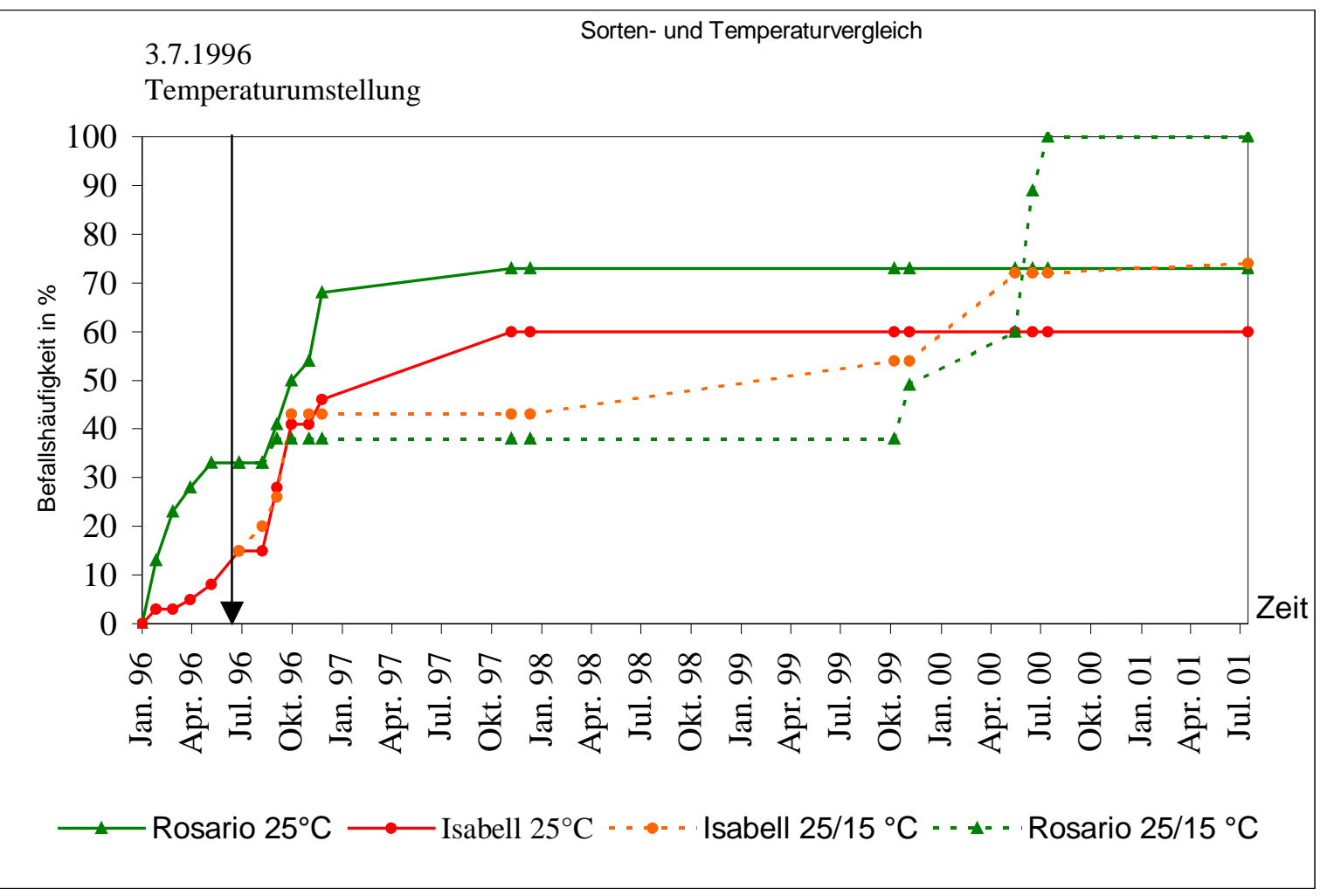

Tab. 7: Mikrobiologischer Nachweis von Xcp (in cfu/g Stengel) in latent befallenen Pelargonienpflanzen nach Stengelinokulation mit $\mathbf{1 0}^{4} \mathbf{c f u} / \mathbf{m l}$ und Aufstellung bei $25^{\circ} \mathrm{C}$ oder $25 / 15^{\circ} \mathrm{C}$

\begin{tabular}{|c|c|c|c|c|c|c|}
\hline \multicolumn{7}{|c|}{$25^{\circ} \mathrm{C}$} \\
\hline \multicolumn{4}{|c|}{ Isabell } & \multicolumn{3}{|c|}{ Rosario } \\
\hline Probenahme & $\mathbf{a}$ & $\mathbf{b}$ & C & $\mathbf{a}$ & b & C \\
\hline 23. 01.1996 & $2,5 \times 10^{2}$ & ng & ng & & & \\
\hline 04. 03. 1996 & $\begin{array}{l}3 \times 10^{2} \\
1,4 \times 10^{3}\end{array}$ & $\begin{array}{l}\text { ng } \\
\text { ng }\end{array}$ & $\begin{array}{l}\text { ng } \\
\text { ng }\end{array}$ & & & \\
\hline 05. 04. 1996 & & & & $8,1 \times 10^{3}$ & $3,8 \times 10^{3}$ & ng \\
\hline 13. 05.1996 & & & & $3,8 \times 10^{3}$ & ng & ng \\
\hline 3. 07. 1996 & $4,4 \times 10^{4}$ & $1,3 \times 10^{3}$ & $9,5 \times 10^{2}$ & $3 \times 10^{3}$ & ng & ng \\
\hline 10. 09. 1996 & $\begin{array}{l}3,4 \times 10^{3} \\
1,1 \times 10^{2}\end{array}$ & $\begin{array}{l}\text { ng } \\
\text { ng }\end{array}$ & $\begin{array}{l}\text { ng } \\
\text { ng }\end{array}$ & $\begin{array}{l}6,3 \times 10^{3} \\
1,2 \times 10^{2}\end{array}$ & $\begin{array}{l}\text { ng } \\
\text { ng }\end{array}$ & $\begin{array}{l}\text { ng } \\
\text { ng }\end{array}$ \\
\hline 05. 12. 1996 & $3,4 \times 10^{2}$ & ng & ng & $6,3 \times 10^{3}$ & ng & ng \\
\hline
\end{tabular}




\begin{tabular}{|c|c|c|c|c|c|c|}
\hline \multicolumn{7}{|c|}{$25^{\circ} \mathrm{C}$} \\
\hline & \multicolumn{3}{|c|}{ Isabell } & \multicolumn{3}{|c|}{ Rosario } \\
\hline & $2,2 \times 10^{2}$ & ng & ng & $1,2 \times 10^{2}$ & ng & ng \\
\hline 11.11. 1997 & $\begin{array}{l}3,7 \times 10^{3} \\
1 \times 10^{4}\end{array}$ & $\begin{array}{l}\text { ng } \\
\text { ng }\end{array}$ & $\begin{array}{l}3,7 \times 10^{3} \\
\text { ng }\end{array}$ & $\begin{array}{l}4,5 \times 10^{4} \\
3 \times 10^{2}\end{array}$ & $\begin{array}{l}\text { ng } \\
\text { ng }\end{array}$ & $\begin{array}{l}3,7 \times 10^{3} \\
\text { ng }\end{array}$ \\
\hline 09. 12. 1997 & & & & $\begin{array}{l}1,3 \times 10^{4} \\
1 \times 10^{2}\end{array}$ & $\begin{array}{l}\text { ng } \\
\text { ng }\end{array}$ & $\begin{array}{l}\text { ng } \\
\text { ng }\end{array}$ \\
\hline \multicolumn{7}{|c|}{$25^{\circ} \mathrm{C} / 15^{\circ} \mathrm{C}$} \\
\hline 03. 03. 1996 & & & & $3,3 \times 10^{3}$ & ng & ng \\
\hline 07. 10. 1996 & & & & $3 \times 10^{5}$ & ng & ng \\
\hline 07. 10. 1996 & & & & $1,8 \times 10^{5}$ & & \\
\hline 12. 11. 1997 & $\begin{array}{l}3 \times 10^{4} \\
9 \times 10^{2}\end{array}$ & $\begin{array}{l}\text { ng } \\
\text { ng }\end{array}$ & $\begin{array}{l}\text { ng } \\
\text { ng }\end{array}$ & $1,3 \times 10^{3}$ & ng & ng \\
\hline
\end{tabular}

ng: untersucht, aber nicht gefunden

\subsection{3 $25^{\circ} \mathrm{C}$ und $10^{3} \mathrm{cfu} / \mathrm{ml}$}

Zwei Wochen nach der Inokulation wurden bei "Isabell“ 4,4 x $10^{2} \mathrm{cfu} / \mathrm{g}$ Frischgewicht und bei "Rosario“ 8,8 x $10^{2}$ cfu/g Frischgewicht an der Inokulationsstelle festgestellt (Tab. 9), aber nicht im benachbarten Gewebe. Bei “Rosario“ traten die ersten Symptome einen Monat nach der Inokulation und bei "Isabell“ erst vier Monate nach der Inokulation auf (Tab. 8). Die Pflanzen, die konstant bei $25{ }^{\circ} \mathrm{C}$ gehalten wurden, waren am $01.12 .1996 \mathrm{zu} 42 \%$ (Isabell) bzw. 65\% (Rosario) krank, während bei $15{ }^{\circ} \mathrm{C}$ nur 5\% bzw. 13\% erkrankten. Im Jahr 1997 wurden mehrere gesunde Pflanzen von "Isabell“" und "Rosario" untersucht, und nur einmal bei "Rosario“ am 12. 11. 1997 sehr wenige Bakterien ( 1 x $10^{2}$ cfu/ml) gefunden (Tab. 9).

Bei den Pflanzen, die am 03. 07. 1996 zur kühleren Temperatur transferiert wurden, ging ab Ende 1999 bei beiden Sorten die Latenz in akute Krankheit über. Danach erkrankten alle Isabell-Pflanzen Mitte Februar 2000 und alle Pflanzen von Rosario Anfang Oktober 2000 (Tab. 8). Am Anfang war ein einseitiger Befall zu erkennen, später waren die gesamten Pflanzen stark befallen. Auch in dieser Versuchsvariante kam sehr deutlich heraus, dass 
bei den Pflanzen, die ein halbes Jahr nach der Inokulation zur niedrigeren Temperatur (15 ${ }^{\circ} \mathrm{C}$ ) transferiert worden waren, die Ausbreitung der Bakterien in der Pflanze viel langsamer aber kontinuierlich erfolgte. Offenbar verlangsamte die niedrige Temperatur die Krankheitsentwicklung, jedoch blieben die Bakterien in der Latenzphase am Leben und konnten nach längerer Zeit die gesamten Pflanzen besiedeln und dadurch stark schädigen.

Tab. 8 und Abb. 9: Einfluss der Kultivierungstemperatur auf die Reaktion von Pelargonienpflanzen der Sorten "Rosario“ und "Isabell“" nach Stengelinokulation mit $\mathbf{1 0}^{3} \mathbf{c f u} / \mathbf{m l}$. Die Zahlen geben die erkrankten Pflanzen in Prozent aller inokulierten Pflanzen an. Die Pflanzen wurden am 08. 01. 1996 inokuliert.

\begin{tabular}{|c|c|c|c|c|}
\hline $\begin{array}{l}\text { Datum der Pro- } \\
\text { benahme }\end{array}$ & Isabell $25^{\circ} \mathrm{C}$ & $\begin{array}{l}\text { Isabell Um- } \\
\text { stellung von } 25 \\
{ }^{\circ} \mathrm{C} \text { auf } 15^{\circ} \mathrm{C}\end{array}$ & Rosario $25^{\circ} \mathrm{C}$ & $\begin{array}{l}\text { Rosario Um- } \\
\text { stellung von } 25 \\
{ }^{\circ} \mathrm{C} \text { auf } 15^{\circ} \mathrm{C}\end{array}$ \\
\hline 08.01 .96 & 0 & & 0 & \\
\hline 02.02 .96 & 0 & & 3 & \\
\hline 03.03 .96 & 0 & & 3 & \\
\hline 05.04 .96 & 0 & & 3 & \\
\hline 13.05 .96 & 5 & & 13 & \\
\hline 03.07.96 & 5 & 5 & 13 & 13 \\
\hline 14.08 .96 & 14 & 5 & 13 & 13 \\
\hline 10.09 .96 & 14 & 5 & 13 & 13 \\
\hline 07.10 .96 & 18 & 5 & 32 & 13 \\
\hline 07.11 .96 & 32 & 5 & 51 & 13 \\
\hline 01.12 .96 & 42 & 5 & 65 & 13 \\
\hline 12.11 .97 & 42 & 5 & 65 & 13 \\
\hline 17.12 .97 & 42 & 5 & 65 & 13 \\
\hline 14.10 .99 & 42 & 5 & 65 & 13 \\
\hline 11.11 .99 & 42 & 55 & 65 & 13 \\
\hline 16.02 .00 & 42 & 100 & 65 & 27 \\
\hline 22.05 .00 & 42 & 100 & 65 & 56 \\
\hline 22.06 .00 & 42 & 100 & 65 & 83 \\
\hline 21.07 .00 & 42 & 100 & 65 & 83 \\
\hline 07.10 .00 & 42 & 100 & 65 & 100 \\
\hline 21.07 .01 & 42 & 100 & 65 & 100 \\
\hline
\end{tabular}




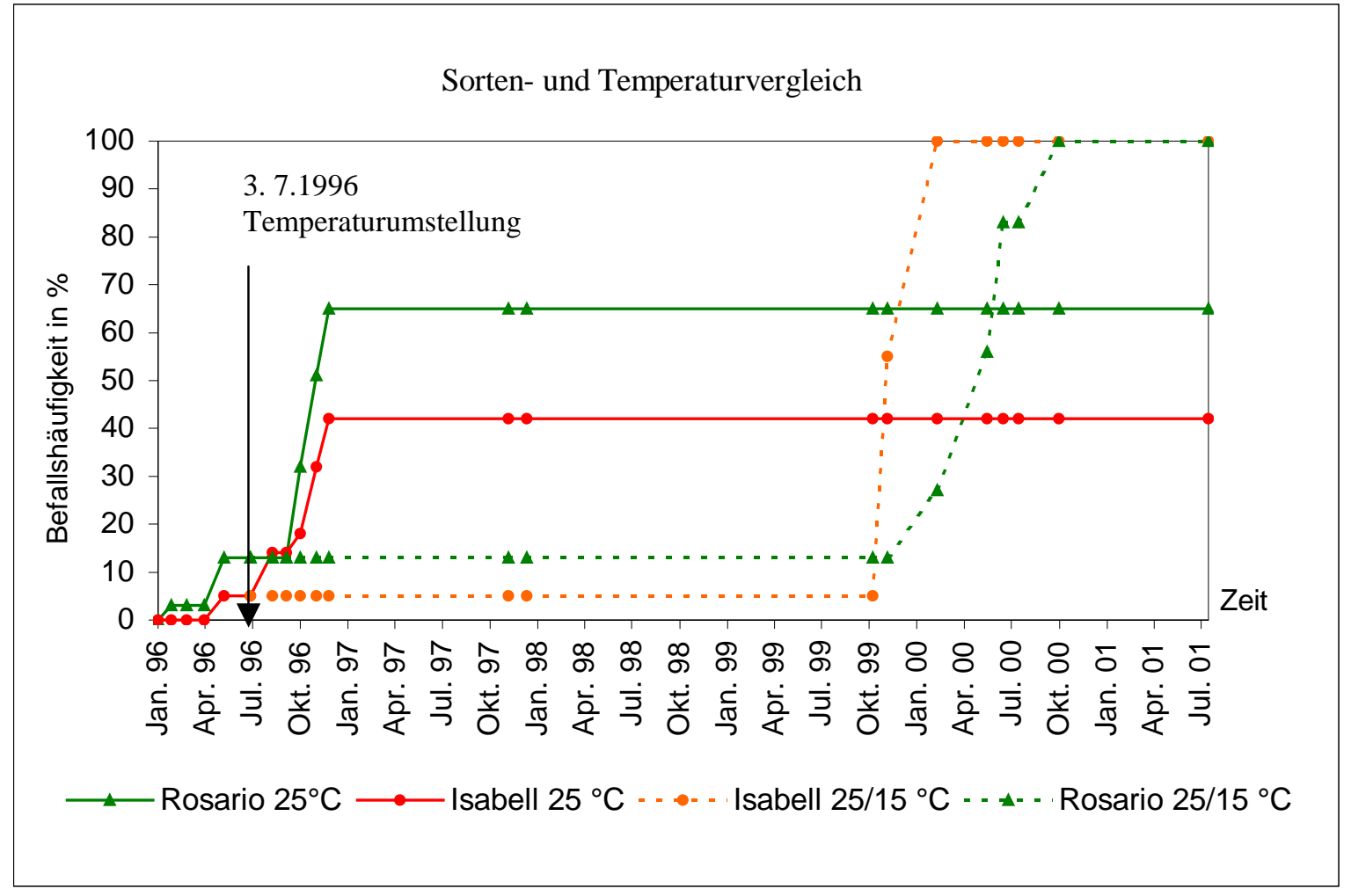

In Abb. 10 wird die Ausbreitung von Xcp innerhalb einer Pflanze von „Rosario“ dargestellt.

Die Inokulation erfolgte an der Stelle „Mitte 1“ mit ca. 100 Bakterien. Nach drei Monaten Kultivierung bei $25{ }^{\circ} \mathrm{C}$ wurden Isolationen aus verschiedenen Stellen der Pflanze rechts (R) und links (L) des Inokulationspunktes, Dolden und Blütenknospen, sowie aus den Wurzeln durchgeführt. Außerdem wurden die Bakterien im Boden und im Sickerwasser (siehe Kap. 2.9.5) gesucht. Fast in allen Proben wurden die markierten Bakterien nachgewiesen. Die recht hohen Konzentrationen der Bakterien in den Wurzeln (bis zu $10^{8}$ cfu/ml) erklären, dass auch in der Erde und im Sickerwasser die markierten Bakterien vorkamen. 
Abb. 10: Ausbreitung von $X_{c p}$ in einer Pelargonienpflanze der Sorte „Rosario“ und im

Sickerwasser 3 Monate nach Inokulation mit ca. 100 Bakterienzellen an der mit M1 bezeichneten Stelle, Inkubation bei $25{ }^{\circ} \mathrm{C}$ und $70 \%$ relativer Luftfeuchtigkeit.

\section{Pflanzenprobe}

Rechts 1

R 2

$\mathrm{R} \quad 3$

$\mathrm{R} \quad 4$

$\mathrm{R} \quad 5$

R 6

Rechts Dolde

Mitte 1

Mitte 2

Mitte * 3

Blütenknospen

Links 1

Links 2

L. Blatt u. Stiel

Wurzel1

Wurzel2

Wurzel 3

Erde 1

Erde 2

Sickerwasser

*: Inokulationsstelle

\section{Dichte cfu/g}

$8,2 \times 10^{7}$

$1,5 \times 10^{9}$

$1,7 \times 10^{9}$

$5,8 \times 10^{9}$

$2,3 \times 10^{9}$

$6,8 \times 10^{8}$

$>10^{8}$

$7,2 \times 10^{7}$

$1,1 \times 10^{9}$

$8,6 \times 10^{8}$

$>10^{8}$

$5,2 \times 10^{6}$

$>10^{8}$

n.gefunden

$1,3 \times 10^{8}$

$5,4 \times 10^{7}$

$1,4 \times 10^{8}$

$2,3 \times 10^{3}$

$5 \times 10^{3}$

$2 \times 10^{3}$

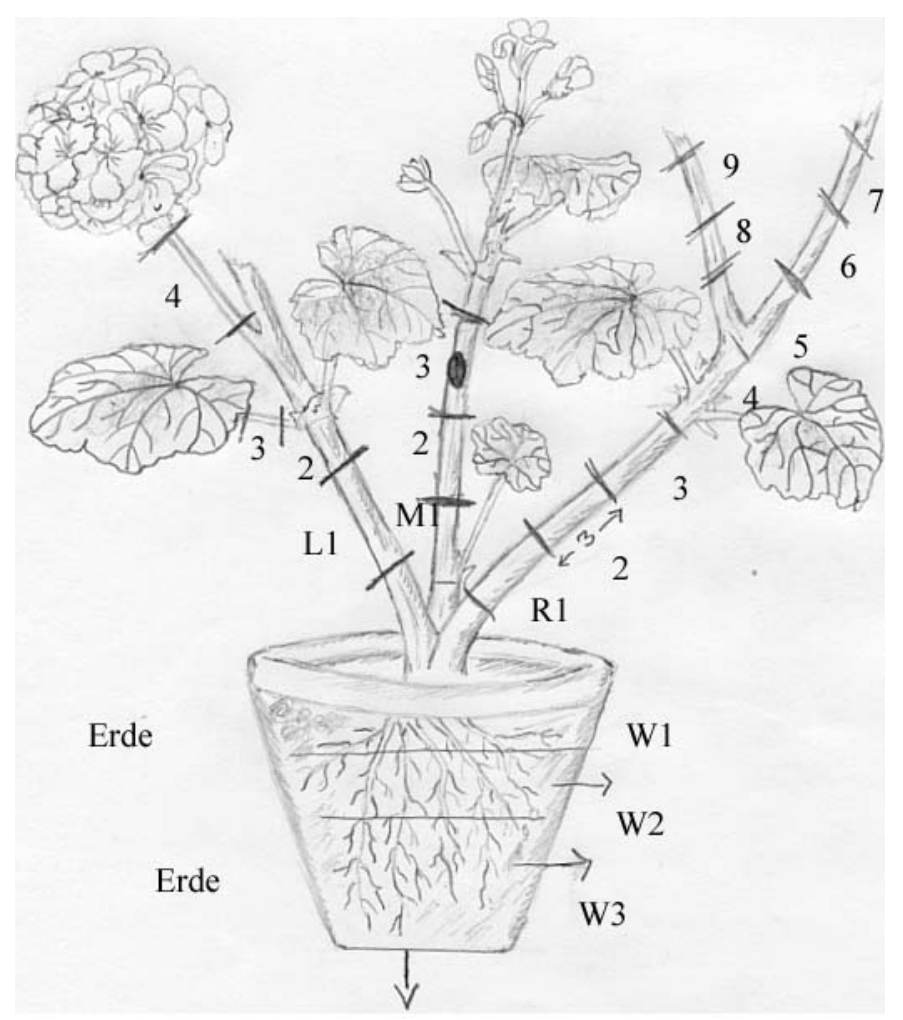


Tab. 9: Mikrobiologischer Nachweis von $X c p$ (in cfu/g Stengel) in latent befallenen Pelargonienpflanzen nach Stengelinokulation mit $\mathbf{1 0}^{3} \mathbf{c f u} / \mathbf{m l}$ und Aufstellung bei $25^{\circ} \mathrm{C}$ oder $25 / 15^{\circ} \mathrm{C}$

\begin{tabular}{|c|c|c|c|c|c|c|}
\hline \multicolumn{7}{|c|}{$25^{\circ} \mathrm{C}$} \\
\hline \multicolumn{4}{|c|}{ Isabell } & \multicolumn{3}{|c|}{ Rosario } \\
\hline Probenahme & $\mathbf{a}$ & b & C & $\mathbf{a}$ & b & C \\
\hline 23. 01.1996 & $4,4 \times 10^{2}$ & ng & ng & $8,8 \times 10^{2}$ & ng & ng \\
\hline 03. 03. 1996 & $\begin{array}{l}2 \times 10^{2} \\
2,2 \times 10^{3}\end{array}$ & $\begin{array}{l}\text { ng } \\
\text { ng }\end{array}$ & $\begin{array}{l}\text { ng } \\
\text { ng }\end{array}$ & & & \\
\hline 11.10. 1996 & $\begin{array}{l}1,1 \times 10^{3} \\
1,6 \times 10^{2}\end{array}$ & $\begin{array}{l}\text { ng } \\
\text { ng }\end{array}$ & $\begin{array}{l}\text { ng } \\
\text { ng }\end{array}$ & $2,7 \times 10^{3}$ & ng & ng \\
\hline 12. 111997 & & & & $1 \times 10^{2}$ & ng & ng \\
\hline \multicolumn{7}{|c|}{$25 / 15^{\circ} \mathrm{C}$} \\
\hline 07.10 .1996 & $1,2 \times 10^{2}$ & ng & ng & $5,2 \times 10^{2}$ & ng & ng \\
\hline 07.11.1996 & & & & $2,5 \times 10^{2}$ & ng & ng \\
\hline 16. 02. 1996 & & & & $4,2 \times 10^{4}$ & ng & ng \\
\hline
\end{tabular}

\subsection{4 $15{ }^{\circ} \mathrm{C}$ und $10^{5} \mathrm{cfu} / \mathrm{ml}$}

Die ersten Krankheitssymptome traten nach 2 Monaten bei wenigen Pflanzen auf (Tab. 10). Nach drei Wochen wurden die ersten Proben mikrobiologisch untersucht und nur in "Rosario" in gesund aussehenden Stengelteilen Bakterien gefunden (Tab. 11). Bei "Isabell“ wurden zum ersten Mal nach 5 Wochen Bakterien im symptomlosen Stengel gefunden, sowohl an der Inokulationsstelle $\left(1,2 \times 10^{6} \mathrm{cfu} / \mathrm{g}\right.$ Stengel-Frischgewicht) als auch über der Inokulationsstelle (2,8 x $10^{2}$ cfu/g Stengel-Frischgewicht). Die Bakterien breiteten sich bei "Rosario" sowohl akropetal als auch basipetal aus. Bei "Isabell“ wurden die Bakterien in symptomlosen Stengeln nur über der Inokulationsstelle gefunden.

Zum Zeitpunkt der Temperaturumstellung am 03. 07. 1996 waren nur 18\% der Pflanzen von Isabell und 63\% von Rosario durch $X c p$ befallen (Tab. 10 und Abb. 11), aber Ende 1996 waren bei $15{ }^{\circ} \mathrm{C}$ von "Isabell“ schon 50\% und von "Rosario“ sogar 85\% der Pflanzen erkrankt. 
Von den Pflanzen, die bei 15/25 ${ }^{\circ} \mathrm{C}$ standen, waren bis Ende 1996 67\% bei "Isabell“ und bei "Rosario“ 78\% krank. Die Temperaturerhöhung auf $25^{\circ} \mathrm{C}$ bewirkte in der Anfangsphase eine Beschleunigung der Pathogenese, vor allem bei Isabell (Tab. 10). In den folgenden Jahren nahm dagegen der Krankheitsbefall bei den bei $15{ }^{\circ} \mathrm{C}$ gehalten Pflanzen stärker zu als bei den nach $25^{\circ} \mathrm{C}$ transferierten Pflanzen, insbesondere bei "Rosario“.

So stieg der Befall von "Isabell" bei $15^{\circ} \mathrm{C}$ bis zum 07. 10. 2000 auf 86\%, und bei "Rosario“ sogar auf 100\%, während die wärmer gehaltenen Pflanzen von "Rosario“ nur zu 85\% erkrankten.

Tab. 10 und Abb. 11: Einfluss der Kultivierungstemperatur auf die Reaktion von Pelargonienpflanzen der Sorten "Rosario“ und "Isabell“" nach Stengelinokulation mit $\mathbf{1 0}^{5} \mathbf{c f u} / \mathbf{m l}$. Die Zahlen geben die erkrankten Pflanzen in Prozent aller inokulierten Pflanzen an. Die Pflanzen wurden am 08. 01. 1996 inokuliert.

\begin{tabular}{|r|c|c|c|c|}
\hline $\begin{array}{l}\text { Datum der Pro- } \\
\text { bennahme }\end{array}$ & Isabell $15^{\circ} \mathrm{C}$ & $\begin{array}{l}\text { Isabell Um- } \\
\text { stellung von } 15 \\
{ }^{\circ} \mathrm{C} \text { auf } 25^{\circ} \mathrm{C}\end{array}$ & Rosario $15^{\circ} \mathrm{C}$ & $\begin{array}{l}\text { Rosario } \\
\text { Umstellung von } \\
15^{\circ} \mathrm{C} \text { auf } 25{ }^{\circ} \mathrm{C}\end{array}$ \\
\hline \hline 08.01 .96 & 0 & & 0 & \\
\hline 01.02 .96 & 0 & & 20 & \\
\hline 03.03 .96 & 8 & & 40 & \\
\hline 05.04 .96 & 13 & & 48 & \\
\hline 13.05 .96 & 18 & & 63 & 63 \\
\hline $\mathbf{0 3 . 0 7 . 9 6}$ & 18 & 18 & 63 & 70 \\
\hline 14.08 .96 & 18 & 40 & 70 & 70 \\
\hline 10.09 .96 & 45 & 40 & 85 & 85 \\
\hline 07.10 .96 & 50 & 67 & 85 & 85 \\
\hline 12.11 .97 & 50 & 84 & 100 & 85 \\
\hline 14.10 .99 & 59 & 84 & 100 & 85 \\
\hline 11.11 .99 & 59 & 84 & 100 & 85 \\
\hline 22.05 .00 & 68 & 84 & 100 & 85 \\
\hline 09.07 .00 & 77 & 84 & 100 & 85 \\
\hline 07.10 .00 & 86 & 84 & & \\
\hline 21.07 .01 & 86 & 84 & & \\
\hline
\end{tabular}




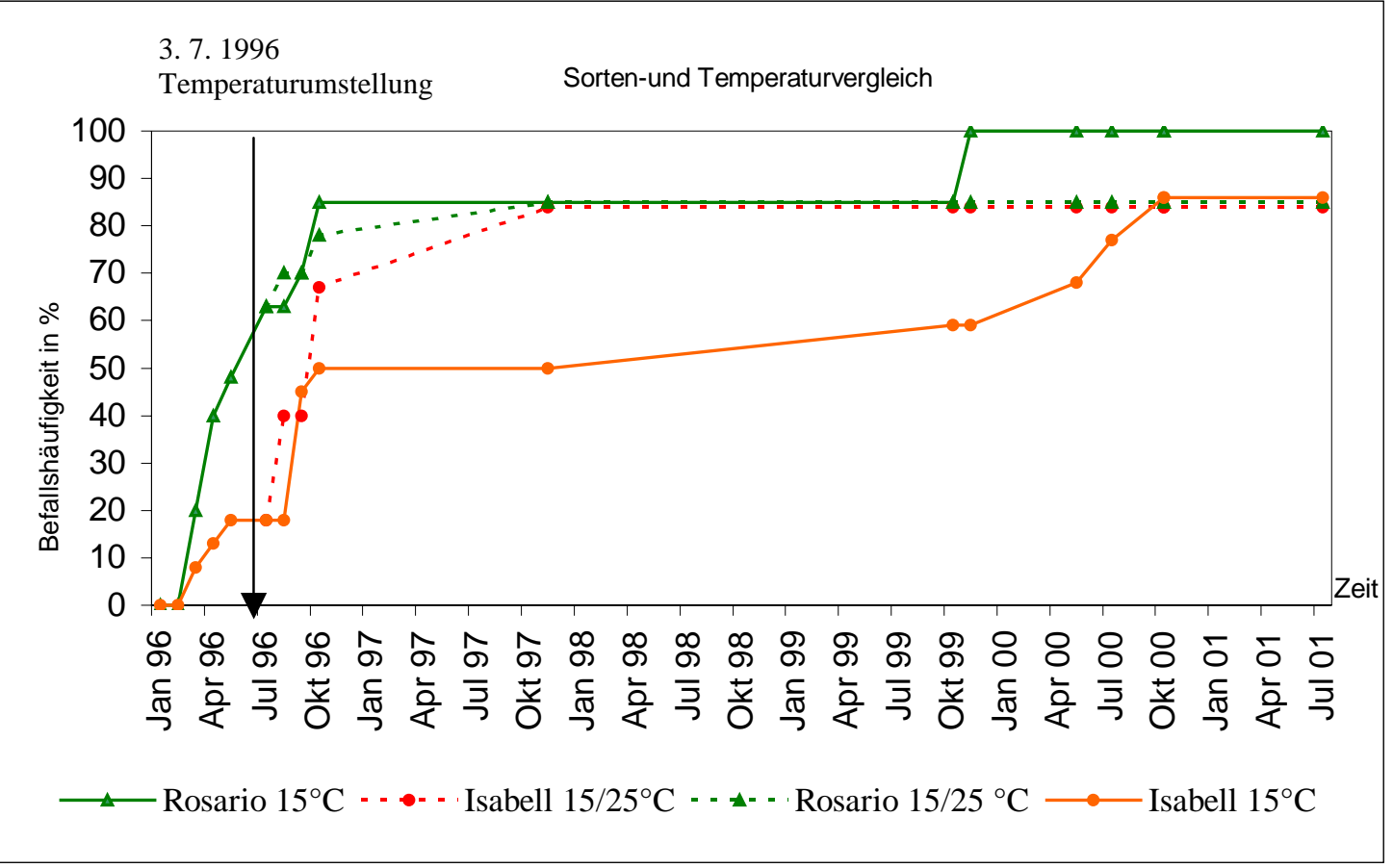

Tab. 11: Mikrobiologischer Nachweis von Xcp (in cfu/g Stengel) in latent befallenen Pelargonienpflanzen nach Stengelinokulation mit $\mathbf{1 0}^{5} \mathbf{c f u} / \mathbf{m l}$ und Aufstellung bei $15^{\circ} \mathrm{C}$ oder $15 / 25^{\circ} \mathrm{C}$

\begin{tabular}{|c|c|c|c|c|c|c|}
\hline \multicolumn{7}{|c|}{$15^{\circ} \mathrm{C}$} \\
\hline \multicolumn{4}{|c|}{ Isabell } & \multicolumn{3}{|c|}{ Rosario } \\
\hline Probenahme & $\mathbf{a}$ & b & c & $\mathbf{a}$ & b & $\mathbf{C}$ \\
\hline 31. 01.1996 & ng & ng & ng & $\begin{array}{l}2 \times 10^{2} \\
5 \times 10^{6}\end{array}$ & $\begin{array}{l}\text { ng } \\
2,6 \times 10^{2}\end{array}$ & $\begin{array}{l}\text { ng } \\
2,8 \times 10^{6}\end{array}$ \\
\hline 15. 02.1996 & $\begin{array}{l}1,2 \times 10^{6} \\
6,3 \times 10^{6}\end{array}$ & $\begin{array}{l}2,8 \times 10^{2} \\
1,7 \times 10^{2}\end{array}$ & $\begin{array}{l}\text { ng } \\
\text { ng }\end{array}$ & $2,6 \times 10^{5}$ & $5 \times 10^{2}$ & $1,5 \times 10^{3}$ \\
\hline 05. 04. 1996 & & & & $1,2 \times 10^{6}$ & ng & $2,2 \times 10^{2}$ \\
\hline 03. 07. 1996 & & & & $6,4 \times 10^{2}$ & ng & ng \\
\hline 07. 10. 1996 & $1,6 \times 10^{3}$ & ng & ng & & & \\
\hline 13.11. 1996 & $2,4 \times 10^{2}$ & $1 \times 10^{5}$ & ng & & & \\
\hline 10.11. 1997 & $1,4 \times 10^{4}$ & ng & ng & & & \\
\hline \multicolumn{7}{|c|}{$15^{\circ} \mathrm{C} / 25^{\circ} \mathrm{C}$} \\
\hline 12. 11. 1997 & $\begin{array}{l}2,4 \times 10^{4} \\
1,8 \times 10^{4}\end{array}$ & $\begin{array}{l}\text { ng } \\
\text { ng }\end{array}$ & $\begin{array}{l}\text { ng } \\
\text { ng }\end{array}$ & & & \\
\hline
\end{tabular}




\subsection{5 $15^{\circ} \mathrm{C}$ und $10^{4} \mathrm{cfu} / \mathrm{ml}$}

Einen Monat nach der Inokulation konnten die markierten Bakterien in symptomlosen Pflanzen nur einmal an der Inokulationsstelle von "Isabell“ (6,4 x $\left.10^{3} \mathrm{cfu} / \mathrm{g}\right)$ isoliert werden. Bei zwei untersuchten Pflanzen von "Rosario“ wurden bereits 7,8 x $10^{5}$ und 1,3 x $10^{3}$ cfu/g Stengelfrischgewicht gefunden. Starke Symptome traten erst drei Monate nach der Inokulation auf. Die Bakterien breiteten sich in der Pflanze systemisch aus (ähnlich wie in Abb. 10 dargestellt). Bei allen untersuchten Proben war die Bakterienkonzentration in den Pflanzen von "Rosario“ höher als in denjenigen von "Isabell“, und die Rosario-Pflanzen zeigten stärkere Symptome.

Sechs Monate nach der Inokulation waren 13\% der Pflanzen von "Isabell“ und 30\% von "Rosario" erkrankt.

Ende 1997 konnten bei symptomlosen Pflanzen die Bakterien nur an der Inokulationsstelle nachgewiesen werden. Die maximalen Bakterienkonzentrationen bei beiden Temperaturen $\left(15^{\circ} \mathrm{C}\right.$ und $25^{\circ} \mathrm{C}$ ) waren fast gleich (“Isabell“ $1,8 \times 10^{3}$ bzw. $2,1 \times 10^{3}$,"Rosario“ $2,8 \times 10^{3}$ bzw. $5,7 \times 10^{3} \mathrm{cfu} / \mathrm{g}$ Frischstengelgewicht).

In den Jahren 1999 und vor allem 2000 wurde eine Befallszunahme nur bei den Pflanzen beider Sorten, die durchgehend bei $15^{\circ} \mathrm{C}$ gehalten wurden, festgestellt. So waren im Oktober 2000 83\% der Isabell-Pflanzen und 91\% von Rosario befallen, während die Befallswerte für die Temperatur 15/25 ${ }^{\circ} \mathrm{C}$ bei 47\% bzw. 65\% lagen (Tab. 12 und Abb. 12). 
Tab. 12 und Abb. 12: $\quad$ Einfluss der Kultivierungstemperatur auf die Reaktion von

Pelargonienpflanzen der Sorten "Rosario“ und "Isabell“ nach Stengelinokulation mit $\mathbf{1 0}^{\mathbf{4}}$

cfu/ml. Die Zahlen geben die erkrankten Pflanzen in Prozent aller inokulierten Pflanzen an. Die Pflanzen wurden am 08. 01. 1996 inokuliert.

\begin{tabular}{|c|c|c|c|c|}
\hline $\begin{array}{l}\text { Datum der Pro- } \\
\text { benahme }\end{array}$ & Isabell $15^{\circ} \mathrm{C}$ & \begin{tabular}{|l}
\multicolumn{1}{c}{ Isabell Um- } \\
stellung von \\
$15^{\circ} \mathrm{C}$ auf $25^{\circ} \mathrm{C}$
\end{tabular} & Rosario $15^{\circ} \mathrm{C}$ & $\begin{array}{l}\text { Rosario Um- } \\
\text { stellung von } \\
15^{\circ} \mathrm{C} \text { auf } 25^{\circ} \mathrm{C}\end{array}$ \\
\hline 08.01 .96 & 0 & & 0 & \\
\hline 06.02 .96 & 0 & & 0 & \\
\hline 03.03 .96 & 3 & & 5 & \\
\hline 05.04 .96 & 8 & & 25 & \\
\hline 13.05 .96 & 13 & & 25 & \\
\hline 03.07.96 & 13 & 13 & 30 & 30 \\
\hline 14.08 .96 & 13 & 36 & 30 & 42 \\
\hline 10.09 .96 & 22 & 42 & 43 & 59 \\
\hline 01.11 .96 & 32 & 42 & 43 & 59 \\
\hline 01.12 .96 & 32 & 42 & 43 & 59 \\
\hline 12.11 .97 & 32 & 47 & 43 & 59 \\
\hline 09.12 .97 & 32 & 47 & 43 & 65 \\
\hline 11.11 .99 & 55 & 47 & 51 & 65 \\
\hline 22.05 .00 & 68 & 47 & 74 & 65 \\
\hline 07.10 .00 & 83 & 47 & 91 & 65 \\
\hline 21.07 .01 & 83 & 47 & 91 & 65 \\
\hline
\end{tabular}

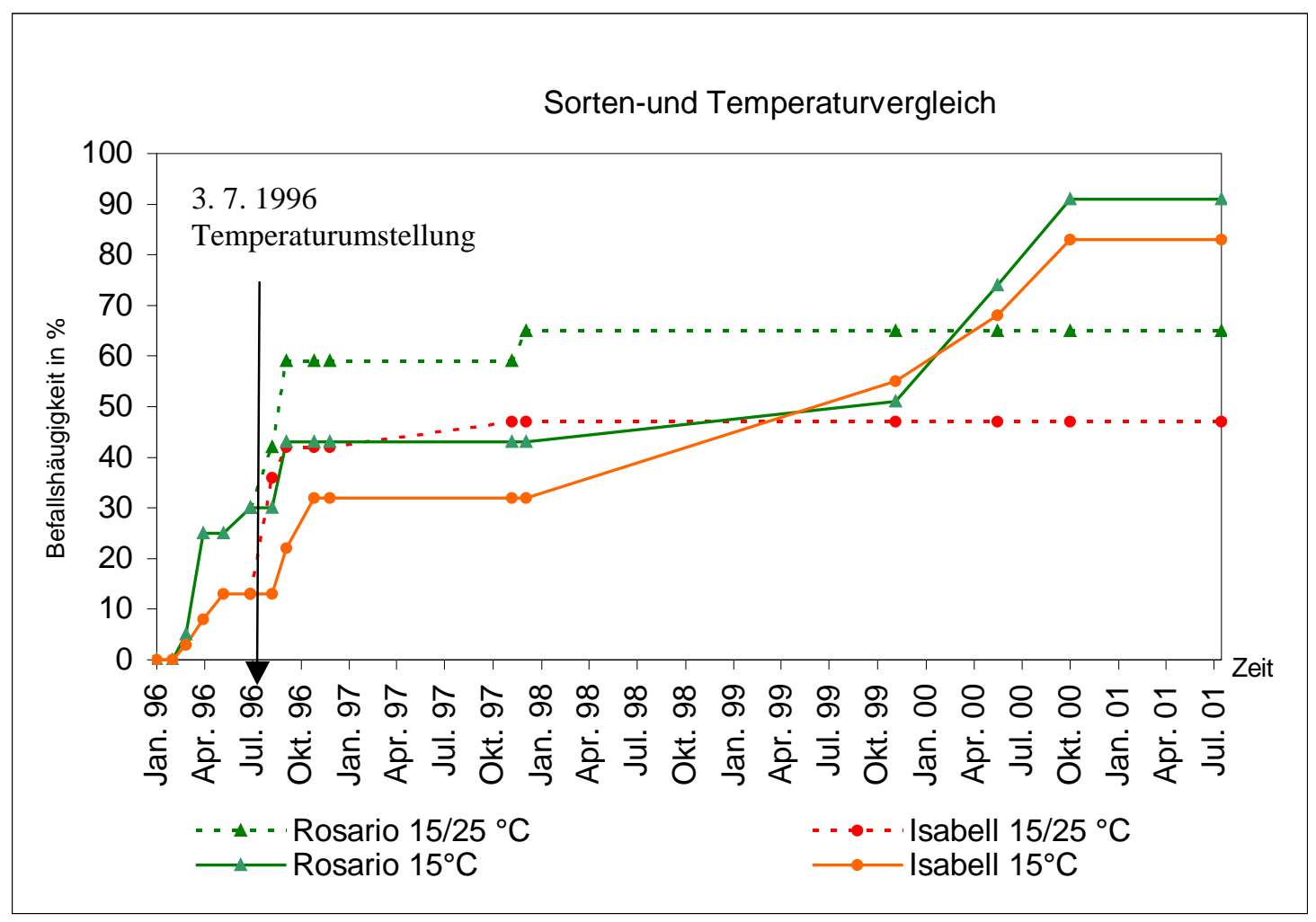


Tab. 13: Mikrobiologischer Nachweis von $X c p$ (in cfu/g Stengel) in latent befallenen Pelargonienpflanzen nach Stengelinokulation mit $\mathbf{1 0}^{\mathbf{4}} \mathbf{c f u} / \mathbf{m l}$ und Aufstellung bei $15^{\circ} \mathrm{C}$ oder $15 / 25^{\circ} \mathrm{C}$

\begin{tabular}{|c|c|c|c|c|c|c|}
\hline \multicolumn{7}{|c|}{$15^{\circ} \mathrm{C}$} \\
\hline \multicolumn{4}{|c|}{ Isabell } & \multicolumn{3}{|c|}{ Rosario } \\
\hline Probenahme & $\mathbf{a}$ & b & C & $\mathbf{a}$ & b & C \\
\hline 31. 01.1996 & $6,4 \times 10^{3}$ & ng & ng & $\begin{array}{l}7,8 \times 10^{5} \\
1,3 \times 10^{3}\end{array}$ & $\begin{array}{l}\text { ng } \\
\text { ng }\end{array}$ & $\begin{array}{l}\text { ng } \\
\text { ng }\end{array}$ \\
\hline 06.02. 1996 & ng & ng & ng & $3 \times 10^{5}$ & $3,5 \times 10^{2}$ & ng \\
\hline 03. 03. 1996 & & & & $1 \times 10^{7}$ & $1,5 \times 10^{3}$ & $2,3 \times 10^{3}$ \\
\hline 03. 07. 1996 & & & & $7,6 \times 10^{4}$ & $1 \times 10^{5}$ & $1 \times 10^{3}$ \\
\hline 14. 08. 1996 & $1,5 \times 10^{5}$ & ng & ng & & & \\
\hline 09. 09. 1996 & & & & $7,4 \times 10^{4}$ & ng & ng \\
\hline 11. 11. 1996 & & & & $2,2 \times 10^{2}$ & ng & ng- \\
\hline 12. 11. 1997 & $\begin{array}{l}2,4 \times 10^{2} \\
1,8 \times 10^{3}\end{array}$ & $\begin{array}{l}\text { ng } \\
\text { ng }\end{array}$ & $\begin{array}{l}\text { ng } \\
\text { ng }\end{array}$ & $\begin{array}{l}5,2 \times 10^{2} \\
2,8 \times 10^{3}\end{array}$ & $\begin{array}{l}\text { ng } \\
\text { ng }\end{array}$ & $\begin{array}{l}\text { ng } \\
\text { ng }\end{array}$ \\
\hline \multicolumn{7}{|c|}{$15^{\circ} \mathrm{C} / 25^{\circ} \mathrm{C}$} \\
\hline 10.09. 1996 & $\begin{array}{l}1,8 \times 10^{2} \\
5 \times 10^{2}\end{array}$ & $\begin{array}{l}\text { ng } \\
\text { ng }\end{array}$ & $\begin{array}{l}\text { ng } \\
\text { ng }\end{array}$ & $1,4 \times 10^{3}$ & ng & ng \\
\hline 01. 12. 1996 & $2,6 \times 10^{2}$ & ng & ng & & & \\
\hline 12. 11. 1997 & $2,1 \times 10^{3}$ & ng & ng & $5,7 \times 10^{3}$ & ng & $1 \times 10^{3}$ \\
\hline 09. 12.1997 & & & & $9,2 \times 10^{2}$ & ng & ng \\
\hline
\end{tabular}

\subsection{6 $15^{\circ} \mathrm{C}$ und $10^{3} \mathrm{cfu} / \mathrm{ml}$}

Die ersten Krankheitssymptome traten bei "Rosario“ 2 Monate und bei "Isabell“ 4 Monate nach Inokulation auf (Tab. 14 und Abb. 13). In einer erkrankten Pflanze von "Rosario" wurden die markierten Bakterien 3 Monate nach Inokulation überall gefunden (ähnlich wie in Abb. 10 dargestellt). Ganz ähnliche Ergebnisse wurden für eine erkrankte Pflanze von “Isabell“" gewonnen (Abb. 14). 
In gesunden Pflanzen (Tab. 13) wurden zum ersten Mal 2 Monate nach Inokulation bei "Isabell“ (1,2 x $10^{2}$ cfu/g Frischgewicht) und 4 Monate nach Inokulation bei "Rosario“ (5,4 x $10^{3} \mathrm{cfu} / \mathrm{g}$ Frischgewicht) die Bakterien gefunden. Nur bei Rosario waren in symptomlosen Pflanzen auch zweimal oberhalb und einmal unterhalb der Inokulationsstelle gesunder Pflanzen die Bakterien nachweisbar (Tab. 15).

Nach der Temperaturumstellung waren bei Isabell 3\% und Rosario 5\% der Pflanzen erkrankt, während Ende 1996 der Befall bei Isabell auf 13\% und bei Rosario auf 11\% anstieg (Tab. 14 und Abb. 13).

In den Jahren 1997 und 1998 zeigten die restlichen Pflanzen von "Isabell“ keine neuen Symptome. Dagegen nahm bei “Rosario“ der Befall Ende 1997 etwa um das Doppelte auf 24\% zu. Erst im Jahr 2000 nahm die Krankheit an beiden Sorten bei der kühlen Temperatur in relativ kurzer Zeit wesentlich zu und erreichte am 07. 10. 2000 Werte von 80\% für Isabell und 100\% bei Rosario-Pflanzen, während bei den warm gehaltenen Pflanzen (15/25) sowohl Isabell als auch Rosario keine weiteren Krankheitsfälle auftraten (Tab. 14). Die Pflanzen zeigten erst einseitige Welke und innerhalb von einem Monat wurden die ganzen Pflanzen befallen. Auch diese Versuchsvariante zeigte wieder, dass die Gefahr eines latenten Befalls bei der niedrigen Inkubationstemperatur von $15{ }^{\circ} \mathrm{C}$ besonders hoch ist. Es stellt sich die Frage, warum die Latenzphase nicht bei den Pflanzen durchbrochen wurde, die bei $25^{\circ} \mathrm{C}$ standen, obwohl im Jahr 1996 in etwa der gleichen Zahl von Fällen latent vorkommende Bakterien festgestellt wurden (Tab. 15). Bei $15^{\circ} \mathrm{C}$ war die Ausbreitung von $X c p$ in der Pflanze viel langsamer und Symptome traten erst ab einer Bakterienpopulation von $10^{7} \mathrm{cfu} / \mathrm{g}$ Frischgewicht auf. 
Tab. 14 und Abb. 13: Einfluss der Kultivierungstemperatur auf die Reaktion von Pelargonienpflanzen der Sorten "Rosario" und "Isabell" nach Stengelinokulation mit $\mathbf{1 0}^{3} \mathbf{c f u} / \mathbf{m l}$. Die Zahlen geben die erkrankten Pflanzen in Prozent aller inokulierten Pflanzen an. Die Pflanzen wurden am 08. 01. 1996 inokuliert.

\begin{tabular}{|c|c|c|c|c|}
\hline $\begin{array}{l}\text { Datum der Pro- } \\
\text { bennahme } \\
08.01 .96 \\
\end{array}$ & Isabell $15^{\circ} \mathrm{C}$ & $\begin{array}{c}\text { Isabell } \\
\text { Umstellung von } \\
15^{\circ} \mathrm{C} \text { auf } 25^{\circ} \mathrm{C}\end{array}$ & $\begin{array}{c}\text { Rosario } 15^{\circ} \mathrm{C} \\
0 \\
\end{array}$ & $\begin{array}{l}\text { Rosario Um- } \\
\text { stellung von } 15 \\
{ }^{\circ} \mathrm{C} \text { auf } 25^{\circ} \mathrm{C}\end{array}$ \\
\hline 06.02 .96 & 0 & & 0 & \\
\hline 03.03 .96 & 0 & & 3 & \\
\hline 05.04 .96 & 0 & & 3 & \\
\hline 13.05 .96 & 3 & & 3 & \\
\hline 03.07 .96 & 3 & 3 & 5 & 5 \\
\hline 14.08 .96 & 3 & 8 & 11 & 15 \\
\hline 10.09 .96 & 3 & 8 & 11 & 15 \\
\hline 07.10 .96 & 13 & 19 & 11 & 19 \\
\hline 07.11 .96 & 13 & 19 & 11 & 19 \\
\hline 12.11 .97 & 13 & 19 & 24 & 38 \\
\hline 17.12 .97 & 13 & 19 & 24 & 38 \\
\hline 17.11.97 & 13 & 19 & 24 & 38 \\
\hline 14.10 .99 & 13 & 19 & 24 & 38 \\
\hline 11.11 .99 & 13 & 19 & 37 & 38 \\
\hline 22.05 .00 & 44 & 19 & 49 & 38 \\
\hline 22.06 .00 & 44 & 19 & 75 & 38 \\
\hline 21.07 .00 & 54 & 19 & 75 & 38 \\
\hline 07.10 .00 & 80 & 19 & 94 & 38 \\
\hline 10.07 .01 & 80 & 19 & 100 & 38 \\
\hline
\end{tabular}

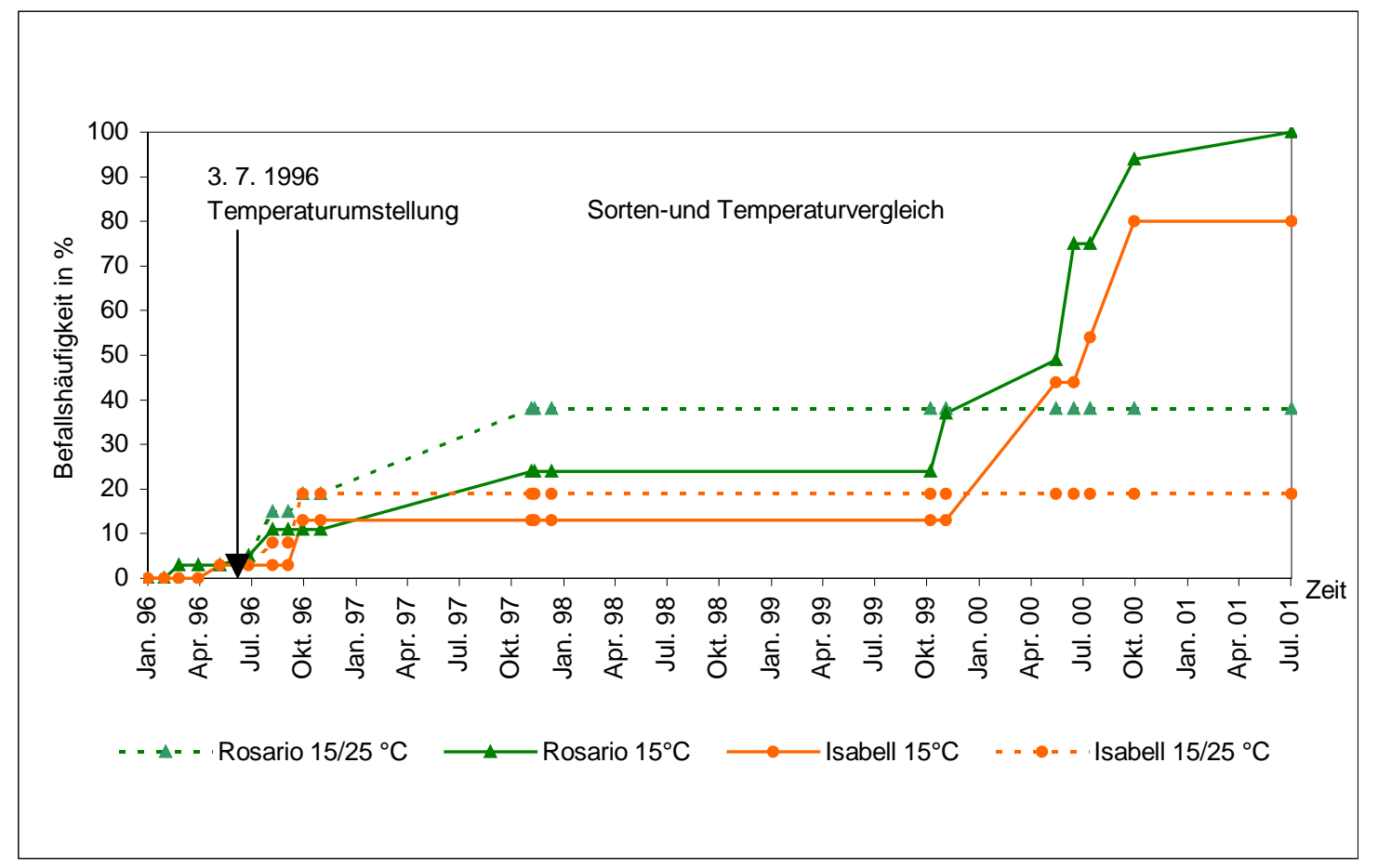


Abb. 14: Ausbreitung von $X c p$ in einer Pelargonienpflanze der Sorte „Isabell“ und im Sickerwasser 3 Monate nach Inokulation mit ca. 100 Bakterienzellen an der mit Links* 1 bezeichneten Stelle, Inkubation bei $15{ }^{\circ} \mathrm{C}$ und $60 \%$ relativer Luftfeuchtigkeit.

\section{Pflanzenprobe}

Rechts 1

R 2

$\mathrm{R} \quad 3$

$\mathrm{R} \quad 4$

Links * 1

L 2

L 3

L 4

L 5

Blütenstengel 1

Blütenstengel 2

Dolden

Trockene Blütenstengel

Wurzeln 1

Wurzeln 3

Wurzeln 2

gemischte Erde

ungemischte Erde

Sickerwasser

\section{Dichte $\mathbf{c f u} / \mathbf{g}$}

$1,5 \times 10^{8}$

$6,4 \times 10^{7}$

$8,8 \times 10^{7}$

$>10^{8}$

$1,5 \times 10^{8}$

$2,3 \times 10^{8}$

$2 \times 10^{7}$

$2,3 \times 10^{8}$

$2,1 \times 10^{8}$

$3,2 \times 10^{2}$

$1 \times 10^{1}$

$4 \times 10^{0}$

$>10^{8}$

$5,6 \times 10^{6}$

$1,2 \times 10^{8}$

$4 \times 10^{7}$

$7,4 \times 10^{4}$

$1 \times 10^{5}$

$2 \times 10^{1}$

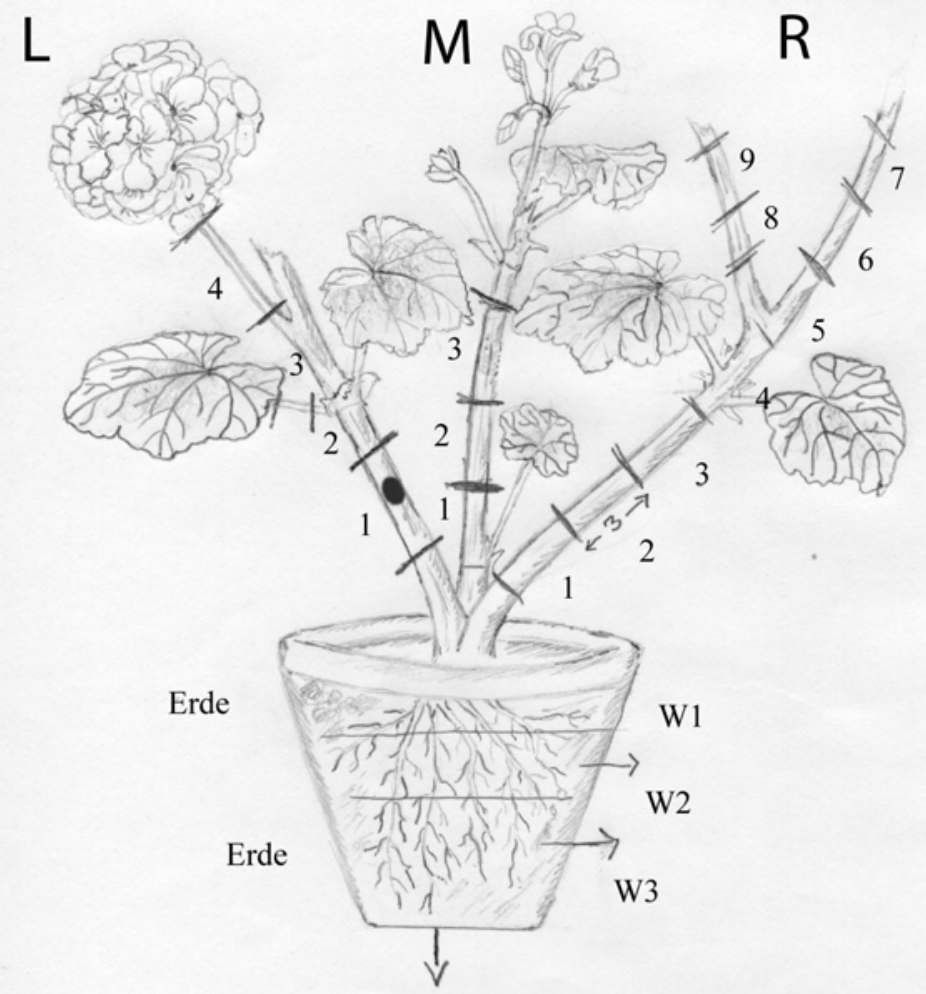


Tab. 15: Mikrobiologischer Nachweis von $X c p$ (in cfu/g Stengel) in latent befallenen Pelargonienpflanzen nach Stengelinokulation mit $\mathbf{1 0}^{3} \mathbf{c f u} / \mathbf{m l}$ und Aufstellung bei $15^{\circ} \mathrm{C}$ oder $15 / 25^{\circ} \mathrm{C}$

\begin{tabular}{|c|c|c|c|c|c|c|}
\hline \multicolumn{7}{|c|}{$15^{\circ} \mathrm{C}$} \\
\hline \multicolumn{4}{|c|}{ Isabell } & \multicolumn{3}{|c|}{ Rosario } \\
\hline Probenahme & $\mathbf{a}$ & b & C & $\mathbf{a}$ & b & C \\
\hline 03. 03. 1996 & $1 \times 10^{2}$ & ng & ng & & & \\
\hline 13. 05.1996 & $1 \times 10^{2}$ & ng & ng & $5,4 \times 10^{3}$ & $6,3 \times 10^{3}$ & $1,2 \times 10^{3}$ \\
\hline 07. 10. 1996 & $1,7 \times 10^{3}$ & ng & ng & $3,6 \times 10^{2}$ & ng & ng \\
\hline 07.11. 1996 & $3,8 \times 10^{4}$ & ng & ng & ng & ng & ng \\
\hline 14. 08.1996 & $1 \times 10^{5}$ & ng & $4 \times 10^{2}$ & & & \\
\hline \multicolumn{7}{|c|}{$15^{\circ} \mathrm{C} / 25^{\circ} \mathrm{C}$} \\
\hline 14. 08.1996 & $4,4 \times 10^{3}$ & ng & ng & $1,4 \times 10^{3}$ & $2,3 \times 10^{3}$ & ng \\
\hline 07. 09. 1996 & $1,7 \times 10^{3}$ & ng & ng & $1,2 \times 10^{2}$ & ng & ng \\
\hline
\end{tabular}

\subsubsection{Zusammenfassung der Ergebnisse des Langzeitversuches}

Zusammengefasst lassen sich die Ergebnisse des Langzeitversuches von Kapitel 3.3 wie folgt beschreiben:

\subsubsection{Inokulumskonzentration}

In fast allen Versuchsgliedern entwickelte sich die Krankheit am schnellsten bei der höchsten Inokulumkonzentration von $10^{5} \mathrm{cfu} / \mathrm{ml}$ und am langsamsten bei der niedrigsten von $10^{3}$ $\mathrm{cfu} / \mathrm{ml}$.

Bemerkenswert ist, dass die Krankheit bei dem niedrigen Inokulum überhaupt ausgelöst wurde; denn die infiltrierten $10 \mu \mathrm{l}$ enthielten nur zwischen 1 - 6 Bakterienzellen (Kap. 3.2). Deswegen trat eine lang andauernde, unerkannte Latenz bei diesem äußerst niedrigen Inokulum besonders häufig auf (Tab. 17). 


\subsubsection{Sortenvergleich}

Die Sorte "Rosario“ reagierte anfälliger als "Isabell“. D. h. in allen Versuchsgliedern erkrankten zu den verschiedenen Terminen jeweils mehr Pflanzen von Rosario als von Isabell. Außerdem erkrankten die Pflanzen von “Rosario“ schneller als diejenigen von „Isabel“. Diese Unterschiede wurden besonders deutlich bei der mittleren Inokulumskonzentration von $10^{4} \mathrm{cfu} / \mathrm{ml}$ und nach 6 Monaten (Tab. 16). In beiden Sorten breiteten sich die Bakterien akropetal und basipetal in der Pflanze aus.

\subsubsection{Einfluss der Temperatur}

a) Bei Temperaturkonstanz: Bei $25^{\circ} \mathrm{C}$ erkrankten die Pflanzen zunächst viel schneller als bei $15^{\circ} \mathrm{C}$. Bei $15^{\circ} \mathrm{C}$ erfolgte die Erkrankung dagegen langsamer, war aber kontunierlicher. Dieser unterschiedliche Einfluss der Temperatur zeigt sich besonders deutlich, wenn man die Zahl der erkrankten Pflanzen 6 Monate und 66 Monate nach Inokulation vergleicht (Tab. 16). Sechs Monate nach Inokulation waren in allen Versuchsgliedern deutlich mehr Pflanzen bei $25^{\circ} \mathrm{C}$ erkrankt als bei $15{ }^{\circ} \mathrm{C}$, aber 66 Monate nach Inokulation war es immer umgekehrt. Die Zunahme der Erkrankungen der bei $15^{\circ} \mathrm{C}$ gehaltenen Pflanzen erfolgte erst recht spät, nämlich 4 Jahre nach Inokulation, wie die Abb. 4, 5, 6, 8, 9 und 10 eindrucksvoll belegen.

Tab. 16: Zahl der erkrankten Pelargonienpflanzen in Prozent 6 und 66 Monate nach Inokulation (Zusammenfassung aus Tabellen 4, 6, 8, 10, 11, 12 und 14).

\begin{tabular}{c|c||l|l||c|c}
\hline \multicolumn{2}{c||}{} & \multicolumn{2}{c}{ Isabell } & \multicolumn{2}{c}{ Rosario } \\
\hline \hline $\begin{array}{c}\text { Inokulums- } \\
\text { konzentration }\end{array}$ & $\begin{array}{l}\text { Monate nach } \\
\text { Inokulation }\end{array}$ & $25^{\circ} \mathrm{C}$ & $15^{\circ} \mathrm{C}$ & $25^{\circ} \mathrm{C}$ & $15^{\circ} \mathrm{C}$ \\
\hline \hline \multirow{2}{*}{$10^{5}$} & 6 & 70 & 18 & 83 & 63 \\
& 66 & 83 & 86 & 83 & 100 \\
\hline \hline \multirow{2}{*}{$10^{4}$} & 6 & 15 & 13 & 33 & 30 \\
& 66 & 60 & 83 & 73 & 91 \\
\hline \multirow{2}{*}{$10^{3}$} & 6 & 5 & 3 & 13 & 5 \\
& 66 & 42 & 80 & 65 & 100 \\
\hline
\end{tabular}


b) Bei Temperaturwechsel 6 Monate nach Inokulation: In den Versuchen mit Temperaturumstellung (entweder von $15^{\circ} \mathrm{C}$ nach $25^{\circ} \mathrm{C}$ oder von $25^{\circ} \mathrm{C}$ nach $15{ }^{\circ} \mathrm{C}$ ) wurden im wesentlichen die gleichen Ergebnisse erzielt wie bei Temperatur-Konstanz. D. h. in der Anfangsphase mit $25{ }^{\circ} \mathrm{C}$ wurde eine Beschleunigung der Pathogenese festgestellt, welche durch die Umstellung auf $15{ }^{\circ} \mathrm{C}$ zunächst abgebremst wurde. Nach 4 Jahren kam es auch hier zu weiteren Krankheitsausbrüchen. Umgekehrt verlief die Pathogenese bei 6 Monaten $15{ }^{\circ} \mathrm{C}$ zunächst langsam und wurde durch die folgende Umstellung auf $25^{\circ} \mathrm{C}$ stark beschleunigt. Aber hier gab es nicht die zusätzlichen Krankheitsausbrüche nach 4 Jahren Latenz.

\subsubsection{Einfluss der Düngung}

Ab August 1998 wurden die Pflanzen wöchentlich mit 1\% Hakaphos gedüngt, nachdem die Pflanzen vorher (1996 - 1998) nur alle 2 Monate mit 1\% Hakaphos gedüngt worden waren. Durch die Nährstoffzugabe kann es zu einer Wachstumsstimulation, die wahrscheinlich die Latenzphase des Befalls bei der $15{ }^{\circ} \mathrm{C}$-Variante unterbrach und später (allerdings erst im Jahre 2000) zur Befallszunahme mit sichtbaren Symptomen führte.

\subsubsection{Dauer der maximalen Latenz}

Wie Tab. 17 zeigt, hatte die Temperatur einen entscheidenden Einfluss auf die Dauer der Latenz. Bei der kühleren Temperatur $\left(15^{\circ} \mathrm{C}\right.$ oder $\left.25 / 15^{\circ} \mathrm{C}\right)$ betrug die maximale Latenzperiode 45 - 57 Monate, dagegen bei der höheren Temperatur $\left(25^{\circ} \mathrm{C}\right.$ oder $\left.15 / 25{ }^{\circ} \mathrm{C}\right)$ nur 3 - 11 Monate (nur in einem Fall 22 Monate). Wenn die Pflanzen in der Anfangsphase von 6 Monaten zunächst bei einer anderen Temperatur gehalten wurden, hatte diese nur einen geringen Einfluss auf die maximale Latenz, wie sich bei einem Vergleich der Versuchsglieder $25^{\circ} \mathrm{C}$ mit $15 / 25^{\circ} \mathrm{C}$ und $15^{\circ} \mathrm{C}$ mit $25 / 15^{\circ} \mathrm{C}$ zeigt. Zwischen den beiden Sorten "Isabell“ und "Rosario“ konnten keine deutlichen Unterschiede in der Dauer der Latenz festgestellt werden. 
Tab. 17: Maximale Latenzperiode in Monaten

\begin{tabular}{|c|c|c|c|c|c|}
\hline Sorte & Inokulum & $25^{\circ} \mathrm{C}$ & $15 / 25^{\circ} \mathrm{C}$ & $15^{\circ} \mathrm{C}$ & $25 / 15^{\circ} \mathrm{C}$ \\
\hline \multirow[t]{3}{*}{ Isabell } & $10^{5}$ & 9 & 9 & 54 & 46 \\
\hline & $10^{4}$ & 11 & 11 & 53 & 54 \\
\hline & $10^{3}$ & 10 & 8 & 54 & 46 \\
\hline \multirow[t]{3}{*}{ Rosario } & $10^{5}$ & 3 & 9 & 45 & 54 \\
\hline & $10^{4}$ & 11 & 22 & 53 & 54 \\
\hline & $10^{3}$ & 10 & 10 & 57 & 54 \\
\hline
\end{tabular}

\subsubsection{Schwelle der Bakterienkonzentration in der Pflanze, die zu Symptomen führte}

In Tab. 18 ist zusammengestellt, wie oft in gesunden Pelargonienstengeln verschiedene Bakterienkonzentrationen festgestellt wurden. In der weitaus überwiegenden Zahl der Fälle, d. h. in $\mathbf{7 6 \%}$, wurden in diesen latent befallenen Stengeln nur zwischen $\mathbf{1 0}^{\mathbf{2}}$ und $\mathbf{1 0}^{\mathbf{3}}$ cfu/g Frischgewicht gefunden. Die wenigen höheren Werte, insbesondere $10^{6}$ und $10^{7}$ cfu/g Frischgewicht, stammten wahrscheinlich aus Pflanzen, bei denen die Bakterien schon die Latenzphase durchbrochen hatten, ohne dass bereits deutliche Krankheitssymptome auftraten. Bei $10^{6}$ - $10^{7} \mathrm{cfu} / \mathrm{g}$ war z. T. an der Blattfärbung zu erkennen, dass die Pflanzen bald deutliche Symptome zeigen würden. Erst ab $10^{8} \mathrm{cfu} / \mathrm{g}$ entwickelten sich starke Symptome. 
Tab. 18: Bakterienkonzentrationen in latent befallenen Pelargonienstengeln. Die Tabelle zeigt, wie oft die verschiedenen Bakterienkonzentrationen (nach Zehnerpotenzen geordnet) bei den einzelnen Versuchsgliedern festgestellt wurden (zusammengefasst aus Tabellen 5, $7,9,11,13$ und 15).

\begin{tabular}{c|c|c|c||c|c|c||c|c}
\multicolumn{1}{c||}{} & \multicolumn{3}{c||}{$25^{\circ} \mathrm{C}$} & \multicolumn{3}{c||}{$15^{\circ} \mathrm{C}$} & \multicolumn{2}{c}{ Summe } \\
\hline $\begin{array}{c}\text { Bakterien- } \\
\text { konzentration im Stengel }\end{array}$ & $10^{5}$ & $10^{4}$ & $10^{3}$ & $10^{5}$ & $10^{4}$ & $10^{3}$ & absolut & $\%$ \\
\hline $10^{2}$ & 1 & 11 & 8 & 5 & 7 & 4 & 36 & 38 \\
\hline $10^{3}$ & 6 & 14 & 3 & 1 & 7 & 5 & 36 & 38 \\
\hline $10^{4}$ & 4 & 5 & 1 & 3 & 2 & 1 & 16 & 17 \\
\hline $10^{5}$ & 3 & 2 & - & 2 & 3 & 1 & 11 & 11 \\
\hline $10^{6}$ & 1 & - & - & 4 & - & - & 5 & 5 \\
\hline $10^{7}$ & - & - & - & - & 1 & - & 1 & 1 \\
\hline
\end{tabular}

X): ausgedrückt in cfu/g Stengelfrischgewicht

\subsubsection{Bakterienvorkommen in erkrankten Pflanzen}

Die in latent befallenen, äußerlich gesund erscheinenden Pflanzen nachgewiesenen Bakterienzahlen für alle Versuchsglieder zeigen die Tab. 5, 7, 9, 13 und 15. Eine Zusammenfassung dieser Zahlen ergibt sich aus Tab. 18.

Auch in Pflanzen mit typischen Krankheitssymptomen wurden die Bakterienkonzentrationen häufig und in verschiedenen Pflanzenteilen bestimmt. Exemplarisch sind die Befunde für 2 Versuchsglieder in den Abb. 7 und $\mathbf{1 1}$ dargestellt. Hier wurden recht hohe Bakterienkonzentrationen bestimmt, z. B. bei "Rosario“ im Stengell maximal 5,8 x $10^{9} \mathrm{cfu} / \mathrm{g}$, bei "Isabell“ nur 2,3 x $10^{8} \mathrm{cfu} / \mathrm{g}$. Hohe Bakterienkonzentrationen ( $\left.>10^{8} \mathrm{cfu} / \mathrm{g}\right)$ wurden bei beiden Sorten auch in anderen Pflanzenorganen gefunden, d. h. in den Blütenknospen, den vertrockneten Blütendolden und sogar in den Wurzeln. 
Tab. 19: Gefundene maximale Bakterienkonzentrationen (cfu/g Stengelfrischgewicht) in deutlich erkrankten Pflanzen aus A: Stengeln mit starken Krankheitssymptomen oder $\boldsymbol{B}$ : Stengeln noch ohne Krankheitssymptome

\begin{tabular}{|c|c|c|c|c|c|}
\hline & & & oell & & ario \\
\hline $\begin{array}{l}\text { Monate nach } \\
\text { Inokulation }\end{array}$ & $\begin{array}{l}\text { Inokulums- } \\
\text { konzentration }\end{array}$ & A & B & A & $B$ \\
\hline 0,5 & $10^{3}$ & & & $8,0 \times 10^{8}$ & $7,5 \times 10^{5}$ \\
\hline & $10^{4}$ & $4,3 \times 10^{8}$ & $7,1 \times 10^{7}$ & $3,7 \times 10^{9}$ & $8,0 \times 10^{8}$ \\
\hline & $10^{5}$ & $2,8 \times 10^{9}$ & $>10^{8}$ & $8,3 \times 10^{10}$ & $9,2 \times 10^{8}$ \\
\hline 1 & $10^{5}$ & $2,9 \times 10^{9}$ & $2,0 \times 10^{7}$ & & \\
\hline 2 & $10^{3}$ & & & $1,6 \times 10^{9}$ & $6,1 \times 10^{7}$ \\
\hline & $10^{4}$ & & $2,0 \times 10^{8}$ & $1,3 \times 10^{10}$ & $3,1 \times 10^{8}$ \\
\hline & $10^{5}$ & $3,0 \times 10^{9}$ & $5,0 \times 10^{7}$ & $5,6 \times 10^{9}$ & $3,0 \times 10^{8}$ \\
\hline 3 & $10^{4}$ & $1,5 \times 10^{8}$ & $2,0 \times 10^{7}$ & $6,3 \times 10^{9}$ & $8,0 \times 10^{7}$ \\
\hline & $10^{5}$ & $9,5 \times 10^{9}$ & $3,3 \times 10^{8}$ & $8,3 \times 10^{10}$ & $4,7 \times 10^{8}$ \\
\hline 4 & $10^{3}$ & $1,5 \times 10^{8}$ & $4,9 \times 10^{3}$ & $1,8 \times 10^{8}$ & $1,4 \times 10^{2}$ \\
\hline & $10^{4}$ & $3,4 \times 10^{9}$ & $1,5 \times 10^{7}$ & & \\
\hline & $10^{5}$ & $1,0 \times 10^{9}$ & $2,1 \times 10^{7}$ & $1,2 \times 10^{9}$ & $3,1 \times 10^{7}$ \\
\hline 6 & $10^{3}$ & $7,5 \times 10^{7}$ & $1,7 \times 10^{2}$ & $1,3 \times 10^{8}$ & $4,2 \times 10^{7}$ \\
\hline & $10^{5}$ & $2,2 \times 10^{9}$ & $7,6 \times 10^{7}$ & & \\
\hline 7 & $10^{3}$ & $3,4 \times 10^{7}$ & $5,0 \times 10^{8}$ & $5,3 \times 10^{8}$ & $4,3 \times 10^{8}$ \\
\hline & $10^{4}$ & $2,5 \times 10^{9}$ & $4,0 \times 10^{1}$ & $1,4 \times 10^{8}$ & $8,0 \times 10^{7}$ \\
\hline 8 & $10^{3}$ & & & $1,2 \times 10^{9}$ & $1,6 \times 10^{7}$ \\
\hline & $10^{4}$ & $3,5 \times 10^{9}$ & $6,6 \times 10^{7}$ & $3,2 \times 10^{8}$ & $2,5 \times 10^{6}$ \\
\hline & $10^{5}$ & & & $1,9 \times 10^{8}$ & $2,7 \times 10^{6}$ \\
\hline
\end{tabular}




\begin{tabular}{|c|c|c|c|c|c|}
\hline & & & bell & & ario \\
\hline $\begin{array}{l}\text { Monate nach } \\
\text { Inokulation }\end{array}$ & $\begin{array}{l}\text { Inokulums- } \\
\text { konzentration }\end{array}$ & A & $B$ & A & $B$ \\
\hline 9 & $10^{3}$ & $8,3 \times 10^{8}$ & & $4,5 \times 10^{7}$ & $5,5 \times 10^{6}$ \\
\hline & $10^{4}$ & $3,5 \times 10^{9}$ & $2,5 \times 10^{7}$ & $3,0 \times 10^{9}$ & $1,5 \times 10^{6}$ \\
\hline & $10^{5}$ & $1,9 \times 10^{8}$ & & $4,8 \times 10^{9}$ & $5,0 \times 10^{7}$ \\
\hline 10 & $10^{4}$ & $5,6 \times 10^{7}$ & $3,0 \times 10^{6}$ & & \\
\hline 22 & $10^{3}$ & & & $5,3 \times 10^{7}$ & $1,5 \times 10^{6}$ \\
\hline 46 & $10^{3}$ & $1,0 \times 10^{9}$ & $3,0 \times 10^{4}$ & $5,2 \times 10^{6}$ & $5,0 \times 10^{2}$ \\
\hline & $10^{4}$ & $1,5 \times 10^{8}$ & $8,0 \times 10^{6}$ & $3,6 \times 10^{8}$ & \\
\hline & $10^{5}$ & $2,1 \times 10^{7}$ & $1,0 \times 10^{6}$ & & $3,1 \times 10^{7}$ \\
\hline 52 & $10^{3}$ & $4,2 \times 10^{7}$ & & $1,6 \times 10^{6}$ & \\
\hline & $10^{4}$ & $1,4 \times 10^{6}$ & $4,1 \times 10^{5}$ & $3,8 \times 10^{6}$ & \\
\hline & $10^{5}$ & $8,8 \times 10^{5}$ & $9,4 \times 10^{6}$ & $3,7 \times 10^{7}$ & \\
\hline 53 & $10^{3}$ & $2,0 \times 10^{7}$ & & $1,1 \times 10^{8}$ & $4,9 \times 10^{6}$ \\
\hline & $10^{4}$ & $1,7 \times 10^{8}$ & $2,3 \times 10^{3}$ & $5,4 \times 10^{7}$ & \\
\hline 57 & $10^{3}$ & $6,0 \times 10^{5}$ & & $7,9 \times 10^{7}$ & $2,2 \times 10^{3}$ \\
\hline 68 & $10^{3}$ & & & $7,5 \times 10^{4}$ & $7,4 \times 10^{3}$ \\
\hline
\end{tabular}

Die Ergebnisse aller übrigen Bakterienbestimmungen in deutlich erkrankten Pflanzen sind in Tab. 19 in soweit zusammengefasst, dass nur die jeweils gefundenen maximalen Bakterienzahlen für die verschiedenen Versuchsglieder im Zeitraum von 0,5 bis 68 Monate nach Inokulation wiedergegeben werden. Dabei wurde bei den beiden Sorten jeweils unterschieden zwischen Stengelproben mit starken Krankheitssymptomen (A) und Stengelproben derselben Pflanzen, aber noch ohne deutliche Symptome (B). Aus Tab. 19 geht hervor, dass:

- bei "Rosario“ innerhalb der ersten 3 - 4 Monate etwa 10-fach höhere Bakterienkonzentrationen vorkamen (maximal 8,3 x $10^{10} \mathrm{cfu} / \mathrm{g}$ Frischgewicht) als bei "Isabell“ (maximal 9,5 $\times 10^{9}$ ), 
- auch in den noch symptomlosen Stengeln hohe Bakterienkonzentrationen vorhanden waren (Rosario: 9,2 $\times 10^{8}$, Isabell: $5 \times 10^{8}$ ),

- im Verlaufe des Versuches die maximalen Bakterienzahlen im kranken Gewebe abnahmen (nach 68 Monaten bei Isabell nur noch 7,5 x 10 $\mathrm{cfu} / \mathrm{g}$ Frischgewicht).

Außerdem wurde in mehreren Fällen untersucht, ob die Bakterienbesiedlung der Stengel unterschiedlich war, wenn das Vorkommen in Nodien und Internodien verglichen wurde. Abb. 15 zeigt exemplarisch die Ergebnisse für eine Pelargonienpflanze ohne Krankheitssymptome, die am 08. 01. $1996 \mathrm{mit} 10^{4} \mathrm{cfu} / \mathrm{ml}$ inokuliert und bei $15{ }^{\circ} \mathrm{C}$ aufgestellt wurde. Am 01. 11. 1999, d. h. nach 46 Monaten, waren in allen drei Nodien mit Bakterienbefall die Konzentrationen um eine Zehnerpotenz höher als in den Internodien darüber oder darunter.

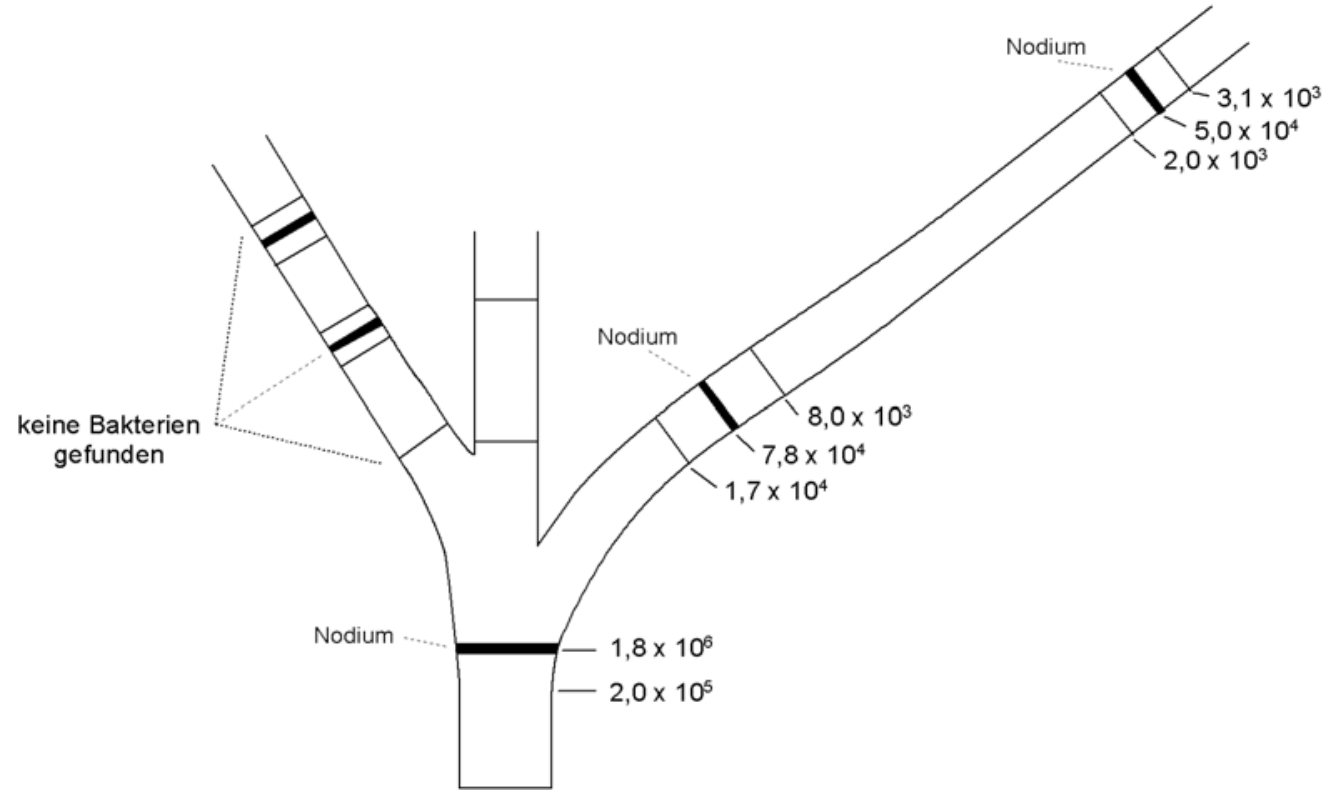

Abb. 15: Bakterienkonzentrationen (in $\mathrm{cfu} / \mathrm{g}$ ) in Nodien (dicker schwarzer Strich) und Internodien einer Pelargonienpflanze ("Rosario“), die am 08. 01. $1996 \mathrm{mit} 10^{4} \mathrm{cfu} / \mathrm{ml}$ inokuliert und seitdem 46 Monate bei $15^{\circ} \mathrm{C}$ aufgestellt wurde. 


\subsection{Untersuchungen zu möglichen Infektionswegen}

\subsection{1 Über das Blatt}

Der Versuchsaufbau ist in 2.9.1 beschrieben. Die Blätter, auf welche die Bakteriensuspension getropft wurde, verfärbten sich innerhalb von drei Wochen rötlich-gelblich und waren nach 6 Wochen ganz vertrocknet.

Tab. 20: Nachweis der markierten Bakterien $(X c p)$ im Blatt und Blattstiel nach oberflächlichem Auftropfen am 09. 08. 1998 (ausgedrückt in cfu pro 0,1 /ml Homogenat oder Waschflüssigkeit).

\begin{tabular}{lcclc}
\hline & \multicolumn{2}{c}{ Homogenat } & \multicolumn{2}{c}{ Waschflüssigkeit } \\
Datum & Blatt & Blattstiel & Blatt & Blattstiel \\
\hline 12. 10. 1998 & $8,5 \times 10^{5}$ & $4,5 \times 10^{5}$ & $3 \times 10^{4}$ & n. zählbar \\
24. 10. 1998 & $1,1 \times 10^{4}$ & $3 \times 10^{4}$ & n. gefunden & $1,5 \times 10^{4}$ \\
\hline
\end{tabular}

Die Waschflüssigkeit gibt die Konzentration der epiphytischen Bakterien wieder, das Homogenat enthielt im wesentlichen die in das Gewebe eingedrungenen Bakterien.

Aus den Ergebnissen geht hervor, dass die auf die Blattoberfläche aufgetropften Bakterien dort epiphytisch unter Gewächsbedingungen 2 bis 2,5 Monate überlebten. Innerhalb von 2 Monaten waren sie in das Blatt und den Blattstiel eingedrungen (Tab. 20). Später (nach 150 und nach 315 Tagen) wurden die Bakterien auch im Stengel, aber noch nicht in unbehandelten Blättern, nachgewiesen, ohne dass sich zunächst Symptome zeigten (Tab. 21).

Tab. 21: Nachweis der markierten Bakterien (Xcp) im Blatt und Stengel nach oberflächlichem Auftropfen am 09. 08. 1998 (ausgedrückt in cfu/g Frischstengel-Homogenat oder Waschflüssigkeit).

\begin{tabular}{c|l|l}
\hline Tag der Probenahme & Blatt & Stengel \\
\hline \hline 07. 01.1999 & n.gefunden & $2,8 \times 10^{3} \mathrm{cfu} / \mathrm{g}$ \\
07. 01. 1999 & n.gefunden & $3,2 \times 10^{3} \mathrm{cfu}$ \\
25. 06. 1999 & & $1,4 \times 10^{4} \mathrm{cfu} / \mathrm{g}$ \\
25. 06. 1999 & & $2,7 \times 10^{3} \mathrm{cfu} / \mathrm{g}$ \\
14. 01. 2000 & & n.gefunden \\
\hline
\end{tabular}




\subsection{2 Über die Wurzeln}

An den über die Wurzeln kontaminierten Pelargonienpflanzen (Methode bei 2.9.3) wurden fast 1 Jahr lang die Entstehung von Krankheitssymptomen und die Etablierung der Bakterien in den Wurzeln und im Stengel untersucht. Die Bildung von Symptomen blieb aus und die Bakterien konnten weder in den Wurzeln noch im Stengel der inokulierten Pflanzen nachgewiesen werden.

Den negativen Ergebnissen dieses Versuches steht entgegen, dass das Begießen einer Pelargonienpflanze mit $4 \mathrm{ml}$ Bakteriensuspension von $10^{8} \mathrm{cfu} / \mathrm{ml}$ innerhalb von 2 Monaten zu deutlichen Krankheitssymptomen und hohen Bakterienkonzentrationen in den Wurzeln führte (Kap. 3.7).

\subsection{3 Über die Schnittstelle}

Bis zum 02. 02. 1999 wurde wiederholt durch Isolation versucht, das Bakterium in den am 09. 08. 1998 inokulierten (Methode bei 2.9.2) und bis dahin symptomlos gebliebenen Pflanzen nachzuweisen, aber ohne Erfolg. Erst am 25. 06. 1999, d. h. nach 315 Tagen, wurden zum ersten Mal Xcp-Kolonien nachgewiesen (Tab. 22). Dies war nur möglich, weil der Test durch Einschaltung einer Zwischenvermehrung empfindlicher gemacht werden konnte. Bei der Zwischenvermehrung wurden die Scheibchen in einer TC-Lösung $24 \mathrm{~h}$ bei $28{ }^{\circ} \mathrm{C}$ kultiviert.

Tab. 22: Vorkommen von $X c p$ in Pelargonienpflanzen, deren Stecklinge am 09. 08. 1998 an der Schnittstelle mit $X c p$-Suspension betropft worden waren

\begin{tabular}{l|l}
\hline Tag der Probenahme & Befund \\
\hline \hline 01. 10. 1998 & Negativ \\
08. 12. 1998 & Negativ \\
07. 01. 1999 & Negativ \\
02. 02. 1999 & Negativ \\
25. 06. 1999 & Positiv \\
\hline
\end{tabular}

Dieser Versuch wurde wie in Kap. 3.5 beschrieben fortgeführt, indem aus den äußerlich gesunden Pflanzen neue Stecklinge gewonnen wurden. 


\subsubsection{Durch den Samen}

Mit Pelargonien wurden hier keine Versuche zum Vorkommen der Bakterien in den Samen durchgeführt. Es wurde jedoch festgestellt, dass bei der ebenfalls für $X c p$ anfälligen Art Geranium pusillum nach Inokulation über das Blatt oder den Stengel die Bakterien in der erkrankten Pflanzen im Samen vorkamen (Kap. 3.9). Da die Bakterien in unseren Versuchen häufig in Blütenknospen, Dolden und im Blütenstengel in Konzentrationen bis zu $10^{8}$ cfu/g nachgewiesen wurden (Abb. 10 und 14), ist sehr wahrscheinlich, dass die Bakterien auch die Samen von Pelargonien besiedeln können.

\subsection{Untersuchungen an aus latent infizierten Pflanzen gewonnenen Stecklingen}

Von 10 latent infizierten Pflanzen aus Versuch 3.4.3 wurden 18 Stecklinge gewonnen. Vor dem Einpflanzen wurde die Basis der Stecklinge auf Bakterienbefall untersucht (Methode siehe 2.9.4), und in 6 Proben wurden die Bakterien gefunden (Tab. 23).

Tab. 23: Nachweis der markierten Bakterien in der Basis von "Rosario“-Stecklingen am 25. 06. 1999 aus äußerlich gesunden Pflanzen, die am 09. 08. 1998 inokuliert worden waren.

\begin{tabular}{c|c|c}
\hline Proben Nr. & $\begin{array}{c}\text { Inokulumskonzentration } \\
\text { am 09. 08. 1998 }\end{array}$ & cfu/g im Stengel \\
\hline \hline 1 & $10^{3}$ & $3,3 \times 10^{3}$ \\
2 & $10^{3}$ & $8,0 \times 10^{3}$ \\
3 & $10^{3}$ & $2,5 \times 10^{3}$ \\
4 & $10^{3}$ & $5,0 \times 10^{3}$ \\
5 & $10^{4}$ & $1,7 \times 10^{3}$ \\
6 & $10^{4}$ & $1,1 \times 10^{4}$ \\
\hline
\end{tabular}

Die von den Stecklingen gewonnenen Tochterpflanzen wurden regelmäßig bonitiert und untersucht. Trotz vielfacher Isolationsversuche sowohl mit dem direkten Verfahren als auch nach einer Zwischenvermehrung konnte das eingesetzte Bakterium in den ersten 6 Monaten nicht nachgewiesen werden. Erst am 14. 01. 2000 wurden die ersten Krankheits- 
symptome bei der Variante mit dem niedrigen Inokulum (siehe 2.9.2) registriert, und das Bakterium konnte isoliert werden (Tab. 24). Von den übrigen Pflanzen zeigten einige nach 18 Monaten starke Welkesymptome und wiesen hohe Bakteriendichten auf.

Tab. 24: Nachweis von Bakterien in Pelargonien, deren Stecklinge aus latent infizierten Mutterpflanzen gewonnen wurden

\begin{tabular}{l|c|c}
\hline Tag der Probenahme & Versuchsvariante & Stengel \\
\hline \hline 09. 10. 1999 & $10^{3}$ Rosario & negativ \\
09. 10. 1999 & $10^{4}$ Rosario & negativ \\
14. 01. 2000 & $10^{3}$ Rosario & $2,1 \times 10^{8} \mathrm{cfu} / \mathrm{g}$ \\
\hline
\end{tabular}

\section{6 Übertragung von $X c p$ in der Erde}

Im Langzeitversuch nach Inokulation der Pelargonien am Stengel (Kap. 3.3) wurde wiederholt das Vorkommen der Bakterien in der Topferde untersucht. Die Ergebnisse sind exemplarisch in Abb. 10 und 14 wiedergegeben. So wurden bei einer Pelargonienpflanze der Sorte "Rosario“ 3 Monate nach Stengelinokulation bei $25{ }^{\circ} \mathrm{C}$ mit ca. 100 Bakterienzellen in 2 Bodenproben 2,3 x $10^{3}$ und $5 \times 10^{3}$ cfu/g nachgewiesen, und bei der Sorte "Isabell“ wurden unter gleichen Versuchsbedienungen, aber Inkubation bei $15^{\circ} \mathrm{C}$, sogar $1 \times 10^{5}$ cfu/g Erde gefunden (Abb. 14). Offenbar diffundierten die Bakterien von den erkrankten Pflanzen in die Erde. Dieser Befund wurde durch den Nachweis der Bakterien im Sickerwasser, das nach übermäßigen Wässern im Auslass der Blumentöpfe aufgefangen wurde, bestätigt. Im Sickerwasser wurden bis zu 2 x $10^{4} \mathrm{cfu} / \mathrm{ml}$ gefunden (Tab. 26).

In den hier durchgeführten Versuchen fand eine Infektion der Pelargonienpflanzen durch die im Stauwasser vorkommenden Bakterien bei allen drei Konzentrationen $\left(10^{9}, 10^{7}\right.$ und $10^{4} \mathrm{cfu} / \mathrm{ml}$ ) über die Erde nicht statt. Nach knapp 9 Monaten konnten Xcp-Zellen weder in der Erde noch in den Wurzeln oder im Stengel nachgewiesen werden. Wenn das bakterienkontaminierte Wasser von unten durch die Blumentöpfe aufgenommen wurde, konnten die Bakterien in diesem Versuch die Pelargonien nicht infizieren. Andererseits wurde durch ein Begießen der Töpfe mit Bakteriensuspension $\left(10^{8} \mathrm{cfu} / \mathrm{ml}\right)$ innerhalb kurzer Zeit die Krankheit ausgelöst (Kap. 3.7). 
Die Möglichkeit, dass die Bakterien über das Bodenwasser zu Nachbarpflanzen übertragen werden, kann deswegen nicht ausgeschlossen werden. Der hierzu angelegte Versuch (Methode in Kap. 2.9.5) lässt diese Möglichkeit offen, da das Begießen einer Pelargonienpflanze mit $4 \mathrm{ml}$ Bakteriensuspension von $10^{8} \mathrm{cfu} / \mathrm{ml}$ innerhalb von 2 Monaten zu starken Krankheitssymptomen führte (Kap. 3.7).

\section{7 Übertragung durch Gießwasser}

Der Versuchsaufbau ist im Kapitel 2.9.5, Gießwasser, beschrieben. Von den 5 untersuchten Pelargonienpflanzen zeigte nur die mit $4 \mathrm{ml}$ Inokulum $\left(10^{8} \mathrm{cfu} / \mathrm{ml}\right)$ begossene Pflanze innerhalb von 2 Monaten typische Krankheitssymptome. Die Ausbreitung der Bakterien in dieser Pflanze wurde durch Isolationen aus den verschiedenen Teilen untersucht. Der ganze Stengel wurde von seiner Basis ausgehend mit 1, 2, 3, 4 und 5 numeriert und ebenso wie Erde und Wurzeln untersucht. Durch das Begießen mit bakterien-kontaminiertem Wasser erkrankte die ganze Pflanze innerhalb von 2 Monaten. Die Bakterien hatten die Pflanze systemisch befallen (Tab. 25) und wurden in der höchsten Konzentration (>10 $\mathrm{cfu} / \mathrm{g})$ in den Wurzeln und an der Stengelbasis gefunden. Aber auch in der Triebspitze wurden noch $2 \times 10^{6} \mathrm{cfu} / \mathrm{g}$ Bakterien nachgewiesen.

Die Nachbarpflanzen zeigten im Versuchszeitraum keine Symptome, und in der mikrobiologischen Untersuchung am 31. 03. 2000 wurden ebenfalls keine Xcp-Kolonien gefunden.

Tab. 25: Überprüfung der Infektion von Pelargonienpflanzen durch $X c p$ über das Gießwasser (Inokulationstag: 22. 08. 1999; Tag der Auswertung: 24. 10. 1999)

\begin{tabular}{|c|c|c|c|c|}
\hline \multicolumn{2}{|c|}{ Bakteriendichte in der Topferde } & \multicolumn{2}{|c|}{ Bakteriendichte im Stengel } & \multirow{2}{*}{$\begin{array}{l}\text { Bakteriendichte in } \\
\text { den Wurzeln (cfu/g) }\end{array}$} \\
\hline Erde & $\mathrm{cfu} / \mathrm{g}$ & Stengelabschnitt & $\mathrm{cfu} / \mathrm{g}$ & \\
\hline Oben & $5 \times 10^{2}$ & $1^{\mathrm{X})}$ & $1,4 \times 10^{8}$ & $>10^{8}$ \\
\hline Mitte & $3,2 \times 10^{3}$ & 2 & $1,2 \times 10^{8}$ & \\
\hline \multirow[t]{3}{*}{ Unten } & $2 \times 10^{3}$ & 3 & $1 \times 10^{7}$ & \\
\hline & & 4 & $3,2 \times 10^{6}$ & \\
\hline & & 5 & $2 \times 10^{6}$ & \\
\hline
\end{tabular}

x) 1 = Stengelbasis, 5 = Triebspitze 


\subsection{Vorkommen der Bakterien im Sickerwasser von Pelargonien}

Wenn infizierte Pelargonienpflanzen stark gegossen und das durch die Blumentöpfe hindurchlaufende Wasser aufgefangen wurde, konnten in diesem "Sickerwasser" beachtliche Bakterienmengen nachgewiesen werden (Tab. 26). Dies war schon 3 Monate nach Inokulation mit einem Inokulum vor ca. 2 x $10^{3}$ Bakterienzellen pro Pflanze der Fall. Bei der weniger anfälligen Sorte "Isabell“" wurden auch deutlich weniger Bakterien im Sickerwasser gefunden.

Tab. 26: Vorkommen der Bakterien im Sickerwasser von Pelargonienpflanzen, die am 08. 01. 1996 mit den angegebenen Konzentrationen von Xcp im Stengel inokuliert worden waren.

\begin{tabular}{c|c|c}
\hline Tag der Probenahme & Versuchsvariante & cfu/ml \\
\hline \hline 5. 4. 1996 & $10^{3}$ Rosario & $2,0 \times 10^{3}$ \\
5. 4. 1996 & $10^{3}$ Isabell & $2,0 \times 10^{1}$ \\
5. 4. 1996 & $10^{4}$ Rosario & $2,1 \times 10^{4}$ \\
3. 7. 1996 & $10^{5}$ Rosario & $2,7 \times 10^{3}$ \\
11. 11. 1999 & $10^{4}$ Rosario & $2,4 \times 10^{3}$ \\
\hline
\end{tabular}

\subsection{Anfälligkeit anderer Arten der Familie Geraniaceae für Xcp}

Durch diesen Versuch sollte überprüft werden, ob in der Praxis eine Infektion von den Pelargonien nahe verwandten Pflanzenarten ausgehen kann. Deshalb wurden Pflanzen von Erodium cicutorium, Geranium dissectum und Geranium pusillum mit der Xcp-Mutante (GSPB Nr. 2503) am 09. 06. 1996 inokuliert (Methode bei 2.10.1). Innerhalb von 12 Tagen zeigten die Pflanzen starke Symptome am Stengel und an den Blättern, und Xcp erreichte in den Stengeln hohe Konzentrationen (Tab. 27).

Tab. 27: Vermehrung von $X c p$ im Stengel verwandter Unkräuter 12 Tage nach künstlicher Infektion im Gewächshaus (cfu/ml Stengel Frischgewicht)

\begin{tabular}{l|l}
\hline Pflanzenart & Bakterienkonzentration \\
\hline \hline Erodium cicutorium & $>10^{8}$ \\
Geranium dissectum & $>10^{8}$ \\
Geranium pusillum & $>10^{8}$ \\
\hline
\end{tabular}


Bei Geranium pusillum wurde eine deutliche Welke verursacht, die Blätter blieben klein, vertrockneten schnell und fielen anschließend ab. Das Bakterium konnte in den Samen nachgewiesen werden. Erodium cicutorium zeigte braune Flecken am Stengel und an den Blättern, während bei Geranium dissectumm der Stengel Risse, vor allem an den Inokulationsstellen, aufwies und die Blätter normal aussahen. 


\section{DISKUSSION}

Der bakterielle Erreger der Stengelfäule und Blattfleckenkrankheit an Pelargonien, Xanthomonas campestris pv. pelargonii, wurde bereits 1898 von STONE und SMITH detektiert und 1923 von BROWN detailliert beschrieben. Trotzdem ist das Bakterium auch heute noch einer der häufigsten und gefährlichsten Krankheitserreger dieser Kulturpflanze. Eine der Ursachen für das Misslingen einer erfolgreichen Eliminierung des Bakteriums aus dem Zuchtmaterial ist die Fähigkeit des Pathogens, in seiner Wirtspflanze latent zu existieren, d. h. es gelingt ihm, in geringen Populationen ohne sichtbare Symptome über längere Zeiten in den Pelargonien präsent zu sein. Die Bedingungen, die zu einem langen, latenten Überleben der Bakterien in Pelargonien führen, wurden bisher noch nicht aufgeklärt. So weisen NAMETH et al. (1999) darauf hin, dass noch zu wenig darüber bekannt ist, wie die Bakterien während latenter Infektion in den Pelargonien verteilt sind, und unter welchen Umweltbedienungen sich die Bakterien in symptomlosen Pelargonien vermehren und ausbreiten.

Das Ziel der vorliegenden Arbeit war deswegen, weitere Erkenntnisse über das Zustandekommen der Latenz zu gewinnen. In dem dafür durchgeführten Langzeitversuch mussten auch noch sehr geringe Bakterienmengen im befallenen Gewebe nachweisbar sein. Deswegen wurde mit einer Rifampicin-resistenten Selektante von Xcp gearbeitet.

\subsection{Verwendung eines Rifampicin-resistenten $X c p$-Stammes}

Um die Ausbreitung phytopathogener Bakterien in der Natur leichter verfolgen zu können, werden häufig Antibiotika-resistente Stämme eingesetzt. Inzwischen hat sich wegen des häufigen natürlichen Vorkommens von Streptomycin-resistenten phytopathogenen Bakterien die Verwendung von Rifampicin-resistenten Stämmen durchgesetzt (CAFATI \& SAETTLER, 1980; LINDOW et al., 1988; HIRANO \& UPPER, 1993; MILUS \& MIRLOHI, 1993). Auch WÖLK und SARKAR (1994) benutzten eine Xcp-Mutante mit Resistenz gegen 120 ppm Rifampicin zum Nachweis des Bakteriums im Boden.

Durch die Hemmung der RNA-Synthese besitzt Rifampicin ein weites antibakterielles Spektrum und wird deswegen in epidemiologischen Untersuchungen immer häufiger eingesetzt (WELLER \& SAETTLER, 1978; ROTT et al., 1994). 
Für die vorliegenden Untersuchungen wurde zunächst eine Spontanmutante von $X c p$ gewonnen, die resistent gegen 100 ppm Rifampicin war. Zusätzlich zur Rifampicinresistenz wurde eine zweite Resistenz gegen 150 ppm Streptomycin selektiert. Diese Doppelmutante zeigte jedoch ein verlangsamtes und uneinheitliches Wachstum und wurde deshalb bei den Hauptuntersuchungen nicht eingesetzt.

Vor dem großen Einsatz für die Pflanzeninokulationen wurde der Rifampicin-resistente Stamm Xcp-2503 auf Virulenz überprüft. Dabei ergab sich, dass der markierte Stamm noch die gleiche Virulenz wie der Wildstamm besaß, d. h. Welke und Stengelfäule wurden in gleichem Ausmaß hervorgerufen. Auch eine Rückmutation der Mutante zum sensitiven Wildstamm wurde nach längerer Bakterienvermehrung in planta nicht festgestellt und die Resistenz als stabil betrachtet.

\subsection{Einfluss der Kulturtemperatur auf das Verhalten von Xanthomonas campestris pv. pelargonii in der Pflanze}

Fast alle Xanthomonas campestris-Pathovaritäten verursachen stärkere Krankheitssymptome in tropischen und subtropischen als in gemäßigten Regionen (RUDOLPH, 1993). Die optimale Temperaturspanne für Xcp liegt bei 27 - $30^{\circ} \mathrm{C}$, das Wachstumsmaximum bei $35{ }^{\circ} \mathrm{C}$ (MUNNECKE, 1954; BRADBURY, 1986). BROWN stellte schon 1923 fest, dass sich auf Pelargonium-Blättern innerhalb von 4 Tagen nach Inokulation typische Blattflecken entwickelten, wenn die Pflanzen bei $27{ }^{\circ} \mathrm{C}$ gehalten wurden. Wenn dagegen die Pflanzen bei 12 - $15{ }^{\circ} \mathrm{C}$ gehalten wurden, traten nur sehr geringfügige Krankheitssymptome auf. Auch KIVILAAN und SCHEFFER (1958) fanden, dass die Krankheit durch hohe Temperaturen $\left(21-27^{\circ} \mathrm{C}\right)$ gefördert und durch niedrige $\left(10^{\circ} \mathrm{C}\right)$ verlangsamt wurde. BUGBEE und ANDERSON (1963) beobachteten, dass sich die Blattpusteln ("Blisters“) bei niedrigen Temperaturen $\left(18-21^{\circ} \mathrm{C}\right)$ in 4 Monaten nicht veränderten oder vergrößerten, während sie sich weiterentwickelten, wenn die Pflanzen zu einer höheren Temperatur transferiert wurden. Auch andere Autoren fanden, dass Temperaturen zwischen $25{ }^{\circ} \mathrm{C}$ und $30{ }^{\circ} \mathrm{C}$ den Krankheitsverlauf beschleunigten, während Temperaturen unter $15{ }^{\circ} \mathrm{C}$ eine hemmende Wirkung ausübten (HENSELER, 1970; SAUTHOFF, 1975; MILLER et al., 1978). Symptome der Xanthomonas-Welke traten bei $10{ }^{\circ} \mathrm{C}$ erst nach 6 - 8 Wochen und dann auch nur bei einem Teil der Pflanzen auf (SAUTHOFF, 1974). Unterhalb von $4{ }^{\circ} \mathrm{C}$ und oberhalb von $35^{\circ} \mathrm{C}$ wachsen die Xcp-Zellen nicht (SWINGS und CIVEROLO, 1993). 
In den vorliegenden Untersuchungen wurde der Einfluss der Temperatur auf die Vermehrung und die systemische Ausbreitung des Erregers in Pelargonienpflanzen in einem Langzeitversuch von 68 Monaten überprüft, wie er unseres Wissens bisher noch nie durchgeführt wurde. Im Verlaufe des ersten Jahres verlief der Befall der Pelargonienpflanzen bei der $15{ }^{\circ} \mathrm{C}$ Variante erwartungsgemäß langsamer als bei der $25{ }^{\circ} \mathrm{C}$ Variante. Besonders deutlich war dieser Unterschied bei den niedrigen Inokulumskonzentrationen von $10^{4}$ und $10^{3} \mathrm{cfu} / \mathrm{ml}$. Bei $15^{\circ} \mathrm{C}$ erfolgte die Erkrankung zwar langsamer, aber kontinuierlicher, so dass am Ende des Versuches (nach 68 Monaten) von den bei $15{ }^{\circ} \mathbf{C}$ gehaltenen Pflanzen deutlich mehr erkrankt waren. Bei den wärmer gehaltenen Pflanzen starben die inokulierten Bakterien in denjenigen Pflanzen, in denen sie nicht innerhalb von 11 Monaten eine Erkrankung ausgelöst hatten, ganz ab.

Als Ursache für das Absterben der Bakterien werden starke Temperaturschwankungen im Sommer angenommen. So wurde festgestellt, dass in der wärmeren Gewächshauskabine die Temperatur im Sommer der Jahre 1998, 1999 und 2000 extrem hohe Werte erreichte. Dies führte offenbar dazu, dass geringe Bakterienkonzentrationen im Stengel stark reduziert oder die Bakterien sämtlich abgetötet wurden, so dass nur wenige oder gar keine Pflanzen später starken Befall zeigten.

In der kühleren Kabine war die Temperaturregulation wesentlich besser, obwohl auch hier eine geringe Temperaturerhöhung im Sommer stattfand. Die wenigen noch lebenden Bakterien konnten sich dann in der Endphase, auch begünstigt durch das starke Wachstum der Pelargonien nach der intensiveren Düngung, stark vermehren und von der bis dahin latenten in die aktive und virulente Phase übergehen.

Aus diesen Versuchsergebnissen ergab sich als eine Empfehlung für die erfolgreiche Eliminierung latent befallener Pelargonienpflanzen, dass Mutterpflanzen für die Stecklingsgewinnung für einen bestimmten Zeitraum (6 - 9 Monate) bei relativ hoher Temperatur (z. B. $25{ }^{\circ} \mathrm{C}$ ) gehalten und gleichzeitig gut gedüngt werden sollten, da dann latent in der Pflanze vorkommende Bakterien die Krankheit auslösen können und eine Elimination dieser Pflanzen möglich ist. Auch NAMETH et al. (1999) weisen auf die große Gefahr hin, dass Xcp besonders dann die Pflanzen latent besiedelt, wenn sie bei niedrigen Temperaturen gehalten werden.

Die Versuche mit Temperaturwechsel nach 6 Monaten (d. h. von 15 nach $25{ }^{\circ} \mathrm{C}$ oder umgekehrt) bestätigten die bei konstanten Temperaturen gewonnenen Erkenntnisse (siehe Kapitel 3.3.7.3b). Auch hier wurde mit allen drei Inokulumskonzentrationen $\left(10^{5}, 10^{4}\right.$ und $10^{3} \mathrm{cfu} / \mathrm{ml}$ ) in der Endphase der Versuche eine deutliche Erhöhung der Befallsrate 
cfu/ml) in der Endphase der Versuche eine deutliche Erhöhung der Befallsrate festgestellt, wenn die Pflanzen nach der Temperaturumstellung bei $15{ }^{\circ} \mathrm{C}$ statt $25^{\circ} \mathrm{C}$ gehalten wurden.

\subsection{Charakterisierung der Latenz}

Durch den hier durchgeführten Langzeitversuch mit einem markierten Bakterienstamm wurde u. W. erstmalig belegt, wie lange die Bakterien sich im latenten Stadium ohne Auslösung von Krankheitssymptomen in der Pflanze aufhalten können. In diesen Versuchen wurde eine maximale Latenzperiode von 57 Monaten festgestellt, bei Pelargonien der Sorte "Rosario“, die nach Inokulation mit $10^{1} \mathrm{cfu} / \mathrm{ml}$ in den Stengel bei $15{ }^{\circ} \mathrm{C}$ gehalten wurden (Tabelle 17).

Die Bakterien vermehrten sich nach der Inokulation im Stengel nur wenig. In der weitaus überwiegenden Zahl der Fälle (76\%) schwankte die Bakterienkonzentration im Stengel während der Latenzphase zwischen $\mathbf{1 0}^{2}-\mathbf{1 0}^{3}$ cfu/g Stengelfrischgewicht (Tabelle 18). In den meisten Fällen befanden sich die Bakterien nur nahe der Inokulationsstelle in niedriger Konzentration. Wahrscheinlich lagen sie dort eingekapselt. Offenbar hatte sich ein Gleichgewicht zwischen bakteriellem Wachstum und pflanzlichen Abwehrreaktionen, wie z. B. der Phytoalexinproduktion, eingestellt (RUISSEN et al., 1993). Als Hauptursachen im Zusammenwirken verschiedener latenzbestimmender Faktoren wurden von BERKELMANN et al. (1994) die Saison, der Entwicklungszustand der Pflanze und deren physiologische Konstitution genannt.

Ähnlich wie während der frühen Infektionsphase von Xanthomonaden (RUDOLPH, 1993) kommen die Bakterien wahrscheinlich während der Latenzphase in Mikrokolonien im Gewebe vor. In den Mikrokolonien sind die Bakterienzellen in extrazelluläre Polysaccharide (Xanthan und Lipopolysacharide) eingeschlossen oder eingekapselt und dadurch vor Austrocknung oder vor pflanzlichen Abwehrstoffen, wie den Phytoalexinen, geschützt (RUDOLPH, 1993).

Unsere Versuche zeigten, dass die Bakterien inhomogen im Stengel verteilt waren; denn in den Nodien war die Bakterienkonzentration immer höher als in den Internodien (Abb. 15). Eine weitere Charakterisierung der bakteriellen Mikrokolonien oder "Bakterientaschen" könnte deswegen durch eine histologische Untersuchung der Nodien erfolgen. Die geringen Bakterienpopulationen während des latenten Befalls sind in planta jedoch sehr schwer histologisch nachweisbar. Durch die inhomogene Verteilung der Bakterien in der Pflanze und saisonale Schwankungen in der Pathogendichte ist es generell sehr schwierig, die Bak- 
terien bei der Pathogen-Diagnose überhaupt nachzuweisen. Wenn das Gleichgewicht der verschiedenen Faktoren, die die Latenz bedingen, gestört wird, kann es dazu kommen, dass entweder die Bakterien ganz absterben und die Pflanze gesundet, oder dass von den Bakterien die Latenzphase durchbrochen wird und die Krankheit ausbricht.

\subsection{Faktoren, welche die Latenz beeinflussen}

Der entscheidende Faktor nach den hier beschriebenen Versuchen war die Temperatur während der Pelargonienkultur (Kapitel 4.2). Niedrige Temperaturen $\left(15^{\circ} \mathrm{C}\right)$ führten zu einer langen Latenz, höhere Temperaturen $\left(25^{\circ} \mathrm{C}\right) \mathrm{zu}$ einer wesentlich kürzeren Latenzphase, und extrem hohe Temperaturen zur Abtötung der Bakterien.

Auch die Nährstoffversorgung der Pflanze beeinflusst die Latenz. Die Anfälligkeit der Pflanzen gegenüber $X c p$ wird durch erhöhte Stickstoffgaben gesteigert (DIGAT, 1977; SAUTHOFF, 1978). Dagegen fördert eine Kali-betonte Düngung die pflanzlichen Abwehrkräfte (HEIMANN, 1973; GIBONI, 1985). Auch KREBS et al. (1993) konnten bei Pelargonien nachweisen, dass bei niedrigem Befallsdruck von Xcp eine N-Unterversorgung den Krankheitsverlauf verzögerte. In den hier beschriebenen Versuchen wurden ab August 1998 die Pflanzen wöchentlich mit 1\% Hakaphos gedüngt. Durch diese regelmäßige, intensive Düngung durchbrachen die Bakterien die Latenzphase offenbar schneller als bei geringer Düngung.

Wenn das Wachstum der Pelargonien nicht durch Düngung sondern durch Anreicherung der $\mathbf{C O}_{2}$-Konzentration gefördert wurde, wurde ebenfalls eine Erhöhung der Krankheit festgestellt (JIAO et al., 1999).

COOKE et al. (1992) beschrieben den pH-Wert im Boden als einen wichtigen Faktor für die Latenzerscheinung bei Bakterieninfektionen. Lag dieser unter 4,5, wurde das Wachstum u. a. von Xanthomonas campestris pv. pelargonii unterdrückt. Ein deutlicher Einfluss der Pelargonien-Sorte auf die Dauer der Latenz konnte in den hier durchgeführten Versuchen mit nur 2 Sorten nicht festgestellt werden (Tab. 17), ist aber anzunehmen.

Wenn immer durch Förderung der Bakterien eine bestimmte Bakterienkonzentration in planta überschritten wird, kommt es zum Durchbrechen der Latenz. Die dafür notwendige Schwelle der Bakterienkonzentration lag in unseren Versuchen bei etwa $\mathbf{1 0}^{\mathbf{6}} \mathbf{~ c f u / g}$ Frischgewicht. Aber erst ab $10^{8} \mathrm{cfu} / \mathrm{g}$ entwickelten sich starke Symptome, und es kam zu einer systemischen Ausbreitung der Bakterien im Gewebe. 


\subsection{Systemische Ausbreitung der Bakterien in Pelargonienpflanzen}

Wenn die Latenz einmal durchbrochen war, breiteten die Bakterien sich vom Inokulationspunkt im Stengel akropetal und basipetal systemisch in der ganzen Pflanze aus. Bei "Rosario“ wurden die Bakterien z. B. 3 Monate nach Inokulation bereits überall im Stengel, in der Dolde, den Blütenknospen, Blattstielen, Blättern, Wurzeln und sogar in der Erde und im Sickerwasser nachgewiesen (Abb. 10). Auch andere Autoren beschrieben den systemischen Charakter der Krankheit. Schon MUNNECKE (1954) wies auf die systemische Ausbreitung des Pathogens, ausgehend von Blattflecken, über die ganze Pflanze hin. Ebenso zeigten DOUGHERTY et al. (1974), dass eine systemische Verbreitung des Erregers von Blattflecken aus über die Blattstiele bis in den Stengel erfolgte, wo vollständige Welkeund Fäulniserscheinungen hervorgerufen wurden. Auch BRÖTHER (1981 b) konnte nach künstlicher Stengelinokulation aus Stengelteilen und Blättern über und unter der Infektionsstelle Bakterien reisolieren.

Die Besiedlung der Pelargonienwurzeln durch $X c p$, vom Stengel ausgehend, wurde bisher nicht beschrieben, ist aber von anderen Xanthomonaden bekannt, wie $X$. oryzae pv. oryzae (ZARAGOZA and MEW, 1979) oder X. c. pv. graminis (LEYNS et al., 1988). Auf infizierte Wurzeln, die sich im Verlaufe der Erkrankung teilweise zersetzen, ist wahrscheinlich auch das von uns festgestellte Vorkommen der Bakterien im Boden und im Sickerwasser zurückzuführen.

Die in dem hier beschriebenen Langzeitversuch bestimmten Bakterienkonzentrationen in planta wurden in dieser Ausführlichkeit bisher noch nie erfasst (z. B. Abb. 10, Abb. 14, Tabelle 19). Beeindruckend sind die hohen Bakterienkonzentrationen in stark befallenen Stengeln, wie $8.3 \times 10^{10} \mathrm{cfu} / \mathrm{g}$ Stengelfrischgewicht bei "Rosario“ und 9,5 x $10^{9} \mathrm{cfu} / \mathrm{g}$ bei "Isabell“. In alten Pflanzen am Ende des Langzeitversuches waren trotz starker Symptome die maximalen Bakterienkonzentrationen im Stengel deutlich niedriger (Tabelle 19). Wahrscheinlich war die Anfälligkeit durch die zunehmende Verholzung und Anreicherung sekundärer Pflanzenmetabolite etwas reduziert.

Um weitere Einblicke in das Vorkommen der Bakterien im Stengel zu gewinnen, wurden in mehreren Fällen Nodien und Internodien getrennt untersucht. Dabei ergab sich, dass in latent befallenen Pelargonien die Nodien meistens 10-fach mehr Bakterien enthielten als die Internodien. Weitere Versuche zur histologischen Charakterisierung der bakteriellen Mikrokolonien bei Latenz sollten deswegen mit den Nodien durchgeführt werden. 


\subsection{Symptome}

Im Verlaufe der systemischen Besiedlung der Pelargonien entwickelten sich bald die typischen Krankheitssymptome. Am auffälligsten waren die Blattsymptome mit verschiedenen Formen der Welke (Schirmwelke). Anfänglich welkten nur einzelne Blattbereiche, später wurde der gesamte Blattrand schlaff. Das Blatt ähnelte in seiner Form einem Regenschirm. Schirmwelken traten grundsätzlich an Orten mit massiver Bakterienvermehrung auf. Auch DIGAT (1977), BRÖTHER (1979) und KREBS (1992) beschrieben die vom Blattrand ausgehenden, sektorenförmigen Vergilbungen, die sich später bräunlich verfärbten und vertrockneten. Als Begleitsymptome der Blattflecken traten manchmal an der Blattunterseite kleine, wässrige Pusteln, als „Ödeme“ bezeichnet auf, die später aufplatzten und verkorkten. BUGBEE \& ANDERSON (1963) halten diese Korkflecken für ein von Xcp verursachtes Symptom, die ein Anzeichen für den Beginn einer bakteriellen Blattinfektion sein können. HEIMANN (1973) gelang es, aus jungen Pusteln pathogene ХcpStämme zu isolieren. Er schloss daraus, dass die Symptome dieser Korkfleckenkrankheit bis zu einem gewissen Grad mit der Bakteriose zusammenhängen.

Die Stengelfäule oder Trockenfäule kann von der Basis des Stengels wie auch von oberen Stengelteilen ausgehen. Es bildeten sich zuerst glasige, grünliche Stellen, die in trockene, schwarze Läsionen übergingen. Benachbarte Sprosse und Blätter schrumpften und verdorrten. Aus den Faulstellen kann Bakterienschleim austreten (siehe auch: HEIMANN, 1973; BURKI, 1972; GIBONI, 1985). Eine ausführliche Beschreibung der gesamten Krankheitssymptome lieferten schon früh HELLMERS (1952) und MUNNECKE (1954). Histologische Untersuchungen von WAINWRIGHT und NELSON (1973) zeigten, dass Xcp ein typischer Xylembesiedler ist. Zunächst besiedeln die Bakterien die Pflanzen durch das Xylem systemisch und dringen dann lateral in das benachbarte Parenchymgewebe ein. Dann kommt es zur Ausprägung der sogenannten Bakterientaschen um die befallenen Protoxylemgefäße herum, welche sich vergrößern und schließlich Teile des Kambiums, Phloems, der Cortex und Epidermis umfassen. Die Bakterienmassen zusammen mit bakteriellem Schleim (Xanthan und Lipopolysaccharide) und zersetztem pflanzlichen Gewebe verschließen das Gefäßsystem und lösen die Pelargonienwelke aus. 


\subsection{Sortenvergleich}

Resistenz gegenüber $X c p$ wurde bei verschiedenen Wildarten gefunden (PAGEL 1993; OLBRICHT und GRIESBACH, 2002). Von KNAUSS und TAMMEN (1967) wurde P. x domesticum als hochresistent eingestuft, $P$. graveolens als mäßig resistent und die Hängepelargonie $P$. peltatum als sehr anfällig. Aber auch in Wurzel-inokulierten Pflanzen von $P$. x domesticum blieb das Pathogen 66 Tage aktiv, so dass diese Pelargonienart nicht mehr als immun eingestuft werden kann. In den resistenten Pelargonium-Arten kann sich das Bakterium nicht so stark vermehren (NELSON und WAINWRIGHT, 1973). Die Resistenz könnte in der Struktur der pflanzlichen Zellwände begründet sein. WAINWRIGHT \& NELSON (1973) erwähnen das Fehlen von Zellulosewänden und Pektinverbindungen in den Bakterientaschen anfälliger Pelargonien, was ein Zeichen für die Auflösung von Wirtszellwänden während der Pathogenese bei nicht-resistenten Pelargoniumarten ist.

Bei den heute auf dem Markt verbreiteten Kultur-Hybriden ist keinerlei Resistenz festzustellen (BACHTHALLER und KREBS, 1987).

Frühere Versuche zur Resistenzzüchtung bei P. x hortorum waren erfolglos (NELSON und WAINWRIGHT, 1973), da zwar signifikante Resistenz bei verschiedenen PelargoniumArten vorkommt, jedoch bei Sorten der sehr bedeutenden Hybride P. X hortorum fehlt. Nachteilig wirkt sich dabei auch aus, dass sich die Elterntypen dieser Hybride ( $P$. zonale (L.) L `Her ex Ait., P. inquinans (L) L`Her ex Ait., und P. scanders (Ehrh.)) als hoch anfällig erwiesen (KNAUSS und TAMMEN, 1967).

In den vorliegenden Untersuchungen wurde im Vergleich der beiden Pelargonien-Sorten eine deutlich niedrigere Anfälligkeit bei "Isabell“ festgestellt. Dies zeigte sich vor allem in einem schnelleren Verlauf der Erkrankung bei "Rosario“ und darin, dass mehr Versuchspflanzen von "Rosario" als von "Isabell" erkrankten. Außerdem waren die maximalen Bakterienpopulationen in "Rosario" 10-fach höher als in "Isabell". Dieser Befund stimmte mit den Beobachtungen der Züchter überein, wonach "Rosario“ anfälliger gegenüber $X c p$ ist. Die etwas geringere Anfälligkeit von "Isabell“ reicht jedoch für eine wirksame Unterdrückung der Krankheit bei weitem nicht aus. Die höhere Anfälligkeit von "Rosario“ zeigte sich in unseren Versuchen schon wenige Monate nach Inokulation der Stengel mit $10 \mu \mathrm{l}$ 
einer Bakteriensuspension von $10^{4} \mathrm{cfu} / \mathrm{ml}$. Wenn genügend Gewächshausplatz zur Verfügung steht, könnte dies ein einfacher Resistenztest sein.

\subsection{Infektions-und Übertragungswege}

Die häufigste Übertragung des Bakteriums von einer Saison zur nächsten passiert nach MUNNECKE (1954) durch symptomlose Pflanzen, welche die Bakterien latent beherbergen. Die Krankheitsübertragung durch Stecklinge dieser Mutterpflanzen ist damit der wichtigste Übertragungsweg.

Da die Bakterien nicht fähig sind, über die intakte Epidermis in die Pflanze einzudringen, sind sie auf Wunden, nicht-kutinisierte Stellen wie z. B. Wurzelhaare oder natürliche Öffnungen, wie Stomata und Hydathoden, angewiesen (RUDOLPH, 1993). Die Infektion der Pelargonien erfolgt daher über Spaltöffnungen der Blätter, Wunden an Blättern und Stengeln oder verletzte Wurzeln. Besonders gefährlich sind die beim Stecklingsschnitt oder durch Entfernen von Blüten und Blätter entstehenden offenen Wunden (BRÖTHER, 1979). Bei histologischen Untersuchungen von Pelargonium zeigte sich, dass eine Invasion der Bakterien nur über natürliche Öffnungen (Stomata, Interzellulare) oder verletztes Gewebe erfolgt (HAMACHER et al., 1996; KURZE, 1997).

\subsubsection{Infektion über das Blatt}

Von einigen pflanzenpathogenen Bakterien ist schon seit langen bekannt, dass sie auch auf gesunden Pflanzenoberflächen längere Zeit überleben (CROSSE, 1959). Auch LEBEN (1970) beschrieb bei pflanzenpathogenen Bakterien die Fähigkeit zum epiphytischen Wachstum. Dort stellen sie das Inokulum dar, das bei günstigen Bedingungen zur Infektion führen kann (HIRANO und UPPER, 1983). Epiphytische Populationen wurden inzwischen bei vielen Pseudomonas-, Xanthomonas-, und Erwinia- Arten (BLAKEMAN 1993) sowie Clavibacter (GLEASON et al., 1991) beobachtet. HATTINGH et al. (1989) berichteten über epiphytisch vorkommende Populationen von Pseudomonas syringae an Obstbäumen, welche zu einer systemischen Infektion durch natürliche Öffnungen führten. Die Bakterien vermehrten sich dort zunächst symptomlos auf der Blattoberfläche und drangen dann durch die Stomata über die Parenchymzellen in das Gefäßsystem der Pflanze ein. Es ist schon lange bekannt, dass die Bakterien, vor allem die phytopathogenen an Obstbäumen, durch Blattnarben, Blattverletzungen (CROSSE et al., 1972) und Blattstiele (GOODMAN und 
WHITE, 1981) in die Xylemgefäße gelangen und sich in diesen Gefäßen systemisch ausbreiten können.

DIGAT (1978a) wies in diesem Zusammenhang auf eine erhebliche Gefährdung durch epiphytische $X c p$-Populationen hin, die sich für mindestens 2 Monate auf Blattoberflächen aufhielten, bevor Krankheitssymptome auftraten. Diese Epiphyten stellen ein ständiges Infektionspotenzial dar; bei günstigen Bedingungen können sie in die Blätter eindringen. Sie werden über Spritzwasser bei der Bewässerung verbreitet. Nach MILLER et al. (1978) kann sich Xcp über das Blatt durch den Blattstiel ausbreiten und am Stengel eine dunkelbraune bis schwarze Stengelfäule verursachen.

KIVILAAN und SCHEFFER (1958) vermuteten, dass das Pathogen von Blattflecken aus nicht systemisch werden könne. Dagegen stellte MUNNECKE (1954) fest, dass eine Ausbreitung des Erregers von Blattflecken ausgehend über die Blattstiele auf die ganze Pflanze stattfand.

Zur Quantifizierung epiphytischer Bakterienpopulation auf Pflanzen werden meist Verdünnungsreihen auf Agarplatten mit Antibiotika ausplattiert. Bei der Wasch-HomogenatMethode werden die Blätter 5 - 7 min (O’BRIEN \& LINDOW, 1989) oder 60 - 120 min (HIRANO et al., 1983) in Waschpuffer kräftig geschüttelt und dann im Puffer homogenisiert (LEBEN et al., 1968; CAFATI \& SAETTLER, 1980). VON KIETZELL (1995) berichtete, dass Pseudomonas syringae pv. atrofaciens relativ fest an den Blättern hafteten und erst nach 8 h Waschdauer übertraten. Bei dieser häufig verwendeten Methode sind jedoch keine Rückschlüsse auf die Lokalisation der Bakterien möglich. Die Bakterien können nach längerem Waschen von den Oberflächen, aus den substomatären Visikeln oder sogar aus dem Interzellularraum stammen. Nach kurzer Waschdauer wird jedoch nur ein kleiner Teil der Epiphyten erfasst.

Deswegen wurden in den vorliegenden Untersuchungen Pelargonienblätter 10 - 15 min geschüttelt, um die Kontaminantenzahlen zu reduzieren, und dann in frischer Lösung homogenisiert. Die Bakteriendichten im Waschwasser und Homogenat wurden getrennt bestimmt. Dabei wurde festgestellt, dass die Bakterien epiphytisch auf dem Blatt 2 Monate leben und von dort über den Blattstiel in den Stengel eindringen konnten. Allerdings verursachten sie hier zunächst keine Stengelfäule sondern überlebten dort 11 Monate lang latent, ohne Symptome hervorzurufen (Tab. 20 und 21). Die behandelten Blätter waren entweder total vertrocknet oder abgefallen. Es hängt immer von der Bakterienkonzentration und den Umweltbedingungen ab, wie schnell und wie weit sich die Bakterien in der Pflanze vermehren (Kapitel 3.3). RUDOLPH (1995) nimmt an, dass die Bakterien nach natürlicher 
Infektion im Schleim aus extrazellularen Polysachariden (EPS und LPS) eingebettet und vor Austrocknung geschützt sind.

\subsubsection{Infektion über die Schnittstelle}

Das Auftreten der durch $X c p$ verursachten bakteriellen Pelargonienwelke wird stark durch vegetative Vermehrungsmethoden begünstigt. Beim Schneiden von Stecklingen gelangt das Bakterium leicht in offene Gefäße, in denen es sich über den gesamten Spross ausbreiten kann (GRIESBACH et al., 1999). Stengelinfektionen erfolgen häufig an den Schnittwunden von Stecklingen. Die Bakterien dringen in das Gefäßsystem ein und erreichen von hier aus das umliegende Stengelgewebe. Diese Infektionen führen nicht immer zu einer apparenten Symptomausprägung, sondern können mitunter für lange Zeit latent bleiben. Beim Schneiden von Stecklingen aus infizierten, äußerlich jedoch gesund erscheinenden Mutterpflanzen kann das Messer kontaminiert werden und der Erreger auf gesunde Mutterpflanzen und Stecklinge übertragen werden (REUTHER, 1975). Aus diesem Grund stellt die Desinfektion der Stecklingsmesser in Vermehrungsbetrieben eine unerlässliche Maßnahme dar. BURKI (1974) berichtete, dass nach jeder Verwendung das Messer desinfiziert werden muss. Die Messerdesinfektion ist aber nur dann sinnvoll, wenn gleichzeitig auch andere hygienische Maßnahmen befolgt werden, wie Desinfektion der Hände, von Böden, Kästen, Töpfen, Stellflächen usw..

In den vorliegenden Untersuchungen wurden Stecklinge von "Rosario“ an der Schnittstelle mit $10 \mu \mathrm{l} 10^{3}$ oder $10^{4} \mathrm{cfu} / \mathrm{ml}$ betropft. Nach 315 Tagen wurden zum ersten Mal Xcp nachgewiesen (Tab. 22). Dies war nur möglich, weil der Test durch Einschaltung einer Zwischenvermehrung empfindlicher gemacht werden konnte. Von diesen latent infizierten Pflanzen wurden Stecklinge gewonnen, in deren Basis mehrfach $X_{c p}$ detektiert wurde (Tab. 22). Damit konnte eindeutig nachgewiesen werden, dass die Stecklingsspender latent befallen waren. Die meisten davon stammten aus Mutterpflanzen, die mit dem geringeren Inokulum $\left(10^{3} \mathrm{cfu} / \mathrm{ml}\right)$ behandelt worden waren. Dieser Befund verdeutlicht das große Risiko der Verschleppung und Verbreitung des Bakteriums in der Praxis bei der Vermehrung von latent befallenen Mutterpflanzen. 


\subsubsection{Infektion über die Wurzeln}

In den vorliegenden Untersuchungen wurden durch das Begießen einer Pelargonienpflanze mit $4 \mathrm{ml}$ Bakteriensuspension von $10^{8} \mathrm{cfu} / \mathrm{ml}$ innerhalb von 2 Monaten deutliche Symptome hervorgerufen (Kap. 3.7). Damit wurden ältere Berichte über diesen Infektionsweg bestätigt. Nach MUNNECKE (1954) und MOORMAN (1999) treten bei natürlicher Infektion von Wurzeln die Symptome unter Umständen erst spät und uneinheitlich auf, und auch KIVILAAN und SCHEFFER (1958) konnten die Pflanzen über die Wurzeln infizieren. Ebenso berichtet BOSSHARD (1978), dass das Bakterium Pelargonien über die Blätter, Blattnarben oder Wurzel infizieren und sich in den Leitungsbahnen der Pflanze fortbewegen und vermehren kann. Dagegen konnte KURZE (1997) durch Wurzelinokulation von Pelargonien mit Xcp trotz hoher Bakterienkonzentration $\left(>10^{9}\right)$ keine eindeutigen Symptome erzeugen.

\subsection{4 Übertragung durch Erde}

Der Boden ist als Infektionsquelle für phytopathogene Bakterien bereits lange bekannt (KLEINHEMPEL et al., 1989). Nach MUNNECKE (1954) konnte Xcp in Kalifornien bis zu drei Monate in feuchtem Ackerboden überleben. KENNEDY et al. (1987) berichten, dass Xcp in Pflanzenteilen im Boden nur 11 Tage, aber in einem trockenen Pelargonienblatt 221 Tage überlebte. BOSSHARD et al. (1979) stellten fest, dass Xcp durch Bodenmikroorganismen gehemmt wurde, aber bei totaler Ausschaltung der Konkurrenz fähig war, im Substrat zu leben und sich zu vermehren. Im infizierten Pflanzenmaterial waren die Bakterien relativ geschützt, bis das Gewebe verfault war. Mit infiziertem Pflanzenmaterial verseuchtes Substrat ist deshalb eine gefährliche Infektionsquelle.

Das Überleben von Xcp im Kompost wurde von WÖLK und SARKAR (1994) untersucht. Wenn Komposterde mit hochkonzentrierter Bakteriensuspension vermischt wurde, konnten die Bakterien noch nach 14 Monaten nachgewiesen werden. Wurden zusätzlich infizierte Pelargonienstengel in den Kompost eingebracht, überlebten die Bakterien sogar 26 Monate. Diese Befunde widersprechen etwas der Meinung, dass $X c p$ nicht fähig ist, für längere Zeit im Boden saprophytisch zu überleben, wie z. B. Agrobacterium tumefaciens (LEBEN, 1973).

In der Klimakammer gelang es in unseren Versuchen nicht, über mit $X c p$ verseuchte Erde Pelargonien zu infizieren (Kap. 3.6). Für das Misslingen können diverse Gründe ange- 
nommen werden. Wahrscheinlich wurden die phytopathogenen Bakterien durch Bodenmikroorganismen so stark gehemmt, dass eine Infektion der unverletzten Wurzeln im Versuchszeitraum nicht stattfand. Außerdem waren die Pflanzen dieses Versuches, bedingt durch mehrfache Störungsfälle in der Klimakammer, in einem recht schlechten Zustand und wuchsen kümmerlich. Schlecht versorgte Pelargonien sind erfahrungemäß nur schwach anfällig für Xcp (Kap. 4.4).

Da andererseits ein Herausdiffundieren der Bakterien aus stark erkrankten Pflanzen in die umgebende Erde festgestellt wurde (Abb. 14), und da durch Begießen der Töpfe mit Bakteriensuspension innerhalb kurzer Zeit die Krankheit ausgelöst wurde (Kap. 3.7), ist sehr wahrscheinlich, dass Xcp über das Bodenwasser Nachbarpflanzen infizieren kann.

\subsection{5 Übertragung durch das Wasser}

Durch Pflanzenkontakt und Überkopfbewässerung oder Spritzwasser und Sprühnebel ist die Möglichkeit einer Übertragung über das Wasser gegeben (DOUGHERTY et al., 1974). Dies gilt besonders bei der Kultur im Freien (DAUGHTREY und MACKSEL, 1993). Nach KREBS (1992a) findet in geschlossenen Kultursystemen keine Übertragung von Xcp statt, wenn die Nährlösung nicht den Wurzelraum durchspült. Unsere Untersuchungen zeigten jedoch, dass die Bakterien durch das Begießen mit kontaminiertem Wasser Pelargonien systemisch befallen können (Tab. 25). Kontaminiertes Gießwasser muss deswegen als eine potenzielle Quelle für die Infektion gesunder Pelargonien in Betracht gezogen werden.

\subsection{6 Übertragung durch den Samen}

In den hier durchgeführten Untersuchungen wurden nur die Samen der alternativen Wirtspflanze Geranium pusillum untersucht. Dort konnten die Bakterien nachgewiesen werden. Da die Bakterien in unseren Versuchen mit Pelargonien häufig in Blütenknospen, Dolden und im Blütenstengel in Konzentrationen bis zu $10^{8} \mathrm{cfu} / \mathrm{g}$ nachgewiesen wurden, wird angenommen, dass die Bakterien auch Pelargonien-Samen besiedeln können (Kap. 3.4.4). Von anderen Autoren wird der Erregerübertragung durch Samen bei Pelargonien nur eine geringe Bedeutung zugemessen (HEIMANN, 1973; BRÖTHER, 1979). So konnte BRÖTHER (1981b), nach Untersuchung von 500 Pelargoniensamen nur in 0,2\% Xcp nachweisen, und KOUCHEKI (1973b) fand 1,8\% Xcp-infizierte Pelargoniensamen. 


\subsection{Vorkommen von $X c p$ auf anderen Arten der Familie Geraniaceae}

Die Bedeutung von Nichtwirtspflanzen für phytopathogene Bakterien wurde bereits mehrfach untersucht. ERCOLANI et al. (1974) fanden Pseudomonas syringae pv. syringae (Erreger der Braunfleckigkeit von Buschbohnen) epiphytisch auf Zottelwicken (Vicia villosa), die in der Nähe der Bohnenfelder wuchsen. In Kalifornien besiedelte das Tomatenpathogen Pseudomonas syringae pv. tomato epiphytisch verschiedene Unkräuter (McCARTER et al., 1983). LINDEMANN et al. (1984) isolierten epiphytische Populationen von Pseudomonas syringae pv. syringae von Maisblättern (Zea mays), Winterroggen (Secale cereale) und Disteln (Carduus mutans). AL-SHINAWI (1996) berichtete, dass Pseudomonas syringae pv. coriandricola in der Lage war, sich zwei Monate lang auf künstlich besprühten Blättern von Weizen (Triticum aestivum), Hanf (Cannabis sativa) und Acker-Kratzdistel (Cirsium arvense) aufzuhalten.

Für Xcp berichtete bereits LEWIS (1914), das der bakterielle Erreger die Gattungen Erodium (wild crane`s bill) und Pelargonium befiel. Hiermit stimmen unsere Ergebnisse überein, da Erodium cicutorium besonders anfällig reagierte. Nach BRADBURY (1986) werden verschiedene Geranium-Arten infiziert. Über die hier untersuchten anfälligen Arten Geranium dissectum und G. pisillum sind bisher keine Angaben aus der Literatur bekannt. Von GRIESBACH et al. (1999) liegen umfangreiche Untersuchungsergebnisse über die Anfälligkeit verschiedener Pelargonium-Arten vor.

Nach BUGBEE und ANDERSON (1963) können die Bakterien leicht durch weiße Fliegen (Trialeurodes spp.) übertragen werden, so dass von Xcp befallene Geranium-Arten, die häufig in Gärten angepflanzt werden, immer wieder zur Neu-Infektion von Pelargonienkulturen führen können.

Bei den hier vorgelegten Untersuchungen wurde zunächst geprüft, inwieweit Erodium cicutorium (Reiherschnabel), Geranium dissectum (schlitzblättriger Storchschnabel) und Geranium pisillum (kleiner Storchschnabel) als Wirtpflanze von Xcp geeignet sind. Im Stengel von Geranium pisillum vermehrten sich die Bakterien bis zu 9,3 x $10^{8} \mathrm{cfu} / \mathrm{g}$ Frischgewicht innerhalb von 8 Tagen. Die inokulierten Pflanzen zeigten Welkesymptome, und nach 3 Wochen brachen sie zusammen. Daraus war ersichtlich, dass diese Unkräuter zumindest künstlich durch $X c p$ infiziert werden können. Ob die Bakterien über längere Zeitintervalle auf diesen Pflanzen epiphytisch existieren können, konnte nicht untersucht werden, weil 
die inokulierten Pflanzen in kurzer Zeit völlig eingingen. Das Bakterium wurde auch in den Blättern und Früchten detektiert. Solche Pflanzen in der Nähe von Pelargonienkulturen können ein Infektionspotenzial während der ganzen Vegetationsperiode darstellen und sollten daher sorgfältig vernichtet werden. 


\section{ZUSAMMENFASSUNG}

5.1 Für die Untersuchung der Latenz in einem Langzeitversuch von 68 Monaten wurden die Pelargoniensorten "Rosario" und "Isabell" am Stengel mit $10 \mu$ l einer Bakteriensuspension von 3 verschiedenen Konzentrationen $\left(10^{3}, 10^{4}\right.$ und $\left.10^{5} \mathrm{cfu} / \mathrm{ml}\right)$ inokuliert. Die Pflanzen wurden zur Hälfte bei 15 und $25^{\circ} \mathrm{C}$ aufgestellt. Von beiden Gruppen wurde nach 6 Monaten jeweils die Hälfte zur anderen Temperatur transferiert (d. h. von $15{ }^{\circ} \mathrm{C}$ nach 25 ${ }^{\circ} \mathrm{C}$ oder von $25^{\circ} \mathrm{C}$ nach $15{ }^{\circ} \mathrm{C}$ ). Um die quantitative Bestimmung der Bakterien in den inokulierten Pflanzen im Verlauf des Versuches zu erleichtern, wurde ein hoch virulenter Хср Stamm mit Resistenz gegen 100 ppm Rifampicin selektiert. Die AntibiotikaResistenz erwies sich nach längerer Passage über Nährböden oder die Wirtspflanze als stabil.

5.1.1 Auch das niedrigste Inokulum (1 - 6 Bakterienzellen pro Pflanze) führte zur Erkrankung und in vielen Fällen zu einer besonders langen Latenzperiode.

5.1.2 Die Sorte "Rosario“ reagierte anfälliger als "Isabell“. Dies zeigte sich vor allem in einem schnelleren Verlauf der Erkrankung bei "Rosario“ und darin, dass mehr Versuchspflanzen von "Rosario“ als von "Isabell“ erkrankten. Außerdem waren die maximalen Bakterienpopulationen in "Rosario" 10 -fach höher als in "Isabell".

5.1.3 Bei $25{ }^{\circ} \mathrm{C}$ erkrankten die Pflanzen zunächst innerhalb von 6 Monaten viel schneller als bei $15^{\circ} \mathrm{C}$. Bei $15^{\circ} \mathrm{C}$ erfolgte die Erkrankung zwar langsamer, aber kontinuierlicher, so dass am Ende des Versuches (nach 68 Monaten) von den bei $15{ }^{\circ} \mathbf{C}$ gehaltenen Pflanzen deutlich mehr erkrankt waren. Bei den wärmer gehaltenen Pflanzen starben die inokulierten Bakterien in denjenigen Pflanzen, in denen sie nicht innerhalb von 11 Monaten eine Erkrankung ausgelöst hatten, ganz ab.

5.1.4 Bei regelmäßiger, intensiver Düngung durchbrachen die Bakterien die Latenzphase schneller als bei geringer Düngung.

5.1.5 Die im Versuchszeitraum festgestellte maximale Latenzperiode betrug 57 Monate, ("Rosario“ $15^{\circ} \mathrm{C}$, inokuliert mit $10^{3} \mathrm{cfu} / \mathrm{ml}$ ).

5.1.6 Während der Latenzperiode betrug die Bakterienkonzentration in den Stengeln $\mathbf{1 0}^{2}$ $10^{3} \mathbf{~ c f u / g}$ Frischgewicht. Erst ab $10^{8} \mathrm{cfu} / \mathrm{g}$ Frischgewicht erschienen die typischen Krankheitssymptome. 
5.1.7 Vom Inokulationspunkt im Stengel breiteten die Bakterien sich akropetal und basipetal systemisch in der ganzen Pflanze aus. Maximale Bakterienkonzentrationen im Stengel waren 8,3 x 10 ${ }^{10} \mathrm{cfu} / \mathrm{g}$ bei "Rosario" und 9,5 x 10 ${ }^{9} \mathrm{cfu} / \mathrm{g}$ bei "Isabell“. Hohe Bakterienkonzentrationen ( $>10^{8} \mathrm{cfu} / \mathrm{g}$ ) wurden auch in Blütenknospen, Blütendolden und den Wurzeln gefunden. Die Nodien enthielten höhere Bakterienkonzentrationen als die Internodien.

5.2 In mehreren Versuchen wurden die Infektionswege und Übertragungsmöglichkeiten des Bakteriums untersucht.

5.2.1 Auf das Blatt aufgetropfte Bakteriensuspensionen konnten dort unter Gewächshausbedingungen epiphytisch 2 bis 2,5 Monate überleben. Innerhalb von 2 Monaten waren sie in das Blatt und den Blattstiel eingedrungen und hatten nach 5 Monaten den Stengel besiedelt.

5.2.2 Das Begießen der Topferde mit Bakteriensuspension führte zur Erkrankung mit hohen Bakterienkonzentrationen in den Wurzeln.

5.2.3 Von infizierten Pelargonienpflanzen diffundierten die Bakterien in die Erde und wurden in dem aus den Töpfen herauslaufenden Sickerwasser in Konzentrationen bis zu $10^{4}$ $\mathrm{cfu} / \mathrm{ml}$ nachgewiesen.

5.2.4 Schon sehr geringe Bakterienmengen (10 Xcp Zellen) reichten aus, um die Bakterien über die Schnittstelle in Stecklinge zu übertragen, und in den aufgewachsenen Pflanzen blieben die Bakterien über 1 Jahr unerkannt latent enthalten. Erst in den daraus gewonnenen Tochterstecklingen, bzw. Tochterpflanzen, traten Krankheitssymptome 16 Monate nach der Erstinokulation auf.

5.2.5 Eine Übertragung der Bakterien durch den Samen kann auch bei Pelargonien nicht ausgeschlossen werden.

5.2.6 Drei mit Pelargonien verwandte Pflanzenarten (Erodium cicutorium, Geranium dissectum, Geranium pusillum) waren anfällig für Xcp und zeigten 12 Tage nach Inokulation typische Krankheitssymptome und hohe Bakterienkonzentrationen ( $\left.>10^{8} \mathrm{cfu} / \mathrm{g}\right) \mathrm{im}$ Stengel. Bei Geranium pusillum wurden die Bakterien auch in den Samen nachgewiesen.

5.3 Nach unseren Ergebnissen ergeben sich folgende Empfehlungen für die Unterdrückung der Krankheit.

5.3.1 Kulturmaßnahmen: Mutterpflanzen für die Stecklingsgewinnung sollten für einen bestimmten Zeitraum (6 - 9 Monate) bei relativ hoher Temperatur (z. B. $25{ }^{\circ} \mathrm{C}$ ) gehalten 
und gleichzeitig gut gedüngt werden, da dann latent in der Pflanze vorkommende Bakterien die Krankheit auslösen können und eine Elimination dieser Pflanzen möglich ist.

5.3.2 Hygiene-Maßnahmen: Sämtliche Pflanzen mit Krankheitssymptomen müssen sofort entfernt werden. Es reicht nicht aus, bei wertvollen Mutterpflanzen nur die erkrankten Partien herauszuschneiden, da die Bakterien die Pflanzen systemisch besiedeln und auch in äußerlich gesunden Pflanzenteilen vorkommen können. Bei der Stecklingsgewinnung müssen die Schnittwerkzeuge jedes Mal sterilisiert werden, um die Bakterienübertragung aus latent befallenen Mutterpflanzen zu verhindern.

5.3.3 Sortenwahl: Bei der Pelargonienzüchtung sollte auch eine erhöhte Widerstandsfähigkeit gegen $X c p$ als Zuchtziel verfolgt werden. 


\section{KAPITEL III}

\section{VERGLEICH VON ANTISEREN ZUM NACHWEIS VON XANTHO- MONAS CAMPESTRIS PV. PELARGONII MIT VERSCHIEDENEN SEROLOGISCHEN METHODEN}

\section{EINLEITUNG}

Xanthomonas campestris pv. pelargonii wird sowohl über Samen als auch Meristemkulturen übertragen, am häufigsten wird das Bakterium jedoch bei der Vermehrung über Stecklinge verbreitet (GRIESBACH et al., 1985). Um eine Verschleppung des Erregers mit Stecklingen von latent infizierten Mutterpflanzen zu verhindern, ist deswegen ein regelmäßiger Test der Mutterpflanzen notwendig. Nach Empfehlungen der EPPO (European Plant Protection Organization) soll jede Pflanze eines Kernbestandes (nuclear stock) einmal pro Jahr auf Xanthomonas getestet werden, für Pflanzen des Vermehrungsbestandes (propagation stock) sind Stichprobentests vorgesehen (Anonym, 1992, 2002). Aus diesem Grunde liegt es nahe, bewährte serologische Methoden für andere Pflanzenkrankheiten (vor allem Virosen), wie den sogenannten ELISA, auch zur Prüfung für die Xanthomonas campestris pv. pelargonii $(X c p)$ einzusetzen.

Serologische Methoden werden schon seit vielen Jahren zur Idendifikation phytopathogener Bakterien eingesetzt (SCHAAD, 1979; HAMPTON et al., 1990; SCHAAD, 1990). ELISA-Verfahren (enzyme-linked immunosorbent assay) wurden zum ersten Mal in der Humanmedizin beschrieben und seit 1976 auch zum Nachweis von Viren in Pflanzen eingesetzt (CLARK et al., 1976). Damals hatte man mit der Anwendung vor allem im Obstund Kartoffelanbau begonnen. Mit dem sicheren Nachweis des Kartoffel-Blattroll-Virus (CASPER, 1977) und anderer Kartoffelviren wurde das ELISA-Verfahren für die Untersuchung von Kartoffeln zu einer wichtigen Testmethode.

Unter dem Aspekt der Eignung für Routineuntersuchungen großer Mengen von Pflanzenproben bietet sich der ELISA-Test auch für Bakteriosen an. So wurde der ELISA-Test zum Eliminieren von $X c p$-kontaminiertem Vermehrungsmaterial neben dem IF-Test von WESTERHOF und VAN RUITEN (1992) empfohlen. Zum Nachweis latent vorhandener Bakterien ist dieser Test mit den bisher zur Verfügung stehenden Antiseren aber noch problematisch, da die Sensitivität nicht so hoch ist wie im Immunfluoreszenz-Test oder bei dem 
mikrobiologischen Nachweis (Kapitel I). BRIELMAIER-LIEBETANZ et al. (1994) erzielten eine Empfindlichkeit von $10^{3}$ Zellen / ml mit dem DAS-ELISA-Verfahren zum Nachweis von Xanthomonas campestris pv. pelargonii in Pelargonienstengeln.

An die Empfindlichkeit müssen sehr hohe Anforderungen gestellt werden, da bereits wenige Xanthomonas-Keime zu einer Infektion bei Pelargonien führen können (SAUTHOFF, 1980). Wenige Bakterien genügen bereits, um eine Pflanze zu infizieren (Kapitel II). Als Nachteil des ELISA-Tests zum Nachweis von $X c p$ in Pelargonien wird von NAMETH et al. (1999) darauf hingewiesen, dass sowohl falsch-positive wie falsch-negative Ergebnisse vorkommen können. Auch elekronenmikroskopische Verfahren ermöglichen nicht die geforderte Nachweisempfindlichkeit und sind außerdem für Routinetests nicht geeignet (NEUHAUS und GIERSIEPEN, 1992).

In dieser Arbeit wurde deswegen überprüft, inwieweit die in der Praxis gegen Xcp im ELISA verwendeten Antiseren die Anforderungen sowohl an die Nachweisgrenze als auch an die Spezifität erfüllen, und ob es wesentliche Unterschiede zwischen den Antikörpern verschiedener Herkunft gibt. 


\section{MATERIAL UND METHODEN}

\subsection{Bakterienstämme}

Sämtliche Bakterienstämme wurden der „Göttinger Sammlung Phytopathogener Bakterien“ (GSPB) entnommen. Neben den 4 Xcp-Stämmen wurde auch ein Stamm von X. campestris pv. zinniae (nach FRANKE, 1994, pathogen für Pelargonien) sowie an Pelargonien als Saprophyten vorkommende Bakterien eingesetzt.

Tab. 1: Verwendete Bakterienstämme

\begin{tabular}{|c|c|c|}
\hline Bakterium & GSPB-Nr & Herkunft \\
\hline Xanthomonas campestris pv. pelargonii & 203 & $\begin{array}{l}\text { DSM 50859, isol. von Sauthoff } \\
\text { aus Pelargonium zonale (Nr. } \\
\text { 1248/9), BBA, Berlin }\end{array}$ \\
\hline Xanthomonas campestris pv. pelargonii & 1955 & $\begin{array}{l}\text { isol. von Pagel, Fa. Endisch, } \\
1990\end{array}$ \\
\hline Xanthomonas campestris pv. pelargonii & 1956 & $\begin{array}{l}\text { isol. von Krebs, PSA Hannover, } \\
1990\end{array}$ \\
\hline Xanthomonas campestris pv. pelargonii & 1957 & $\begin{array}{l}\text { isol. von Wohanka, Geisen- } \\
\text { heim, } 1990\end{array}$ \\
\hline Xanthomonas campestris pv. pelargonii & 2503 & $\begin{array}{l}\text { gewonnen von Batur-Michaelis } \\
\text { aus GSPB 1955, Göttingen, } \\
1996\end{array}$ \\
\hline Xanthomonas campestris pv. pelargonii & 2514 & $\begin{array}{l}\text { isol. von Brielmaier-Liebetanz, } \\
\text { (Nr.1586), BBA, Braun- } \\
\text { schweig, } 1997\end{array}$ \\
\hline Xanthomonas campestris pv. pelargonii & 2632 & $\begin{array}{l}\text { isol. von Berkelmann, (Nr. 54- } \\
\text { E), Geisenheim, } 1994\end{array}$ \\
\hline Xanthomonas campestris pv. pelargonii & 2636 & $\begin{array}{l}\text { isol. von Berkelmann, (Nr. 63- } \\
\text { E) Geisenheim, } 1995\end{array}$ \\
\hline Xanthomonas campestris pv. zinniae & 2188 & $\begin{array}{l}\text { ICMP 5762, isol. von Hayward } \\
\text { aus Zinnia elegans, } 1969\end{array}$ \\
\hline Erwinia herbicola & 450 & $\begin{array}{l}\text { NCPPB 601, isol. aus Apfel, } \\
\text { England, } 1958\end{array}$ \\
\hline Pseudomonas fluorescens & 1714 & G-1 \\
\hline
\end{tabular}




\subsection{Serologische Untersuchungen}

\subsubsection{ELISA (enzyme-linked immunosorbent assay)}

\subsubsection{Allgemeine Methodik}

Bei den meisten serologischen Untersuchungen wurde der DAS-ELISA (Double-antibodysandwich-Enzym-linked-immunosorbent assay) eingesetzt. Dem DAS-ELISA liegt eine Reaktion von Antigen und Antikörper zu einem stabilen Komplex in einer Mikrotiterplatte zu Grunde (CLARK \& ADAMS, 1976; REUTER \& SONNEBORN, 1981). Auf dieser Platte werden die einzelnen Komponenten nacheinander aufgetragen und gebunden. Nach jedem Schritt werden nicht reagierende, eventuell sogar hemmende Komponenten weggewaschen. Der Antigen-Antikörper-Komplex wird durch eine gekoppelte EnzymFarbreaktion dargestellt und ist damit photometrisch auswertbar.

ELISA-Techniken können die immunologischen Reaktionsprinzipien in kompetitive und nichtkompetitive Techniken unterteilen. Im kompetitiven ELISA können sowohl Makromoleküle als auch Haptene mit nur einem reaktiven Epitop quantifiziert werden, während der nicht kompetitive ELISA mindestens zwei Epitope am zu bestimmenden Molekül voraussetzt.

Der nicht kompetitive ELISA kann auf verschiedene Weise durchgeführt werden:

Wird die Probe zwischen zwei Antikörpern an der Platte gebunden, so spricht man von einem Sandwich-ELISA.

Folgt dem Schritt der Probenadsorption die Adsorption von einem oder mehreren nichtkonjugierten Antikörpern, so ist dies ein sogenannter indirekter ELISA. Folgt der Probenadsorption sofort die enzymmarkierte Antikörperzugabe, dann handelt es sich um einen direkten ELISA.

In dieser Arbeit wurde ein direktes ELISA-Verfahren nach BRIELMAIER-LIEBETANZ et al. (1994) durchgeführt (2.2.1.2). Wegen der relativ leichten Durchführbarkeit mit nur wenigen Arbeitsschritten und niedrigen Materialkosten wurden die Antiseren im direkten ELISA überprüft. Mit Hilfe dieses Tests können außerdem schnell wichtige Information über die Antiseren gewonnen werden.

Das Testprinzip besteht beim DAS-ELISA (Double-antibody-sandwich-enzyme-linkedimmunosorbent assay) aus vier Schritten: Zuerst werden die Antikörper durch Adsorption 
an die Polystyrolwände der ELISA-Platten gebunden (1. Schritt). Dann werden Bakterien (Antigene) von dem spezifischen Antikörper durch Adsorption an die Wände gebunden (2. Schritt). Bei diesem Schritt findet eine Antigen-Antikörper-Reaktion statt. Darauf folgt die Zugabe von enzymmarkierten Antikörpern, die spezifisch gegen Xcp Bakterien gerichtet sind (3. Schritt). Zuletzt wird das Substrat p-Nitrophenylphosphat zugegeben (4. Schritt). Das Enzym des Konjugats spaltet das Substrat. Dieses Spaltprodukt wird sichtbar durch Gelbfärbung, deren Intensität proportional der Bakterienkonzentration in der Probe ist. Diese wird nach einer bestimmten Zeit photometrisch gemessen.

Zwischen den Schritten müssen die Platten sorgfältig mit Waschpuffer gewaschen werden, um ungebundene Bestandteile und Spuren von löslichen Substanzen, die unspezifische Reaktionen verursachen könnten, zu entfernen. Die Farbintensität ist direkt abhängig von der Menge des gebundenen Enzyms.

\subsubsection{DAS-ELISA nach BRIELMAIER-LIEBETANZ}

Die meisten Untersuchungen wurden nach diesem Protokoll durchgeführt. Die Angaben sind in $\mu$ l je Kavität ausgedrückt.

\section{Tag}

1. Beschichtung mit $200 \mu \mathrm{l}$ spezifischem IgG, 1: 1000 verdünnt in Beschichtungspuffer, Inkubationszeit $4 \mathrm{~h}$ und Inkubationstemperatur $37^{\circ} \mathrm{C}$

2. Waschen mit Waschpuffer 3 x 3 min.

3. Zugabe des Antigens (Bakterien) in $200 \mu$ l Nutrient Broth oder Extraktionspuffer, Inkubationszeit über Nacht, Inkubationstemperatur $4{ }^{\circ} \mathrm{C}$.

\section{Tag}

4. Waschen mit Waschpuffer 3 x 3 min.

5. Zugabe von $200 \mu \mathrm{l}$ des mit alkalischer Phosphatase konjugierten Antiserums, 1:1000 verdünnt in Konjugatpuffer, Inkubationszeit 4,5 h und Inkubationstemperatur $37^{\circ} \mathrm{C}$ 6. Waschen mit Waschpuffer $3 \times 3$ min.

7. Hinzufügung von $200 \mu \mathrm{l}$ Substratlösung p-Nitrophenylphosphat-Na $\mathrm{N}_{2}-\mathrm{Salz}$ (= p-NPP, Firma Merck, $1 \mathrm{mg} / \mathrm{ml}$ ) in Substratpuffer, Inkubation im Dunkeln, Inkubationstemperatur $18-20^{\circ} \mathrm{C}$

8. Messen nach 30, 60 und 120 min 
Nach jedem Inkubationsschritt wurden die Mikrotiterplatten mit PBS-Tween-Puffer (300 $\mu l)$ gespült. Der Waschpuffer verblieb drei Minuten in den Vertiefungen, danach wurde die Platte kräftig ausgeschüttet. Der Waschgang wurde dreimal wiederholt. Das Waschen erfolgte mit einem Handwasch- und Absauggerät (Spectra II SLT Labinstruments).

Für die Tests wurden Mikrotiterplatten aus Polystyrol (mittlere Bindungskapazität, F-Typ, Fa. Greiner) verwendet. Die Inkubation der Platten erfolgte entweder bei $4{ }^{\circ} \mathrm{C}$ im Kühlschrank oder bei $37{ }^{\circ} \mathrm{C}$ im Inkubationsschrank. Um die Qualität des ELISA-Tests bezüglich seiner Nachweisempfindlichkeit zu überprüfen, wurden die Proben in zweifacher Wiederholung auf NGA- oder NGAR- Medium parallel ausplattiert. In jeder Platte wurden die Proben in zweifacher Wiederholung eingesetzt. Außerdem wurden als Leerwerte der jeweilige Puffer und das Substrat p-Nitrophenylphosphat mit inkubiert, um die Hintergrund-Extinktion zu erfassen. Die äußeren Tröge der Mikrotiterplatten wurden allerdings ausgelassen, da hier die Streuung zu groß war. Die photometrische Messung erfolgte nach 30, 60 und 120 min bei 405 nm mit dem „V max kinetic microplate reader“ von der Firma Molecular Devices.

\subsubsection{DAS-ELISA nach RABENSTEIN}

Dieses Protokoll wurde für die Überprüfung der Seren von Dr. RABENSTEIN befolgt.

\section{Tag}

1. Beschichten mit spezifischem Antikörper (in Beschichtungspuffer, IgG 1:1000), $100 \mu$ l je Kavität, Inkubation $4 \mathrm{~h}$ bei $37^{\circ} \mathrm{C}$

2. Waschen mit Waschpuffer 4 x 3 min

3. Auftragen der Probe (in Extraktionspuffer, Antigenverdünnung 1:5) $100 \mu$ l je Kavität, Inkubation über Nacht bei $4^{\circ} \mathrm{C}$

\section{Tag}

4. Waschen mit Waschpuffer $4 \times 3 \mathrm{~min}$

5. Zugabe von Konjugatlösung (AP-konjugierte spezifische Antikörper in Konjugatpuffer, Verdünnung 1:1000), $100 \mu \mathrm{l}$ je Kavität, Inkubation $4 \mathrm{~h}$ bei $37^{\circ} \mathrm{C}$

6. Waschen mit Waschpuffer $5 \times 3 \mathrm{~min}$

7. Einpipettieren der Substratlösung (1 mg / ml p-NPP in Substratpuffer), 200 l je Kavität, Inkubation bei Raumtemperatur im Dunkeln 
8. Messen bei $405 \mathrm{~nm}$ nach 60 und $120 \mathrm{~min}$

Nach diesem Schema wurde mit dem monoklonalen Antikörper der DAS-ELISA durchgeführt. Die Verdünnungen waren bei dem monoklonalen Antikörper 1:500 und bei dem Konjugat 1:1000.

\subsubsection{Verwendete Puffer}

1. Beschichtungspuffer (nach CLARK und ADAMS, 1977)

$\begin{array}{lll}\mathrm{Na}_{2} \mathrm{CO}_{3} & 1,59 & \mathrm{~g} \\ \mathrm{NaHCO}_{3} & 2,93 & \mathrm{~g} \\ \mathrm{NaN}_{3} & 0,2 & \mathrm{~g} \\ \text { a. dest. } & 1000 & \mathrm{ml} \\ \mathrm{PH} & 9,6 & \end{array}$

2. Phosphatgepufferte physiologische Kochsalzlösung (PBS) (CASPER und MAYER, 1981)

$\begin{array}{lll}\mathrm{NaCI} & 8,0 & \mathrm{~g} \\ \mathrm{KH}_{2} \mathrm{PO}_{4} & 0,2 & \mathrm{~g} \\ \mathrm{Na}_{2} \mathrm{HPO}_{4} \text { x } 12 \mathrm{H}_{2} \mathrm{O} & 1,4 & \mathrm{~g} \\ \mathrm{KCl} & 0,2 & \mathrm{~g} \\ \mathrm{NaN}_{3} & 0,2 & \mathrm{~g} \\ \text { Tween } 20 & 0,5 & \mathrm{ml} \\ \text { a. dest. } & 1000 & \mathrm{ml} \\ \mathrm{pH} & 7,4 & \end{array}$

\section{Konjugatpuffer}

Waschpuffer (PBS) $\quad 1000 \mathrm{ml}$

Polyvinylpyrolidon (PVP) $20 \quad \mathrm{~g}$

Rinderserumalbumin $\quad 2 \quad \mathrm{~g}$ 
4. Substratpuffer (nach CLARK und ADAMS, 1977)

$\begin{array}{lll}\text { Diethanolamin } & 97 & \mathrm{ml} \\ \mathrm{MgCI}_{2} \text { x } 6 \mathrm{H}_{2} \mathrm{O} & 0,2 & \mathrm{~g} \\ \mathrm{NaN}_{3} & 0,2 & \mathrm{~g} \\ \text { Bidest. Wasser } & 1000 & \mathrm{ml} \\ \mathrm{pH} & 9,8 & \end{array}$

\section{Extraktionspuffer}

Es wurden drei verschiedene Extraktionspuffer eingesetzt:

a) PBS $+0,05 \%$ Tween $20+1 \%$ PVP

b) Extraktionspuffer nach Brielmaier-Liebetanz

$8 \mathrm{~g} / \mathrm{l}$ Nutrient Broth (Difco)

15 min bei $120^{\circ} \mathrm{C}$ autoklavieren

c) Pelargonium-Puffer (nach Fa. LOEWE)

$\begin{array}{lll}\text { TRIS } & 12,11 & \mathrm{~g} \\ \text { PVP (K25) } & 20 & \mathrm{~g} \\ \text { Bovine Serum Albumin } & 2 & \mathrm{~g} \\ \text { a. dest. } & 1000 & \mathrm{ml} \\ \mathrm{pH} & 8,6 & \end{array}$

\subsubsection{Vorbereitung der Bakterien}

Alle Xanthomonas-Stämme wurden auf NGA-Agar, Erwinia herbicola und Pseudomonas fluorescens auf King-B-Agar für 24 Stunden kultiviert und mit Probenpuffer (PBS + 0,05\% Tween $20+1 \%$ PVP) oder Nutrient Broth suspendiert. Mit einem Spektralphotometer (BAUSCH \& LOMB Spectronic 20) wurde die optische Dichte auf 0,06 bei einer Wellenlänge von $660 \mathrm{~nm}$ eingestellt, welches einer Lebendkeimzahl von ca. $10^{8} \mathrm{cfu} / \mathrm{ml}$ entspricht. Für den ELISA-Test wurden immer die Bakterienkonzentrationen $10^{6}, 10^{5}, 10^{4}$ und $10^{3} \mathrm{cfu} / \mathrm{ml}$ gewählt. Die für den jeweiligen ELISA-Test tatsächlich eingesetzten Bakte- 
rien-Konzentrationen wurden bei jedem Versuch durch Ausplattierung einer Verdünnungsreihe auf dem NGA-Medium ermittelt.

Folgende Varianten wurde im ELISA geprüft:

Bakterienreinkultur im Probenpuffer, infizierte Pflanzen.

Als Negativ-Kontrollen wurden mitgetestet:

Probenpuffer ohne Bakterien,

Pflanzensaft nicht inokulierter Pelargonien.

\subsubsection{Photometrische Auswertung}

Der DAS-ELISA- Test wurde wie unter 2.2.1.2 und 2.2.1.3 beschrieben durchgeführt. Die äußeren Tröge der Mikrotiterplatten wurden ausgelassen, da sie eine zu große Streuung aufweisen. Jede Probe wurde als zweifache Wiederholung angelegt und der Mittelwert in die Auswertung übernommen.

Die Auswertung erfolgte in den meisten Fällen nach 120 min Substratinkubation. In einigen Fällen wurde die Inkubation bis 24 Stunden ausgedehnt, um klare Reaktionsunterschiede messen zu können.

Parallel zu jedem ELISA-Versuch wurde von allen verwendeten Proben aus 1:10 Verdünnungsstufen $0,1 \mathrm{ml}$ auf NGA-Medium ausplattiert und $2 \mathrm{~d}$ bei $25^{\circ} \mathrm{C}$ inkubiert, um die enthaltenen Lebendbakterien zu erfassen.

\subsubsection{Fluoreszenztechnische Methoden}

Bei der Immunfluoreszenz (IF) werden die Antikörper mit einem Fluoreszenzfarbstoff gekoppelt. Nach Anregung mit UV-Licht (400 - 550 nm) emittieren diese Fluorochrome Licht längerer Wellenlängen. Dieser Test ist besonders gut zum Nachweis von Pilz- und Bakterienzellen in Pflanzengewebe und Boden geeignet, da die Zellen direkt sichtbar gemacht werden können (DE BOER, 1990).

Zur Anwendung kam eine indirekte Immunfluoreszenzmethode. Nach diesem Verfahren wurden neben dem homologen ein Sekundärserum mit gegen das Kaninchenserum gerichteten Antikörpern eingesetzt, welche mit dem gelb fluoreszierenden Fluorochrom FITC (Fluoreszein-Isothiocyanat) gekoppelt waren. 


\subsubsection{Verwendete Puffer}

1) Phosphatpuffer-Saline (PBS)

$\begin{array}{lll}\mathrm{Na}_{2} \mathrm{HPO}_{4} \times 12 \mathrm{H}_{2} \mathrm{O} & 2,7 & \mathrm{~g} \\ \mathrm{NaH}_{2} \mathrm{PO}_{4} \times 2 \mathrm{H}_{2} \mathrm{O} & 0,4 & \mathrm{~g} \\ \mathrm{NaCl} & 0,8 & \mathrm{~g} \\ \text { Dest . Wasser } & 1000 & \mathrm{ml} \\ \mathrm{pH} & 7,2 & \end{array}$

2) Glycerol-Phosphat-Puffer (GPB)

$\begin{array}{lll}\mathrm{Na}_{2} \mathrm{HPO}_{4} \text { × } 12 \mathrm{H}_{2} \mathrm{O} & 3,2 & \mathrm{~g} \\ \mathrm{NaH}_{2} \mathrm{PO}_{4} \text { × } 2 \mathrm{H}_{2} \mathrm{O} & 0,15 & \mathrm{~g} \\ \text { Glycerin } & 50 & \mathrm{ml} \\ \text { Dest.Wasser } & 1000 & \mathrm{ml} \\ \mathrm{pH} & 7,6 & \end{array}$

\subsubsection{Immunfluoreszenztest (IF-Test)}

Zunächst wurden die Bakterien wie unter 2.2.1.5 beschrieben angezogen und daraus Suspensionen mit $10^{2}$ bis $10^{6}$ Zellen/ml hergestellt. Aus den Bakteriensuspensionen sowie aus befallverdächtigen Pflanzenhomogenaten wurden je $20 \mu \mathrm{l}$ in ein Fenster eines speziellen 12-Fenster-Objektträgers für Fluoreszenzmikroskopie (ICN BIOMEDICALS, INC) pipettiert und bei $60{ }^{\circ} \mathrm{C}$ direkt auf der Wärmebank 20 min fixiert. Die so angeklebten Proben wurden für 10 min in 96\% Ethanol fixiert, getrocknet und mit Phosphatpuffer abgespült. Danach konnten die 1:100 in PBS Puffer verdünnten AK (20 $\mu \mathrm{l} /$ Fenster) aufgetragen und in einer feuchten Kammer 30 min im Dunklen bei $37{ }^{\circ} \mathrm{C}$ inkubiert werden. Nachdem die Proben mit Puffer gespült und Luft getrocknet wurden, erfolgte die Auftragung des FITCkonjugierten Ziegen-Anti-Kaninchenserums (Sigma, Produkt-Nummer F-0382). Das FITC-Konjugat wurde in PBS-Puffer 1:100 verdünnt und mit jeweils $20 \mu$ pro Fenster aufgetragen. Die Inkubation erfolgte in einer feuchten Kammer im Dunklen für 30 min bei $37^{\circ} \mathrm{C}$. Nach der Inkubation wurde gründlich gespült, um ungebundenen Farbstoff zu entfernen, und in der Luft bei Zimmertemperatur getrocknet. 
Danach wurden zu jedem Fenster $5 \mu$ l Glycerol-Phosphat-Puffer gegeben, bevor ein Deckglas aufgelegt wurde. Anschließend wurden die Proben im Auflicht-Fluoreszenzmikroskop (BP 450-490 Anregungs- und LP 430 Sperrfilter für FITC bzw. BP 515-560 Anregung) im Dunklen untersucht. 


\section{ERGEBNISSE}

Zur Untersuchung der latent befallenen Pflanzen wurden zunächst Reinkulturen der Bakterien geprüft, um die optimale Nachweisgrenze und die Qualität der Antikörper festzustellen. Hierbei wurden verschiedene Konzentrationen von polyklonalen und monoklonalen Antikörpern sowie unterschiedliche Inkubationstemperaturen und Extraktionspuffer getestet. Als Ergebnisse dieser Optimierungsarbeit werden im folgenden für jede Kombination von Antiserum und Pathogen jeweils die besten erhaltenen Eichkurven und das Ergebnis darauf basierender Messungen vorgestellt.

In der Immunologie gelten als untere Nachweisgrenze die Werte, die größer als der Mittelwert der Negativkontrolle plus seiner dreifachen Standardabweichung sind (CLARK, 1981).

In dieser Arbeit wurden folgende Kriterien berücksichtigt, um die Proben als positiv auszuwerten:

- Wenn die Positivkontrolle nach 2 h (meistens die Extinktionswerte für $10^{3} \mathrm{cfu} / \mathrm{ml}$ ) zwischen $\mathrm{E}_{405 \mathrm{~nm}}=$ 0,13 - 0,2 lag, sollte die Negativkontrolle $\mathrm{E}_{405 \mathrm{~nm}}=0,09$ nicht überschreiten. Der Mittelwert der Negativkontrolle wurde mit dem Mittelwert der Positivkontrolle verglichen. Bei unsicheren Ergebnissen wurde weitere 3 - 24 h inkubiert.

- Es wurde auf die Extinktionswerte bei verschiedenen Konzentrationen geachtet.

- Nach jedem Versuch wurden direkt nach Ausplattierung der Proben die auf den Petrischalen wachsenden Bakterienkolonien gezählt um festzustellen, ob die Ergebnisse im DAS-ELISA mit den mikrobiologischen Befunden übereinstimmten.

\subsection{Die verwendeten Antiseren zum Nachweis von Xcp im ELISA-Test}

Für die geprüften Antiseren wurden von den Produzenten/Firmen folgende Angaben gemacht:

Monoklonales Antiserum aus Aschersleben: Aus Mäusen (Balb/c); immunisiert gegen Xcp-Stamm (4/2b); mit Bezeichnung 5F8; Subklasse IgM und fünf Bindungsarme; entwickelt für DAS-ELISA und IF; reagiert mit löslichen Stoffwechselprodukten von Xcp (evtl. Lipopolysaccharide); keine Kreuzreaktion mit anderen Xanthomonaden; reagiert im Westernblot mit hochmolekularen Lipopolysachariden. 
Publikationen: RABENSTEIN, F; ZIELKE, R.; NAUMANN, K. (1994): Nachweis von Xanthomonas campestris pv. pelargonii mit polyklonalen Antiseren und monoklonalen Antikörpern. Vorträge für Pflanzenzüchtung 28, 327-329.

Polyklonales Antiserum aus Aschersleben: Aus Kaninchen; immunisiert gegen XcpStamm 4/2b; mit Bezeichnung 4717; Kreuzreaktion mit anderen Bakterienarten der Gattung Xanthomonas.

Publikationen: RABENSTEIN, F; ZIELKE, R. und NAUMANN, K. (1994): Nachweis von Xanthomonas campestris pv. pelargonii mit polyklonalen Antiseren und monoklonalen Antikörpern. Vorträge für Pflanzenzüchtung 28, 327-329.

RABENSTEIN, F; ZIELKE, R. und PROLL, E. (1994): Entwicklung immundiagnostischer Methoden unter Verwendung von polyklonalen Antiseren und monoklonalen Antikörpern für den Nachweis von Xanthomonas campestris pv. pelargonii und pv. begoniae in Zierpflanzen. Jahresberichte der BAZ.

Polyklonales Antiserum von BIOREBA: Aus Kaninchen IgG; immunisiert gegen einen Xcp-Stamm der Eidgenössischen Forschungsanstalt für Pflanzenbau (RAC) in Nyon, ursprünglich in Deutschland isoliert; Konjugat: Polyklonales IgG konjugiert mit alkal. Phosphatase; Nachweisempfindlichkeit $10^{3}-10^{4}$ cfu pro ml im ELISA auf NUNC MaxiSorp F96 Platten; Kreuzreaktionen nur mit nahe verwandten Xanthomonaden, wie Xanthomonas campestris pv. campestris bei hohen Konzentrationen.

Publikationen: BRIELMAIER-LIEBETANZ, U. und SADOWSKA-RYBACK, M. (1994): Vergleich von Antiseren zum Nachweis von Xanthomonas campestris pv. pelargonii im enzyme-linked immunosorbent assay (ELISA). Nachrichtenbl. Deut. Pflanzenschutzd. 46: $37-40$.

Polyklonales Antiserum von Fa. LOEWE: Aus Kaninchen; immunisiert gegen Xcp-Stamm aus Aschersleben; Nachweisempfindlichkeit $10^{3}$ cfu pro ml.

Polyklonales Antiserum vom IPO (Niederlande): Aus Kaninchen; immunisiert gegen XcpStamm IPO Nr. 272 (CNPB 1718), dieser Stamm wurde im Jahr 1986 in Angers isoliert; die Hersteller (J. van BECKHOVEN, persönlich. Mitteilung) empfehlen eine Verdünnung des Antiserums von 1:1000 (entspricht einer endgültigen Verdünnung von 1:2000) und garantieren dann eine Nachweisempfindlichkeit von $10^{5} \mathrm{cfu} / \mathrm{ml}$. 
Alle Antiseren wurden jeweils parallel auf einer Mikrotiterplatte unter gleichen Bedingungen geprüft. Folgende Antikörperverdünnungen wurden vom Produzenten empfohlen (Tab. 2):

Tab. 2: Art und Herkunft der in den ELISA-Tests eingesetzten Antiseren

\begin{tabular}{|c|c|c|c|c|}
\hline $\begin{array}{l}\text { Art der } \\
\text { Antiseren }\end{array}$ & $\begin{array}{l}\text { gewonnen } \\
\text { aus }\end{array}$ & $\begin{array}{l}\text { Bezeich- } \\
\text { nung }\end{array}$ & $\begin{array}{l}\text { empfohlene } \\
\text { Verdünnung }\end{array}$ & Herkunft \\
\hline $\begin{array}{l}\text { Monokl. IgG } \\
\text { Konjugat }\end{array}$ & Mäusen & $\begin{array}{l}\text { 5F81(1519) } \\
\text { 5F8 }\end{array}$ & $\begin{array}{l}1: 500 \\
1: 1000\end{array}$ & $\begin{array}{l}\text { Rabenstein, BAZ, Aschersle- } \\
\text { ben (vom 24. 06. 1996) }\end{array}$ \\
\hline $\begin{array}{l}\text { Polykl. IgG } \\
\text { Konjugat }\end{array}$ & Kaninchen & $\begin{array}{l}4717 \\
4717\end{array}$ & $\begin{array}{l}1: 1000 \\
1: 1000\end{array}$ & $\begin{array}{l}\text { Rabenstein, BAZ, Aschersle- } \\
\text { ben (vom 28. 11. 1996) }\end{array}$ \\
\hline $\begin{array}{l}\text { Polykl. IgG } \\
\text { Konjugat }\end{array}$ & Kaninchen & $\begin{array}{l}170112 \\
170122\end{array}$ & $\begin{array}{l}1: 1000 \\
1: 1000\end{array}$ & $\begin{array}{l}\text { Fa. Bioreba, Reinach, } \\
\text { Schweiz (vom 24. 07. 1998) }\end{array}$ \\
\hline $\begin{array}{l}\text { Polykl. IgG } \\
\text { Konjugat }\end{array}$ & Kaninchen & $\begin{array}{l}07077 \\
07077\end{array}$ & $\begin{array}{l}1: 200 \\
1: 200\end{array}$ & $\begin{array}{l}\text { Fa. Loewe, Sauerlach } \\
\text { (vom 01. 07. 1998) }\end{array}$ \\
\hline $\begin{array}{l}\text { Polykl. IgG } \\
\text { Konjugat }\end{array}$ & Kaninchen & $\begin{array}{l}85513 \text { FG4 } \\
85513 \text { FG6 }\end{array}$ & $\begin{array}{l}1: 1000 \\
1: 1000\end{array}$ & $\begin{array}{l}\text { van der Wolf, IPO, Wagenin- } \\
\text { gen, Niederlande (vom } 15 . \\
\text { 10. 1998) }\end{array}$ \\
\hline
\end{tabular}

Der DAS-ELISA wurde wie oben beschrieben (2.2.1.2 und 2.2.1.3) durchgeführt. Die Farbreaktion wurde mit einem ELISA-Photometer bei einer Wellenlänge von $405 \mathrm{~nm}$ gemessen. Als Negativkontrolle diente dasselbe Gemisch ohne Bakterien.

\subsection{Antiseren der BAZ, Aschersleben}

\subsubsection{Ermittlung der optimalen Konzentration für das monoklonale Antiserum und Serum-Konjugat}

Der DAS-ELISA wurde nach Dr. RABENSTEIN (persönliche Mitteilung) wie unter 2.2.1.3 beschrieben durchgeführt. Demnach sollte das monoklonale Antiserum 1:500 und das Serum-Konjugat 1:1000 verdünnt werden. Mit den empfohlenen Konzentrationen 
konnte $X c p$ nicht nachgewiesen werden. Deswegen wurde eine Reihe verschiedener Verdünnungen vom Serum und Konjugat auf ihre Eignung überprüft (Tab. 3a und 3b).

Tab. 3a: Ermittlung der optimalen Antiserum- und Konjugatverdünnungen mit den monoklonalen Antikörpern von Rabenstein (Aschersleben). Messung der Extinktion bei 405 nm nach 2 h Inkubation

\begin{tabular}{ll|l|lc}
\hline \multicolumn{2}{l|}{$\begin{array}{l}\text { Verdünnungsgrad von } \\
\text { Antiserum }\end{array}$} & Konjugat & & \multicolumn{2}{|l}{$\begin{array}{l}\text { Kakterienkonzentration (cfu/ml) } \\
10^{4}\end{array}$} \\
\hline \hline $1: 100$ & $1: 200$ & 0,279 & 0,782 & 0,299 \\
$1: 200$ & $1: 400$ & 0,133 & 0,236 & 0,235 \\
$1: 300$ & $1: 600$ & 0,119 & 0,121 & 0,117 \\
$1: 400$ & $1: 800$ & 0,140 & 0,104 & 0,111 \\
\hline
\end{tabular}

Mit den monoklonalen Antikörpern (Verdünnung 1:100) war die Bakterienkonzentration von $10^{4} \mathrm{cfu} / \mathrm{ml}$ nicht deutlich nachweisbar. Tabelle 3a gibt die Mittelwerte von 2 Wiederholungen wieder. Erst bei einer Bakterienkonzentration von $10^{6} \mathrm{cfu} / \mathrm{ml}$ wurde ein Extinktionswert $\mathrm{E}_{405 \mathrm{~nm}}=0,782$ und $\mathrm{E}_{405 \mathrm{~nm}}=$ 0,279 für die Kontrolle gemessen. Bei einer Serumverdünnung von 1:200 ließ sich ein geringer Unterschied in der Extinktion zwischen Bakteriensuspension und Nullkontrolle feststellen aber nicht zwischen den beiden Bakterienkonzentrationen $\left(10^{6}\right.$ und $\left.10^{4} \mathrm{cfu} / \mathrm{ml}\right)$. Beim weiteren Verdünnen des Serums war ein Bakteriennachweis auch bei $10^{6} \mathrm{cfu} / \mathrm{ml}$ nicht möglich, da die erhaltenen Probenwerte ähnlich niedrig wie die der Kontrolle lagen (Tab. 3a). Auch nach einer längeren Inkubation (24 h) wurde der Nachweis der Bakterien nicht sicherer (Tab. 3b).

Tab. 3b: Ermittlung der optimalen Antiserum- und Konjugatverdünnungen mit den monoklonalen Antikörpern von Rabenstein (Aschersleben). Messung der Extinktion bei 405 nm nach 24 h Inkubation

\begin{tabular}{ll|l|lc}
\hline \multicolumn{2}{l|}{$\begin{array}{l}\text { Verdünnungsgrad von } \\
\text { Antiserum }\end{array}$} & Konjugat & & \multicolumn{2}{|l}{$\begin{array}{l}\text { Kakterienkonzentration (cfu/ml) } \\
10^{4}\end{array}$} \\
\hline \hline $1: 100$ & $1: 200$ & 1,978 & 4,000 & 2,113 \\
$1: 200$ & $1: 400$ & 1,329 & 1,467 & 0,609 \\
$1: 300$ & $1: 600$ & 0,716 & 0,480 & 0,716 \\
$1: 400$ & $1: 800$ & 1,017 & 0,303 & 0,812 \\
\hline
\end{tabular}


Weiterhin wurde nach dem ersten Schritt mit 3\%-iger Magermilch oder mit bovinem Serumalbumin (BSA) 30 min bei $37^{\circ} \mathrm{C}$ inkubiert, um die freien Bindungsstellen abzusättigen (CHENG et al., 1982). Dadurch konnte die Empfindlichkeit nicht verbessert werden. Die Extinktionswerte waren sowohl bei der Positivkontrolle $\left(10^{6} \mathrm{cfu} / \mathrm{ml}\right)$ als auch bei der Negativkontrolle sehr gering $\left(\mathrm{E}_{405 \mathrm{~nm}}=0,08\right)$.

In den weiteren Versuchen wurde der monoklonale Antikörper immer 1:100 und das Konjugat 1:200 verdünnt. Zur Ermittlung der besten Bedingungen wurden verschiedene Varianten der Bakterienhauptkultur und der Antiserum-Verdünnung verglichen (Tab. 4). In Variante 1 wurden die Bakterien auf Nährboden nach RHODES (1959) vorkultiviert und in Konjugatpuffer aufgenommen. Nach der Hauptkultur auf Rhodes-Medium wurden die Bakterien in Konjugatpuffer suspendiert. Bei den Varianten 2 und 3 wurden die Bakterien auf YDC bzw. NGA kultiviert und in 3\%-iger Magermilch aufgenommen.

Tab. 4: Einfluss verschiedener Nährböden zur Bakterienanzucht und Verdünnungen des monoklonalen Antiserums auf den ELISA-Test bei 2 h Inkubation (GSPB 2503)

\begin{tabular}{|c|c|c|c|c|}
\hline $\begin{array}{l}\text { Nährmedium } \\
\text { für Haptkultur }\end{array}$ & $\begin{array}{l}\text { Antiserum } \\
\text { Verdünnung in }\end{array}$ & $\begin{array}{ll}\text { Kontrolle } & \text { (ohne } \\
\text { Bakterien) } & \end{array}$ & $\begin{array}{l}\text { Bakte } \\
\text { (cfu/m } \\
10^{6}\end{array}$ & $\begin{array}{l}\text { ntration } \\
10^{4}\end{array}$ \\
\hline Rhodes & Konjugat-Puffer & 0,167 & 0,389 & 0,221 \\
\hline YDC & 3\% Magermilch & 0,180 & 0,692 & 0,181 \\
\hline NGA & 3\% Magermilch & 0,150 & 0,178 & 0,159 \\
\hline
\end{tabular}

Die besten Ergebnisse für die hohe Bakterienkonzentration von $10^{6} \mathrm{cfu} / \mathrm{ml}$ wurden durch Variante 2 erzielt. In Variante 3 wurde sogar mit der hohen Bakterienkonzentration kein positives ELISA-Ergebnis erzielt. Offenbar wurde das monoklonale Antiserum an die auf NGA kultivierten Bakterien nicht gebunden.

\subsubsection{Ermittlung der optimalen Konzentration für das polyklonale Antiserum aus Aschersleben und die Konjugatverdünnung}

Der DAS-ELISA wurde nach Dr. RABENSTEIN (Aschersleben) wie unter 2.2.1.3 beschrieben durchgeführt. Nach Empfehlung des Serumherstellers sollten sowohl das polyklonale Antiserum sowie das Konjugat jeweils 1:1000 verdünnt werden. Mit diesen Kon- 
zentrationen konnte Xcp (Stamm 2503) nicht nachgewiesen werden. Deswegen wurden andere Verdünnungen überprüft (Tab. 5a).

Tab. 5a: Ermittlung der optimalen Antiserum- und Konjugatverdünnungen mit dem polyklonalen Antiserum von Rabenstein (Aschersleben), Messung der Extinktion bei 405 nm nach einer Inkubation von 2 h (Xсp 2503)

\begin{tabular}{ll|l|lc}
\hline $\begin{array}{l}\text { Verdünnungsgrad von } \\
\text { Antiserum }\end{array}$ & Konjugat & & Kontrolle & \multicolumn{2}{|l}{$\begin{array}{l}\text { Bakterienkonzentration (cfu/ml) } \\
10^{4}\end{array}$} \\
\hline $1: 200$ & $1: 200$ & 0,659 & 0,663 & 0,391 \\
$1: 400$ & $1: 400$ & 0,334 & 0,348 & 0,357 \\
$1: 600$ & $1: 600$ & 0,217 & 0,246 & 0,186 \\
$1: 800$ & $1: 800$ & 0,336 & 0,197 & 0,157 \\
\hline
\end{tabular}

Nach zweistündiger Inkubation konnten mit dem polyklonalen Antiserum Bakterienkonzentrationen von $10^{4}$ und $10^{6} \mathrm{cfu} / \mathrm{ml}$ mit den geprüften Antiserum-Konzentrationen nicht nachgewiesen werden (Tab. 5a). Deshalb wurden die Proben 24 h lang inkubiert (Tab. 5b).

Tab. 5b: Ermittlung der optimalen Antiserum- und Konjugatverdünnungen mit dem polyklonalen Antiserum von Rabenstein (Aschersleben), Messung der Extinktion bei $405 \mathrm{~nm}$ nach einer Inkubation von $24 \mathrm{~h}$

\begin{tabular}{ll|l|lc}
\hline $\begin{array}{l}\text { Verdünnungsgrad von } \\
\text { Antiserum }\end{array}$ & Konjugat & & \multicolumn{2}{|l}{$\begin{array}{l}\text { Kontrolle } \\
10^{6}\end{array}$} \\
\hline \hline $1: 200$ & $1: 200$ & 4,000 & 4,000 & 3,659 \\
$1: 400$ & $1: 400$ & 2,681 & 2,871 & 2,979 \\
$1: 600$ & $1: 600$ & 1,452 & 1,820 & 1,031 \\
$1: 800$ & $1: 800$ & 1,897 & 1,171 & 0,771 \\
\hline
\end{tabular}

In diesem Versuch ergab sich bei einer Bakterienkonzentration von $10^{6} \mathrm{cfu} / \mathrm{ml}$ und einer Serum- und Konjugatverdünnung von 1:600 noch ein Wert, der schwach über dem der Kontrolle lag, aber für einen sicheren Nachweis nicht ausreichte (Tab. 5b).

Auch in diesen Versuchen konnte die Nachweisempfindlichkeit durch eine Blockierung mit 3\%-iger Magermilchlösung nicht verbessert werden. Extinktionswerte bei der Positivund Negativkontrolle waren gleich und lagen bei $\mathrm{E}_{405 \mathrm{~nm}}=0,252$. 


\subsection{Antiserum von BIOREBA}

\subsubsection{Nachweisgrenze von $X c p$ mit dem polyklonalen Antiserum der Fa. BIOREBA}

Der DAS-ELISA wurde nach dem Protokoll BRIELMAIER-LIEBETANZ (2.2.1.2) durchgeführt. Aus einer auf dem NGA-Nährmedium gewachsenen Reinkultur des XcpStammes GSPB 2503 wurde eine Suspension hergestellt und die Bakteriendichte photometrisch eingestellt. Von gesunden Pelargonienstengeln wurden $0,5 \mathrm{~g}$ in sehr dünne Scheiben mit dem Skalpell in kleine Würfel zerschnitten und zu $1 \mathrm{ml}$ Nutrient Broth gegeben. Zu diesen "Pflanzenextrakt im Nutrient Broth“ wurde 0,1 ml der Bakteriensupension gegeben. Danach wurden weitere Verdünnungen in Nutrient Broth bis zu den Konzentrationen von $10^{3}, 10^{4}, 10^{5}$ und $10^{6} \mathrm{cfu} / \mathrm{ml}$ hergestellt und für den DAS-ELISA verwendet.

Die polyklonalen Antiseren wurden gemäß Herstellerempfehlung 1:1000 verdünnt. Die Farbreaktion wurde mit einem ELISA-Photometer bei einer Wellenlänge von 405 nm gemessen und mit der Extinktion der Negativkontrolle ohne Bakterien verglichen. Unter diesen Bedingungen konnten die Bakterien bei einer Konzentration von $10^{4} \mathrm{cfu} / \mathrm{ml}$ nachgewiesen werden (Abb. 1).

Abb. 1: Nachweisgrenze für $X c p$-Stamm GSPB 2503 im Pflanzenextrakt und Nutrient Broth bei 405 nm nach $2 \mathrm{~h}$

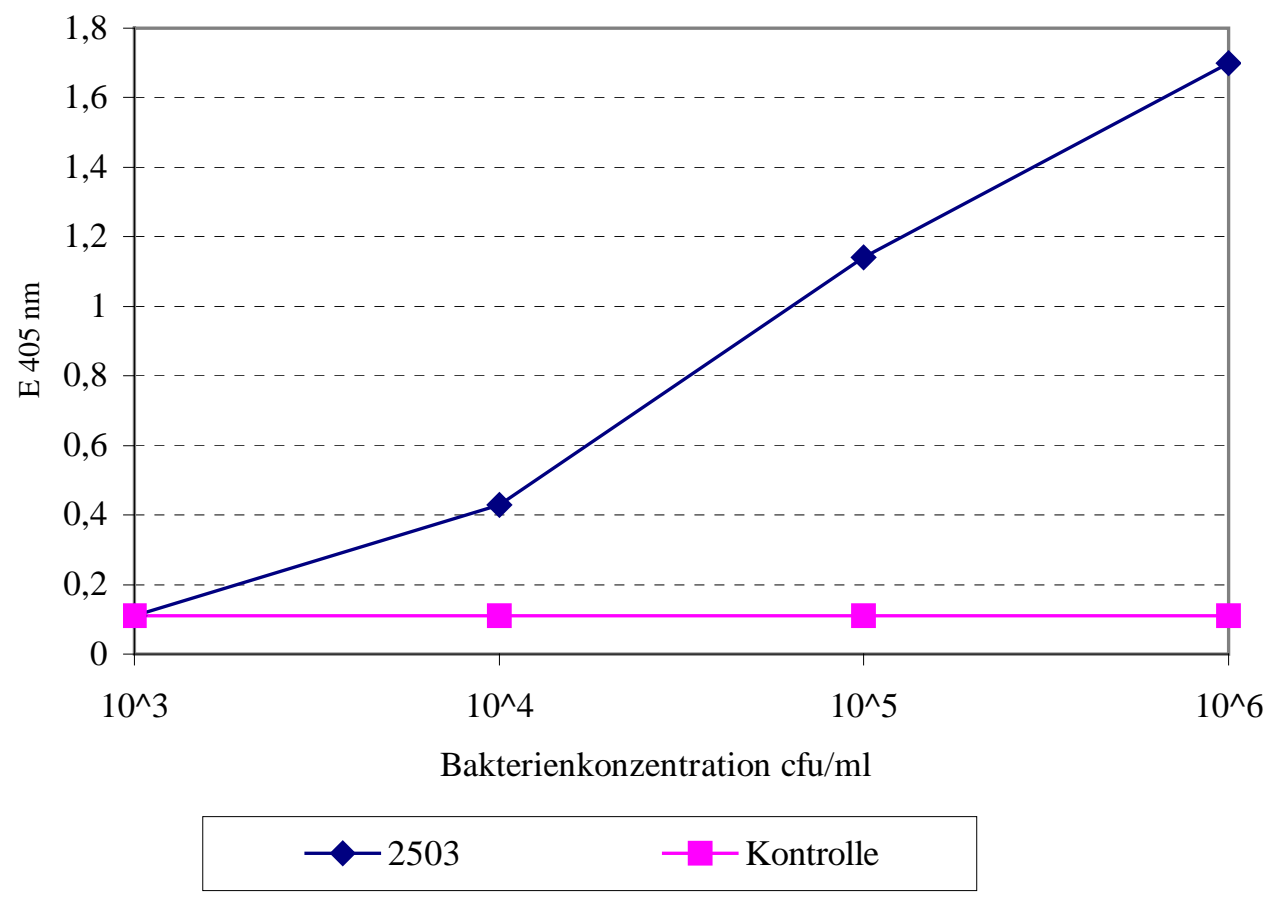




\subsubsection{Reaktion des BIOREBA-Antiserums gegenüber anderen $X c p$-Stämmen}

Nachdem die Versuche mit dem Stamm Xcp-2503 zeigten, dass sich mit dem BiorebaSerum im ELISA erst Bakteriendichten von $10^{4} \mathrm{cfu} / \mathrm{ml}$ nachweisen lassen (Abb. 1), wurden ähnliche Tests mit Xcp-Stämmen verschiedener Herkunft (GSPB Nr. 2514, 2503, 1955, 1957, 1956 und 2636) durchgeführt.

Die Bakterienstämme wurden zunächst 24 h auf NGA kultiviert. Aus den jungen Bakterienkulturen wurden Suspensionen mit $10^{3}, 10^{4}, 10^{5}$ und $10^{6} \mathrm{cfu} / \mathrm{ml}$ in Nutrient Broth hergestellt. Von jeder Konzentration wurden zwei Wiederholungen mit 0,2 ml Antigen eingesetzt.

Tab. 6: Ermittlung der Nachweisgrenze des Bioreba-Serums mit verschiedenen $X c p$ Stämmen

\begin{tabular}{l|lccc}
\hline \multirow{2}{*}{$\begin{array}{l}\text { Bakterienkonzentration } \\
\mathrm{cfu} / \mathrm{ml}\end{array}$} & \multicolumn{4}{|c}{ Extinktion mit Xcp-Isolaten } \\
\cline { 2 - 5 } & 2514 & 2503 & 1957 & 1956 \\
\hline $10^{6}$ & 4,000 & 2,104 & 1,706 & $\mathrm{n} . \mathrm{g}$ \\
$10^{5}$ & 1,794 & 1,200 & 0,742 & 1,198 \\
$10^{4}$ & 0,384 & 0,250 & 0,206 & 0,199 \\
$10^{3}$ & 0,141 & 0,115 & 0,127 & $\mathrm{n} . \mathrm{g}$ \\
\hline Kontrolle & 0,110 & 0,110 & 0,110 & 0,110 \\
\hline
\end{tabular}

Die Extinktionswerte der verschiedenen $X c p$-Stämme mit dem Bioreba-Serum variierten sehr stark (Tab. 6). Am stärksten war die Reaktion von Stamm 2514 bei allen Konzentrationen, und die niedrigsten Werte lieferte Stamm 1957. In diesen Experimenten lag die Nachweisgrenze für alle Stämme bei $10^{4} \mathrm{cfu} / \mathrm{ml}$.

Weitere Versuche wurden mit den Xcp-Stämmen 2514, 2503, 1955, 203, und 2636 durchgeführt. Auch in diesen Experimenten zeigte sich gegen Stamm 2514 die stärkste Reaktion (Abb. 2), während sich die niedrigsten Extinktionswerte mit dem Xcp-Stamm 2636 ergaben. Um die Empfindlichkeit zu verbessern, wurden sehr viele Untersuchungen durchgeführt, mit Variationen in der Blockierung (0,1\% BSA oder 3\% Magermilch), Inkubationstemperatur $\left(4^{\circ} \mathrm{C}\right.$ und $15{ }^{\circ} \mathrm{C}$ ), Inkubationsdauer oder im Extraktionspuffer, die aber alle keine niedrigeren Nachweisgrenzen brachten. Die Extinktionswerte der Negativkontrolle fielen durch ihre relativ hohen Werte auf. So wurden für $10^{3} \mathrm{cfu} / \mathrm{ml}$ eine Extinktion von ca. 
0,12 und für die Negativkontrolle 0,15 gemessen. Außerdem wurden zwischen den Wiederholungen große Abweichungen festgestellt. Das Bioreba-Serum konnte nur bei XcpStamm 2514 einen recht schwachen Nachweis auch bei $10^{3} \mathrm{cfu} / \mathrm{ml}$ liefern (Tab. 6).

Abb. 2: Empfindlichkeit verschiedener $X c p$-Stämme gegenüber dem Antiserum von BIOREBA im DAS-ELISA

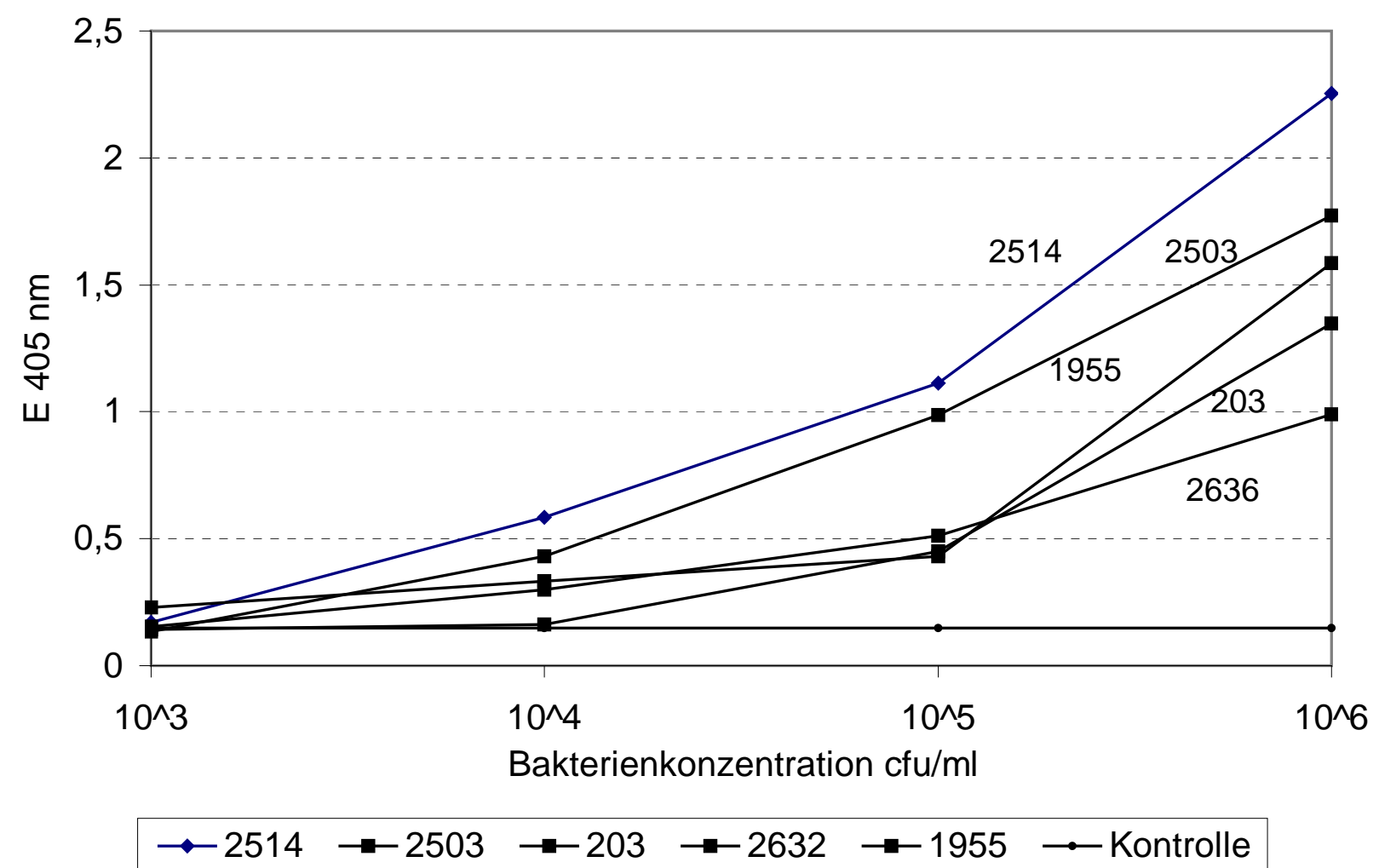

\subsubsection{Ermittlung der optimalen Antiserum- und Konjugatverdünnungen}

Von der Fa. Bioreba wurde eine Verdünnung des Serums und des Konjugates von 1:1000 zum Nachweis von $X c p$ im ELISA empfohlen. Mit diesem Titer soll die Nachweisgrenze bei $10^{3} \mathrm{cfu} / \mathrm{ml}$ liegen. In unseren Versuchen traten mit diesem Titer große Extinktionsschwankungen innerhalb der Versuchswiederholungen auf. In einigen Fällen waren die Extinktionswerte der Negativkontrolle höher als bei $10^{3} \mathrm{cfu} / \mathrm{ml}$ Bakterien. 
Abb. 3: Ermittlung der optimalen Verdünnung des BIOREBA-Antiserums mit einer Bakterienkonzentration von $10^{7} \mathrm{cfu} / \mathrm{ml}$ bei E $405 \mathrm{~nm}$ und $1 \mathrm{~h}$ Inkubation

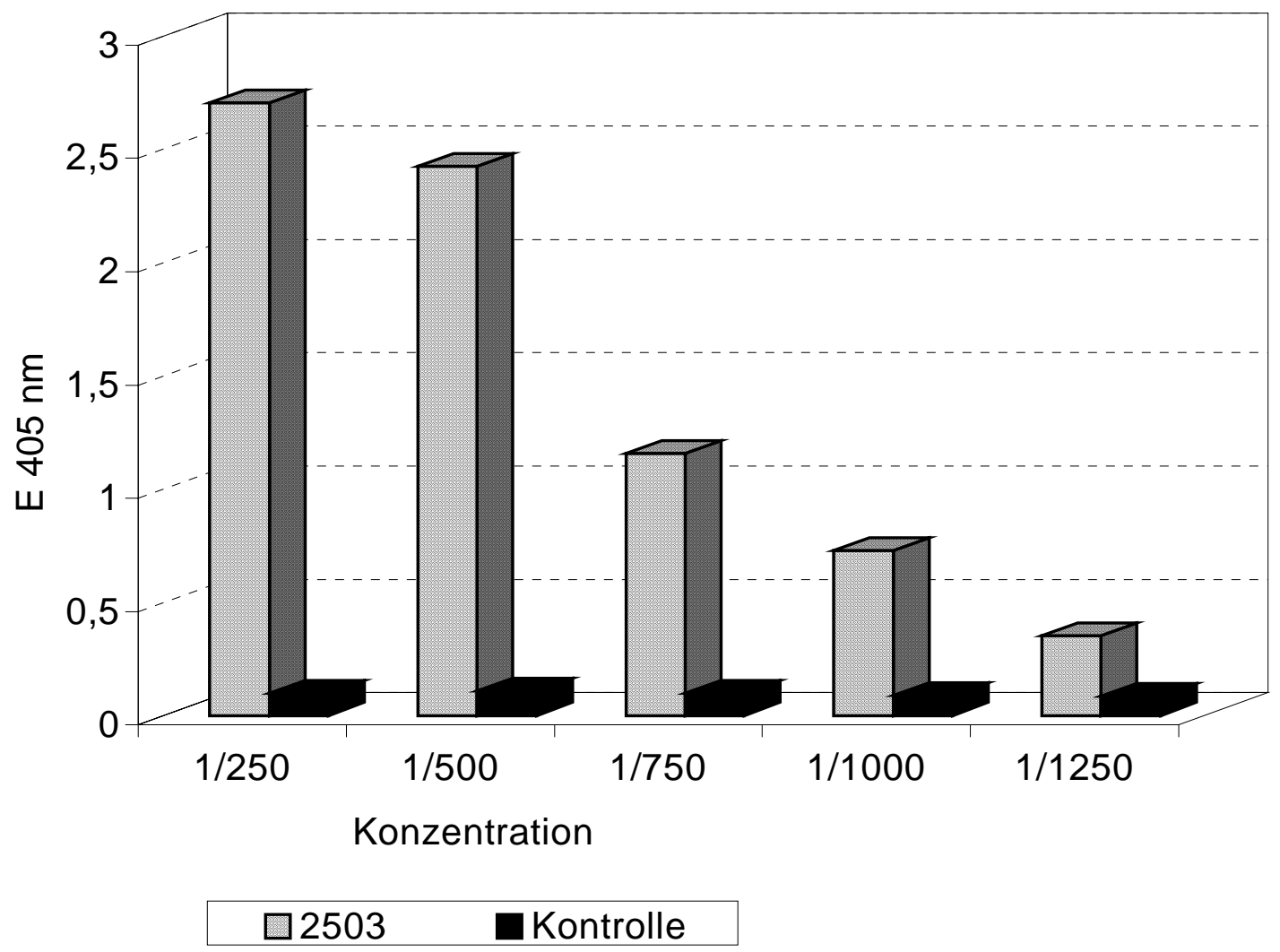

Mit ansteigender Konzentration des Antiserums (von einer Verdünnung von 1:1250 bis 1:250) zeigte sich ein kontinuierlicher Anstieg der Extinktion (Abb. 3). Um die Empfindlichkeit zu verbessern, sollte der Antikörper deswegen nur 1:250 verdünnt werden.

\subsection{Antiserum der Fa. LOEWE}

\subsubsection{Empfindlichkeit gegenüber verschiedenen $X c p$-Stämmen}

Wie durch Abb. 4 dargestellt, konnten mit dem LOEWE-Antiserum alle Xcp-Stämme bei hoher Konzentration nachgewiesen werden. Bei $10^{3} \mathrm{cfu} / \mathrm{ml}$ lagen die Extinktionswerte für die Stämme GSPB Nr. 1955 und 203 bei $\mathrm{E}_{405 \mathrm{~nm}}=0,12$ im Vergleich mit der Negativkontrolle $E_{405} \mathrm{~nm}=$ 0,09. Die anderen Xcp-Stämme GSPB Nr. 2503, 2514 und 2632 konnten bei $10^{3} \mathrm{cfu} / \mathrm{ml}$ sicher nachgewiesen werden. 
Abb. 4: Nachweisempfindlichkeit verschiedener $X c p$-Stämme gegenüber dem LOEWEAntiserum im DAS-ELISA

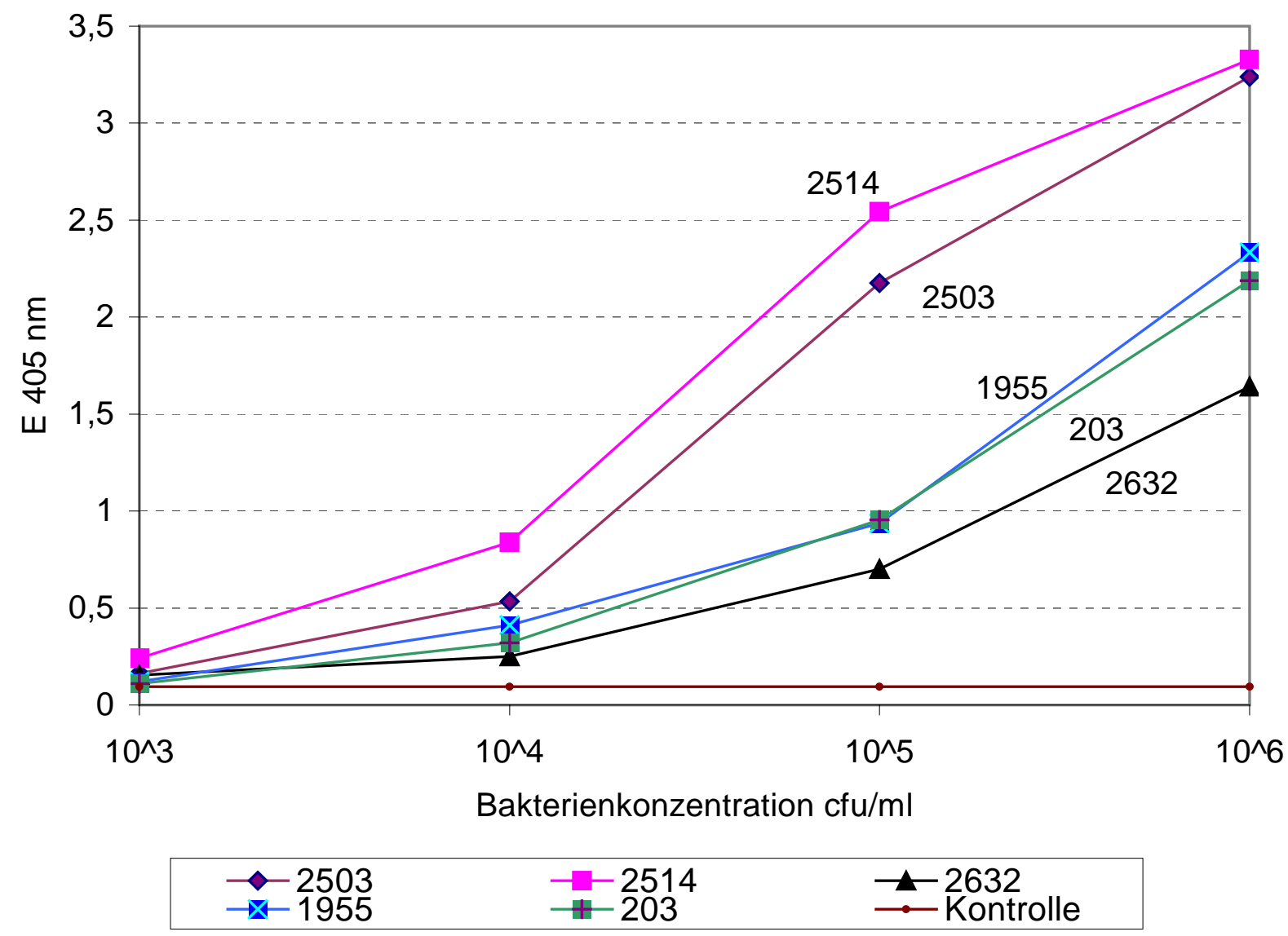

\subsubsection{Nachweisgrenze bei Mischung mit Pflanzenextrakt}

Der ELISA wurde wie unter 2.2.1.2 beschrieben durchgeführt und die Bakterien nach 2.2.1.5 angezogen. Die Proben wurden in "Pelargonienpuffer“ nach LOEWE aufgenommen. Der polyklonale Antikörper wurde wie von der Firma empfohlen, sowohl das IgG als auch das IgG-Konjugat, 1:200 verdünnt. Grundsätzlich wurde der Konjugatpuffer immer kurz vor der Anwendung frisch angesetzt.

Der "Pflanzenextrakt" wurde wie in 3.3.1 beschrieben hergestellt, aber nicht in Nutrient Broth sondern in Pelargonien-Puffer aufgenommen. 
Abb. 5: Ermittlung der Nachweisgrenze für Xcp-Stamm 2514 gemischt mit Pflanzenextrakt im "Pelargonienpuffer" bei 2 h Inkubation

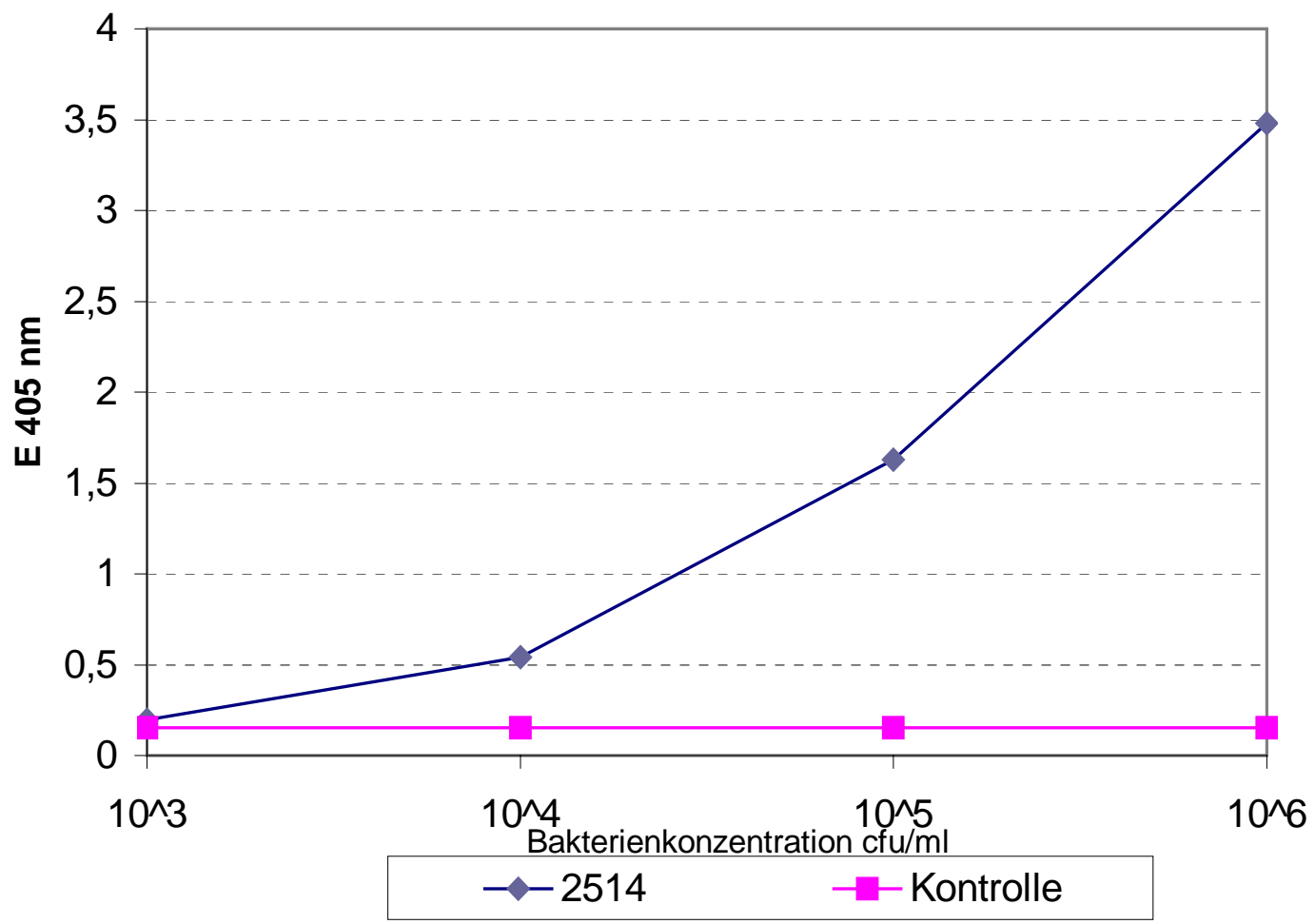

Abb. 5 lässt erkennen, dass in der Mischung von Pflanzenextrakt mit Pelargonienpuffer $10^{3} \mathrm{cfu} / \mathrm{ml}$ ganz schwach nachgewiesen wurden.

\subsection{Antiserum vom IPO}

\subsubsection{Mischung mit Pflanzenextrakt}

ELISA und Bakterienanzucht erfolgten wie unter 2.2.1.2 und 2.2.1.5 beschrieben. Die Proben wurden im Extraktionspuffer (PBS + 0,05\% Tween 20 + 1\% PVP) aufgenommen. Der polyklonale Antikörper und das IgG-Konjugat wurden, wie vom Hersteller angegeben, 1:1000 verdünnt.

Die Mischung mit Pflanzenextrakt erfolgte wie bei 3.3.1, aber mit Extraktionspuffer (PBS $+0,05 \%$ Tween $+1 \%$ PVP). 
Abb. 6: Ermittlung der Nachweisgrenze für Xcp-Stamm 2514 nach Mischung mit Pflanzenextrakt im Extraktionspuffer (PBS + 0,05\% Tween + 1\% PVP) durch das IPOAntiserum nach 2 h Inkubation

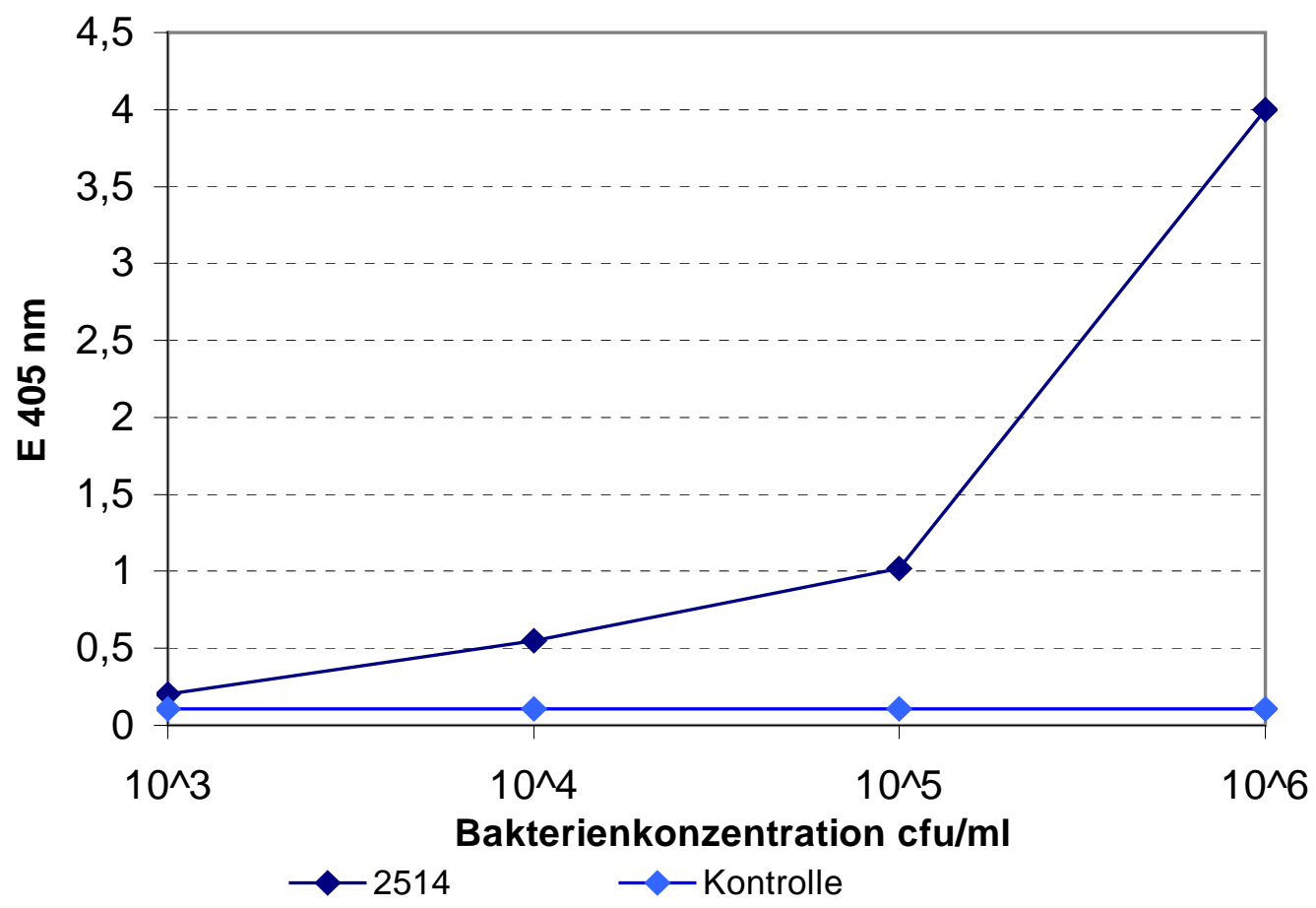

Wie aus Abb. 6 zu erkennen ist, erreichte die Nachweisgrenze mit dem IPO-Antiserum gerade noch $10^{3} \mathrm{cfu} / \mathrm{ml}$ in einer Mischung mit Pflanzenextrakt. Auf Grund der Stabilität zwischen den Konzentrationen und wegen der guten Reproduzierbarkeit wurde der IPOAntikörper für weitere Versuche verwendet.

\subsubsection{Empfindlichkeit verschiedener Xcp-Stämme im DAS-ELISA}

Im ELISA-Verfahren wurden die Xcp-Stämme GSPB Nr. 203, 2514, 1955, 2503 und 2632 mit dem ELISA-Verfahren geprüft, die 24 h auf NGA kultiviert worden waren. Durch Bestimmung der $\mathrm{OD}_{660 \mathrm{~nm}}$ wurden Bakteriensuspensionen mit $10^{3}, 10^{4}, 10^{5}$ und $10^{6} \mathrm{cfu} / \mathrm{ml}$ hergestellt. 
Abb. 7: Empfindlichkeit verschiedener $X c p$-Stämme gegenüber dem Antiserum vom IPO im DAS-ELISA nach 2 h Inkubation

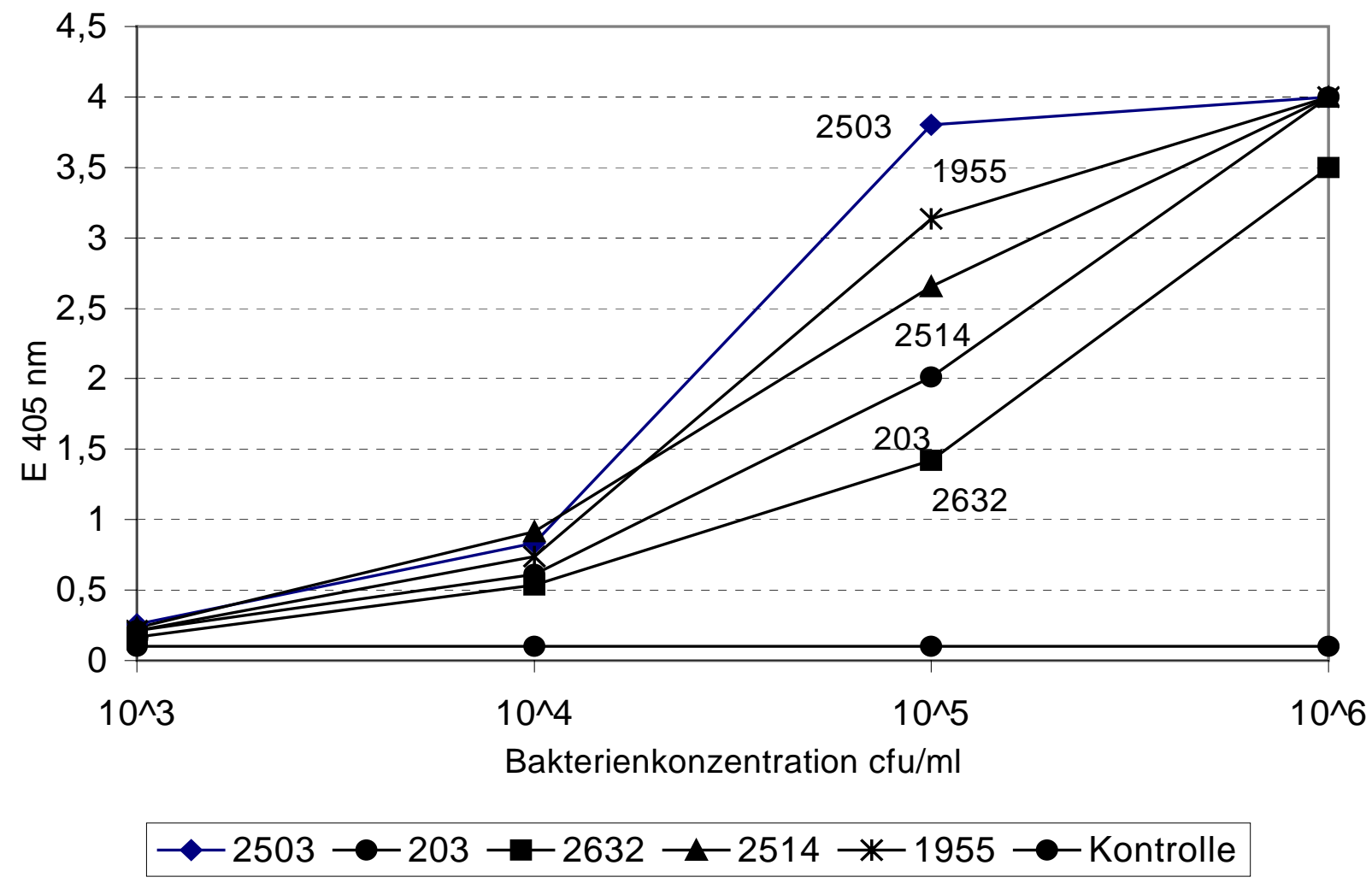

Abb. 7 zeigt, dass alle geprüften $X c p$-Stämme mit den getesteten Antiseren sicher nachgewiesen wurden. Damit ergab sich keine Stammspezifität innerhalb der Pathovarietät Xcp. Auch bei den Bakterienkonzentrationen von $10^{3} \mathrm{cfu} / \mathrm{ml}$ lagen die Extinktionswerte mit $\mathrm{E}_{405}$ $\mathrm{nm}=0,2$ noch deutlich über der Negativkontrolle mit $\mathrm{E}_{405 \mathrm{~nm}}=0,1$. D. h., unter diesen Bedingungen konnte $X c p$ bis $10^{3} \mathrm{cfu} / \mathrm{ml}$ mit dem IPO-Antiserum sicher nachgewiesen werden. Weil das IPO-Antiserum eine so hohe Empfindlichkeit gegenüber allen geprüften $X c p$-Stämmen aufwies, wurde es für alle weiteren Versuche eingesetzt.

\subsubsection{Reaktion des IPO-Antiserums gegenüber anderen phytopathogenen Bakterien}

Die immunologische Spezifität ist eine von der Struktur des Antigens abhängige Eigenschaft. Proteine sind auf Grund ihrer zahlreichen Bausteine und deren praktisch unbegrenzter Kombinationsmöglichkeiten Verbindungen von großer Vielfalt. Dies bedeutet immunologisch, dass Antikörper, die gegen ein Proteinantigen gebildet worden sind, in der Regel nur mit diesem oder strukturell sehr eng verwandten Proteinen reagieren, die der 
nur mit diesem oder strukturell sehr eng verwandten Proteinen reagieren, die der gleichen „Eiweißfamilie“ angehören (FRIEMEL, 1991). Antigene Determinanten können ihrerseits bei verschiedenen Proteinen oder Polysacchariden strukturell ähnlich oder gleich sein (z. B. Aminosäurefolgen eines Proteins, gleiche Molekülstruktur). Auf Grund dessen kann ein ursprünglich gegen eine bestimmte Antigenpräparation produziertes Antiserum mit einem anderen Antigen mit ähnlichen antigenen Determinanten kreuzreagieren. Eine solche unerwünschte Kreuzreaktion kann ein Antiserum hinsichtlich der praktischen Anwendung unbrauchbar machen.

Deswegen wurden hier Versuche mit anderen Bakterien durchgeführt, die auf Pelargonien epiphytisch vorkommen aber keine Krankheit verursachen. Es wurden Erwinia herbicola (GSPB 450), Xanthomonas zinniae (GSPB 2188) und Pseudomonas fluorescens (GSPB 1714) getestet. Erwinia herbicola und Pseudomonas fluorescens wurden auf KB-Medium 24 h kultiviert. Xanthomonas zinniae und Xanthomonas campestris pv. pelargonii wurden auf dem NGA-Medium 24 h kultiviert. Durch Bestimmung der OD $_{660 n m}$ wurden Bakteriensuspensionen im Extraktionspuffer (PBS + 0,05\% Tween + 1\% PVP) hergestellt. Von jeder Konzentration wurden zwei Kavitäten bei jeder Stufe mit 0,2 ml Antigen gefüllt. Das Ergebnis wurde photometrisch nach 1 und 2 h gemessen.

Keiner der getesteten saprophytischen Bakterienstämme zeigte im ELISA einen Wert, der über der Null-Kontrolle lag (Abb. 8). 
Abb. 8: Reaktion des IPO-Antiserums mit saprophytischen Bakterien bei einer Konzentration von $10^{5} \mathrm{cfu} / \mathrm{ml}$

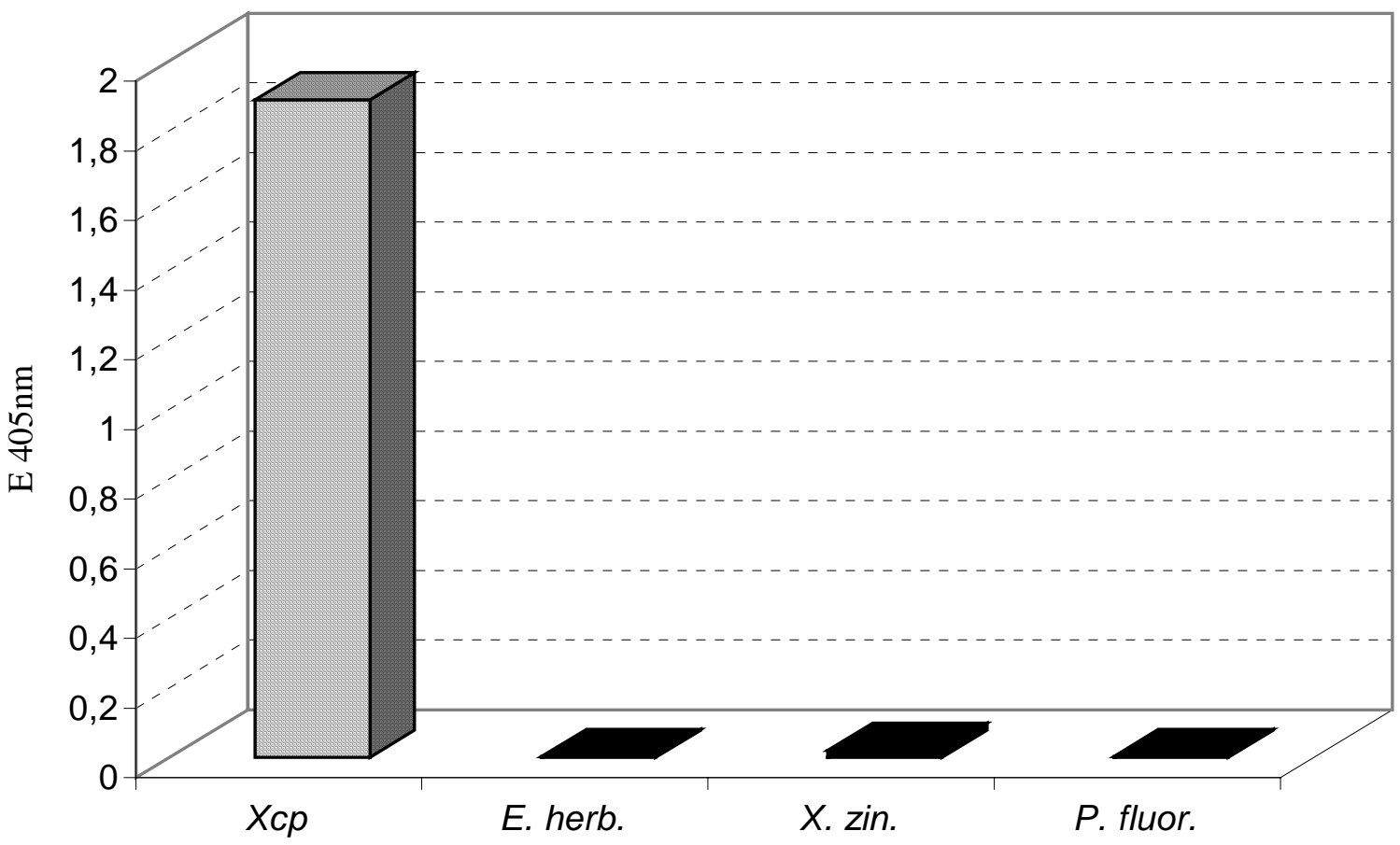

Der Antikörper (IPO) zeigte keine Kreuzreaktionen mit den geprüften saprophytischen Bakterienstämmen. Dadurch wurde eine Voraussetzung für eine einwandfreie Diagnostik erfüllt.

Die gleichen Untersuchungen wurden für BIOREBA- und LOEWE-Antiseren durchgeführt (im Ergebnis nicht dargestellt). Auch diese Antiseren zeigten keine Kreuzreaktion mit den getesteten saprophytischen Bakterien. Die poly- und monoklonalen Antiseren aus Aschersleben wurden nicht getestet.

\subsubsection{Einfluss der Probenaufarbeitung auf die Nachweisempfindlichkeit mit dem IPO-Antiserum}

Nach Auswahl des optimalen Antiserums wurden folgende weitere Versuche durchgeführt, um die Nachweisempfindlichkeit zu erhöhen. Der Xcp-Stamm GSPB Nr. 2503 wurde 24 h auf NGA-Medium kultiviert. Durch Bestimmung der OD bei $660 \mathrm{~nm}$ wurde eine Bakteriensuspension von $10^{8} \mathrm{cfu} / \mathrm{ml}$ hergestellt. Von gesunden Pelargonienpflanzen "Rosario“ 
wurde $1 \mathrm{~g}$ Stengel abgewogen, kurz in 70\% Et-OH getaucht und abgeflammt. Die Pflanzenprobe wurde in $1 \mathrm{ml}$ Bakteriensuspension von $10^{8} \mathrm{cfu} / \mathrm{ml}$ zermörsert. Die zermörserte Probe wurde mit einer sterilen Pipette in das erste Röhrchen gegeben und gut gemischt (Vortex), danach 1:10 verdünnt. Die Verdünnungsstufen $10^{3}, 10^{4}, 10^{5}$ und $10^{6} \mathrm{cfu} / \mathrm{ml}$ wurden für den ELISA verwendet. Bevor die Proben in die Platte pipettiert wurden, wurden sie für 10 min gekocht, anschließend wurde der ELISA durchgeführt (Tab. 7). Eine andere Stengelprobe wurde wie oben bearbeitet, aber anstatt zu zermörsern in $1 \mathrm{~mm}$ dünne Scheibchen geschnitten und mit Bakteriensuspension vermischt.

Tab. 7: Nachweisempfindlichkeit von $X c p$-Stamm 2503 im ELISA nach Mischen mit Scheibchen oder Homogenaten aus Pelargonienstengeln (PVP = Polyvinylpyrolidon).

\begin{tabular}{l|c|c|c|c}
\hline $\begin{array}{l}\text { Bakt. Kon- } \\
\text { zent. cfu/ml }\end{array}$ & $\begin{array}{l}\text { Pflanzen in PVP } \\
\text { zermörsert, er- } \\
\text { hitzt }\end{array}$ & $\begin{array}{l}\text { Pfl. in PVP zer- } \\
\text { mörsert, nicht er- } \\
\text { hitzt }\end{array}$ & $\begin{array}{l}\text { Pfl. in PVP } \\
\text { als Scheibchen }\end{array}$ & $\begin{array}{l}\text { Pfl. in NB-Lös. } \\
\text { als Scheibchen }\end{array}$ \\
\hline \hline $10^{6}$ & 4,000 & 4,000 & 4,000 & 1,051 \\
$10^{5}$ & 1,664 & 2,238 & 2,356 & 0,232 \\
$10^{4}$ & 0,678 & 0,609 & 0,509 & 0,125 \\
$10^{3}$ & 0,200 & 0,148 & 0,149 & 0,100 \\
\hline Pos. Kontr. & $4,000\left(10^{6}\right)$ & $4,000\left(10^{6}\right)$ & $4,000\left(10^{6}\right)$ & $4,000\left(10^{6}\right)$ \\
Neg. Kontr. & 0,102 & 0,114 & 0,100 & 0,103 \\
\hline
\end{tabular}

In den höheren Verdünnungsstufen zeigten die Pflanzenproben, die in dem PVP-Puffer zermörsert und dann erhitzt wurden, etwas höhere Extinktionswerte als die nicht erhitzten (Tab. 7). Bei der Variante 1 (Pflanzen zermörsert, erhitzt) lag die Nachweisempfindlichkeit bei $10^{3} \mathrm{cfu} / \mathrm{ml}$. Die Pflanzenproben aus Scheibchen ergaben bei der Verdünnung $10^{4}$ niedrigere Extinktionswerte. Am schlechtesten waren die Ergebnisse, wenn die Scheibchen in NB-Lösung aufgenommen wurden. 


\subsubsection{Einsatz des DAS-ELISA zum Nachweis von $X c p$ in latent infizierten Pelargo- nienpflanzen mit dem IPO-Antiserum}

Nachdem sichergestellt war, dass nach der Optimierung des ELISA der Krankheitserreger spezifisch und mit hoher Empfindlichkeit nachgewiesen werden konnte, konzentrierten sich die weiteren ELISA-Untersuchungen auf latent infizierte Pflanzen.

Für diesen Versuch wurden Pelargonienpflanzen der Sorte "Rosario“ und "Isabell" eingesetzt, die vor 33 Monaten am Stengel künstlich inokuliert worden waren (siehe Kapitel I). Die Pflanzen von "Rosario“ zeigten deutliche Krankheitssymptome, dagegen die von "Isabell“ nicht. In allen Pflanzenproben wurde der Bakteriengehalt gleichzeitig mikrobiologisch mit dem semiselektiven Medium bestimmt. Die Pelargonienstengel wurden in dünne Scheiben geschnitten, 5 min geschüttelt und der Überstand als Probe verwendet.

In allen Proben von "Rosario“ konnten die Bakterien mit dem ELISA nachgewiesen werden (Tab. 8 und Abb. 9). Bei dem niedrigsten ELISA-Wert (Probe Rosario 1) wurden im mikrobiologischen Test keine Bakterien gefunden, wahrscheinlich weil durch den ELISA nur noch tote Bakterien erfasst wurden (Tab. 8).

Andererseits wurden in den Proben von Isabell (Isabell 1 und Isabell 2) mit dem ELISA nie Bakterien nachgewiesen, obwohl nach der mikrobiologischen Methode in Isabell 1,9 x $10^{2} \mathrm{cfu} / \mathrm{g}$ im Stengel gefunden wurden. Die hohen Extinktionswerte von 4.000 für die Positivkontrolle, d. h. gesunde Pelargonienstengel gemischt mit $10^{6} \mathrm{cfu} / \mathrm{ml}$, im Vergleich mit einer Extinktion von nur 0,5785 für $10^{6} \mathrm{cfu} / \mathrm{ml}$ Pflanzenextrakt (hergestellt aus alten Pelargonienstengeln, die latent infiziert waren) zeigen, dass die Nachweisempfindlichkeit durch Substanzen aus den recht alten Pelargonienstengeln sehr beeinträchtigt wurde. 
Tab. 8: Nachweis von $X c p$ in Pelargonienpflanzen 33 Monate nach Inokulation, Vergleich von ELISA und mikrobiologischem Verfahren

\begin{tabular}{l|c|c}
\hline Proben Nr. & ELISA-Mittelwert & Ausplattierung cfu/ml \\
\hline \hline Rosario 1 & 0,4995 & nicht gefunden \\
Rosario 2 & 0,5785 & $6,5 \times 10^{6}$ \\
Rosario 3 & 1,3605 & $4,4 \times 10^{7}$ \\
Rosario 4 & 1,332 & $4,0 \times 10^{7}$ \\
Isabell 1 & 0,1615 & $1,9 \times 10^{2}$ \\
Isabell 2 & 0,1275 & nicht gefunden \\
\hline Gesunde Kontrolle & 0,128 & \\
Positiv-Kontrolle $\left(10^{6} \mathrm{cfu} / \mathrm{ml}\right)$ & 4,000 & \\
\hline
\end{tabular}

Abb. 9: Nachweis von $X c p$ in Pelargonienpflanzen mit dem ELISA-Verfahren, 33 Monate nach der Inokulation, E 405 nm und 3 h Inkubation

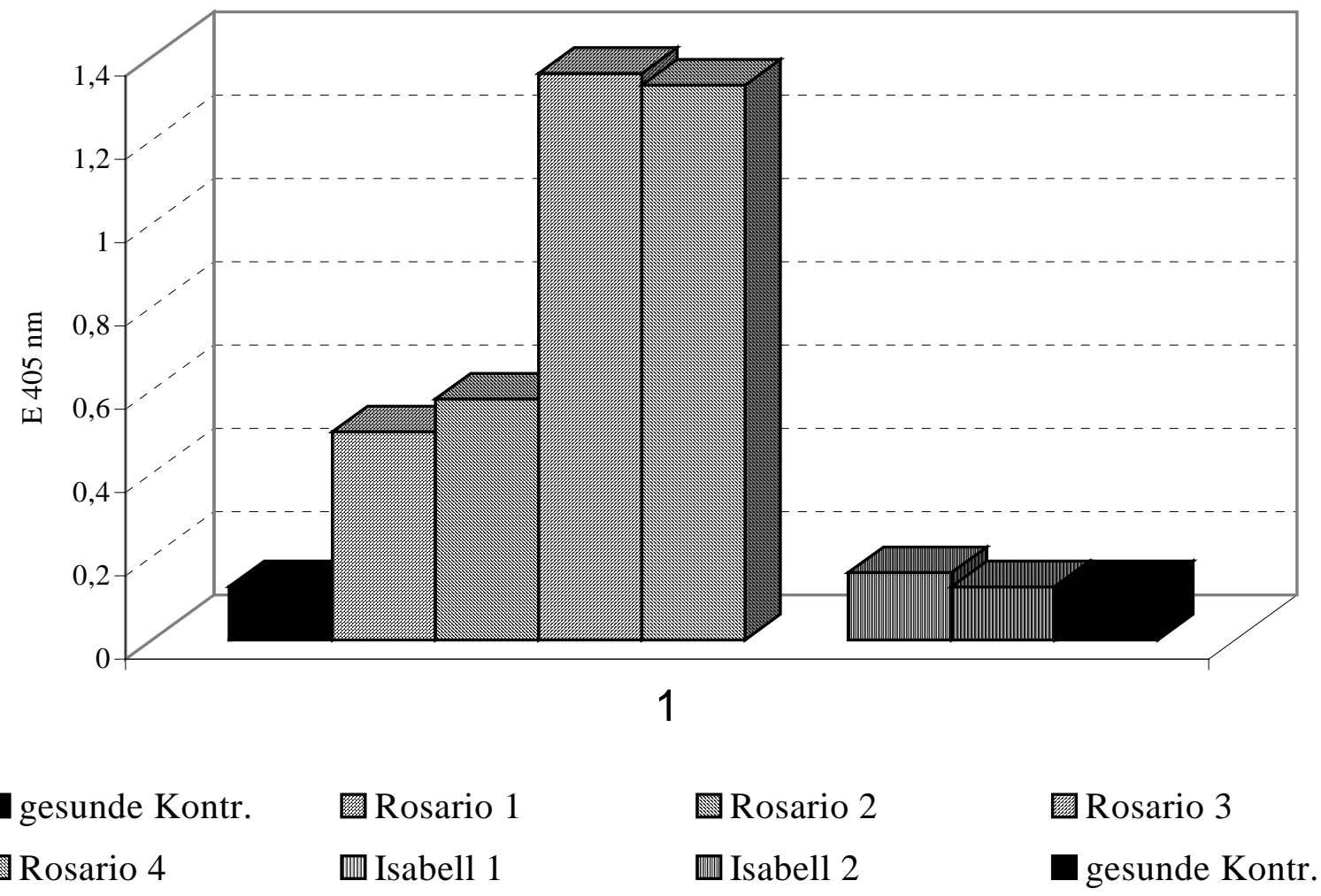




\subsubsection{Nachweis von $X c p$ in Pelargonienpflanzen mit dem DAS-ELISA 4 Jahre nach Inokulation}

Für diesen Versuch wurden die Pelargonienpflanzen "Rosario“ und "Isabell“ eingesetzt, die vor 4 Jahren inokuliert worden waren (Kapitel I, 2.9). Die Pflanzen "Rosario“, $10^{4}$ (15 $\left.{ }^{\circ} \mathrm{C}\right)$ zeigten leichte Krankheitssymptome, dagegen die von “Isabell“, $10^{4}\left(15^{\circ} \mathrm{C}\right)$ nicht. Bei "Rosario“ wurden Proben von unterschiedlichen Orten genommen, allerdings war der Inokulationspunkt eingetrocknet. Bei “Isabell“ wurden der Inokulationspunkt und jeweils eine Probe 1,5 cm über und unter dem Inokulationspunkt untersucht. In allen Proben wurde der Bakteriengehalt gleichzeitig mikrobiologisch mit dem NGA- und NGAR-Medium bestimmt. Die Pelargonienstengel wurden im Extraktionspuffer (PBS + 0,05 Tween $20+1 \%$ PVP) zermörsert und jeweils eine Probe auf 0,1 ml NGAR- und NGA-Medium ausplattiert. Von den Resten wurden Verdünnungsreihen hergestellt. Die Verdünnungsreihen wurden für 10 min gekocht. Dann wurden davon jeweils 0,2 ml für das ELISA-Verfahren verwendet.

Wie in Abb. 10 dargestellt, wurde $X c p$ sowohl bei "Rosario" als auch bei "Isabell“ mit dem ELISA-Verfahren nachgewiesen. Durch das mikrobiologische Verfahren wurden bei "Rosario“ Probe $11,9 \times 10^{7} \mathrm{cfu} / \mathrm{g}$ und bei "Rosario“ Probe $22,9 \times 10^{3} \mathrm{cfu} / \mathrm{g}$ gefunden. In den Proben von "Isabell“ (Probe $14,2 \times 10^{5} \mathrm{cfu} / \mathrm{g}$ ) und "Isabell“ (Probe $21 \times 10^{4} \mathrm{cfu} / \mathrm{g}$ ) konnte mit dem ELISA-Verfahren Xcp nachgewiesen werden. Allerdings konnten bei "Isabell“ (Probe 3) mit dem mikrobiologischen Test und bei "Rosario“ (Probe 3) mit dem ELISA $X c p$ nicht gefunden werden.

Tab. 9: Nachweis $X c p$ in Pelargonienpflanzen 4 Jahre nach Inokulation mit dem ELISA und mikrobiologischen Verfahren

\begin{tabular}{l|c|c}
\hline Proben Nr. & ELISA-Mittelwert & Ausplattierung cfu/ml \\
\hline \hline Rosario 1 & 4,000 & $1,9 \times 10^{7}$ \\
\hline Rosario 2 & 0,1975 & $2,9 \times 10^{3}$ \\
\hline Rosario 3 & 0,1095 & $1,2 \times 10^{2}$ \\
\hline Isabell 1 & 0,756 & $1,2 \times 10^{5}$ \\
\hline Isabell 2 & 0,526 & Nicht gefunden \\
\hline Isabell 3 & 0,2235 & \\
\hline Gesunde Kontrolle & 0,150 & \\
Positiv-Kontrolle $\left(10^{6}\right)$ & 3,689 & \\
\hline
\end{tabular}


Abb. 10: Nachweis von $X c p$ in Pelargonienpflanzen mit dem ELISA-Verfahren 4 Jahre nach der Inokulation, bei E 405 nm und 3 h Inkubation

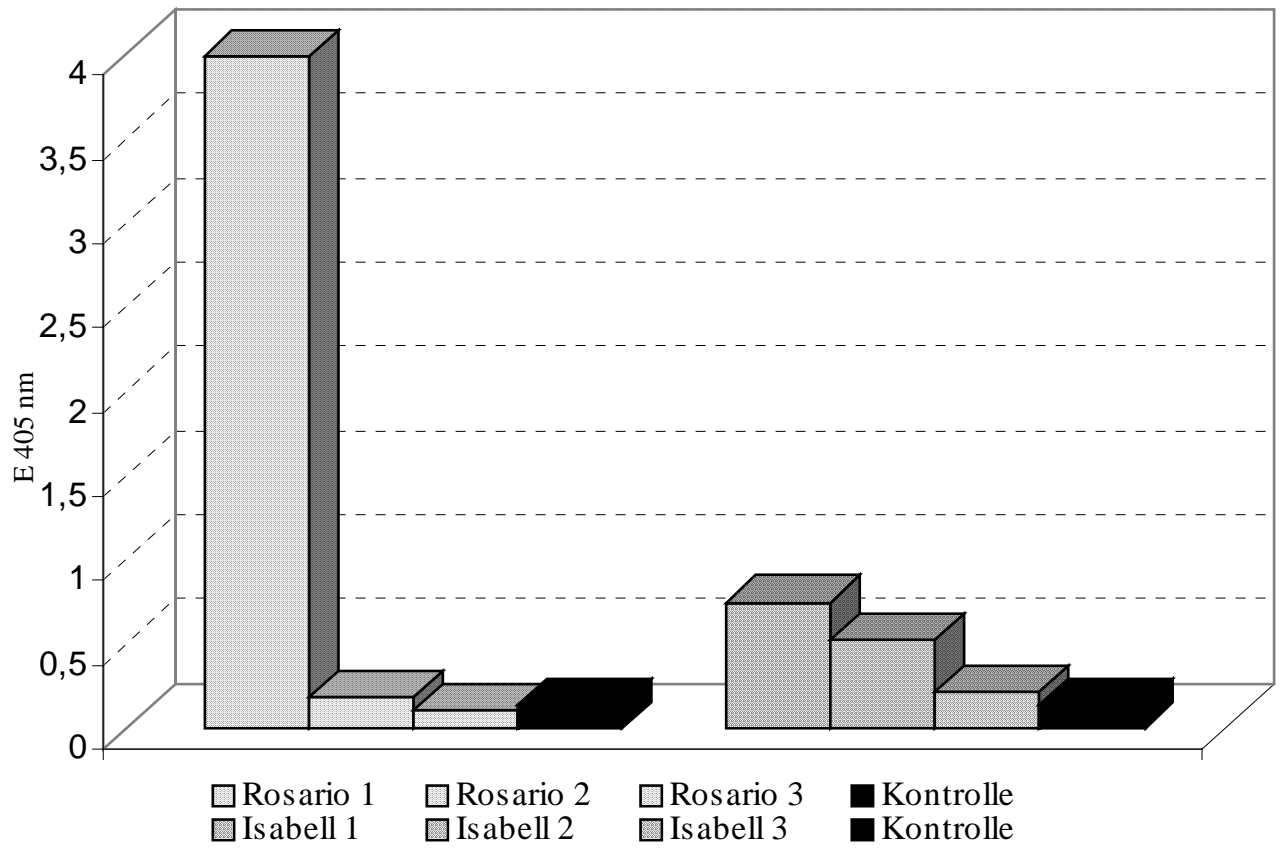

\subsubsection{Nachweis von Xanthomonas campestris pv. pelargonii mit dem IPO-Antiserum nach einer Zwischenvermehrung}

Die bisherigen Versuche ergaben für das IPO-Antiserum (1:1000) die höchste Sensitivität $\left(10^{3} \mathrm{cfu} / \mathrm{ml}\right)$ (Tab. 7 und 10), die jedoch immer noch geringer war als bei der mikrobiologischen Untersuchung $\left(10^{2} \mathrm{cfu} / \mathrm{ml}\right)$. Die Nachweisempfindlichkeit sollte nun durch eine Zwischenvermehrung weiter verbessert werden. Der ELISA wurde wie unter 3.7 beschrieben durchgeführt.

Mit einer frischen Bakterienkultur wurde eine Verdünnungsreihe von $10^{6}-10^{2} \mathrm{cfu} / \mathrm{ml}$ in Tween-Cellobiose-Lösung hergestellt. Zu jeder Konzentration wurden 0,5 g gesunder Pelargonienstengel als Scheibchen hinzugefügt und bei $26^{\circ} \mathrm{C}$ und 110 UPM 20 - 24 h inkubiert. Danach wurden die Proben für 10 min kurz gekocht und mit den Überständen der ELISA-Test durchgeführt. Ähnliche Versuche wurden von ELPHINSTONE et al. (1996) für den Nachweis von Ralstonia solanacearum in latent befallenen Kartoffelknollen durchgeführt. Von diesen Autoren wurden die Proben in einer semiselektiven SMSANährlösung (siehe Kapitel IV) bei $28{ }^{\circ} \mathrm{C} 48 \mathrm{~h}$ zwischenvermehrt und anschließend mit ELISA und PCR untersucht. Die Proben wurden für 4 min gekocht, um die Pflanzenenzyme zu inaktivieren. 
Abb. 11: Nachweis von $X c p$ im Überstand von Tween-Cellobiose Nährlösung nach 20 -24 h Inkubation mit Pelargonienscheibchen mit dem ELISA-Verfahren, bei 405 nm nach 2 h Inkubation

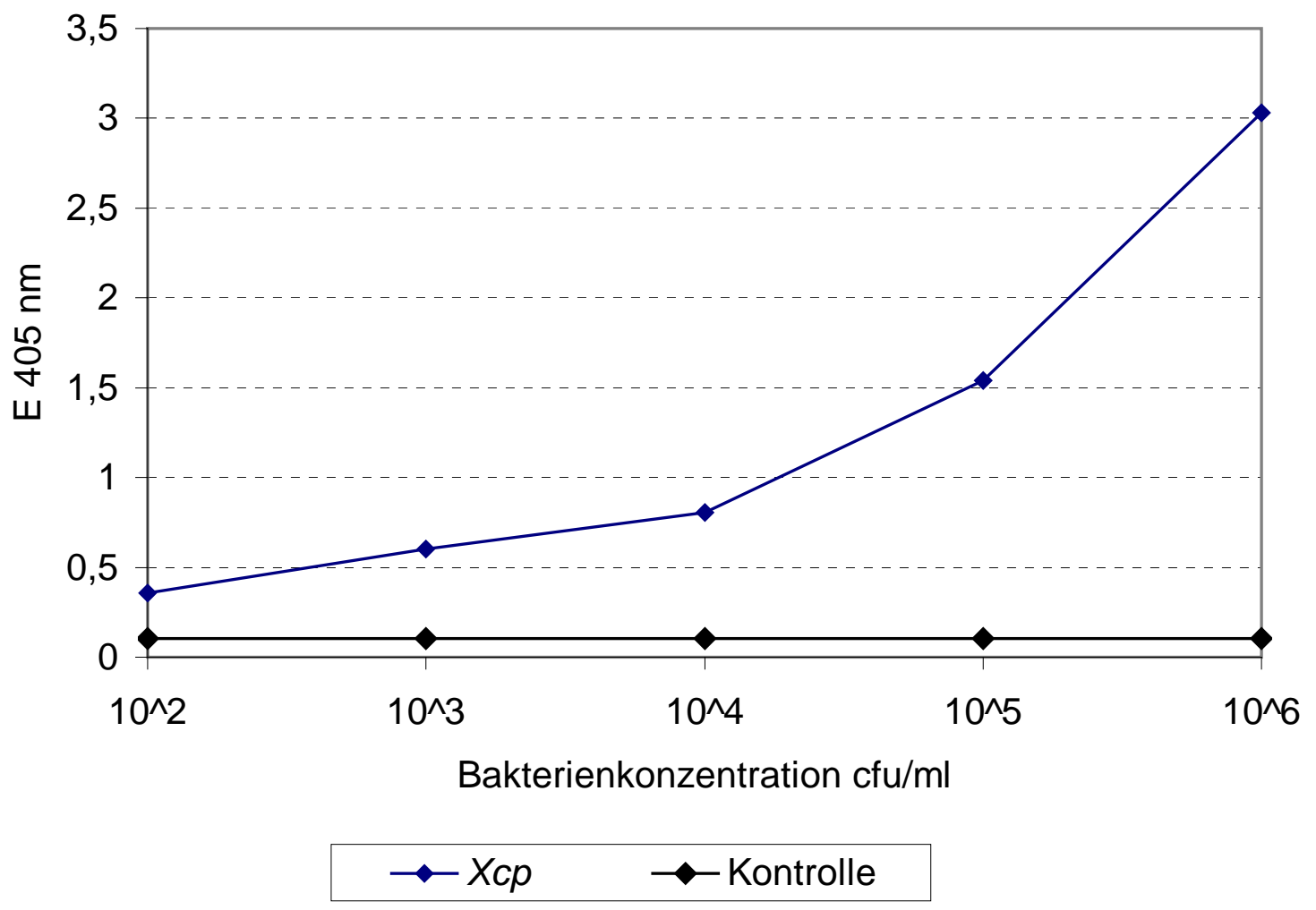

Wie Abb. 11 zeigt, konnte durch Zwischenvermehrung und Erhitzen der Proben sowie durch Verlängerung der Konjugatinkubation (4,5 h statt 4 h, siehe 2.2.1.2) die Nachweisempfindlichkeit wesentlich verbessert werden. Sogar eine ursprüngliche Konzentration von nur $10^{2} \mathrm{cfu} / \mathrm{ml}$ in der Einweichlösung der Pelargonienstengel wurde noch detektiert, ohne dass aus dem Pflanzenmaterial eventuell herausdiffundierte Substanzen die Bakterien hemmten.

\subsection{Vergleich der Antiseren zum Nachweis von $X c p$-Reinkulturen}

Alle Antiseren wurden jeweils parallel auf einer Mikrotiterplatte unter den gleichen Bedingungen geprüft. Der ELISA wurde wie unter 2.2.1.2 und 2.2.1.3 durchgeführt. Die Bakterien wurden wie unter 2.2.1.5 beschrieben angezogen, und die Proben wurden je nach Antiseren in Proben-Puffer verdünnt. 
Tab. 10: Nachweisgrenze für Xathomonas campestris pv. pelargonii mit den Stämmen 2514 und 2503 in Reinkulturen (tabellarisch und graphisch dargestellt)

\begin{tabular}{|c|c|c|c|c|c|c|c|}
\hline $\begin{array}{l}\text { Bakt.- } \\
\text { Konz. }\end{array}$ & \multicolumn{3}{|c|}{ Extinktion mit $Х с p$ Stamm 2514} & \multicolumn{4}{|c|}{ Extinktion mit Xcp Stamm 2503} \\
\hline $10^{6}$ & 4,000 & 3,327 & 1,768 & 4,000 & 3,239 & 1,697 & 0,115 \\
\hline $10^{5}$ & 4,000 & 3,194 & 1,112 & 4,000 & 2,202 & 1,142 & 0,114 \\
\hline $10^{4}$ & 3,273 & 0,839 & 0,584 & 2,937 & 0,535 & 0,429 & 0,100 \\
\hline $10^{3}$ & 0,663 & 0,242 & 0,170 & 0,504 & 0,162 & 0,107 & 0,100 \\
\hline Kontrolle & 0,116 & 0,094 & 0,10 & 0,078 & 0,094 & 0,106 & 0,101 \\
\hline
\end{tabular}

Abb. 12a: Vergleich von Antiseren zum Nachweisgrenze von Xcp-Stamm 2503 im ELISA-Verfahren

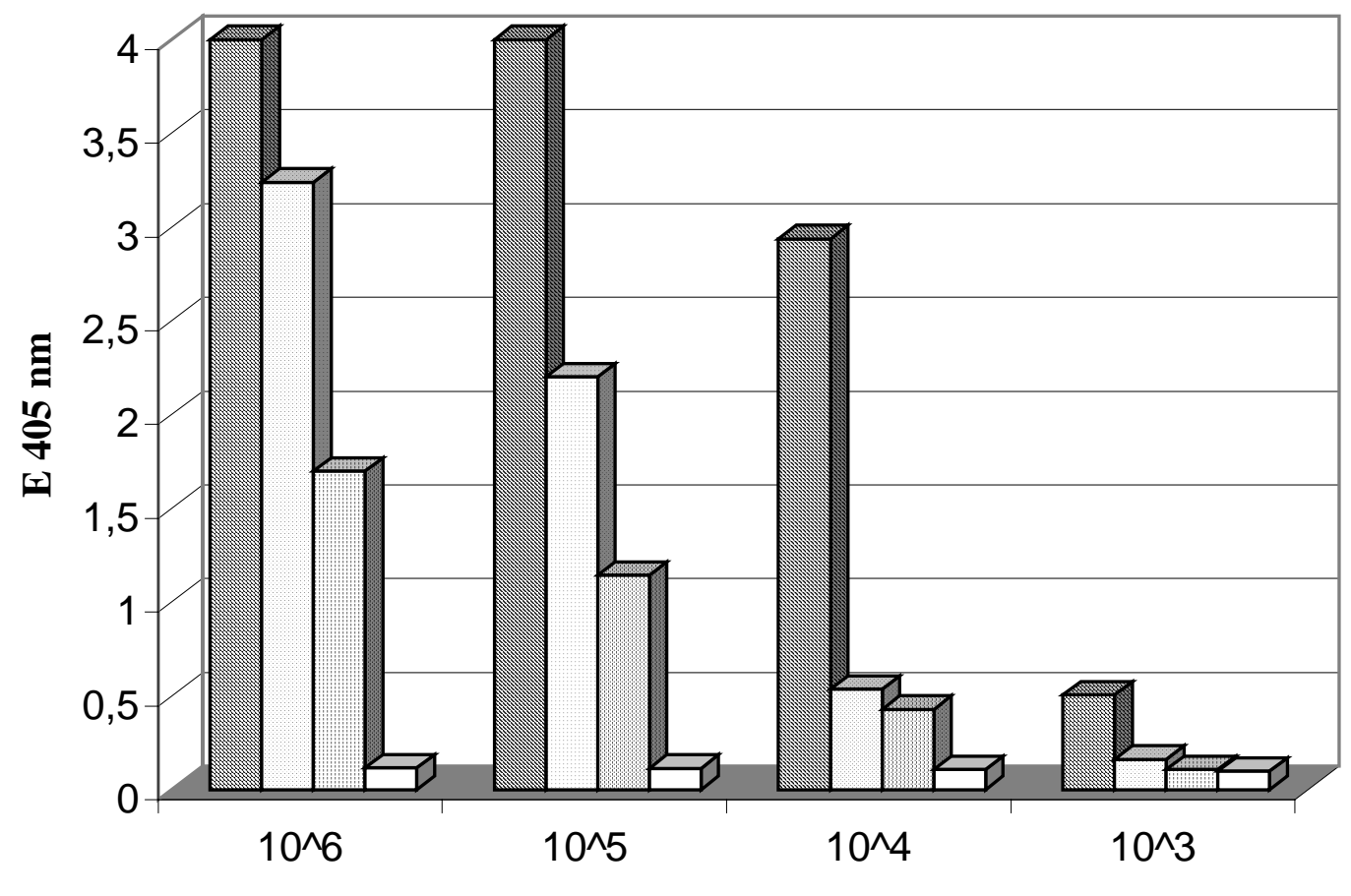

Bakterienkonzentration $\mathbf{c f u} / \mathrm{ml}$

$\square$ IPO $\square$ Loewe $\square$ Bioreba $\square$ Aschersleben


Abb. 12b: Vergleich von Antiseren zur Nachweisgrenze von Xcp-Stamm 2514 im ELISAVerfahren

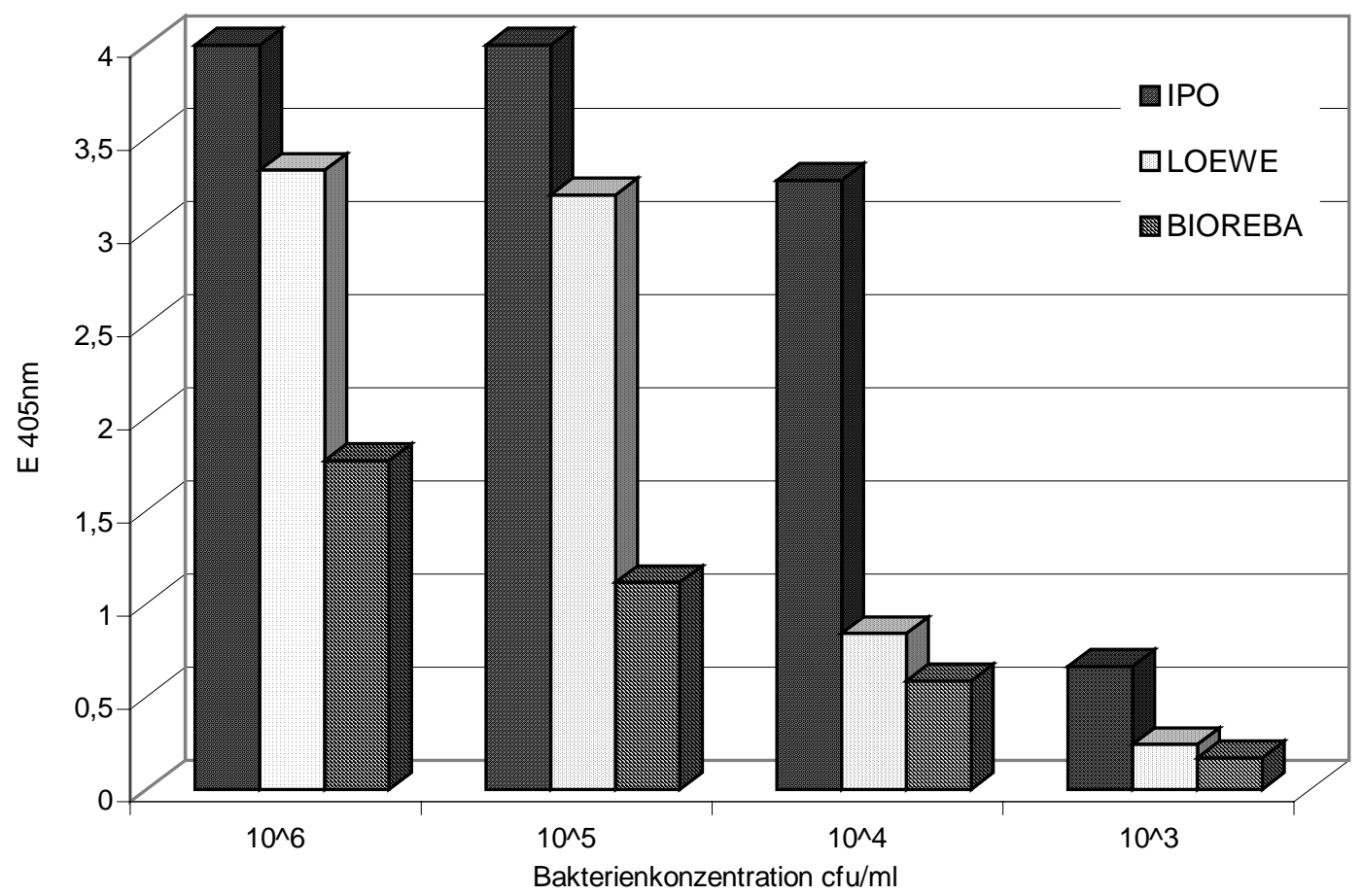

Wie aus der Tab. 10 und den Abb. 12a und 12b hervorgeht, lag unter gleichen Testbedingungen die Nachweisgrenze für eine Reinkultur in PBS + Tween + PVP mit dem IPOAntiserum und in Tris-Puffer mit dem LOEWE-Antiserum bei $10^{3} \mathrm{cfu} / \mathrm{ml}$. Für das Antiserum der BIOREBA lag die Nachweisgrenze für den Xcp-Stamm 2514 bei $10^{3} \mathrm{cfu} / \mathrm{ml}$ und für den Stamm 2503 bei $10^{4} \mathrm{cfu} / \mathrm{ml}$. Mit dem polykolonalen Antiserum aus Aschersleben (nur in Abb. 12a enthalten) konnte $X c p$ nicht nachgewiesen werden.

Auf Grund der hohen Empfindlichkeit wurde im Folgenden nur das IPO-Antiserum verwendet. Als Alternative kann das Antiserum der Fa. LOEWE empfohlen werden.

\subsection{Protokoll für den ELISA zum Nachweis von Xanthomonas campestris pv. pe-} largonii in latent befallenen Pelargonienpflanzen mit dem IPO-Antiserum

Aus den bisherigen Untersuchungen ergab sich das nachstehend beschriebene Protokoll.

1. Beschichtung der Mikrotiterplatten mit dem Antikörper (IPO, Wageningen), 1:1000 verdünnt, $4 \mathrm{~h}$ bei $37^{\circ} \mathrm{C}$ inkubieren 
2. Zugabe der Probe (nach Zwischenvermehrung in T+C-Lösung 20 - 24 h und 10 min kochen), $19 \mathrm{~h}$ bei $4{ }^{\circ} \mathrm{C}$ inkubieren

3. Zugabe des mit alkalischer Phosphatase konjugierten Antikörpers

1:1000 verdünnt, $4,5 \mathrm{~h}$ bei $37^{\circ} \mathrm{C}$ inkubieren

4. Zugabe von p-Nitrophenylphosphat (Enzymsubstrat),

$1 \mathrm{mg} / \mathrm{ml}$ in Substratpuffer, 1 bis $2 \mathrm{~h}$ im Dunkeln bei $20^{\circ} \mathrm{C}$ inkubieren,

Messung im Photometer bei 405 nm

Die ELISA-Platten wurden zwischen den einzelnen Schritten dreimal je drei Minuten mit Waschpuffer gewaschen.

\subsection{Fluoreszenzmikroskopische Untersuchungen}

Neben dem quantitativen und spezifischen Nachweis der Erreger in der Pelargonienpflanze bieten immunologische Methoden auch die Möglichkeit, Pathogene direkt in der Pflanze zu lokalisieren oder im Substrat nachzuweisen. Hierzu eignet sich insbesondere die Immunfluoreszenz.

\subsubsection{Nachweis von $X c p$ mit Immuno-Fluoreszenz-Farbstoff}

Bei der Immunfluoreszenz werden die Antikörper an einen Fluoreszenzfarbstoff gekoppelt. Nach Anregung mit UV-Licht (400-550 nm) emittieren diese Farbstoffe Licht bestimmter längerer Wellenlängen, so dass angefärbte Zellen charakteristisch leuchten.

In den folgenden Versuchen wurden die Antikörper gegen $X c p$ nicht direkt mit Fluoreszenzfarbstoff markiert, sondern ein käuflicher, gegen Kaninchen-AK gerichteter Sekundärantikörper verwendet, der an den Fluoreszenzfarbstoff FITC gekoppelt war.

\subsubsection{Fluoreszenzmikroskopischer Nachweis von Xcp in Suspension}

Um die vorhandenen Antiseren für diese Zwecke zu testen, wurden zunächst die Bakterien aus einer Suspension mit $10^{2}-10^{6} \mathrm{cfu} / \mathrm{ml}$ nach einer Methode von DeBOER (1990) angefärbt und im Auflicht-Fluoreszenzmikroskop untersucht.

Die mit FITC angefärbten Bakterien in der Suspension konnten durch charakteristisches Leuchten im Dunkelfeld deutlich erkannt werden. Abb. 13 zeigt mit den Farbstoff markierte Bakterien bei 400-facher Vergrößerung. 


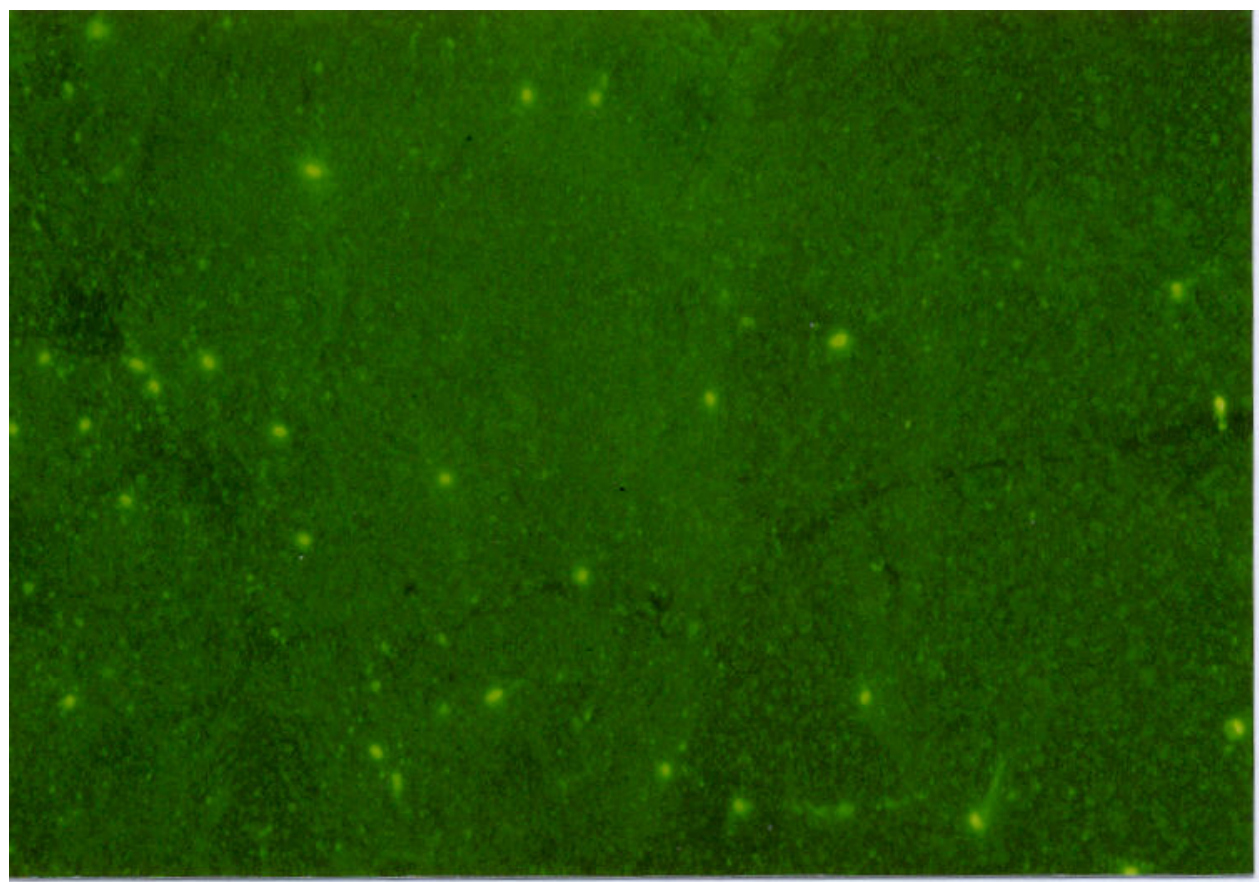

Abb. 13: Mit FITC gefärbte Xcp-Bakterienzellen

Als Negativ-Kontrolle wurden $X c p$-Bakterien nur mit FITC-Konjugat inkubiert. Es konnte keine Fluoreszenz festgestellt werden. Die Nachweisempfindlichkeit durch ImmunoFluoreszenz betrug $10^{2} \mathrm{cfu} / \mathrm{ml}$ in $X c p$-Reinkulturen.

\subsubsection{Fluoreszenzmikroskopischer Nachweis von $X c p$ in latent befallenen Pflanzen}

Es sollte festgestellt werden, ob das für reine Bakteriensuspensionen entwickelte Verfahren auch für den Nachweis von latent befallenen Pflanzen einsetzbar war.

Für diesen Versuch wurden Pelargonienpflanzen der Sorte "Rosario“ eingesetzt, die vor 33 Monaten am Stengel künstlich inokuliert worden waren. Die Pflanzen zeigten deutliche Symptome. Die Pelargonienstengel wurden in dünne Scheibchen geschnitten oder homogenisiert und 5 min geschüttelt. Der Überstand wurde als Probe verwendet.

Die Autofluoreszenz maskierte die echte Fluoreszenz. Deswegen konnten die Xcp-Zellen nicht sicher nachgewiesen werden, obwohl dieselbe Probe mit dem ELISA und mikrobiologisch positiv reagierte. Weitere Versuche zur Verbesserung der Methode, z. B. Zusätze zum Aufhellen des Hintergrundes, waren bisher erfolglos. 


\section{DISKUSSION}

Das ELISA-Verfahren (enzyme-linked immunosorbent assay) wurde 1971 zum ersten Mal in der Humanmedizin beschrieben (ENGVALI \& PERLMANN, 1971 und 1972). Immunologische Nachweismethoden haben in den letzten Jahren auch im Pflanzenschutz zur Diagnose von pilzlichen und bakteriellen Krankheitserregern immer mehr an Bedeutung gewonnen. Nachdem CLARK \& ADAMS (1977) den ELISA in der Pflanzenvirologie einführten, wurden serologische Techniken erfolgreich für die Diagnose pathogener Viren eingesetzt. Seit Ende der 70er Jahre wurden zahlreiche ELISA-Tests auch für den Nachweis von Pilzen und Bakterien in der Pflanze erarbeitet.

Ein Nachteil des ELISA ist, dass falsch-positive Reaktionen mit anderen Organismen und Substanzen auftreten können (NAMETH et al., 1999), und dass auch abgetötetes und damit irrelevantes antigenes Material detektiert wird. Der ELISA bietet jedoch gegenüber klassischen immunologischen Methoden, wie z. B. der Immunopräzipitation, den großen Vorteil, dass er bedeutend empfindlicher ist und mit ihm eine Quantifizierung der Befallsstärke im infizierten Pflanzengewebe ermöglicht wird. Er erlaubt eine schnelle Untersuchung auch großer Probenmengen und ist deshalb in Routinekontrollen inzwischen weit verbreitet.

Die wichtigste Grundlage eines ELISA ist ein geeignetes Antiserum. Um ausreichende Mengen von Antikörpern gegen ein bestimmtes Antigen zu erhalten, werden heute zwei Wege eingeschlagen:

1. Polyklonale Antikörper: Grundlage ihrer Entwicklung ist die Verwendung von inhomogenen Zellpopulationen, so dass Antikörper gegen viele Epitope (Bindungsstellen) gebildet werden.

2. Monoklonale Antikörper: Dies sind Antikörper, die aus der Nachkommenschaft einer einzigen antikörperhaltigen Zelle gebildet werden. Sie sind daher nur gegen eine einzige Antigendeterminante angelegt.

Auf Grund des hohen Interesses, besonders von Seiten der Züchter, wurden in dieser Arbeit Antiserenvergleiche mit dem ELISA-Verfahren zum Nachweis von Xcp durchgeführt. In der vorliegenden Arbeit wurden polyklonale und monoklonale Antikörper überprüft. Da die geprüften monoklonalen Antikörper für den Nachweis von $X c p$ aus Reinkulturen nicht genügend empfindlich waren, wurden die weiteren Untersuchungen nur mit polyklonalen Antikörpern durchgeführt. Außerdem ist die Spezifität von monoklonalen Antikörpern so 
hoch, dass unter Umständen verschiedene Stämme eines Pathogens immunologisch nicht mehr erkannt werden können (LIN et al., 1987; GEIDER, 1990). Allerdings wurden von BENEDICT et al. (1990) monoklonale Antikörper gegen das Lipopolysaccharid von X. c. pv. pelargonii entwickelt, die mit allen 76 getesteten Stämmen von $X c p$ positiv reagierten aber nicht mit einem einzigen Stamm einer großen Zahl anderer Xanthomonaden.

Der immunologische Nachweis ist in erster Linie von den selektiven Eigenschaften des Antiserums abhängig (GEIDER, 1990). Außerdem zeigen die auf dem Markt erhältlichen Antiseren oft Unterschiede in der Empfindlichkeit.

\subsection{Antiserenvergleich}

Nach CLARK (1981) reagiert der indirekte ELISA allgemein empfindlicher aber auch unspezifischer als der direkte ELISA. Bei der Untersuchung auf Xanthomonas campestris pv. pelargonii wird in der Regel der sogenannte DAS-ELISA (double-antibody-sandwichELISA) eingesetzt. Ein besonderes Problem der ELISA-Technik ist die Tatsache, dass die Nachweisgrenze bei $10^{3}-10^{4}$ Bakterien pro ml Pflanzensaft liegt (BERKELMANN et al., 1993; WOHANKA, 1994; BRIELMAIER-LIEBETANZ et al., 1994). In den USA wurde unter Anwendung polyklonaler Antikörper gegen Xcp eine Nachweisgrenze von $5 \times 10^{3}$ koloniebildenden Einheiten (=cfu) pro ml erreicht (TUINIER and STEPHENS, 1989). Eine latente Infektion mit geringeren Bakteriendichten blieb bei einer solchen Nachweisgrenze fast 4,5 Jahre unerkannt (BATUR-MICHAELIS et al., 1998). Andere Erfahrungen zeigten, dass trotz Sterilkultur der Sproßspitze und daraus entstandenen Pflänzchen die Mutterpflanzen nicht generell frei von Xanthomonas campestris pv. pelargonii waren (REUTER, 1983; KREBS, 1992). Bei Anwendung des ELISA-Verfahrens gibt es daher keine Garantie für eine tatsächliche Befallsfreiheit. Die Antiseren sind nicht empfindlich genug, eine minimale Bakterienkonzentration unterhalb von $10^{3} \mathrm{cfu} / \mathrm{ml}$ in der Pflanze nachzuweisen.

Trotz dieser Einschränkungen ist der ELISA zur Zeit die wichtigste Nachweismethode, wenn es um die Untersuchung großer Serien in Routineverfahren geht. Deswegen war es notwendig, auf dem Markt vorhandene Antiseren zu testen. Von den getesteten Antiseren wurden als Kriterium Sensivität (Nachweisempfindlichkeit), Spezifität und Reproduzierbarkeit überprüft. Gleichzeitig waren Kosten und Schnelligkeit wesentliche Parameter. 


\subsection{Empfindlichkeit der verwendeten Antiseren}

Die Empfindlichkeit stellt neben der Spezifität einen der wichtigsten Qualitätsparameter eines ELISA dar. Sie wird durch die untere Nachweisgrenze, d. h. die geringste Antigenkonzentration, die im gegebenen Volumen noch zuverlässig differenziert werden kann, dargestellt.

Die Empfindlichkeit der in dieser Arbeit verwendeten Antiseren war unterschiedlich. Die in der Literatur angegebene Nachweisgrenze von $10^{3}-10^{4} \mathrm{cfu} / \mathrm{ml}$ für polyklonale Antikörper konnte nicht immer erreicht werden.

Die Anwendung des monoklonalen Antiserums aus Aschersleben erwies sich wegen der niedrigen Empfindlichkeit als ungeeignet für den Nachweis von Xcp. Obwohl das Antiserum nur 1:200 verdünnt wurde, war die Nachweisgrenze nur $10^{6} \mathrm{cfu} / \mathrm{ml}$, niedrigere Konzentrationen konnten nicht mehr sicher nachgewiesen werden. Das Problem bestand darin, dass die Extinktionswerte bei der Negativkontrolle sehr hoch waren. Auch wenn die Platte mit 3\%igem Magermilchpulver inkubiert wurde, um die freien Bindungsstellen abzusättigen, betrugen die Extinktionswerte sowohl bei der Positivkontrolle $\left(10^{6} \mathrm{cfu} / \mathrm{ml}\right)$ als auch bei der Negativkontrolle $\mathrm{E}_{405 \mathrm{~nm}}=0,08$. D. h., durch die Inkubation mit 3\%igem Magermilchpulver wurde die Antigen-Antikörperreaktion so geblockt, dass Positiv- und Negativkontrolle gleiche Extintionswerte hatten. Um die Empfindlichkeit zu verbessern, wurden die Bakterien $(X c p)$ in unseren Versuchen auf drei unterschiedlichen Medien angezogen und in zwei verschiedenen Puffern (Konjugatpuffer, 3\%ige Magermilch) verdünnt. Dadurch konnte die Empfindlichkeit jedoch nicht verbessert werden. Daher können die hier geprüften monoklonalen Antikörper für diagnostische Zwecke nicht empfohlen werden. Warum die Nachweisempfindlichkeit der monoklonalen Antikörper so gering war, konnte hier nicht untersucht werden. Für die von BENEDICT et al. (1990) entwickelten hochspezifischen monoklonalen Antikörper gegen $X c p$ werden keine Angaben zur Nachweisempfindlichkeit gemacht.

Das polyklonale Antiserum aus Aschersleben sollte ebenso wie das Konjugat 1:1000 verdünnt werden. In dieser Verdünnung konnte $X c p$ überhaupt nicht nachgewiesen werden. Erst bei der schwächeren Serum- und Konjugatverdünnung von 1:600 konnten die Bakterien in einer Konzentration von $10^{6} \mathrm{cfu} / \mathrm{ml}$ sehr schwach nachgewiesen werden. Das Problem lag darin, dass die Extinktionwerte der Negativkontrolle z. T. höher als die der Positivkontrolle waren. Nach CASPER und MAYER (1981) sollten aber die Extinktionswerte bei der Negativkontrolle den Wert von $\mathrm{E}_{405 \mathrm{~nm}}=0,1$ nicht überschreiten. Dagegen wurden 
hier bei der Anwendung der polyklonalen Antikörper Extinktionswerte von $\mathrm{E}_{405 \mathrm{~nm}}=0,2$ 0,6 gemessen. Die Nachweisempfindlichkeit konnte auch durch eine Blockierung mit 3\%iger Magermilchlösung nicht verbessert werden. Die Extinktionswerte bei der Positiv- und Negativkontrolle waren gleich und lagen bei $\mathrm{E}_{405 \mathrm{~nm}}=0,252$.

Nach den vorliegenden Versuchergebnissen mit dem Bioreba-Antiserum ergab sich als sichere Nachweisgrenze für Xanthomonas campestris pv. pelargonii eine Keimdichte von $10^{4} \mathrm{cfu} / \mathrm{ml}$. Die gleiche Nachweisgrenze für das Bioreba-Antiserum wurde auch von BRIELMAIER-LIEBETANZ und SADOWSKA-RYBAK (1994) bestimmt; denn bei dem publizierten "Antiserum $A$ “ handelte es sich um das Bioreba-Antiserum. Nur ein XcpStamm (GSPB Nr. 2514) zeigte in unseren Untersuchungen bessere Extinktionswerte und konnte bei $10^{3} \mathrm{cfu} / \mathrm{ml}$ nachgewiesen werden. Im Gemisch mit Pflanzensaft erreichten diese Werte manchmal nur $10^{5} \mathrm{cfu} / \mathrm{ml}$. Durch Versuche zur Optimierung des Verfahrens konnte die Empfindlichkeit nicht verbessert werden. Ein weiterer Nachteil bestand darin, dass bei Wiederholungen oft Schwankungen auftraten. Außerdem zeigten die Xcp-Stämme unterschiedliche Empfindlichkeiten. Um die Nachweisempfindlichkeit zu verbessern, wurde die Platte zunächst mit der Probe in Nährlösung bei $4{ }^{\circ} \mathrm{C}$ beschichtet. Hier konkurrieren die Antigene oftmals mit anderen Substanzen aus der Probenlösung um die Adsorptionsplätze. Dies kann nach dem Waschvorgang zu einer geringeren Antigenkonzentration in den Vertiefungen und damit letztlich zu niedrigeren Extinktionswerten führen (SUNDERAM et al., 1991). Auch in unseren Versuchen waren die Ergebnisse erheblich schlechter, wenn die Platten zunächst mit dem Antigen inkubiert wurden.

Mit dem polyklonalen Antikörper von Bioreba wurden bessere Extinktionswerte erst bei der niedrigen Verdünnung von 1:250 erreicht. Wegen der Schwankungen von einem Versuch zum anderen und der hohen Kosten der schwach verdünnten Antiseren wurde das Bioreba-Antiserum für die weiteren Versuche nicht eingesetzt.

Die Empfindlichkeit des polyklonalen Antiserums der Fa. Loewe war unterschiedlich gegenüber verschiedenen Xcp-Stämmen. Die Stämme GSPB Nr. 1956, 1957, 2503 und 2636 konnten bei $10^{3} \mathrm{cfu} / \mathrm{ml}$ sicher nachgewiesen werden, während die Extinktionswerte mit den Stämmen GSPB Nr. 203 und 1955 recht schwach waren. Im allgemeinen konnten aber $10^{3} \mathrm{cfu} / \mathrm{ml}$ sowohl in Reinkulturen als auch im Gemisch mit Pflanzenextrakt nachgewiesen werden.

Auch von der Fa. Loewe wurde als Nachweisempfindlichkeit für dieses Antiserum $10^{3}$ cfu/ml angegeben. Das Antiserum der Firma Loewe wurde wegen der Stabilität bei ver- 
schiedenen Konzentrationen, einer recht guten Reproduzierbarkeit und auch auf Grund des Preises als alternatives Antiserum zum IPO-Antiserum empfohlen.

Mit dem polyklonalen Antiserum vom IPO (Niederlande) wurden alle geprüften $X c p$ Stämme noch bei einer Keimdichte von $10^{3} \mathrm{cfu} / \mathrm{ml}$ sicher nachgewiesen. Dies galt sowohl für den Nachweis im Puffer als auch in Pflanzensaft. Da das IPO-Antiserum 1:1000 verdünnt werden konnte und die Ergebnisse sich in Wiederholungen sehr gut reproduzieren ließen, wurde dieses Serum in allen weiteren Versuchen eingesetzt.

\subsection{Erhöhung der Nachweisempfindlichkeit}

Viele Versuche zur Verbesserung der Nachweisempfindlichkeit ergaben, dass eine Inkubation der Platten mit 3\% Magermilch (nach Zugabe der IgG) um die freien Bindungsstellen abzusättigen, keine Vorteile brachte. Wenn die Bakterien in einem Gemisch mit Pflanzenextrakt detektiert werden sollten, wurden bessere Extinktionswerte erreicht, wenn die Pflanzenproben in 1\% PVP Puffer zermörsert und 10 min auf $100{ }^{\circ} \mathrm{C}$ erhitzt wurden. Eine weitere Verbesserung ergab sich, wenn im dritten Schritt des ELISA (IgG-KonjugatZugabe) 30 min länger inkubiert wurde.

Für die Anwendung polyklonaler Antikörper (IPO) wurden in 1\% PVP-Puffer als Probenpuffer bessere Extinktionswerte erreicht als mit Nährlösung. Die positive Wirkung von PVP war höchstwahrscheinlich auf eine Hemmung der Phenole zurückzuführen (NAMEC, 1973). Pelargonienpflanzen enthalten sehr viele phenolische Verbindungen, die dazu führen, dass die Hintergrundreaktion stärker ist (KNAPOVA, 1995).

Ein Hauptproblem, das in der Arbeit bei fast allen verwendeten Antiseren auftrat, waren die unerwünscht hohen Hintergrundwerte der Negativkontrolle. Dies ist ein bekanntes Problem in manchen ELISA-Verfahren. Die Extinktionswerte waren z. B. bei $10^{3} \mathrm{cfu} / \mathrm{ml}$ $E_{405 \mathrm{~nm}}=0,12$ und in der Negativkontrolle $\mathrm{E}_{405 \mathrm{~nm}}=0,15$. Es wurde häufig berichtet, dass Pflanzeninhaltsstoffe die Bindung der Antigene an die Beschichtungsantikörper blockieren und die Höhe der positiven Reaktion beeinflussen können. Auch können störende Probenbestandteile, wie z. B. phenolische Verbindungen, einen Einfluss auf die positiven und Hintergrundreaktionen haben. Pelargonienpflanzen enthalten sehr viele phenolische Verbindungen. Deshalb wurden die Proben 10 min auf $100{ }^{\circ} \mathrm{C}$ erhitzt. In unseren Untersuchungen von nicht erhitztem Pflanzenmaterial traten oft falsch-positive Reaktionen bei gesunden Proben auf. Nach UNGER (1989) handelt es sich dabei um einen Effekt, der auf einer hohen Bindungsstärke des frischen Pflanzenmaterials mit Kaninchengammaglobulin 
beruht. Besonders hohe Phenolgehalte der Proben oder die Bildung von Protein-Aähnlichen Proteinen oder Lectinen (PRIESTLEY und DAWEY, 1993) spielen dabei eine Rolle. Dieses Problem tritt dann auf, wenn noch freie Bindungsstellen in den Vertiefungen vorhanden sind. Der Zusatz eines Proteins im Puffer, welches die freien Kapazitäten absättigt und so die Anlagerung weiterer Verbindungen blockiert, kann den Effekt reduzieren. Bei dem hier vorliegenden ELISA konnten 0,1\% BSA und 3\%iges Magermilchpulver die Hintergrundwerte allerdings nicht reduzieren. Die hier vorgeschlagene 10-minütige Erhitzung des Pflanzenhomogenates auf $100{ }^{\circ} \mathrm{C}$ sollte jedoch dann nicht erfolgen, wenn die Antikörper gegen die Lipopolysaccharide gerichtet sind (BENEDICT et al., 1990). HEPPNER (1995) stellte fest, dass sich die Hintergrundreaktion sehr gut durch phosphatasefreies BSA reduzieren ließ. Dies kann durch eine Bindung von Phosphatasen aus dem BSA an die Bindungsstellen der Mikrotiterplatten begründet sein.

Die Nachweisempfindlichkeit der Bakterien im Pflanzenextrakt wurde wesentlich verbessert, wenn die Proben bei $26^{\circ} \mathrm{C}$ für $24 \mathrm{~h}$ in TC-Lösung inkubiert wurden, wodurch eine Zwischenvermehrung der Bakterien stattfand. Ein latenter Befall liegt oft bei nur $10^{2}$ $10^{3} \mathrm{cfu} / \mathrm{ml}$ Pflanzenextrakt. Mit den Antiseren, die auf dem Markt käuflich sind, ist es ziemlich schwer, solch einen latenten Befall nachzuweisen. Deswegen wurde eine Verdünnungsreihe von $10^{6}-10^{2} \mathrm{cfu} / \mathrm{ml}$ in Tween-Cellobiose-Lösung hergestellt, und zu jeder Konzentration wurden 0,5 g gesunde Pelargonienstengel als Scheibchen hinzugefügt und auch bei $26{ }^{\circ} \mathrm{C} 110$ UPM 24 h inkubiert. Der Vorteil der Tween-Cellobiose-Lösung liegt darin, dass das Wachstum anderer an Pelargonien vorkommender Bakterien (Erwinia herbicola, Xanthomonas zinniae, Pseudomonas fluorescens, Pseudomonas syringae pv. syringae) unterdrückt wird (Kapitel I). Dadurch wurde eine hohe Nachweisempfindlichkeit erreicht, weil keine Kreuzreaktionen mit den sich nur schwach vermehrenden Begleitorganismen auftraten. Auf diese Weise konnten noch sehr geringe Konzentrationen, wie $10^{2}$ $\mathrm{cfu} / \mathrm{ml}$, im Pflanzenextrakt nachgewiesen werden. Mit ähnlichen Verfahren wurde der Nachweis von Ralstonia solanacearum in latent befallenen Kartoffelknollen durchgeführt (DENISEN, 1981; ELPHINSTONE et al. 1996). Untersuchungen von CERNUSKO (1995) und HEPPNER (1995) zeigten, dass eine Biotinylierung der Detektionsantikörper nochmals eine Erhöhung der Sensitivität mit sich brachte. Im Rahmen dieser Arbeit wurde diese Methode nicht überprüft. 


\subsection{Spezifität der Antiseren}

Eine Voraussetzung für eine erfolgreiche Anwendung des ELISA-Verfahrens zur Diagnose von $X c p$ ist die Spezifität der Antikörper, d. h. es sollte keine Kreuzreaktion mit anderen Organismen auftreten. Die immunologische Spezifität ist eine relative von der Struktur des Antigens abhängige Eigenschaft. Beim Einsatz des ELISA besteht häufig die Gefahr, dass die Antikörper nicht nur mit dem Zielpathogen sondern auch mit Antigendeterminanten anderer verwandter Bakterien reagieren und so einen spezifischen Nachweis erschweren. So zeigten Untersuchungen von DÜMMEN (1994), dass es endophytisch lebende Bakterien in Pelargonien gibt, die im ELISA positiv reagieren. Allerdings waren diese Gattungen nicht phytopathogen. Nach MÖLLER (1994) reagierten Bakterien der Gattung Staphylococcus im ELISA positiv, wurden aber bisher nicht im Zusammenhang mit Pflanzen gefunden worden. TUNIER und STEPHENS (1989) konnten keine Kreuzraktion mit Erwinia, Pseudomonas, Clavibacter und Agrobacterium feststellen, während gegenüber anderen Xanthomonas-Pathovarietäten noch ein Kreuzreaktion feststellbar war. Auch in dieser Arbeit wurden mit dem ELISA-Verfahren Versuche mit anderen Bakterien durchgeführt, die ebenfalls auf Pelargonien vorkommen können. Hierzu zählen Erwinia herbicola, Xanthomonas zinniae und Pseudomonas fluorescens. Bei einer Keimzahlkonzentration von $10^{7} \mathrm{cfu} / \mathrm{ml}$ wurde keine Kreuzreaktion mit den überprüften polyklonalen Antikörpern (IPO, BIOREBA und LOEWE) gegenüber anderen pflanzenpathogenen Bakterien festgestellt.

\subsection{Nachweis von $X c p$ in latent befallenen Pelargonienpflanzen durch das DAS- ELISA-Verfahren}

Nach der Optimierung des ELISA wurden latent infizierte Pflanzen untersucht. Noch 4 Jahre nach Infektion konnten in latent befallenen, symptomlosen Pflanzen durch das ELISA-Verfahren mit dem polyklonalen Antiserum vom IPO die Bakterien nachgewiesen werden. Einen noch empfindlicheren Nachweis in latent befallenen Pflanzen ergab die direkte mikrobiologische Ausplattierung. Einerseits war die Sensitivität des ELISAVerfahrens nicht so hoch wie der mikrobiologische Test, andererseits täuschten abgestorbene $X c p$-Bakterien in der Pflanze einen aktuellen Befall mit lebenden Bakterien vor. Nur nach einer Zwischenvermehrung der gesuchten Bakterien im Pflanzenextrakt bei Zugabe von Tween-Cellobiose-Lösung konnte mit dem ELISA eine gleich hohe Nachweisempfindlichkeit erreicht werden, wie durch die mikrobiologische Methode. 
Nach IDCZAK et al. (1996) reagierten hitzegetötete Xcp-Bakterien im ELISA genauso empfindlich wie nicht behandelte Bakterien. Dagegen berichtete WALDOW (1997), dass die Dauersporen von Plasmodiophora barassicae einer frisch hergestellten und einer für mehrere Stunden auf $100{ }^{\circ} \mathrm{C}$ erhitzten Sporensuspension unterschiedlich reagierten. Die Extinktionswerte lagen bei gleicher Konzentration bei den lebenden Sporen höher als bei den abgetöteten. Ähnliche Ergebnisse wurden bei unseren Versuchen beobachtet, in welchen die $X c p$-Suspension einmal für $10 \mathrm{~min}$ auf $100{ }^{\circ} \mathrm{C}$ erhitzt, die andere Suspension nicht erhitzt wurde. Die Extinktionswerte lagen bei den nicht abgetöteten höher als bei den hitzebehandelten Xcp-Zellen. Der ELISA reagierte auf abgetötete Bakterien weniger empfindlich. Trozdem wird diese Hitzebehandlung empfohlen, weil dadurch eine höhere Stabilität zwischen den Konzentrationen und eine gute Reproduzierbarkeit gewährleistet Inannseren Versuchen waren die Extinktionswerte der Positivkontrolle (gesunde junge Pelargonienstengelscheibchen oder -homogenate) höher als solche aus alten, verholzten Pelargonienstengeln, die latent infiziert waren. D. h., die Nachweisempfindlichkeit wurde durch Substanzen aus den alten Pelargonienstengeln sehr beeinträchtigt. Diese Schwankungen wurden auch in Kartoffelblättern für den ELISA-Nachweis von Phytophthora infestans festgestellt und mit der Reaktion der Pflanze in Abhängigkeit vom physiologischen Alter der Blätter, der Umwelt und von genetischen Faktoren erklärt (HARRISON et al., 1991; GOTTSCHALK, 1998).

\subsection{Nachweis von $X c p$ mit Hilfe der Immunfluoreszenz}

Neben dem quantitativen und spezifischen Nachweis des Erregers in der Testpflanze mit dem ELISA bieten immunologische Methoden auch die Möglichkeit, Xcp direkt in der Pflanze sichtbar zu machen.

In der Phytopathologie werden die direkte und indirekte Immunfluoreszenz (IF) angewendet. In dieser Arbeit wurde die indirekte IF angewendet. Bei der direkten IF werden bakterienspezifische IgG selbst mit einem Fluoreszenzfarbstoff gekoppelt, bei der indirekten IF werden Antispezies-Antikörper, die mit Fluoreszenzfarbstoff konjugiert sind, zum Nachweis eingesetzt. Nach Anregung mit UV-Licht (400 - $550 \mathrm{~nm}$ ) emittieren diese Farbstoffe Licht bestimmter längerer Wellenlängen, so dass angefärbte Zellen charakteristisch leuchten.

Der IF-Test gehört in der Literatur zu den empfindlichsten Nachweisverfahren. Die Nachweisgrenze lag für Erwinia amylovora (Feuerbrand) bei $10^{2}-10^{3}$ Zellen/ml im Pflanzen- 
saft (SADOWSKA-RYBAK, 1992). BRIELMAIER-LIBETANZ et al. (1994) stellten zum Nachweis von Xcp fest, dass bei Verwendung des gleichen Antiserums der IF-Test eine Zehnerpotenz empfindlicher war als der ELISA-Test. Allerdings gab es noch einige Unsicherheiten, vor allem hinsichtlich der sogenannten falsch-positiven Ergebnisse, das heißt, dass die Autofluoreszenz pflanzlicher Gewebe die Interpretation der FITC-Fluoreszenz erschwerte.

Die in dieser Arbeit im IF-Test verwendeten polyklonalen Antikörper der Firmen BIOREBA und IPO zeigten, dass $X c p$ sowohl mit Reinkulturen als auch im Pflanzensaft mit einem Antikörper und Konjugat bei 1:100 Verdünnung $10^{2}$ Zellen/ml nachgewiesen wurden. Allerdings konnte bei latent befallenen Pflanzen nach Homogenisierung der Proben der gleiche Erfolg nicht erreicht werden, weil das Pflanzengewebe die Erkennung der echten Fluoreszenz erschwerte. Es war schwierig, $10^{3} \mathrm{cfu} / \mathrm{ml}$ Bakterien in der Pflanze nachzuweisen.

Beim Einsatz von Immunfluoreszenzmethoden können sich wie im ELISA Kreuzreaktionen mit anderen Organismen oder die Autofluoreszenz pflanzlicher Gewebe störend auswirken. Die Autofluoreszenz kann somit die echte Fluoreszenz maskieren oder Schwierigkeiten bei der Interpretation der echten Fluoreszenz bereiten. Bei der Mikroskopie unter UV-Licht lässt sich die Autofluoreszenz nicht völlig vermeiden. Auslösend sind vor allem Proteine, Carotinoide, Chlorophyll und bestimmte Alkaloide (KASTEN, 1981). Bei unseren Untersuchungen wurde die Autofluoreszenz des pflanzlichen Gewebes als recht störend eingeschätzt. Dieser Nachteil könnte vielleicht durch die Verwendung eines anderen Farbstoffs, wie Cy3 (Indocarbocyanin) mit einem anderen Anregungs- und Emissionsspektrum, vermindert werden. Eine andere Möglichkeit wäre, die Proben für 10 min auf $100{ }^{\circ} \mathrm{C} \mathrm{zu}$ erhitzen. Der ELISA reagierte auf abgetötete Zellen zwar wenig empfindlich aber gut reproduzierbar. Da bei der Immunfluoreszenz mit denselben Antikörpern gearbeitet wird, die für den ELISA eingesetzt werden, ist Gleiches für diese Methode anzunehmen. 


\section{ZUSAMMENFASSUNG}

1 In dieser Arbeit wurden 4 polyklonale Antiseren (BAZ, Aschersleben; BIOREBA; LOEWE; IPO, Wageningen) und 1 monoklonales Antiserum (BAZ, Aschersleben) zum Nachweis von Xanthomonas campestris pv. pelargonii im ELISA verglichen.

2. Das monoklonale Antiserum (BAZ, Aschersleben) erlaubte bei einer Verdünnung von 1:200 noch einen Bakteriennachweis von $\mathbf{1 0}^{6} \mathbf{c f u} / \mathbf{m l}$, niedrigere Konzentrationen konnten nicht mehr sicher nachgewiesen werden.

3. Mit dem polyklonalen Antiserum (BAZ, Aschersleben), geprüft unter verschiedenen Serum- und Konjugatverdünnungen, konnten die Bakterien auch in einer Konzentration von $10^{6} \mathbf{c f u} / \mathbf{m l}$ nicht sicher nachgewiesen werden.

4. Mit dem polyklonalen Antiserum der Fa. Bioreba konnten 5 getestete Xcp-Stämme (GSPB Nr.1955, 1956, 1957, 2503 und 2636) noch bei einer Bakterienkonzentration von $\mathbf{1 0}^{\mathbf{4}} \mathbf{~ c f u / m l}$ nachgewiesen werden. Nur ein Xcp-Stamm (GSPB Nr. 2514) wurde recht schwach bei $10^{3} \mathrm{cfu} / \mathrm{ml}$ nachgewiesen. Die optimale Verdünnung des Antiserums betrug $1: 250$.

5. Mit dem polyklonalen Antiserum der Fa. Loewe, 1:200 verdünnt, konnten alle 5 getesteten $X c p$-Stämme bei $\mathbf{1 0}^{3} \mathbf{c f u} / \mathbf{m l}$ nachgewiesen werden, davon 3 Stämme sicher (GSPB Nr. 2503, 2514 und 2632) und 2 Stämme schwach (GSPB Nr. 203 und 1955).

6. Das polyklonale Antiserum vom IPO (Niederlande) zeigte die höchste Empfindlichkeit. Noch bei einer Verdünnung von 1:1000 wurden alle getesteten $X c p$-Stämme (GSPB Nr. 203, 1955, 2503, 2514 und 2632) herunter bis $\mathbf{1 0}^{3} \mathbf{~ c f u / m l ~ s i c h e r ~ n a c h g e w i e s e n . ~ A u f ~}$ Grund der guten Reproduzierbarkeit von Wiederholungen wurde das IPO-Antiserum für alle weiteren Versuche verwendet.

7. Die Antiseren von BIOREBA, LOEWE und IPO zeigten keine Kreuzreaktionen mit anderen phytopathogenen und saprophytischen Bakterien, wie Xanthomonas campestris pv. zinniae, Erwinia herbicola und Pseudomonas fluorescens. 
8. Bei Mischung von Pflanzenextrakt im Extraktionspuffer (PBS + 0,05\% Tween $20+$ 1\% PVP) mit Bakteriensuspensionen konnten mit dem Antiserum vom IPO ebenfalls $\mathbf{1 0}^{3}$ $\mathbf{c f u} / \mathbf{m l}$ nachgewiesen werden. In ähnlichen Versuchen wurden mit dem Antiserum der Fa. Loewe $10^{3} \mathbf{~ c f u} / \mathbf{m l}$ nachgewiesen, wenn die Bakterien mit Pflanzenextrakt im PelargoniumPuffer gemischt wurden. Der Nachweis der Bakterien im Pflanzenextrakt war besser, wenn der Pflanzenextrakt 10 min auf $100{ }^{\circ} \mathrm{C}$ erhitzt wurde.

9. Auch in Homogenaten alter, teilweise verholzter Pelargonienstengel, die seit 4 Jahren latent mit $X_{c p}$ infiziert waren, konnten mit dem IPO-Antiserum die Bakterien bei einer Konzentration von $10^{3} \mathrm{cfu} / \mathrm{ml}$ noch nachgewiesen werden. Dabei zeigte sich, dass Substanzen aus den alten Pelargonienstengeln die Nachweisempfindlichkeit durch den ELISA beeinträchtigten.

10. Noch empfindlicher war allerdings der mikrobiologische Test, durch den in den Homogenaten noch 2 x $\mathbf{1 0}^{2}$ cfu/g Stengel detektiert wurden.

11. Einige Pflanzenproben wurden durch den ELISA positiv bewertet, obwohl im mikrobiologischen Test keine Bakterien gefunden wurden, wahrscheinlich weil durch den ELISA nur noch tote Bakterien erfasst wurden.

12. Die Nachweisempfindlichkeit der Bakterien im Pflanzenextrakt wurde wesentlich verbessert, wenn die Proben bei $26^{\circ} \mathrm{C}$ für $24 \mathrm{~h}$ in TC-Lösung inkubiert wurden, wodurch eine Zwischenvermehrung der Bakterien stattfand. Dann konnte mit dem IPO-Antiserum noch eine ursprüngliche Konzentration von $\mathbf{1 0}^{\mathbf{2}} \mathbf{c f u} / \mathbf{m l}$ in der Pflanze nachgewiesen werden.

13. Es wurde ein Protokoll für den ELISA mit 2 Veränderungen gegenüber publizierten Protokollen erarbeitet: Die Inkubationszeit der Mischung von Bakterien mit Antiserum wurde auf 19 - 20 h über Nacht bei $4{ }^{\circ} \mathrm{C}$ verlängert, nach Zugabe des Konjugates wurde für $4,5 \mathrm{~h}$ bei

$37^{\circ} \mathrm{C}$ inkubiert.

14. Durch den Immunfluoreszenz-Test konnten $10^{2}-\mathbf{1 0}^{3} \mathbf{c f u} / \mathbf{m l}$ in Reinkulturen mit den Antiseren von IPO, LOEWE, und BIOREBA nachgewiesen werden. Allerdings wurde bei latent befallenen Pflanzen nach Homogenisierung der Proben der gleiche Erfolg nicht erreicht, weil Substanzen aus dem Pflanzengewebe die Erkennung der echten Fluoreszenz erschwerten. Es war schwierig, $10^{3} \mathrm{cfu} / \mathrm{ml}$ Pflanzenextrakt nachzuweisen. 
KAPITEL IV

\section{NACHWEIS VON XANTHOMONAS CAMPESTRIS PV. PELARGONII MIT DER POLYMERASE-KETTENREAKTION (PCR)}

\section{EINLEITUNG}

Xanthomonas campestris pv. pelargonii $(X c p)$ verursacht an Pelargonien eine Stengelfäule und Blattfleckenkrankheit, die durch chemische Pflanzenschutzmittel nicht bekämpft werden kann. Zur Zeit besteht der einzige Weg einer praktischen Bekämpfung darin, die Einführung von kontaminiertem Pflanzenmaterial in Vermehrungsbeständen zu verhindern. Dies ist schwierig, weil die Bakterien für längere Zeit unerkannt in gesund erscheinenden Pflanzen überdauern können (Kaptel II). Um eine latente Infektion bei einer großen Probenanzahl feststellen zu können, ist daher eine empfindliche, praktikable und schnelle Diagnosemethode erforderlich. Nach KLOPMEYER (1992) sollte für das Vermehrungsmaterial von Pelargonien eine "Null-Toleranz“ für Xcp gefordert werden, da nur auf diese Weise die Krankheit eliminiert werden kann, und weil mit den zur Verfügung stehenden Methoden dieses Ziel realisiert werden kann.

Zum Nachweis des Krankheitserregers kamen bisher serologische Nachweisverfahren wie der ELISA und der Immunofluoreszenz-Test (IF-Test) (Kapitel III) sowie die Isolierung durch Plattierung auf einem semiselektiven Nähragar (Kapitel I) zur Anwendung. Allerdings sind serologische Nachweismethoden noch mit Unsicherheiten behaftet, die zu falschen Ergebnissen oder zumindest Fehlerinterpretationen führen können (BERKELMANN et al., 1993; MANULIS et al., 1994) (Kapitel III).

Seit Einführung gentechnischer Methoden wurde Xcp bisher noch wenig molekularbiologisch untersucht. Nach MANULIS et al. (1994) setzten SULZINSKI et al. (1995) die PCR-Technik zur Charakterisierung von Xcp ein. Mit einem ERIC-Primerpaar stellten die Autoren fest, dass sämtliche von ihnen getesteten 19 Xcp-Stämme zwei Haupt-DNAProdukte von schätzungsweise $500+740$ bp besaßen. Die Verwendung eines REPPrimerpaares ergab komplexere Fingerabdrücke mit Haupt-DNA-Produkten von etwa 690 bis 1650 bp. Die mit ERIC- und REP-Primern erhaltenen Fingerabdrücke erlaubten eine 
Unterscheidung der Xanthomonas campestris pv. pelargonii-Stämme von den anderen untersuchten Pathovarietäten citrumelo, citri, begoniae, vitians $B$ und $C$, phaseoli, campestris, manihotis, juglandis, carotae und pruni. Daraufhin entwickelte diese Arbeitsgruppe (SULZINSKI et al,. 1996) das Primer-Paar XcpM1/XcpM2, mit dem zum ersten Mal durch die PCR Xcp in planta nachgewiesen werden konnte. Später wurde ein weiteres Primer-Paar von KRÄMER et al. (1998) entwickelt.

Deswegen wurde in dieser Arbeit untersucht, ob ein empfindlicher Nachweis von Xcp neben serologischen Methoden auch durch den Einsatz der PCR-Technik möglich ist. Dabei sollte neben der Überprüfung der diagnostischen Primer von KRÄMER et al. (1998) unter praxisnahen Bedingungen überprüft werden, ob die PCR-Technik ohne eine komplizierte DNA-Extraktionsmethode einfach mit den Homogenaten der Proben durchgeführt werden kann, um einen hoch sensitiven $X c p$-Nachweis in latent befallenen Pelargonienpflanzen zu gewährleisten. 


\section{MATERIAL UND METHODEN}

\subsection{Bakterienstämme}

Die in die vorliegenden Arbeit verwendeten Bakterienstämme aus der „Göttinger Sammlung Phytopathogener Bakterien“ (GSPB) sind in der Tab. 1 zusammengestellt.

Tab. 1: Verwendete Bakterienstämme (siehe auch Tab. 1 in Kapitel I)

\begin{tabular}{lr}
\hline Bakterienart & GSPB-Nr.: \\
\hline \hline Xanthomonas campestris pv. pelargonii & 191 \\
Xanthomonas campestris pv. pelargonii & 192 \\
Xanthomonas campestris pv. pelargonii & 203 \\
Xanthomonas campestris pv. pelargonii & 1934 \\
Xanthomonas campestris pv. pelargonii & 1955 \\
Xanthomonas campestris pv. pelargonii & 1957 \\
Xanthomonas campestris pv. pelargonii & 2104 \\
Xanthomonas campestris pv. pelargonii & 2105 \\
Xanthomonas campestris pv. pelargonii & 2503 \\
Xanthomonas campestris pv. pelargonii & 2513 \\
Xanthomonas campestris pv. pelargonii & 2514 \\
Xanthomonas campestris pv. pelargonii & 2630 \\
Xanthomonas campestris pv. pelargonii & 2632 \\
Xanthomonas campestris pv. pelargonii & 2638 \\
Xanthomonas campestris pv. pelargonii & 2640 \\
Xanthomonas campestris pv. pelargonii & 2642 \\
Xanthomonas campestris pv. malvacearum & 1430 \\
Xanthomonas campestris pv. viginicola & 2509 \\
Xanthomonas campestris pv. zinniae & 5762 \\
Erwinia herbicola & 450 \\
Pseudomonas syringae pv. syringae & 1714 \\
Pseudomonas fluorescens & \\
\hline & \\
&
\end{tabular}




\section{$2.2 \quad$ Nährmedien}

Die hier verwendeten Nährmedien wurden im Kapitel I und die Puffer im Kapitel III unter 2.2.1.4 beschrieben.

\subsection{Kultivierung der Bakterien}

Xanthomonaden wurden auf dem NGA- oder NGAR-Medium und Pseudomonaden sowie Erwinia auf dem KB-Medium angezogen. Die Bebrütung erfolgte $48 \mathrm{~h}$ bei $25{ }^{\circ} \mathrm{C}$. Aus einer typischen Kolonie wurde noch einmal auf das jeweilige Medium überimpft und $24 \mathrm{~h}$ bei $25{ }^{\circ} \mathrm{C}$ kultiviert. Die frischen Kulturen wurden in sterilem bidest. Wasser suspendiert und photometrisch bei $660 \mathrm{~nm}$ auf eine optische Dichte von 0,06 eingestellt. Von dieser Ausgangskonzentration (ca. $10^{8} \mathrm{cfu} / \mathrm{ml}$ ) wurden Verdünnungsreihen von $10^{7}$ bis $10^{2} \mathrm{cfu} / \mathrm{ml}$ für die Versuche hergestellt.

\subsection{Vorbereitung des Pflanzenmaterials für die PCR}

\subsubsection{Für die normale PCR}

Jeweils 0,5 g Frischstengelgewebe wurden unter Zugabe von $1 \mathrm{ml}$ TE-Puffer (10 mM Tris -HCI, pH 8.0, 1 mM EDTA) in einem sterilen Mörser homogenisiert. Die Proben wurden aus kranken oder gesunden Pelargonienstengeln gewonnen. Im zweiten Fall wurde dem Pflanzenhomogenat eine bestimmte Menge Bakteriensuspension hinzugegeben, deren Bakterienkonzentration photometrisch bei $660 \mathrm{~nm}$ eingestellt wurde.

\subsubsection{Für die BIO-PCR}

"BIO-PCR" wurde ähnlich wie bei SCHAAD et al. (1995) durchgeführt, um die Sensitivität der Methode zu erhöhen. Die Proben wurden in einer TC-Lösung (semiselektives flüssiges Medium) (siehe Kapitel I) zwischenvermehrt.

Kranke Pelargonienpflanzen mit gut ausgeprägten Symptomen an den Stengeln stammten aus den Versuchen, die im Kapitel II (inokulierte Pflanzen) beschrieben werden. Zur Kontrolle dienten gesunde Pelargonienpflanzen. Stengelstücke von 0,5 g Frischgewebe wurden 
in $70 \%$ Et-OH sterilisiert, kurz abgeflammt und mit $1 \mathrm{ml}$ sterilem bidest. Wasser in einem Mörser homogenisiert oder in ganz dünne Scheibchen zerschnitten.

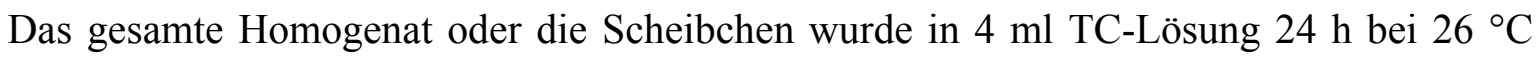
kultiviert (Zwischenvermehrung der gesuchten Bakterien). Von der Suspension wurden 2 ml entnommen und bei 12.000 RPM 20 min zentrifugiert. Das Pellet wurde in $500 \mu 1$ sterilem bidest. $\mathrm{H}_{2} \mathrm{O}$ aufgenommen. Diese Suspension wurde in bidestilliertem Wasser in 1:10er Schritten bis $10^{7}$ verdünnt und für die PCR verwendet.

\subsection{Molekulargenetische Methoden}

\subsubsection{Sterilisation von Geräten und Lösungen}

Alle hitzestabilen Lösungen und Geräte wurden für 15 min bei $120^{\circ} \mathrm{C}$ autoklaviert. Nicht autoklavierbare Materialien und Geräte wurde mit 70\%igem Ethanol abgespült.

\subsubsection{Stammlösungen und Puffer}

TC-Lösung (Kapitel I) und NB-Lösung (Kapitel III) wurden wie dort beschrieben hergestellt.

TE-Puffer

$\begin{array}{lll}\text { Tris } & 10 & \mathrm{mM} \\ \text { EDTA } & 1 & \mathrm{mM} \\ \mathrm{pH} & 8.0 & \end{array}$

Der TE-Puffer wurde autoklaviert.

$10 \times$ TBE-Puffer

$\begin{array}{lll}\text { Tris } & 0,9 & \mathrm{M} \\ \mathrm{H}_{3} \mathrm{BO}_{3} & 0,9 & \mathrm{M} \\ \text { EDTA } & 20 & \mathrm{mM}(40 \mathrm{ml})\end{array}$


2.5.3 DNA-Extraktion (nach KRÄMER et al., 1998)

- Stengeloberfläche mit 70\%igem Alkohol abspülen und mit Papiertüchern abtrocknen

- $50 \mathrm{ml}$ Erlenmeyer-Kolben mit 5 oder $10 \mathrm{ml} \mathrm{NB}$ befüllen (je nach Menge des Pflanzenmaterials)

- Stengel in $2 \mathrm{~mm}$ große Scheibchen schneiden und in die NB-Lösung geben

- über Nacht bei $25^{\circ} \mathrm{C}$ schütteln

- Schüttelsuspension ohne Stengelstücke in Zentrifugenröhrchen umfüllen

- 20 min bei $1500 \mathrm{rpm}$ zentrifugieren

- Überstand verwerfen, Vorsicht!! -Sediment ist nicht sehr fest, Sediment in $200 \mu 1 \mathrm{TE}-$

Puffer aufnehmen und in Eppendorf-Röhrchen umfüllen

- 10 min im Wasserbad bei $100{ }^{\circ} \mathrm{C}$ kochen

- $50 \mu \mathrm{l}$ M NaOH und $125 \mu 11 \mathrm{M}$ TRIS-HCI, pH 8.0 zugeben

- 3 min bei $12.000 \mathrm{rpm}$ zentrifugieren

- Überstand absaugen und in neue Röhrchen überführen

- Folgende Verdünnungen in tridest. $\mathrm{H}_{2} \mathrm{O}$ für PCR herstellen: 1:10, 1:100, 1:1000

- $1 \mu 1$ der Verdünnungen in der PCR einsetzen

\subsubsection{Agarose-Gelelektrophorese}

Zur analytischen oder präparativen Auftrennung der Nukleinsäuren wurde eine horizontale Agarose-Gelelektrophorese in im Eigenbau gefertigten Kammern durchgeführt. Die eingesetzte Agarosekonzentration betrug 1,7\%. Zur Herstellung des Agarose-Gels wurde 1,7 g Agarose in $100 \mathrm{ml}$ TBE-Puffer (0,5 x TBE, pH: 8.0) aufgenommen und die Lösung in einer Mikrowelle erhitzt, bis keine Trübung mehr sichtbar war. Nach Abkühlen auf $50{ }^{\circ} \mathrm{C}$ wurde sie in die Gelkammer gegossen. Die Trennung erfolgte bei einem Elektrodenstand von $30 \mathrm{~cm}$ und einer Spannung von $80-100 \mathrm{~V}$ in TBE-Laufpuffer.

Als Größenstandards für Nukleinsäuren diente pBR322/AluI (Fermentas, St. Leon-Rot) mit folgenden Fragmentgrößen:

$908 ; 659 ; 656 ; 521 ; 403 ; 281 ; 257 ; 226 ; 100 ; 90 ; 63 ; 57 ; 49 ; 46 ; 19 ; 15 ; 11$ bp. 


\subsubsection{Ethidiumbromid-Färbung und Fotografie der Gele}

Nach der Elektrophorese wurden die Gele 10 - 15 min in ein Ethidiumbromidwasserbad (0,5 $\mu \mathrm{g} / \mathrm{ml}$, Fluka, Neu-Ulm) gelegt, um die Nukleinsäuren nachweisen zu können. Zur Verbesserung der Kontrastierung wurde das Gel 5 - 10 min in einem Wasserbad entfärbt. Der Nukleinsäure-Ethidiumbromid-Komplex kann durch kurzwelliges UV-Licht (254 $360 \mathrm{~nm}$ ) angeregt werden und emittiert Licht im Bereich von $590 \mathrm{~nm}$.

Zur Dokumentation der Gele wurde eine an einen Computer angeschlossene Videokamera verwendet. Diese erfasst das durch den Nukleinsäure-Ethidiumbromid-Komplex emittierte Licht, so dass sowohl die Dokumentation als auch die Auswertung über eine spezielle Software (Molecular Analysist, Biorad, Hagen) möglich war. Es wurde eine Polaroidkamera (MP4, Cambridige, MA, USA) mit Rotfilter verwendet, wenn ein besserer Kontrast nötig war.

\subsubsection{Polymerase-Kettenreaktion (PCR)}

Alle Amplifikationsansätze wurden im Thermocycler OmniGene der Firma Hybaid durchgeführt. Nukleotide, die Polymerase (DyNAzyme) und Enzympuffer wurden von den Firmen BIOMETRA und QIAGEN bezogen. Als Amplifikationsproben wurden Pflanzenund Gesamt-DNA-Extrakte sowie Bakteriensuspensionen verwendet. Die eingesetzten Primer (KRÄMER et al., 1998) mit den Sequenzen Forward Primer GAGTGTCCAGTGGCAAGC (Primer XCP1) und Reverse Primer GTTGCTGCCTCTTCCTGC (Primer XCP2) wurden von der Firma ROTH synthetisiert. 
Das PCR-Reaktionsgemisch mit einem Gesamtvolumen von $50 \mu 1$ setzte sich nach der Optimierung der wichtigsten Reaktionsparameter Annealing-Temperatur, Primer und Polymerase (DyNAzyme) wie folgt zusammen (Tab. 2):

Tab. 2: PCR-Ansatz für $50 \mu 1$ Endvolumen

\begin{tabular}{l|l|l}
\hline Komponenten & Volumen & Konzentration \\
\hline \hline Polymerasepuffer & $5,0 \mu 1$ & $10 \mathrm{x}$ \\
dNTP-Mix & $0,5 \mu 1$ & $20 \mathrm{mM}$ \\
Primer XCP1 & $2,0 \mu 1$ & $10 \mathrm{pmol} / \mu 1$ \\
Primer XCP2 & $2,0 \mu \mathrm{l}$ & $10 \mathrm{pmol} / \mu 1$ \\
Polymerase & $0,5 \mu 1$ & $2 \mathrm{U} / \mu \mathrm{l}$ \\
Probe Bakteriensuspension & $40 \mu 1$ & \\
oder DNA $+\mathrm{H}_{2} \mathrm{O}$ bidest. & $40 \mu \mathrm{l}$ & \\
\hline
\end{tabular}

Die Ansätze wurden gemischt, mit $50 \mu 1$ Mineralöl überschichtet und im PCR-Block 4 min bei $94{ }^{\circ} \mathrm{C}$ denaturiert. Es schlossen sich 40 der folgenden Temperaturzyklen an:

$\rightarrow 1$ min bei $94{ }^{\circ} \mathrm{C}$ (Denaturierung der DNA)

$\rightarrow 1$ min bei $63{ }^{\circ} \mathrm{C}$ (Annealingtemperatur)

$\rightarrow 2$ min bei $72{ }^{\circ} \mathrm{C}$ (Amplifikation der DNA)

Zum Schluss wurde 10 min auf $72{ }^{\circ} \mathrm{C}$ erhitzt.

Um die Kontaminationsgefahr zu verringern, wurden sämtliche Arbeitsschritte zur DNAReinigung und Durchführung der PCR in getrennten Räumen durchgeführt. Als weitere vorbeugende Maßnahmen wurden separate Sätze von Mikroliterpipetten und autoklavierte Reaktionsgefäße verwendet, die nur für PCR vorgesehen waren (KOOPMANN, 1999).

\section{Elektrophorese:}

Nach 40 PCR-Reaktionszyklen wurden $10 \mu$ PCR-Produkte mit 1,5 $\mu 1$ 6x Loading Dye Lösung (Fa. Fermentas) gemischt und in die Geltasche pipettiert. Zur Bestimmung des Molekulargewichtes kam der Marker pBR322 /AluI (1,5 $\mu 1$ 6x Loading Dye Lösung $+7 \mu 1$ $\mathrm{H}_{2} \mathrm{O}+1,3$ pBR322 /AluI gut mischen) zum Einsatz. 


\section{ERGEBNISSE}

3.1 DNA-Extraktion (wie in 2.5 .3 beschrieben)

\subsubsection{Aus Bakterienreinkulturen}

Der direkte Bakteriennachweis aus Pflanzenextrakten wird häufig durch phenolische Verbindungen gestört, welche die Taq-Polymerase hemmen. Deswegen wurde zunächst geprüft, ob die DNA-Extraktion nach einem Protokoll von KRÄMER et al. (1998) (siehe 2.5.3) mit Bakterienreinkulturen möglich ist. Wenn $10 \mu 1$ extrahierte DNA auf 0,8\% Agarose Gel aufgetragen wurden, zeigte sich nur bei hohen Konzentrationen $\left(10^{8}\right.$ und $10^{7}$ $\mathrm{cfu} / \mathrm{ml}$ ) auf dem Gel ein positives Signal, dagegen nicht bei $10^{2}$ bis $10^{6} \mathrm{cfu} / \mathrm{ml}$.

Das Pellet der Bakterien war nach dem Abzentrifugieren sehr weich und oft schwer zu erkennen. Vielleicht beruhte darauf die Unempfindlichkeit dieser Methode.

\subsubsection{PCR-Nachweis der Bakterien in planta}

Bei DNA-Extraktion aus infizierten Pflanzen und folgender PCR wurde überhaupt kein positives Signal beobachtet. Diese Methode erwies sich damit auch zum Bakteriennachweis aus infizierten Pelargonien als ungeeignet.

\subsection{Nachweisgrenze von Xcp-Reinkulturen durch die PCR}

Von einer Xcp-Reinkultur (GSPB 2503) wurde eine Suspension mit einer OD von 0,06 bei $660 \mathrm{~nm}$ hergestellt und in 1:10er-Schritten verdünnt. Ein $40 \mu$ l Aliquot der Verdünnungsstufen wurde für den PCR-Nachweis verwendet. In Abb. 1 sind die Amplifikationsprodukte dargestellt. Mit abnehmender Bakterienkonzentration nahm die Intensität der diagnostischen Bande ab. Während bei $10^{3} \mathrm{cfu} / \mathrm{ml}$ bereits ein schwaches Signal zu erkennen war, trat bei $10^{4} \mathrm{cfu} / \mathrm{ml}$ ein deutliches Signal auf. 


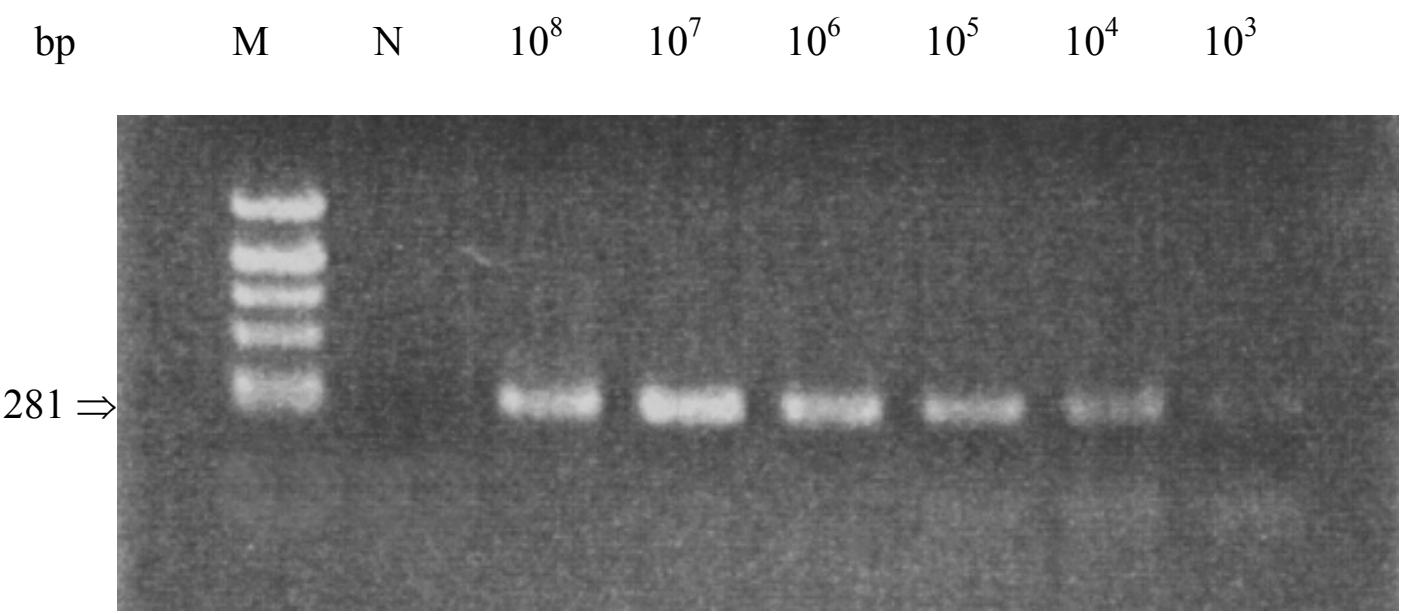

Abb. 1: Nachweisbare Bakterienzellen in einer Xcp-Reinkultur (GSPB 2503), M: Größenstandard pBR322/AluI, N: Negativkontrolle.

\subsection{In planta-Nachweis von Xcp durch die PCR}

Wie unter 2.4 beschrieben, wurde aus gesunden Pelargonienstengeln ein Homogenat hergestellt und mit $X c p$-Suspensionen definierter Konzentrationen vermischt. Das Gemisch wurde in 1:10er Schritten mit bidest. $\mathrm{H}_{2} \mathrm{O}$ verdünnt und direkt für die PCR verwendet. Aus dem unverdünnten Homogenat konnte kein positives Signal erzeugt werden. Hier wurde offensichtlich die Aktivität der Taq-Polymerase (BIOMETRA) durch Pflanzeninhaltstoffe inhibiert. Erst nachdem das Homogenat 1:10 verdünnt wurde, erschien die diagnostische Bande (Abb. 2). Auch bei $10^{4} \mathrm{cfu} / \mathrm{g}$ Stengelfrischgewicht war noch ein starkes Signal vorhanden. Wenn der gleiche Versuch mit einer anderen Taq-DNA-Polymerase (Fa. QIAGEN) durchgeführt wurde, erschien die diagnostische Bande erst, wenn das Homogenat 1:100 verdünnt wurde, und die Nachweisgrenze betrug $10^{3} \mathrm{cfu} / \mathrm{g}$. 


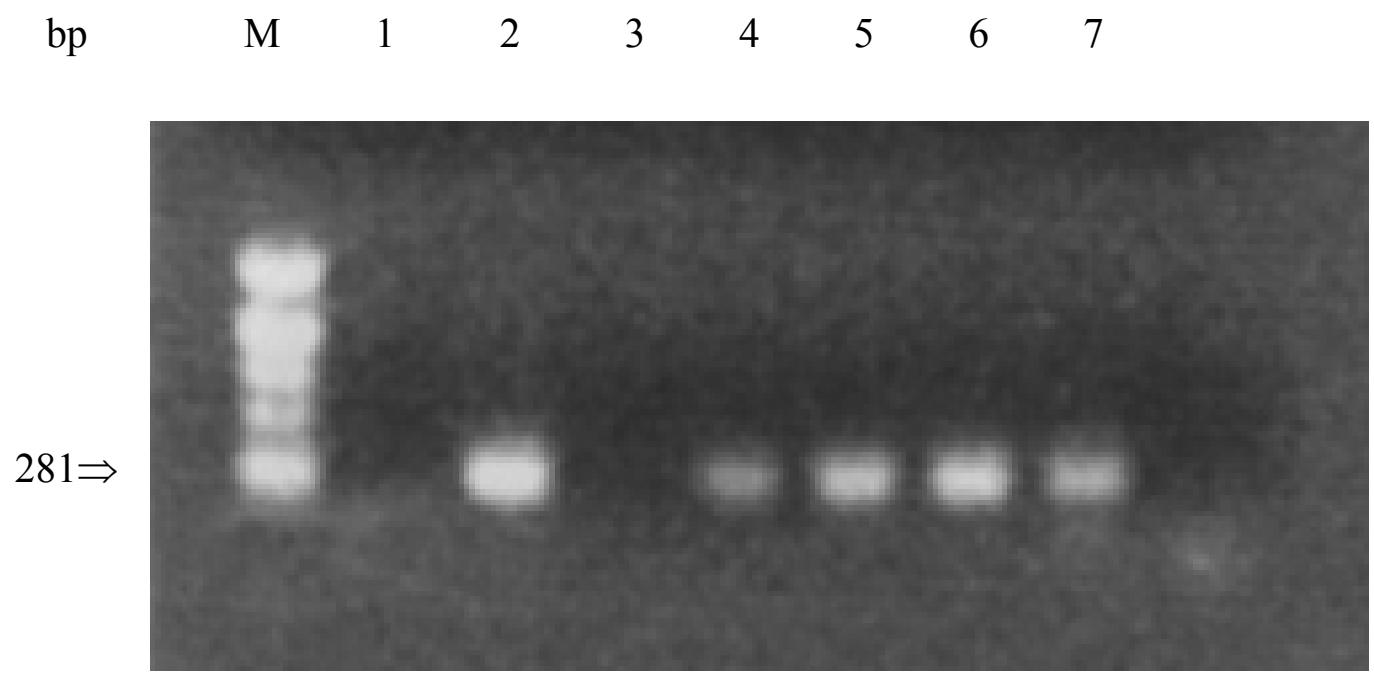

Abb. 2: Einfluss der Pflanzeninhaltstoffe auf die Amplifikation der spezifischen Bande bei der PCR, M: Größenstandard pBR 322/AluI, 1: Negativkontrolle, 2: Positivkontrolle mit $10^{8} \mathrm{cfu} / \mathrm{ml}$ Xcp-Zellen ohne Pflanzenhomogenat, 3 - 7 (Bakteriensupension mit Pflanzenhomogenat)

\subsection{BIO-PCR}

Bei der BIO-PCR, einer Kombination biologischer und enzymatischer Amplifikationstechniken, wird die Sensitivität des Nachweises dadurch erhöht, dass eine Zwischenvermehrung des Pathogens eingeschaltet wird (SCHAAD et al., 1995).

\subsubsection{BIO-PCR von $X c p$ nach Vorkultur von Pelargonienstengel-Scheibchen zu- sammen mit Bakteriensuspension in TC-Lösung}

In Vorversuchen wurden gesunde Pelargonienstengel-Scheibchen mit einer Bakteriensuspension von $10^{8} \mathrm{cfu} / \mathrm{ml}$ mit TC-Lösung gemischt und $24 \mathrm{~h}$ inkubiert. Zur Ermittlung der Nachweisgrenze wurden $100 \mu \mathrm{l}$ der jeweiligen Verdünnungsstufe auf NGAR-Medium gleich nach dem Ansetzen (0 h) und nach 24 h ausplattiert. Die Kolonien wurden nach 2 3 Tagen bei $28{ }^{\circ} \mathrm{C}$ gezählt (Tab. 3). In Tab. 3 ist die Vermehrung von Xcp in der TCLösung nach 24 h Inkubation in Reagenzgläsern wiedergegeben. Unter diesen Wachstumsbedingungen erhöhte sich die Bakterienpopulation etwa um das 20-fache, wodurch auch die PCR-Nachweisempfindlichkeit entsprechend verbessert wurde. 
Tab. 3: Konzentration von $X c p$ in der Mischung von Pelargonienscheibchen mit Bakteriensuspension und TC-Lösung (Bestimmung durch Ausplattierung der Verdünnungsstufen auf dem Standardmedium).

\begin{tabular}{c|c|c}
\cline { 2 - 3 } & \multicolumn{2}{c}{ Inkubationszeit } \\
\hline Verdünnungsstufe & $0 \mathrm{~h}$ & $24 \mathrm{~h}$ \\
\hline \hline VS6 & 119 & zusammengewachsen \\
\hline VS7 & 30 & 330 \\
\hline VS8 & 2 & 60 \\
\hline
\end{tabular}

Danach wurden $2 \mathrm{ml}$ Suspension bei 12.000 RPM für 20 min zentrifugiert, das Pellet in $500 \mu$ bidest. $\mathrm{H}_{2} \mathrm{O}$ aufgenommen, in 10er Schritten mit bidest. $\mathrm{H}_{2} \mathrm{O}$ verdünnt und für den PCR-Test verwendet. Das Abzentrifugieren der Bakterien war notwendig, um sie von anderen Substanzen der TC-Lösung (Antibiotikum, Zucker und Salze) zu trennen, welche die Aktivität der Taq-Polymerase unterdrückten. In der unverdünnten Probe (Abb. 3) wurde auch hier trotz hoher Bakterienkonzentration von etwa 2,4 x $10^{10} \mathrm{cfu} / \mathrm{ml}$ die Aktivität der Taq-Polymerase völlig gehemmt. Erst nach einer Verdünnung von 1:10 erschien die diagnostische Bande (Abb. 3). Der Nachweis war bis zu einer Verdünnung von 1:10 ${ }^{6}$ (Nr.7) möglich. Dies entsprach einer ursprünglichen Bakterienkonzentration von 1,2 x $10^{3} \mathrm{cfu} / \mathrm{ml}$. Nach der 24-stündigen Zwischenvermehrung enthielt diese Verdünnungsstufe etwa 2,4 x $10^{4} \mathrm{cfu} / \mathrm{ml}$ (Tab. 3). D. h., während vor der Zwischenvermehrung die Bakterien bei einer Konzentration von ca. $10^{4} \mathrm{cfu} / \mathrm{ml}$ nachgewiesen wurden (Abb. 2), konnte eine 20-fache niedrigere Bakteriendichte (d. h. 1,2 x $10^{3} \mathrm{cfu} / \mathrm{ml}$ ) nach der Zwischenvermehrung leicht detektiert werden (Abb. 3). 


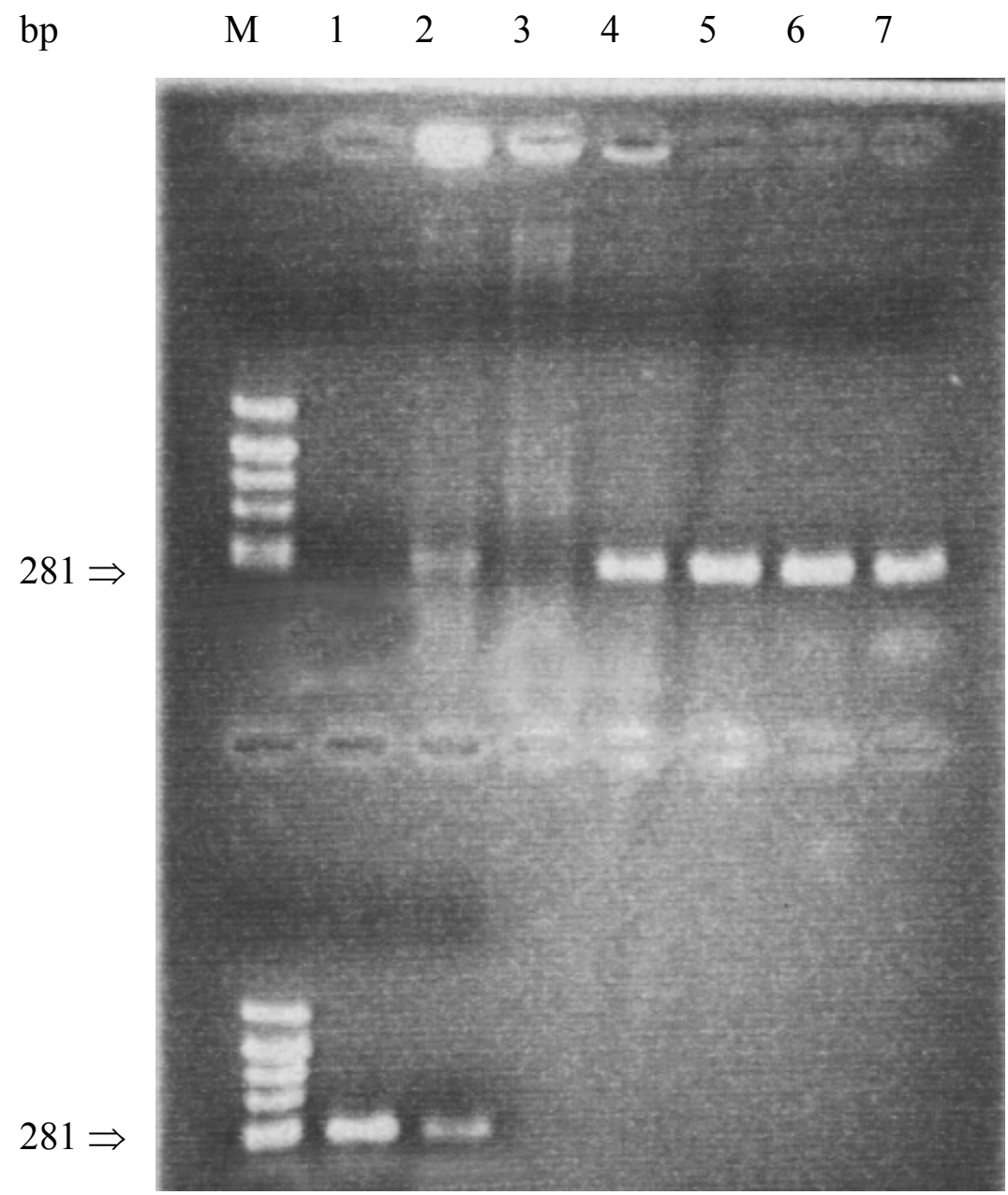

Abb.3: PCR-Nachweis von Xcp nach der Inkubation von gesunden PelargonienstengelScheibchen mit Bakteriensuspension in TC-Nährlösung M: Größenstandard pBR322/AluI 1: Negativkontrolle, 2: Positivkontrolle ( $10^{6} \mathrm{cfu} / \mathrm{ml}$ reine Bakteriensuspension) 3-9: PelletSuspensionen in den Verdünnungen $0,1: 10$ bis $1: 10^{6}$

\subsubsection{BIO-PCR von $X c p$ in planta fast 4 Jahre nach Inokulation}

Von symptomlosen Pelargonienpflanzen, die vor fast 4 Jahren mit $10 \mu 110^{3} \mathrm{cfu} / \mathrm{ml}$ Xcp inokuliert worden waren (Kapitel II), wurden Stengelproben entnommen. Drei Gramm Stengelfrischgewebe der Pelargoniensorte "Isabell" wurden in $1 \mathrm{ml}$ sterilem bidest. $\mathrm{H}_{2} \mathrm{O}$ homogenisiert, und die Verdünnungsstufen wurden auf TC-Medium und NGA-Medium ausplattiert. Danach ergab sich eine Konzentration von 2,8 x $10^{7} \mathrm{cfu} / \mathrm{g}$ Frischgewicht (oder $8,5 \times 10^{7} \mathrm{cfu} / \mathrm{ml}$ Homogenat). Die Proben wurden von Verdünnungsstufe 1(1:10) bis $5\left(1: 10^{4}\right)$ zur PCR aufgetragen. Trotz der hohen Bakterienkonzentration trat nur nach Ver- 
dünnung 1:10 ${ }^{4}$ eine leichte Bande auf. Wahrscheinlich war der Xcp-Nachweis bei den anderen Proben nicht möglich, weil die Taq-Polymerase während der PCR durch enzyminhibierende Pflanzenstoffe (z. B. phenolische Verbindungen) gestört wurde.

Die Reste des Homogenats wurden in $4 \mathrm{ml}$ TC-Lösung $\left(1,5 \times 10^{7} \mathrm{cfu} / \mathrm{ml}\right)$ bei $26{ }^{\circ} \mathrm{C}$ und 110 UPM für $24 \mathrm{~h}$ inkubiert. Dann wurden $2 \mathrm{ml}$ entnommen, bei 12.000 RPM zentrifugiert, das Pellet in $500 \mu$ l bidest. $\mathrm{H}_{2} \mathrm{O}$ aufgenommen (d. h. vierfach konzentriert) und für den PCR-Nachweis in den Verdünnungen $1: 10^{3}$ bis 1:10 $0^{7}$ eingesetzt (Abb. 4). Nach der mikrobiologischen Bestimmung enthielt $1 \mathrm{ml}$ Probe nach der Zwischenvermehrung $8 \times 10^{8}$ cfu $/ \mathrm{ml}$. D. h., in dem in $500 \mu$ l aufgenommen Pellet waren $1,6 \times 10^{9} \mathrm{cfu} / \mathrm{ml}$ enthalten, oder $40 \mu \mathrm{l}$ (für PCR) enthielten $1,5 \times 10^{8} \mathrm{cfu}$.

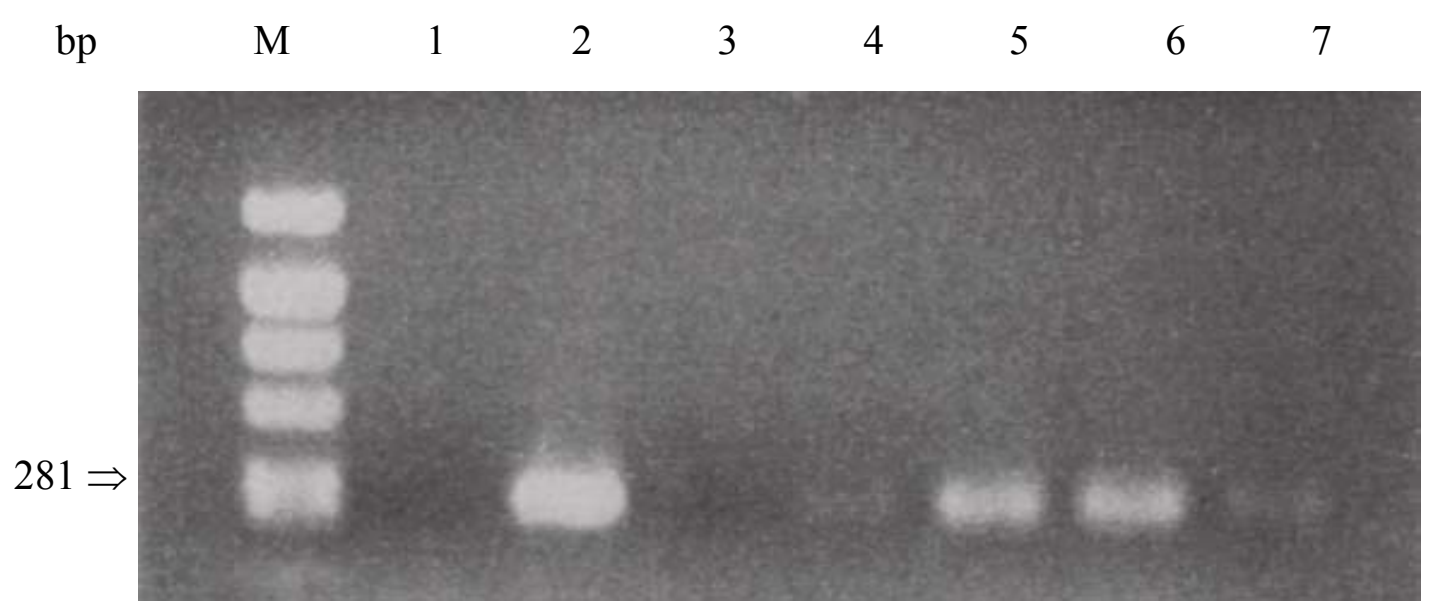

Abb. 4: Nachweis von Bakterien im Homogenat einer befallenen Pelargonienpflanze nach Zwischenvermehrung der Bakterien in TC-Lösung. M: Größenstandard pBR322/AluI, 1: Negativkontrolle, 2: Positivkontrolle $\left(10^{7} \mathrm{cfu} / \mathrm{ml}\right)$, 3: Pellet $1: 10^{3}$ verdünnt, 4: Pellet 1:10 verdünnt, 5: Pellet $1: 10^{5}$ verdünnt, 6: Pellet $1: 10^{6}$ verdünnt, 7: Pellet $1: 10^{7}$ verdünnt

Die Ergebnisse zeigen (Abb. 4), dass das suspendierte Pellet stark verdünnt werden musste $\left(1: 10^{5}\right.$ bis $\left.1: 10^{6}\right)$ um die Bakterien deutlich nachzuweisen. Die durch die PCR gewonnenen positiven Ergebnisse bestätigten damit den mikrobiologischen Nachweis. D. h., in der Probe 6 (Pellet $1: 10^{6}$ ) wurden $1,5 \times 10^{2}$ cfu noch durch ein deutliches Signal nachgewiesen, in

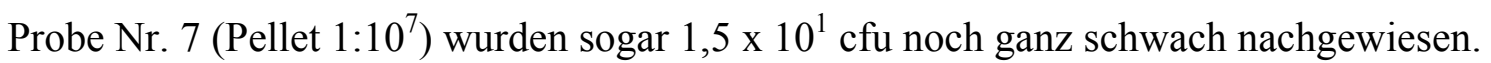




\subsubsection{Nachweis von Xcp in planta durch Homogenisation oder die Scheibchen- Methode}

Das Ziel dieses Versuches war es, Inhibitoren auszuschalten. Die vorangegangenen Versuche zeigten, dass erst nach Verdünnungen von 1:10.000 spezifische Banden auftraten, vor allem bei Bearbeitung alter Pflanzen (Abb. 4). Deswegen wurde untersucht, ob es für den PCR-Nachweis günstiger war, die Pelargonienstengel in Scheibchen zu schneiden und nicht zu homogenisieren.

Die vor 47 Monaten mit $10 \mu 110^{3} \mathrm{cfu} / \mathrm{ml}$ inokulierten Pelargonienpflanzen der Sorte "Isabell“ zeigten noch keine Symptome. Ein $6 \mathrm{~cm}$ langes Stengelstück wurde im Längsschnitt zweigeteilt. Ein Teil wurde homogenisiert und der andere Teil in Scheibchen geschnitten. Von beiden Proben wurden Verdünnungsreihen hergestellt und ausplattiert. Dabei ergab sich, dass im Homogenat $5 \times 10^{7} \mathrm{cfu} / \mathrm{ml}$ und in der Scheibchen-Lösung 4,5 x $10^{7} \mathrm{cfu} / \mathrm{ml}$ enthalten waren. Die Proben wurden dann in TC-Lösung bei $26^{\circ} \mathrm{C}$ und $110 \mathrm{UPM}$ für $48 \mathrm{~h}$ inkubiert (Zwischenvermehrung der gesuchten Bakterien) und bei 12000 RPM für 20 min abzentrifugiert, das Pellet in $500 \mu \mathrm{H}_{2} \mathrm{O}$ suspendiert, $8-10 \mathrm{~min}$ auf $100{ }^{\circ} \mathrm{C}$ erhitzt und dann für die PCR eingesetzt (Abb. 5a und Abb. 5b). Gleichzeitig wurden von der Verdünnungsstufe 4 nach der Zwischenvermehrung wieder 1:10 bis 1:10 ${ }^{4}$ Verdünnungen hergestellt und ausplattiert. Nun waren im Homogenat der Verdünnungsstufe $42,8 \times 10^{7} \mathrm{cfu} / \mathrm{ml}$ und in der Scheibchen-Lösung der Verdünnungsstufe 41,1 x $10^{8} \mathrm{cfu} / \mathrm{ml}$ enthalten.

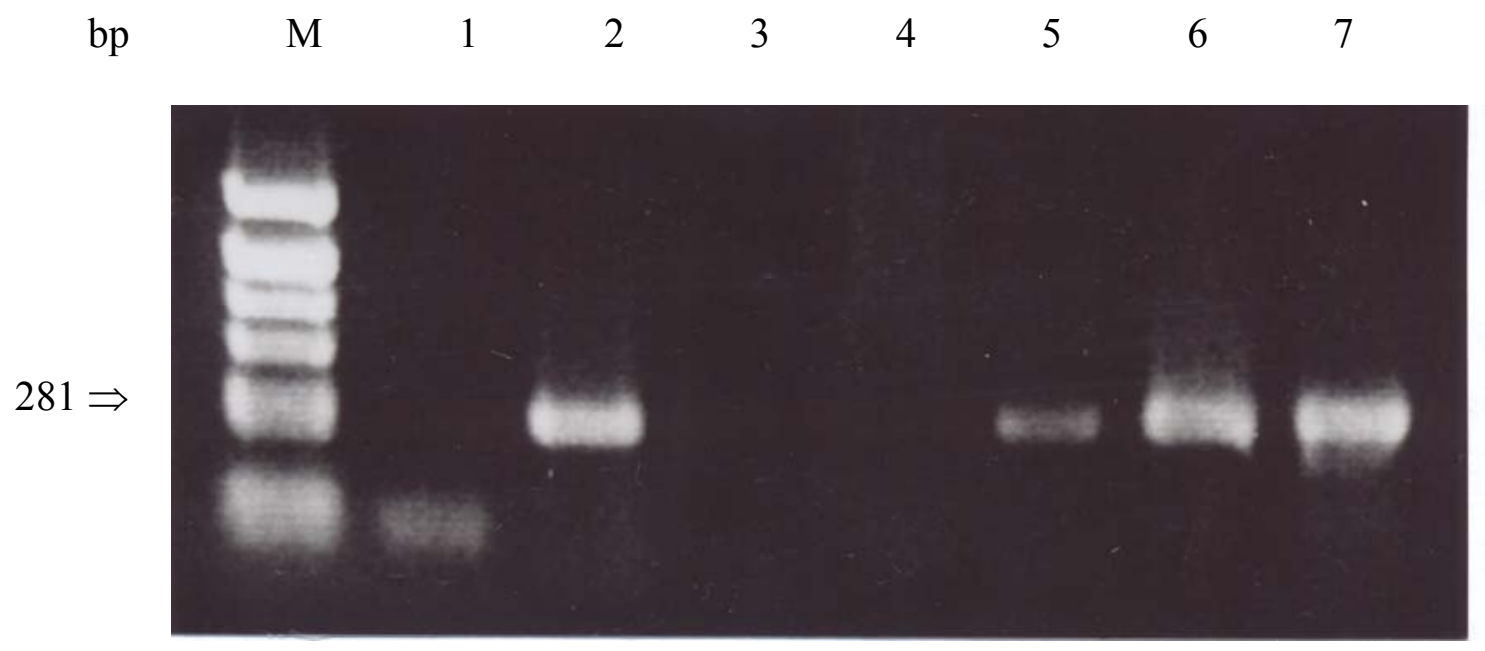

Abb. 5a: Die Stengelprobe ( $10^{3}$ "Isabell") wurde homogenisiert und $48 \mathrm{~h}$ in TC-Lösung zwischenvermehrt M: Größenstandard pBR322/AluI, 1: Negativkontrolle, 2: Positivkontrolle, 3: $1: 10^{2}$ verdünnt, $4: 1: 10^{3}$ verdünnt, $5: 1: 10^{4}$ verdünnt, $6: 1: 10^{5}$ verdünnt, $7: 1: 10^{6}$ verdünnt 


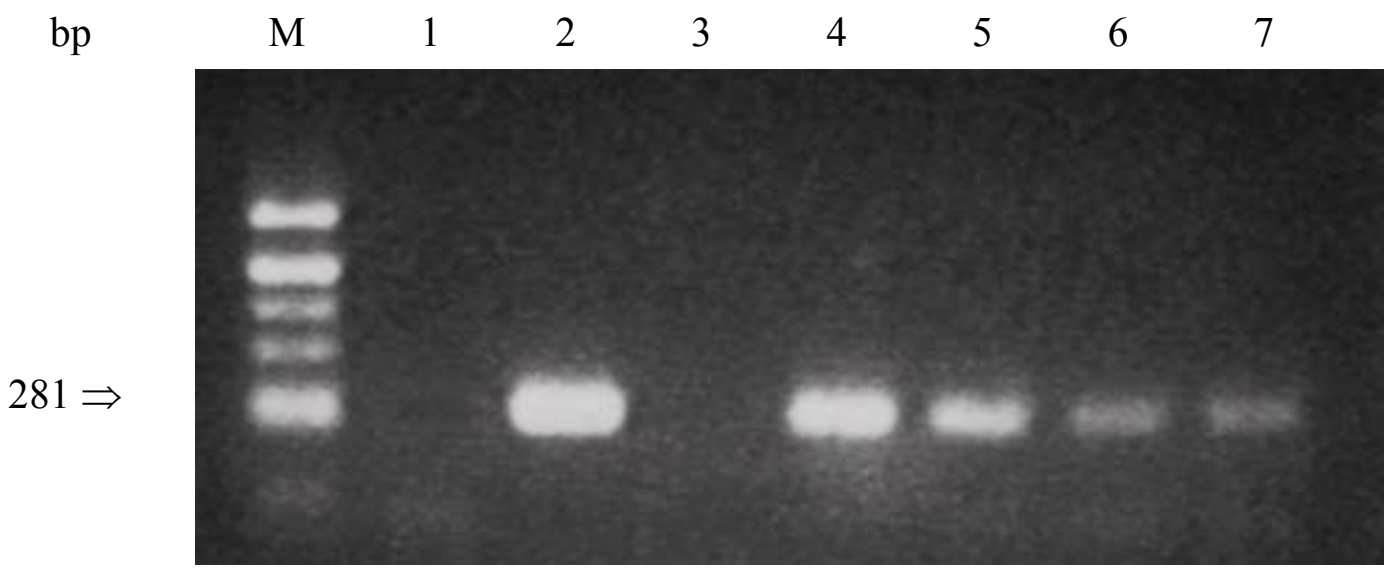

Abb. 5b: Die gleiche Probe wie in Abb. 5a wurde in dünne Scheibchen geschnitten. Danach wurde wie in Abb. 5a verfahren

Abb. 5a zeigt, dass bei der homogenisierten Probe die spezifische Bande erst nach einer Verdünnung von 1:10 ${ }^{4}$ schwach auftrat. Mit der Standard-PCR des Homogenates ohne Zwischenvermehrung war diese Bande erst nach einer Verdünnung von 1:10 5 schwach sichtbar. Dagegen zeigt Abb. 5b, dass bei der Scheibchen-Methode die spezifische Bande schon bei der Verdünnung von 1:10 $0^{3}$ auftrat und offenbar weniger Inhibitoren vorhanden waren. Die Nachweisempfindlichkeit wurde im Homogenat dadurch verringert, dass die Proben sehr stark verdünnt werden mussten. Wegen der notwendigen Verdünnungen des Pflanzenhomogenats ist es ziemlich schwer, einen schwachen latenten Befall nachzuweisen. Deswegen wurden in diesem Versuch die Proben 48 h statt 24 h in TC-Lösung inkubiert, um die Sensitivität zu verbessern.

\subsection{Eignung der Primer zum Nachweis verschiedener $X c p$-Stämme}

Die Sicherheit eines auf der PCR basierenden Nachweisverfahrens ist dann gewährleistet, wenn verschiedene Stämme des Zielorganismus nachgewiesen werden können. Die Eignung der Primer wurde deswegen mit 16 verschiedenen Xcp-Stämmen (Tab. 1) überprüft $\left(10^{6} \mathrm{cfu} / \mathrm{ml}\right)$.

Nach gelelektrophoretischer Auswertung wurde in allen Fällen bis auf Stamm 191 das Amplifikationsprodukt mit einer Fragmentgröße von $<281$ bp gebildet (Abb. 6). In späteren Versuchen wurde Stamm 191 noch einmal mit einer Bakteriensuspension von $10^{8}$ $\mathrm{cfu} / \mathrm{ml}$ getestet, wobei sich das erwartete Signal einstellte. 


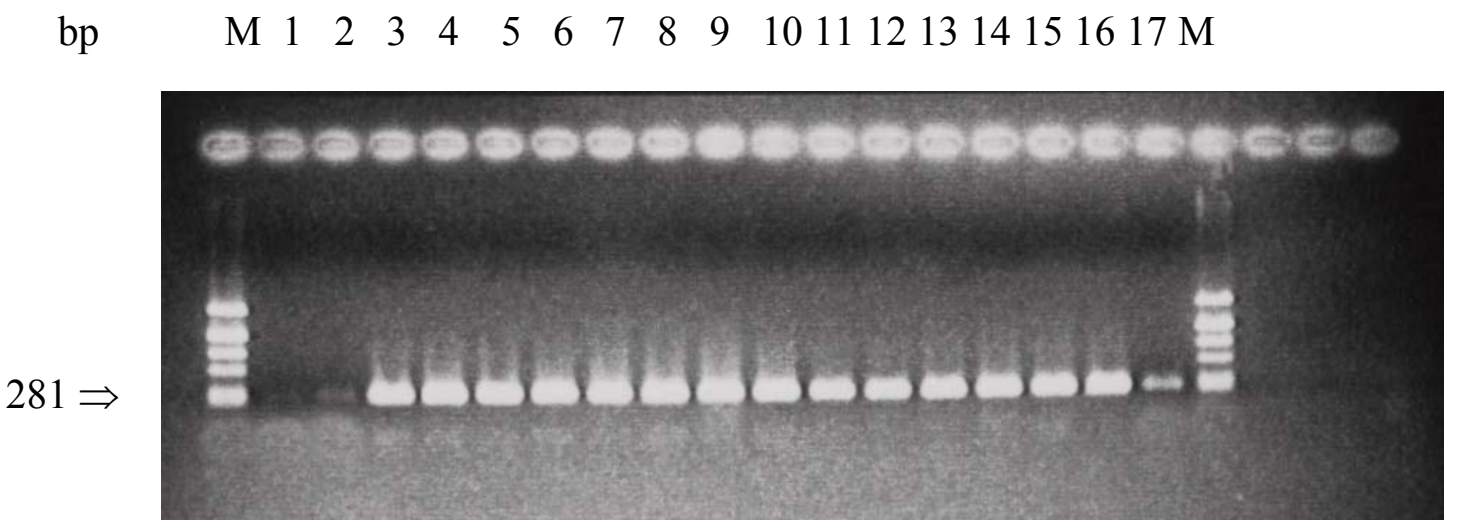

Abb. 6: PCR-Nachweis verschiedener $X c p$-Stämme mit Hilfe spezifischer Primer M: Marker pBR322/AluI, 1: Negativkontrolle, 2: 191. 3:203, 4:2503, 5:1955, 6:1957, 7:1934, $8: 2104,9: 2105,10: 2513,11: 2630,12: 2514,13: 2632,14: 2638,15: 2640,16: 192,17: 2642$

\subsection{Prüfung der Primer auf Kreuzreaktion mit anderen Bakterienarten und Xanthomonas campestris Pathovarietäten}

Die Spezifität der Amplifikation ist eine grundlegende Voraussetzung für die Praktikabilität des PCR-Tests zum Nachweis des Zielbakteriums. Für die Überprüfung der Spezifität wurden Bakterienstämme ausgewählt, die in oder an Pelargonien vorkommen können oder mit $X c p$ eng verwandt sind.

Es zeigte sich, dass die Primer nur mit Xanthomonas campestris pv. zinniae schwach kreuzreagierten. Bei allen anderen Stämmen, wie Xanthomonas campestris pv. viginicola, Xanthomonas campestris pv. malvacearum, Erwinia herbicola, Pseudomonas syringae pv. syringae und Pseudomonas fluorescens, wurden keine Signale beobachtet (Abb. 7). 


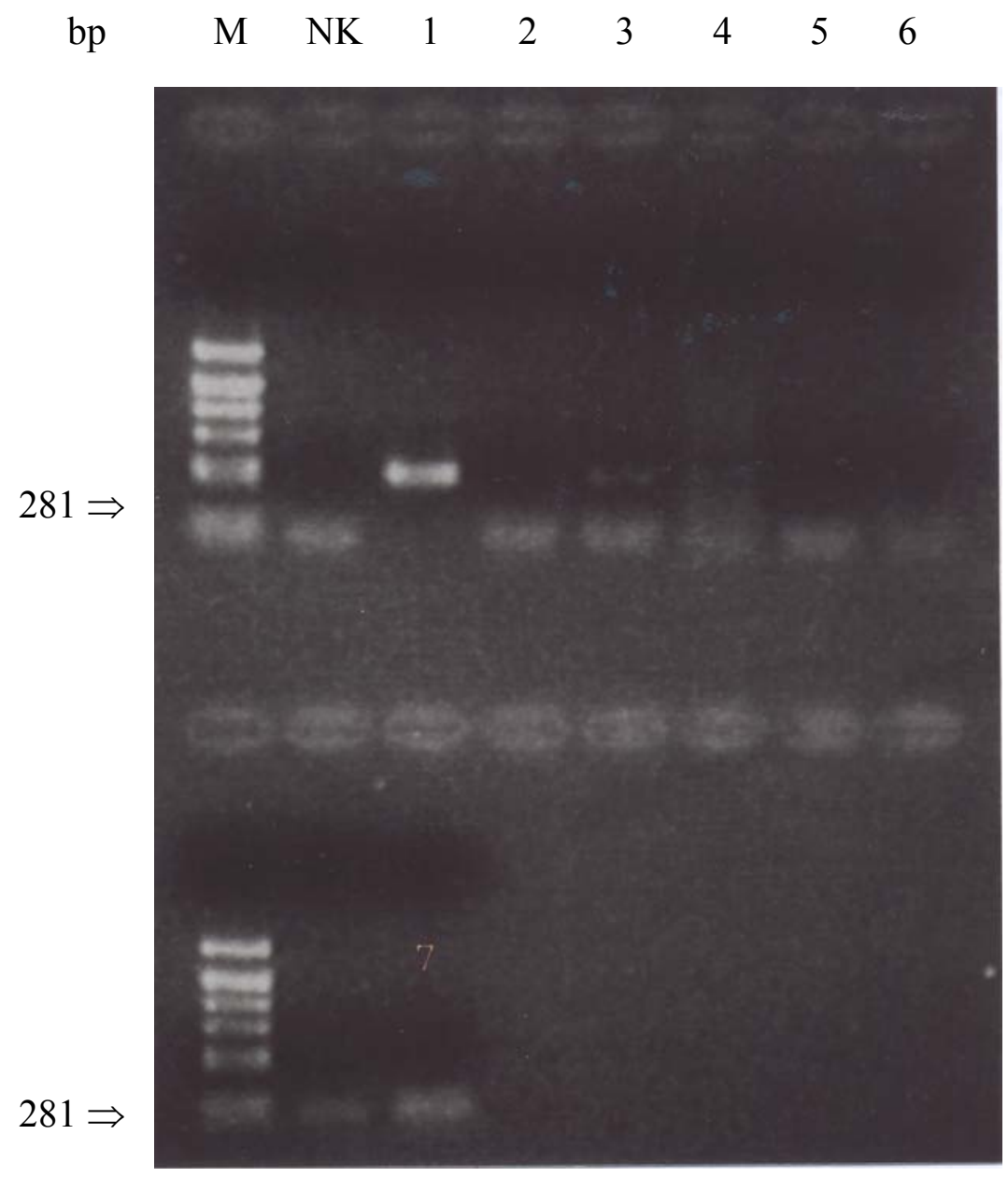

Abb. 7: Prüfung der Primer auf Kreuzreaktion mit Bakterien anderer Arten und Pathovarietäten M: Marker pBR322/AluI, N: Negativkontrolle, 1: X. campestris pv. pelargonii, 2: $X$. campestris pv. viginicola, 3: $X$. campestris pv. zinniae, 4: $X$. campestris pv. malvacearum, 5: Erwinia herbicola, 6: Pseudomonas syringae pv. syringae, 7: P. fluorescens, 


\section{DISKUSSION}

Der Einsatz von DNA-Untersuchungstechniken eröffnete insbesondere im Hinblick auf die Sensitivität neue Perspektiven für die Pathogendiagnose. Die Bedeutung der PolymeraseKettenreaktion (PCR) muss in diesem Zusammenhang ganz besonders hervorgehoben werden. Ihr Einsatz erlaubt den Nachweis minimaler Mengen an DNA, sofern geeignete Primer verfügbar sind, und ermöglicht so auch den Nachweis von nicht durch Kultivierung anzureichernden Viroiden, Viren und MLOs (,mycoplasma like organisms“) (DENG \& HIRUKI, 1991; ROBERTSON et al., 1991; YANG 1992). Mit der PolymeraseKettenreaktion und ihrer Einführung in die Pflanzenpathologie Anfang der 90iger Jahre wurden auf der PCR basierende Methoden auch zur Charakterisierung von PathogenStämmen verwendet. In jüngerer Zeit wurden PCR-Detektionssysteme zum Nachweis verschiedener pflanzenpathogener Bakterien (z. B. BERESWILL et al., 1992; HARTUNG et al., 1993; NIEPOLD, 1994; KRÄMER et al., 1998; NABIZADEH-ARDEKANI, 1999) entwickelt.

Die Polymerase-Kettenreaktion ist eine Methode, um große Mengen spezifischer DNAFragmente definierter Länge und Sequenzen in vitro enzymatisch zu synthetisieren. Sie stellte eine Alternative zur konventionellen Vermehrung von DNA in lebenden Zellen dar. Durch die Möglichkeit der in-vitro-Amplifikation entfällt die Benutzung von Restriktionsenzymen und Kloniervektoren und die umständliche Isolation der Fragmente. Die Spezifität des Systems hängt von chemisch synthetisierten Oligodesoxynucleoiden $a b$, die als Primer für das DNA-Polymerase-Enzym einen bestimmten Bereich der Targetsequenz eingrenzen. Eine weitere Besonderheit der PCR-Technik besteht darin, dass geringste Mengen des zu amplifizierenden Moleküls, im Extremfall eine einzige DNA-Matritze, ausreichen, um die Reaktion zu starten und die Nukleinsäure in nur wenigen Stunden hochgradig zu vervielfältigen. Der Erfolg einer Polymerase Kettenreaktion hängt von einer Vielzahl von Faktoren ab, die direkt oder indirekt Einfluss auf das Reaktionsgeschehen haben. Im Zentrum dieser enzymattisch katalysierten Reaktion steht eine von SAIKI et al. (1985) eingeführte, aus dem thermophilen Bakterium Thermus aquaticus isolierte, hitzestabile DNAPolymerase. 
Ziel dieser Arbeit war es, den Nachweis von Xanthomonas campestris pv. pelargonii (= Xсp) nicht nur aus Reinkulturen sondern auch aus latent infizierten Pelargonienpflanzen mit der PCR zu überprüfen.

\subsection{Vergleich der verschiedenen Primer}

Molekularbiologisch wurden mit Xcp bisher nur wenige Untersuchungen durchgeführt. Zum Nachweis von $X c p$ mit der PCR-Technik wurden 3 verschiedene Primer-Paare beschrieben (MANULIS et al. 1994; SULZINSKI et al., 1995, 1996 und 1997; KRÄMER et al., 1998), wobei zuerst SULZINSKI et al. (1996) Xcp in Pflanzenextrakten nachweisen konnten.

MANULIS et al. (1994) charakterisierten zunächst Xcp DNA durch zufällig amplifizierte PCR ("random amplified PCR") und später durch Pathovar-spezifische Primer. Die Autoren testeten 42 verschiedene Primer-Paare. Drei Paare lieferten mit allen geprüften 53 XсpStämmen identische Amplifikationsmuster. Die Xcp-Banden-Muster unterschieden sich von denjenigen aller anderen 46 Xanthomonas-Stämme. Ein spezifisches Fragment von 1,2-kb kam nur bei den $X c p$-Stämmen vor. Dieses Fragment wurde kloniert und als diagnostische Sonde getestet. Die Sonde hybridisierte mit allen 53 geprüften Xcp-Stämmen, aber nicht mit den anderen 46 Xanthomonas-Stämmen. Die Sequenz der terminalen Enden des 1,2 kb-Fragmentes diente zur Entwicklung eines Primer-Paares von 18 Nukleotiden. Das so gewonnene Primer-Paar amplifizierte dasselbe 1,2-kb DNA-Fragment von allen geprüften $53 X c p$-Stämmen, aber nicht von den anderen Xanthomonaden. Ein ähnliches Verfahren wurde auch zur Entwicklung von spezifischen Primern für die PCR-Diagnose anderer phytopathogener Bakterien eingesetzt (MANULIS et al., 2002).

SULZINSKI et al. (1996) entwickelten das Primer-Paar XcpM1/XcpM2 unter Verwendung der DNA-Präparationen von 22 geographisch unterschiedlichen Xcp-Stämmen. Mit diesem Olinucleotid-Primer-Paar XcpM1 (5'-ACGCGCTACCAAAAGGCAAAGAG-3') und XcpM2 (5'-GATCTGCGGTTGTCCTGAAGATTGG-3') wurde eine Haupt-DNABande von 197 bp amplifiziert, während keine Hauptbanden bei 12 anderen X. campestrisPathovarietäten erzeugt wurden. GLICK et al. (2002) derselben Arbeitsgruppe entwickelten noch 2 weitere Primer-Paare: ein Paar spezifisch für die Amplifikation eines 822 bp großen DNA-Fragmentes von Ralstonia solanacearum und ein Primer-Paar als internen Standard, welches eine 494 bp Region der 18s rRNA von Geranium amplifiziert. Mit dem internen Standard, können falsche negative Ergebnisse, die durch Inhibitoren des PCR- 
Verfahrens verursacht werden, leicht entdeckt werden, weil die spezifische Bande in einem Pflanzenextrakt aus Pelargonien in jedem Fall erscheinen muss (Positiv-Kontrolle).

KRÄMER et al. (1998) versuchten zunächst, Xcp mit 60 geprüften Zufalls-Primern mit der RAPD-Technik $\mathrm{zu}$ charakterisieren und von anderen Xanthomonas campestrisPathovarietäten zu differenzieren. Unter den eingesetzten Primern lieferte der Primer OPA09 ein für $X c p$ charakteristisches Amplifikationsmuster. In diesem Bandenmuster trat ein pathovarspezifisches, markantes Fragment mit einer Größe von 340 bp auf (KRÄMER, 1994). Dieses Amplifikat wurde isoliert, amplifiziert, kloniert und sequenziert. Aus den Sequenzendaten wurden anschließend verschiedene Primer-Paare konstruiert und synthetisiert. Bei der Prüfung ihrer Spezifität wurden die besten Ergebnisse mit einen Primer-Paar erzielt, welches ein 246 bp großes Produkt amplifizierte (KRÄMER et al., 1998). Das auf diese Weise entwickelte Primer-Paar wurde in allen PCR-Experimenten dieser Arbeit eingesetzt und hat folgende Basensequenzen: GAGTGTCCAGTGGCAAGC (Primer XCP1) und Reverse Primer GTTGCTGCCTCTTCCTGC (Primer XCP2).

\subsection{Vergleich der DNA-Extraktion oder des Bakterienaufschlusses bei verschiede- nen Verfahren}

In der Literatur werden zahlreiche Methoden zur DNA-Isolierung aus Pflanzenmaterial beschrieben. In den meisten Fällen handelt es sich dabei um sehr zeitaufwendige Verfahren, bei denen zusätzlich große Mengen an giftigen Chemikalien wie Phenol, Ethidiumbromid u. a. anfallen. Große Mengen an Polysacchariden und sekundären Metaboliten wie Polyphenol, welche die Taq-Polymerase hemmen, zwingen zu umständlichen Verfahren, die multiple Arbeitsschritte beinhalten. Auf Grund der unterschiedlichen Strukturen und Funktionen globulärer Proteine unterliegen Enzyme mehr oder weniger der Repression durch Inhibitoren wie phenolische Verbindungen. Es ist bekannt, dass die Aktivität der Taq-Polymerase schon durch geringe Mengen sekundärer Pflanzenstoffe stark gehemmt wird.

In dieser Arbeit wurde versucht, die DNA-Extraktion nach KRÄMER et al. (1998) durchzuführen. Durch $X c p$ befallenes Gewebe wurde in einer Nährbouillon über Nacht bei $25^{\circ} \mathrm{C}$ geschüttelt. Dann wurde abzentrifugiert und das Pellet in $200 \mu 1$ TE-Puffer für 10 min bei $100{ }^{\circ} \mathrm{C}$ gekocht. Anschließend wurde mit $1 \mathrm{M} \mathrm{NaOH}$ und $1 \mathrm{M}$ TRIS-HCI behandelt. DE BRUIJN (1987) extrahierte die DNA von Xcp mit Phenol-Chloroform. Diese Methode ist allerdings sehr zeitaufwendig. Es ist nicht möglich, mit vielen Proben zu arbeiten (SUL- 
ZINSKI et al., 1996). In unseren Untersuchungen konnten wir vor allem niedrige Bakterienkonzentrationen von $X c p$ nicht detektieren. Deswegen wurde diese Methode als ungeeignet angesehen, aus latent befallenen Pflanzen DNA zu isolieren. SULZINSKI et al. (1997) entwickelten deswegen ein Protokoll für eine schnelle (10 min) Extraktionsmethode, um die pflanzenbürtigen Amplifikations-Inhibitoren zu eliminieren. Sie extrahierten die DNA aus dem Pflanzenhomogenat (in Wasser oder $10 \mathrm{mM}$ Tris-HCl, $\mathrm{pH}$ 8,0) mit dem kommerziellen "Gene Releaser" durch kurze Erhitzung mit Mikrowellen. Die so präparierte Nukleinsäure wurde direkt als Matrize für eine PCR-Amplifikation mit Primern verwendet. Eine BIO-PCR war nicht notwendig, so dass der Erregernachweis innerhalb von $3 \mathrm{~h}$ durchgeführt werden konnte.

In den hier beschriebenen Versuchen wurde auf eine DNA-Extraktion verzichtet. Da ein "Gene Releaser" nicht zur Verfügung stand, wurden die Proben nur 10 min auf $100{ }^{\circ} \mathrm{C}$ erhitzt. Dann wurden die Komponenten des PCR-Ansatzes (Tab. 2) hinzugegeben. Mit dieser einfachen Methode wurde eine hohe Nachweisempfindlichkeit erreicht (4.3).

\subsection{Nachweisempfindlichkeit}

\section{Nachweisempfindlichkeit mit Reinkulturen:}

In unseren Versuchen wurde für die Bestimmung der Nachweisgrenze in vitro zunächst eine Bakteriensuspension mit einer definierten Zahl Kolonien bildender Einheiten (cfu/ml) aus Xcp-Kulturen hergestellt, in 10er Schritten verdünnt und direkt für die PCR verwendet. Es konnte gezeigt werden, dass eine erfolgreiche Amplifikation der Zielsequenz mittels PCR möglich war, ohne die DNA aus Suspensionskulturen zu isolieren.

Die Arbeitsgruppe KRÄMER konnte mit dem dort entwickelten Primer-Paar, das auch von uns verwendet wurde, $10^{3} \mathrm{cfu} / \mathrm{ml}$ nachweisen (KRÄMER, mündliche Mitteilung). Die in unseren Versuchen ermittelte Nachweisgrenze von $X c p$ in Reinkulturen lag ebenfalls bei $10^{3} \mathrm{cfu} / \mathrm{ml}$, d. h., im Probenvolumen von $40 \mu \mathrm{l}$ aus einer Bakteriensuspension von $10^{3}$ cfu/ml konnten die Bakterien (absolut nur 40 cfu pro PCR Ansatz) mit schwachem Signal nachgewiesen werden, ohne die DNA aus den Suspensionskulturen zu isolieren (Abb. 1).

MANULIS et al. (1994) konnten mit ihrem Primer-Paar zwischen 10 - 50 Xcp-Zellen nachweisen. Im Vergleich mit der DAS-ELISA-Methode, die für Xcp eine Nachweisgrenze von $10^{3}-10^{4} \mathrm{cfu} / \mathrm{ml}$ erlaubt (Kapitel III, BERKELMANN et al., 1993), können mit der PCR noch geringere Bakterienmengen von Xcp nachgewiesen werden. Auch nach NAMETH et 
al. (1999) ist PCR die einzige Diagnosemethode, die minimale Bakterienkonzentrationen von Xcp (latenter Befall) in verdächtigen Pflanzen nachweisen kann. Eine ähnliche Nachweisempfindlichkeit ermittelten NABIZADEH-ARDEKANI et al. (1997b) in Reinkulturen von Pseudomonas syringae pv. tomato mit $10^{3} \mathrm{cfu} / \mathrm{ml}$.

Nach NIEPOLD (1994) lag die Grenze der nachgewiesenen Zellkonzentration von Erwinia caratovora subsp. atroseptica mit der PCR-Methode bei $10^{4} \mathrm{cfu} / \mathrm{ml}$ und war damit niedriger als im ELISA-Test $\left(10^{5} \mathrm{cfu} / \mathrm{ml}\right)$ und ebenso in routinemäßig durchgeführten IF-Tests (ca. $10^{4} \mathrm{cfu} / \mathrm{ml}$ ) oder bei der Immunofluoreszenz-Kolonienfärbung (VAN VUURDE und ROOYEN, 1990).

\section{Nachweisempfindlichkeit mit Pflanzenhomogenat:}

In unseren Untersuchungen wurde die Sensitivität des PCR-Nachweises in Gegenwart von Pflanzenhomogenaten ermittelt, indem parallel auch ein direkter Nachweis der Bakterien im Probenmaterial durch Verdünnungsreihen und Ausplattieren durchgeführt wurde. Dazu wurden Xcp-Zellen in einem Pflanzenhomogenat von gesunden Pelargonienstengeln suspendiert, in 10er-Stufen mit bidest- $\mathrm{H}_{2} \mathrm{O}$ verdünnt und mit jeder Verdünnungsstufe die PCR durchgeführt. Bei Verdünnungen gelang durch die PCR ein Nachweis herunter bis zu $\mathbf{1 0}^{\mathbf{4}}$ cfu/ml (Abb. 2). Da das Stengelhomogenat 1:10 oder 1:100 verdünnt werden musste, um die Inhibitoren der PCR durch Verdünnung unwirksam zu machen, kann die Nachweisempfindlichkeit der PCR-Tests um ein bis zwei Zehnerpotenzen verschlechtert werden, wenn die gesuchten Bakterien schon im Homogenat nur in sehr geringen Konzentrationen vorkommen. In diesen Fällen muss wegen der notwendigen Verdünnung des Pflanzenhomogenates ein erheblicher Sensitivitätsverlust in Kauf genommen werden.

SULZINSKI et al. (1996) konnten mit dem Primer-Paar XcpM1/XcpM2 630 - 6.300 cfu Xсp aus erkrankten Geranien detektieren, nach einer Blot-Hybridisierung mit einer pathovar-spezifischen biotinylierten Sonde konnten sogar noch 63 - 630 cfu nachgewiesen werden.

\section{Nachweisempfindlichkeit mit der BIO-PCR:}

BIO-PCR bedeutet eine Vermehrung der Bakterien vor der PCR auf einer Nährmedium (SCHAAD et al., 1995). Unsere Untersuchungen wurden ähnlich wie bei SCHAAD durchgeführt. Allerdings wurde die Vermehrung der Bakterien nicht auf einem generellen Nährmedium, sondern in einer semi-selektiven Nährlösung (TC-Lösung) durchgeführt. 
Diese Methode ermöglicht eine erhöhte Empfindlichkeit wegen der hohen Selektivität der TC-Lösung. So wird z. B. das Wachstum der saprophytischen Bakterien ausgeschlossen, wodurch falsch positive Ergebnissen weitgehend verhindert werden. SCHAAD et al. (1995) konnten mit der BIO-PCR zwei Pseudomonas syringae pv. phaseolicola Zellen pro ml nachweisen.

Um die Inhibitoren der PCR unwirksam zu machen, musste das Homogenat bis 1:100 verdünnt werden. Wenn aber die gesuchten Bakterien bereits im Homogenat in sehr geringen Konzentrationen vorkommen, kann diese Verdünnung zu einem Sensitivitätsverlust führen. Bei den latent befallenen Pflanzen ohne DNA-Extraktion ist es daher ziemlich schwer, Xcp nachzuweisen. Deswegen wurde hier das BIO-PCR-Verfahren durchgeführt, um die Nachweisempfindlichkeit zu verbessern. NABIZADEH-ARDEKANI (1999) konnte mit der BIO-PCR $10^{2}$ Pseudomonas syringae pv. tomato Zellen pro $\mathrm{ml}$ aus Saatgut nachweisen. In den hier durchgeführten Untersuchungen waren $1,2 \times 10^{3} \mathrm{cfu} / \mathrm{ml}$ (oder $5 \times 10^{1}$ pro PCR-Ansatz) aus einem latent infizierten Stengel nachweisbar (Abb. 3). Ohne diese Verfahren lag die Nachweisgrenze infizierter Pflanzen bei $10^{4} \mathrm{cfu} / \mathrm{ml}$ (Abb. 2).

Wenn eine 24- oder 48-stündige Zwischenvermehrung in Nutrien Broth eingeschaltet wurde, konnte von SULZINSKI et al., (1998) in Pelargonien-Proben gleich nach der Inokulation noch 1 cfu nachgewiesen werden. Durch Anreicherung der Bakterien auf SPA (BIOPCR) erhöhten auch ZIMMERMANN et al. (2001) die Nachweisempfindlichkeit von Xanthomonas fragariae. Sie stellen fest, dass durch die PCR ca. 2 × $10^{4} \mathrm{cfu} / \mathrm{ml}$ Blatthomogenat detektiert werden konnten, während BIO-PCR die Nachweisgrenze deutlich verbesserte und im Bereich von 2 - $200 \mathrm{cfu} / \mathrm{ml}$ lag.

\section{BIO-PCR Homogenat oder Scheibchen-Methode:}

Die BIO-PCR ist möglicherweise ein geeignetes Verfahren, um latenten Befall mit Xcp nachzuweisen. Zwei Punkte sollten beachtet werden. Wenn man vor allem von latent befallenen Pflanzen große Proben (z. B. 4 - 5 cm lange Stengelstücke) nimmt, muss sehr stark verdünnt werden um die Inhibitoren (Pflanzeninhaltstoffe) der PCR durch Verdünnung unwirksam zu machen. Sekundäre Pflanzeninhaltsstoffe wie Polyphenol (JOHN, 1992; TSAI und OLSON, 1992) und Polysaccharide (DEMKE \& ADAMS, 1992) werden als mögliche DNA-Polymerase-Inhibitoren angesehen. Ein zweiter Punkt ist die Frage, ob die Proben zu homogenisieren sind oder die Scheibchen-Methode anzuwenden ist. Unsere Untersuchungen zeigten, dass die Sensitivität bei der Scheibchen-Methode viel höher war als beim Homogenisieren der Proben (Abb. 5b). 


\subsection{Kreuzreaktionen}

Für die Sicherheit eines PCR-Nachweises spielen mögliche Kreuzreaktionen mit anderen Bakterien eine große Rolle.

MANULIS et al. (1994) stellten fest, dass ihr eingesetztes Primer-Paar dasselbe 1,2-kb DNA-Fragment von allen geprüften $53 \mathrm{Xcp}$-Stämmen amplifizierte, aber nicht von den anderen Xanthomonaden. Auch isolierte DNA von saprophytischen, an Geranium vorkommenden Bakterien hybridisierte nicht mit dem 1,2 kb DNA-Fragment. SULZINSKI et al. (1996) berichten, dass bei Verwendung des Primer-Paars XcpM1/XcpM2 zahlreiche $X$. campestris-Pathovarietäten, wie begoniae, campestris, carotae, citri, citrumelo, juglandis, malvacearum, manihotis, phaseoli, pruni, vesicatoria und vitians, keine Kreuzreaktionen lieferten. Ebenso wurden mit demselben Primer-Paar weder für Corynebacterium fascians noch für Pseudomonas cichorii, die auch als Geranienpathogene vorkommen, Amplifikationsprodukte gefunden.

Auch die mit ERIC- und REP-Primern erhaltenen Fingerabdrücke erlaubten eine Unterscheidung der Xanthomonas campestris pv. pelargonii-Stämme von den anderen untersuchten Pathovarietäten citrumelo, citri, begoniae, vitians B und C, phaseoli, campestris, manihotis, juglandis, carotae und pruni (SULZINSKI et al., 1995). Mit dem Primer-Paar XcpM1/XcpM2 konnten sogar die nahe verwandten Pathovarietäten X. c pv. pelargonii und X. c. pv. hederae sowie Acidovorax unterschieden werden (SULZINSKI, 2001). Ebenso wenig wurden die phytopathogenen Bakterien Corynebacterium fascians und Pseudomonas cichorii durch diese Primer erfasst (SULZINSKI et al., 1997).

Auch bei dem in dieser Arbeit verwendeten Primer-Paar XCP1/XCP2 wurde die Spezifität gegenüber anderen Bakterienstämmen überprüft. Bei X. c. pv. viginicola, X. c. pv. malvacearum, E. herbicola, P. fluorescens wurde kein Signal beobachtet, während leichte Kreuzreaktionen nur bei $X$. c. pv. zinniae auftraten (Abb. 7). Von den anderen Arbeitsgruppen wurde eine Kreuzreaktion gegenüber X. c. pv. zinniae u. W. nicht überprüft. Über das Vorkommen dieses Pathogens auf Geranien berichtete FRANKE (1994). Wie häufig dies der Fall ist, ist bisher noch unbekannt. Weitere Untersuchungen müssten zeigten, ob die schwach positive Reaktion mit dem Primer-Paar von KRÄMER und evtl. auch mit den beiden anderen Primer-Paaren in Praxis-nahen Routine-Test zu falsch-positiven Bewertungen führen kann. 


\subsection{Vergleich verschiedener $X c p$-Stämme}

Neben der Empfindlichkeit der PCR und der Spezifität der Primer wird die Sicherheit der Nachweissystems besonders von der Breite der erfassbaren Xcp-Stämme beeinflusst, die im PCR-Test ein positives Ergebnis ergeben. Um die Eignung der Primer zu überprüfen, wurden in diesen Untersuchungen $16 \mathrm{Xcp}$-Stämme unterschiedlicher Herkunft untersucht. Im PCR-Nachweis lieferten alle 16 Stämme ein positives Signal (Abb. 6). Auch MANULIS et al. (1994) konnten mit dem von ihnen entwickelten Primer-Paar bei allen getesteten $53 X c p$-Stämmen ein positives Signal feststellen, während alle anderen geprüften 46 Xanthomonas-Stämme negativ reagierten. Ebenso berichteten SULZINSKI et al. (1996), dass das eingesetzte Primer-Paar mit 22 verschiedenen Xcp-Stämmen ein positives Signal lieferte, aber nicht mit 12 anderen Xanthomonas-Pathovarietäten.

\subsection{Vor- und Nachteile der in dieser Arbeit eingesetzten Primer und Extrak- tionmethode gegenüber den anderen publizierten Verfahren}

Ein direkter Vergleich der Primer wurde in dieser Arbeit nicht durchgeführt. Ein Vergleich der Literaturdaten ergibt, dass die Primer von MANULIS und SULZINSKI mit einer gröBeren Zahl von Bakterien-Stämmen auf Kreuzreaktionen getestet wurden als in dieser Arbeit, obwohl $X$. c. pv. zinniae nicht getestet wurde. In Bezug auf dieses Kriterium ergeben sich somit keine deutlichen Unterschiede zwischen den Primern. Die Nachweisempfindlichkeit mit den hier benutzten Primern von KRÄMER lag bei Reinkulturen bei 40 cfu/PCR-Ansatz und im Pflanzenextrakt bei $400 \mathrm{cfu} /$ PCR-Ansatz. Ähnlich detektierten MANULIS et al. (1994) 10 - 50 cfu/PCR-Ansatz in Reinkulturen und SULZINSKI et al. (1996) 630 - $6300 \mathrm{cfu} /$ PCR-Ansatz im Pflanzenhomogenat. Demnach scheint das PrimerPaar von KRÄMER einen etwas empfindlicheren Xcp-Nachweis zu erlauben als dasjenige von SULZINSKI et al. (1996). Ziemlich sicher scheint zu sein, dass alle 3 Primer-Paare gegenüber allen geprüften $X c p$-Stämme positiv reagierten.

Der Vorteil gegenüber anderen Autoren besteht darin, dass der Nachweis der Bakterien hier aus Pflanzengewebe direkt ohne DNA-Extraktion durchgeführt werden konnte. Der Nachteil war, dass Inhibitoren des PCR-Verfahrens, insbesondere der Taq-Polymerase, nicht ausgeschaltet wurden. Bei den Verfahren von SULZINSKI werden aber diese Inhibitoren offenbar auch nicht besser ausgeschaltet. In anderen Arbeiten wurden die Bakterien in einer generellen Nährlösung zwischenvermehrt. Dabei besteht die Gefahr, dass das 
Wachstum von Saprophyten und Kontaminanten auch stark gefördert wird, während in der hier durchgeführten Arbeit die Anreicherung in TC-Lösung stattfand. Dies hat den Vorteil, dass das Wachstum der saprophytischen Bakterien eliminiert werden kann.

\subsection{Einsatz der PCR für Routine-Tests, Vor- und Nachteile gegenüber anderen Methoden}

Da jetzt ein gutes semiselektives Medium (TC-Medium) für die BIO-PCR verfügbar ist, könnte die BIO-PCR in Routinetests eingesetzt werden. Durch die Anreicherung der Bakterien im TC-Medium wurde die Nachweisempfindlichkeit erheblich erhöht. Im Gegensatz zum ELISA besitzt die BIO-PCR eine sehr gute Reproduzierbarkeit. Der Nachteil besteht darin, dass mit der BIO-PCR große Probenmengen, wie beim ELISA, nicht bearbeitet werden können und die Kontaminationsgefahr in der PCR viel höher ist als beim ELISA. Ein Vorteil der BIO-PCR besteht darin, dass ohne DNA-Extraktion Xcp in planta nachgewesen werden kann, während Frau KRÄMER (Aschersleben) für dieselben Primer-Paare DNA extrahieren musste, obwohl hier auch eine Zwischenvermehrung stattfand.

Sowohl ELISA als auch BIO-PCR sind nicht so empfindlich wie das Ausplattieren auf dem von uns hergestellten semiselektiven Medium. Das semiselektive Medium besitzt eine sehr hohe Selektivität, eine schnelle Durchführbarkeit und ist sehr kostengünstig. 


\section{ZUSAMMENFASSUNG}

1. Das Ziel der Arbeit war der empfindliche Nachweis von Xanthomonas campestris pv. pelargonii $(X c p)$ durch Einsatz der Polymerase-Kettenreaktion (PCR). Zu diesem Zweck wurden die von KRÄMER (1998) beschriebenen Primer XCP1 und XCP2 eingesetzt.

2. Der PCR-Nachweis nach DNA-Extraktion aus Reinkulturen war wenig sensitiv $\left(10^{7}\right.$ $\mathrm{cfu} / \mathrm{ml}$ ), und bei Anwendung der Methode für infizierte Pflanzen wurde überhaupt kein positives Signal gefunden.

3. Dagegen betrug die Nachweisgrenze von direkt im Ansatz lysierten Xcp-Reinkulturen $10^{3} \mathrm{cfu} / \mathrm{ml}$.

4. Für den in planta-Nachweis von $X c p$ wurde mit Homogenaten aus gesunden Pelargonienstengeln unter Zugabe von $X c p$-Suspensionen definierter Konzentrationen gearbeitet. Dabei ergab sich, dass die Amplifikation der diagnostischen Bande erst nach einer 1:10fachen Verdünnung der Probe möglich war, um die Wirkung pflanzlicher Inhibitoren auf die Taq-Polymerase (von Fa. BIOMETRA) auszuschalten. Die Nachweisgrenze lag bei $1 \mathbf{1 0}^{4} \mathrm{cfu} / \mathrm{g}$ Frischgewicht. Bei Verwendung der Taq-Polymerase von der Fa. Qiagen musste das Pflanzenextrakt 1:100 verdünnt werden, und die Nachweisgrenze lag bei $\mathbf{1 0}^{3} \mathrm{cfu} / \mathrm{g}$ Frischgewicht.

5. Mit der BIO-PCR, d. h. 24-stündiger Zwischenvermehrung der Bakterien in TCLösung, ergab sich im Gemisch mit Pflanzenhomogenat eine Nachweisempfindlichkeit von $50 \mathrm{cfu}$, entsprechend $1,2 \times 10^{3} \mathrm{cfu} / \mathrm{ml}$.

6. In symptomlosen, latent befallenen Pelargonienpflanzen, die vor 4 Jahren inokuliert worden waren, konnten die Bakterien durch die BIO-PCR nachgewiesen werden.

7. Wenn zum Bakteriennachweis in planta die Pelargonienstengel entweder homogenisiert oder in Scheibchen zerschnitten wurden, mussten die Proben aus dem Homogenat stärker verdünnt werden, um die Wirkung pflanzlicher Hemmstoffe auszuschalten. Mit der 
Scheibchen-Methode konnten deswegen geringe Bakterienkonzentrationen leichter nachgewiesen werden.

8. Der PCR-Nachweis wurde mit Reinkulturen von 16 virulenten $\boldsymbol{X c p}$-Stämmen unterschiedlicher Herkunft überprüft. Dabei lieferten alle Stämme positive Signale.

9. Kreuzreaktionen traten nur schwach gegen $X$. campestris pv. zinniae auf, aber nicht gegen $X$. campestris pv. viginicola, X. campestris pv. malvacearum, Erwinia herbicola, Pseudomonas syringae pv. syringae und Pseudomonas fluorescens.

10. Die PCR-Methode könnte in Routinetests auf Grund der sehr hohen Nachweisempfindlichkeit, schnellen Testdurchführung und guten Reproduzierbarkeit (im Gegensatz zum ELISA) eingesetzt werden. 


\section{Kapitel V}

\section{ZUSAMMENFASSUNG}

1) Zum schnellen und sicheren Nachweis von Xanthomonas campestris pv. pelargonii $(=X c p)$ in Pflanzen wurden 2 neue semiselektive Nährmedien entwickelt:

Das Tween-Cellobiose-(TC)-Medium mit den Antibiotika Cephalexin, 5-Fluorouracil, Tobramycin und Cycloheximid schloss die geprüften unerwünschten Begleitbakterien vollständig aus, während das MD5A-Medium mit Cephalexin, Bacitracin und Aztreonam ein gewisses Wachstum anderer Bakterien erlaubte, aber ohne das karzinogene 5-Fluorouracil auskam.

2) Für die Untersuchung der Latenz in einem Langzeitversuch von 68 Monaten wurden die Pelargonien-Sorten „Rosario“ und „Isabell“ am Stengel mit $10 \mu \mathrm{l}$ einer Bakteriensuspension von 3 verschiedenen Konzentrationen $\left(10^{3}, 10^{4}\right.$ und $\left.10^{5} \mathrm{cfu} / \mathrm{ml}\right)$ inokuliert und die Pflanzen je zur Hälfte bei $15{ }^{\circ} \mathrm{C}$ und bei $25{ }^{\circ} \mathrm{C}$ aufgestellt. Bei $25{ }^{\circ} \mathrm{C}$ erkrankten die Pflanzen zunächst innerhalb von 6 Monaten viel schneller als bei $15{ }^{\circ} \mathrm{C}$. Bei $15{ }^{\circ} \mathrm{C}$ erfolgte die Erkrankung zwar langsamer, aber kontinuierlicher, so dass am Ende des Versuches (nach 68 Monaten) von den bei $15{ }^{\circ} \mathbf{C}$ gehaltenen Pflanzen deutlich mehr erkrankt waren. D. h., die niedrige Temperatur von $15^{\circ} \mathrm{C}$ förderte die Latenz. Bei den wärmer gehaltenen Pflanzen starben die inokulierten Bakterien in denjenigen Pflanzen, in denen sie nicht innerhalb von 11 Monaten eine Erkrankung ausgelöst hatten, ganz ab.

Im Versuchszeitraum ergab sich eine maximale Latenzperiode von 57 Monaten, d. h., in einer Pflanze konnten die Bakterien, ohne Krankheitssymptome auszulösen, fast 5 Jahre unerkannt überleben. In latent befallenen Stengeln kamen $10^{2}-10^{3} \mathrm{cfu} / \mathrm{g}$ Frischgewicht vor. Erst ab $10^{8} \mathrm{cfu} / \mathrm{g}$ erschienen die typischen Krankheitssymptome. Durch intensive Düngung wurde das Durchbrechen der Latenzperiode gefördert. Hohe Bakterienkonzentrationen wurden besonders in den Stengelnodien, aber auch in den Blüten und Wurzeln gefunden.

Auch bei Latenz konnten die Bakterien systemisch in der Pflanze verbreitet sein und dann unerkannt durch Stecklinge übertragen werden.

3) Versuche zur Übertragung zeigten, dass die Bakterien auf den Blättern bis zu 2,5 Monate epiphytisch überleben konnten, bis sie die Pflanze systemisch besiedelten. 
Das Begießen der Topferde mit Bakteriensuspension führte zur Erkrankung mit hohen Bakterienkonzentrationen in den Wurzeln.

Auch im Sickerwasser aus infizierten Pflanzen wurden die Bakterien in Konzentrationen bis zu $10^{4} \mathrm{cfu} / \mathrm{ml}$ nachgewiesen.

Drei mit Pelargonien verwandte Pflanzenarten (Erodium cicutorium, Geranium dissectum, Geranium pusillum) waren anfällig für Xcp und zeigten 12 Tage nach Inokulation typische Krankheitssymptome und hohe Bakterienkonzentrationen ( $\left.>10^{8} \mathrm{cfu} / \mathrm{g}\right)$ im Stengel. Bei Geranium pusillum wurden die Bakterien auch im Samen nachgewiesen.

4) Für einen schnellen Nachweis der Bakterien im Routineverfahren durch den ELISA wurden 5 verschiedene Seren verglichen. Die höchste Nachweisempfindlichkeit zeigte ein polyklonales Antiserum vom IPO (Niederlande). Kreuzreaktionen mit anderen phytopathogenen oder saprophytischen Bakterien wurden nicht festgestellt. Noch bei einer Serum-Verdünnung von 1:1000 wurden 5 verschiedene $X c p$-Stämme herab bis zu $10^{3} \mathrm{cfu} / \mathrm{ml}$ sicher nachgewiesen, auch bei Mischung mit Pflanzenextrakt.

Auch in teilweise verholzten Pelargonienstengeln, die seit 4 Jahren latent mit Xcp infiziert waren, konnten die Bakterien nachgewiesen werden. Nach Inkubation des Pflanzenextraktes für $24 \mathrm{~h}$ in TC-Lösung (Zwischenvermehrung der gesuchten Bakterien) konnte noch eine ursprüngliche Konzentration von $10^{2} \mathrm{cfu} / \mathrm{ml}$ in der Pflanze nachgewiesen werden.

5) Durch Einsatz der Polymerase-Kettenreaktion (PCR) mit einem von KRÄMER (1998) entwickelten Primer-Paar wurde eine Nachweisgrenze im Pflanzenextrakt von $10^{3}-10^{4}$ cfu/g Frischgewicht erreicht.

Mit der BIO-PCR, d. h. nach 24-stündiger Zwischenvermehrung in TC-Lösung, konnte die Nachweisempfindlichkeit auf $1,2 \times 10^{3} \mathrm{cfu} / \mathrm{ml}$ ( = 50 cfu pro PCR-Ansatz) gesenkt werden, so dass die Bakterien noch in seit 4 Jahren latent befallenen, symptomlosen Pflanzen detektiert werden konnten.

Es wurde eine schwache Kreuzreaktion gegenüber $X$. c. pv. zinniae festgestellt. Auch die PCR könnte nach diesen Ergebnissen in Routinetests zum Nachweis von Xcp eingesetzt werden. Im Vergleich mit den beiden indirekten Nachweismethoden (ELISA und PCR) sollte jedoch der direkte mikrobiologische Nachweis mit einem semiselektiven Nährmedium nicht ausgeschlossen werden, da er schnell, sicher und kostengünstig ist. 


\section{KAPITEL VI}

\section{LITERATURVERZEICHNIS}

AL-SHINAWI, T. (1996): Untersuchungen zur Epidemiologie von Pseudomonas syringae pv. coriandricola, dem Erreger des bakteriellen Doldenbrandes an Koriander (Coriandrum sativum L.), und $\mathrm{zu}$ seiner Bekämpfung durch resistente Linien. Dissertation, Universität Göttingen.

ANONYM (1992): Certification scheme of pathogen-tested material of pelargonium. Bulletin OEPP/EPPO Bulletin 22: 285-296.

ANONYM (2002): Certification scheme for pelargonium. Bulletin OEPP/EPPO Bulletin $32,67-78$.

BACHTHALER, E. (1973): Die züchterische Entwicklung der Pelargonium-zonaleHybriden. Erwerbsgärtner 27: 356-359.

BACHTHALER, E. und KREBS , E. - K. (1987): Pelargonium zonale und Pelargonium inquinans- Auf der Suche nach Xanthomonas resistenten Wildtypen. Gartenbörse und Gartenwelt 87: 1863-1864.

BATUR, H. (1994): Ein neues Selektivmedium für Xanthomonas campestris pv. pelargonii, den Erreger der Stengelfäule und der Blattfleckenkrankheit von Pelargonien. Magisterarbeit, Universität Göttingen.

BATUR, H., MAVRIDIS, A. und RUDOLPH, K. (1993): Ein neues Selektivmedium für Xanthomonas campestris pv. pelargonii, den Erreger der Stengelfäule und der Blattfleckenkrankheit von Pelargonien. Mitteilung. Biolog. Bundesanst. Land- und Forstwirtsch: 357: 311-312.

BATUR-MICHAELIS, H., MAVRIDIS, A., RUDOLPH, K. und BRIELMAIERLIEBETANZ, U. (1998): Untersuchungen über das Verhalten von Xanthomonas campestris pv. pelargonii in latent befallenen Pelargonienpflanzen. Mitteilung. Biolog. Bundesanst. Land- und Forstwirtsch. 376: 311.

BENEDICT, A. A., AlvareZ, A. M., POLlARD, L. W. (1990): Pathovar-specific antigens of Xanthomonas campestris pv begoniae and Xanthomonas campestris pv. pelargonii. Appl. Environ. Microbiol. 56: 572-574.

BENITZ, and TATRO, (1988): Pediatric Drug Handbook, 2nd Edition, 1988, p. 548

BERESWILL, S., PAHL, A., ZELLER, W. and GEIDER, K. (1992): Sensitive and species-specific detection of Erwinia amylovora by polymerase chain reaction analysis. Appl. Environ. Microbiol. 58: 3522-3526. 
BERKELMANN, B. und WOHANKA, W. (1993): Xanthomonas campestris pv. pelargonii. Was leisten die Nachweismethoden? Deutscher Gartenbau 19: 12441247.

BERKELMANN. B., WOHANKA, W. and BREIDBACH, J. (1994): Investigations into the certain detection of Xanthomonas campestris pv. pelargonii in geranium cuttings. Med. Fac. Landbouww. Univ. Gent 59/3b: 1201-1207.

BERKELMANN. B., WOHANKA, W. und BREIDBACH, J. (1994): Bemerkungen zur Xanthomonas-Testung an Pelargonien-Stecklingen. Phytomedizin, Mitteil. Deutsch. Phytomed. Gesellschaft, 24/2, 23-24.

BLAKEMAN, J. P. (1993): Pathogens in the foliar environment. Plant Pathology, 42: 479473.

BOCHNER, B. (1989): "Breathprints“ at microbial level, ASM news, 55: 536-539.

BOSSHARD, E. (1978): Nachweis von Xanthomonas pelargonii in Geranienstecklingen. Gartenbau (Schweiz), 2: 43-45

BOSSHARD, E. und VOGELSANGER, J. (1979): Wirkung verschiedener Substratbehandlungen auf Xanthomonas pelargonii. Gartenbau 100: 143-145.

BRADBURY, J. F. (1986): Guide to Plant Pathogenic Bacteria. C. A. B. International, Farnham House, Farnham Royal, Slough SL2 3BN, Großbritannien, 157

BRIELMAIER-LIEBETANZ, U. und SADOWSKA-RYBAK, M. (1994): Vergleich von Antiseren zum Nachweis von Xanthomonas campestris pv. pelargonii im enzymelinked immunosorbent assay (ELISA). Nachrichtenbl. Deut. Pflanzenschutzd. 46: $37-40$.

BRÖTHER, H. (1979): Zur Rolle bakterieller Krankheitserreger an Pelargonien. Nachrichtenblatt für den Pflanzenschutz in der DDR. 33: 225-228.

BRÖTHER, H. (1981a): Die bakterielle Pelargonienwelke (Xanthomonas pelargonii) und Möglichkeiten ihrer Bekämpfung. Nachrichtenblatt für den Pflanzenschutz in der DDR. 35: 3-6.

BRÖTHER, H. (1981b): Untersuchungen über Nachwies, Pathogenese und Verbreitung von Xanthomoas campestris pv. pelargonii (BROWN) DYE an Pelargonien in der DDR. Dissertation, Humboldt-Universität Berlin.

BROWN, N. (1923): Bacterial leaf spot of Geranium in the Eastern United States. Agricultur. Res. 23: 361-371.

BUCHANAN, R. E. and GIBBONS, N. E. (1974): Bergey`s Manual of Determinative Bacteriology, $8{ }^{\text {th }}$ ed. Baltimore: Williams \& Wilkins Co. 
BUGBEE, W.M., and ANDERSON, N. A. (1963): Whitefly transmission of Xanthomonas pelargonii and histological examination of leafspots of Pelargonium hortorum. Phytopathology $53: 177-178$.

BURKI, T. (1974): Zur Wirkung einiger Desinfektionsmittel gegen Xanthomonas pelargonii (Brown) Starr et Burkholder. Schweiz. Landw. Forsch. (13): 519-529.

CAFATI, C. R. and SAETTLER, A.W. (1980): Effect of host on multiplication and distribution of bean common blight bacteria. Phytopathology 70: 675-679.

CASPER, R. (1977): Detection of potato leafroll virus in potato and in Physalis floridana by enzyme-linked immunosorbent assay (ELISA). Phytopathol. Z. 90: 364-368.

CASPER, R. und MAYER, K. (1981): Die Anwendung des ELISA-Verfahrens zum Nachweis pflanzenpathogener Viren. Nachrichtenblatt Deut. Pflanzenschutzd. 33: 49-54.

CERNUSKO, R. (1995): Entwicklung und Erprobung enzymatischer und immunologischer Nachweismethoden für Verticillium dahliae Kleb. im Raps (Brassica napus L.). Dissertation, Universität Göttingen.

CHENG, P. J., HEMMLÄ, I. and LÖVGREN, T. (1982): Development of solid-phase immunoassay using chemiluminescent IgG conjugates. J. Immuno. Met. 48: 159168.

CLAFLIN, L. E., VIDAVER, A. K. and SASSER, M. (1987): MXP, a semi-selective medium for Xanthomonas campestris pv. phaseoli. Phytopathology 77: 730-734.

CLARK, M. F. (1981): Immonosorbent assays in plant pathology. Ann. Rev. Phytopathol. 19: 83-106.

CLARK, M. F. and ADAMS, A. N. (1977): Characteristics of the microplate method of enzyme-linked immunosorbent assay for the detection of plant viruses. J. Gen. Virol. 34: 475-483.

CLARK, M. F., ADAMS, A. N. and BARBARA, D. J. (1976): The detection of plant viruses by enzyme-linked immunosorbent assay (ELISA). Acta Hort. 67: 43-49.

COOKE D. L., WAITES, W. M. and LEIFERT, C. (1992): Effects of Agrobacterium tumefaciens, Erwinia caratovora, Pseudomonas syringae and Xanthomonas campestris on plant tissue cultures of aster, cheiranthus, delphinium, iris and rosa; disease development in vivo as a result of latent infection in vitro. $\mathrm{Z}$. Pflanzenkankh. u. Pflanzensch. 99: 469-481.

CROSSE, J. E., (1959): Bacterial canker of stone fruit. VI: Investigation of a method for measuring the inoculum potential of cherry trees. Ann. Appl. Biology, 47, 306-317.

CROSSE, J. E., GOODMAN, R. N. und. SHAFFER, W. H. (1972): Leaf damage as a predisposing factor in the infection of apple shoots by Erwinia amylovora. Pytopathology 62: 176-182. 
DANIELS, M. J. (1992): Interaction of Xanthomonas with crucifers. Neth. J. Pl. Path. 2: 147-155.

DAUGHTREY, M. and MACKSEL, M. (1993): Nursey-cultivated Geranium spp. as a possible inoculum source for Xanthomonas campestris pv. pelargonii causing bacterial blight disease of a greenhouse pelargonium crop. Phytopathology 83 : 242.

DeBOER, S. H. (1990): Immunofluorescence for bacteria. In: HAMPTON, R., BALL, E., DeBOER, S. H. (Eds.), Serological Methods for Detection and Identification of Viral and Bacterial Plant Pathogens. APS Press, St. Paul, USA, 295-298.

DE BRUIJN, F. J. (1987):Transposon Tn5 mutagenesis to map genes. Methods Enzymol. 154: $175-196$

DEMEKE, T. and ADAMS, R. P. (1992): The effects of plant polysaccharides and buffer additives on PCR. Bio Techniques, 12: 332-333.

DENG, S. and HIRUKI, C. (1991): Genetic relatedness between two nonculturable mycoplasmalike organisms revealed by nucleic acid hybridisation and polymerase chain reaction. Phytopathology 81: 1475-1479.

DIGAT, B. (1977): Aspects nouveaux en matiere de lutte contre les bacterioses du Pelargonium. Rev. Horticole 174 : 41-42.

DINESEN, G. (1981): Production of plants free of pathogenic bacteria. Proceedings of the $5^{\text {th }}$ International Conference of Plant Pathogenic Bacteria. Cali. 518-522.

DOUGHERTY, D. E.,. POWELL, C. C and LARSEN, P. O. (1974): Epidemiology and control of bacterial leaf spot and stem rot of Pelargonium hortorum. Phytopathology 64: 1081-1083.

DÜMMEN, C. (1994): Praxisgerechte Optimierung des ELISA und des AusstrichVerfahrens zum sicheren Nachweis von Xanthomonas campestris pv. pelargonii in Pelargonien-Hybriden. Diplomarbeit, Fachhochschule Wiesbaden.

DÜMMEN (1991/1992): Produktinformation der Firma Dümmen Jungpflanzenkulturen, Rheinberg

DUNBAR, K. B. and STEPHENS, C. T. (1989): An in vitro screen for detecting resistance in Pelargonium somaclones to bacterial blight of Geranium. Plant Disease 73: 910912

DUVEILLER, E. (1989): Research on Xanthomonas translucens of wheat and triticale at CIMMYT (Centro Internacional de Mejoramiento de Maiz y Trigo). Bulletin OEPP/EPPO 19: 97-103. 
DYE, D. W. (1978): Genus IX Xanthomonas DOWSON 1939. In YOUNG, J. M., DYE, D. W.; BRADBURY, J. F., PANAGOPOULOS, C. G., and ROBBS, C. F. (1978): A proposed nomenclature and classification for plant pathogenic bacteria. N. Z. J. Agr. Res. 21: 153-177.

ELPHINSTONE, J. G., HENNESSY, J., WILSON, J. K. and STEAD, D. E. (1996): Sensitivity of different methods for the detection of Ralstonia solanacearum in potato tuber extracts. BULL. OEPP/EPPO BULL. 26: 663-678.

ENGVALL, E. and PERLMANN, P. (1971): Enzyme-linked immunosorbent assay (ELISA). Quantitative assay of immunoglobulin G. Immunochemistry 8: 871-874.

ENGVALL, E. and PERLMANN, P. (1972): Enzyme-linked immunosorbent assay (ELISA). III. Quantitation of species antibodies by enzyme-labelled antiimmunoglobulin in antigen- coated tubes. J. Immunology 109: 129-135.

ERCOLANI, G. L., HAGADORN, D. J., KELMAN, A., and RAND, R. E. (1974): Epiphytic survival of Pseudomonas syringae on hairy vetch in relation to epidemiology of bacterial brown spot of bean in Wisconsin. Phytopathology 64: 1330-1339.

FESSEHAIE, A. (1997): Biochemical/Physiological characterization and Detection Methodes of Xanthomonas campestris pv. manihotis (Berthet-Bondar) DYE 1978, the causel organism of Cassava Bacterial Blight. Dissertation, Universität Göttingen.

FISCHER-TÖHL, I. (1992): Gesunderhaltung und Selektion von Pelargonien. Gartenbörse und Gartenwelt 51: 2455-2459.

FLAHERTY, J. E., HARBAUG, B. K., JONES, J. B., SOMODI, G. C. and JACKSON, L. E. (2001): H-mutant bacteriophages as a potential biocontrol of bacterial blight of geranium. Horticience 36:98-100.

FRANKE, H. (1994): (Persönliche Mitteilung) ELSNER-PAC, Dresden

FRIEMEL, H. (1991): Immunologische Arbeitsmethoden. Gustav Fischer Verlag, Jena

GANNINGER-HAUCK, D. (1993): German Floriculture: Struggling for position against strong neighbours. Flora Culture International. 12: 12-14.

GANSLMEIER, H. (1987): Beet- und Balkonpflanzen. Verlag Eugen Ulmer, Stuttgart.

GEIDER, K. (1990): Der Feuerbrand des Kernobstes: Molekulare Biologie des Erregers Erwinia amylovora. Forum Mikrobiologie, Heft 5.

GIBONI, F. (1985): Krankheiten und Schädlinge an Pelargonien. Gartenbörse und Gartenwelt 85: 74-83. 
GIBONI, F. (1993): Krankheiten und Schädlinge an Pelargonien II. Gartenbörse und Gartenwelt 93 (9): 445-447.

GLEASON, M. L., BRAUN, E. J., CARLTON, W. M. and PETERSON, R. H. (1991): Survival and dissemination of Clavibacter michiganensis subsp. michiganensis in tomatoes. Phytopathology 81: 1519-1523.

GLICK, D. L. COFFEY, C. M. and SULZINSKI, M. A. (2002): Simultaneous PCR detection of the two major bacterial pathogens of Geranium. J. Phytopathology 150: $54-59$.

GOODMAN, R. N. and WHITE, J. A (1981): Xylem parenchyma plasmolysis and vessel wall disorientation are early signs of pathogenesis caused by Erwinia amylovora. Phytopathology 71: 844-852.

GOTTSCHALK, S. (1998): Untersuchungen zur biologischen Bekämpfung des Erregers der Kraut- und Knollenfäule der Kartoffel (Phytophthora infestans (Mont.) de Bary): Einsatz mikrobieller Antagonisten und ihrer Sekundärmetabolite. Dissertation, Universität Göttingen.

GRIESBACH, E., TEGTMEIER, H. U. und SCHMATZ, R. (1985): Serologischer Nachweis zur Diagnose von Xanthomonas campestris pv. pelargonii (Pammel) Dowson und zur Selektion befallener Pelargonienpflanzen. Nachrichtenbl. Pflanzensch. in der DDR 39: 10-13.

GRIESBACH, E., und TYRACH, A. (1999): Evalution of resitance to Xanthomonas hortorum pv. pelargonii at Pelargonium. Beiträge zur Züchtungsforsch. BAZ, 5. Jahrgang, 1: 68-69.

GRIESBACH, E., und TYRACH, A. und OLBRICHT, K. (1999): Resistenz bei Pelargonium-Arten und-Hybriden gegen Xanthomonas hortorum pv. pelargonii. Vort. Pflanzenzüchtg. 46: 285-292.

HAMACHER, J. und KURZE, S. (1996): Licht- und elektronmikroskopische Untersuchungen zur Ausbreitung von Xanthomoas campestris pv. pelargonii (Xcp) in zonalen Pelargonienhybriden. Mitteilung. Biolog. Bundesanst. Land- und Forstwirtsch. 321: 557.

HAMPTON, R., BALL, E. and DE BOER, S. (1990): Serological Methods for Detection and Identification of Viral and Bacterial Plant Pathogens. APS-Press, St. Paul, Minnesota, USA

HARRISON, J. G., LOWE, R. and DUNCAN, J. M. (1991): Use of ELISA for assessing major gene resistance of potato leaves to Phytophthora infestans. Plant Pathology 44: 431-435.

HARTUNG, J. S., DANIEL, J. F. and PRUVOST, O. P (1993): Detection of Xanthomonas campestris pv. citri by the polymerase chain reaction. Appl. Environ. Microbiol. 59: $1143-1148$. 
HATTINGH, M. J., ROOS, M. M. and MANSVELT, E. L. (1989): Infection and systemic invasion of deciduous fruit trees by Pseudomonas syringae in South Africa. Plant Disease 73: 784-789.

HEIMANN, M. (1973): Möglichkeiten und Grenzen der Bekämpfung von Xanthomonas pelargonii Brown. Erwerbsgärtner 27: 343-346.

HENSELER, K. (1970: Die Bekämpfung der bakteriellen Stammfäule bei Pelargonien (Xanthomonas pelargonii) ist zur Zeit nur durch geeignete Kulturmaßnahmen möglich. Jahresbericht 1970 der Versuchsanstalten und Beispielsbetriebe für Gartenbau der Landwirtschaftskammer Rheinland, 253-254.

HELLMERS, E. (1952): Bacterial leaf spot of pelargonium (Xanthomonas pelargonii) ((BROWN) STARR \& BURKHOLDER) in Denmark. Trans. Dan. Acad. Tech. Sci. No. 4:1-40.

HEPPNER, C. (1995): Nachweis von Verticillium dahliae Kleb. im Boden mit Plattengußverfahren und ELISA (enzyme-linked immunosorbent assay) sowie Untersuchungen zur Auswirkung des Inokulums auf den Befall von Winterraps (Brassica napus ssp. oleifera Metzg.). Dissertation, Universität Göttingen.

HIRANO, S. S and UPPER, C. D. (1993): Dynamics, spread, and persistence of a single genotype of Pseudomonas syringae relative to those of its conspecifics on populations of snap bean leaflets. Appl. Environm. Microbiology 59: 1082-1091.

HIRANO, S. S and UPPER, C. D. (1983): Ecology and epidemiology of foliar bacterial plant pathogens. Ann. Rev. Phytopatholgy 21: 243-269.

IDCZAK, E. and BRIELMAIER-LIEBETANZ, U. (1999): Detection of Xanthomonas campestris pv. pelargonii (actual situation). Beiträge zur Züchtung Forschung 5 (1): 10-13.

JIAO, J., GOODWIN, P., GRODZINSKI, B. (1999): Inhibition of photosynthesis and export in geranium grown at two $\mathrm{CO}_{2}$ levels and infected with Xanthomonas campestris pv. pelargonii. Plant Cell and Environment 22 : 15-25.

JOHN, M. E. (1992): An efficient method for isolation of RNA and DNA from plants containing polyphenolics. Nucleic Acids Res. 20: 2381.

KAHAN, F. M., KAHAN, J. S., CASSIDY, P. J. and KROPP, H. (1974): The mechanism of action of fosfomycin (fosfonomycin). Ann. N. Y. Acad. Sci. 235: 364-368.

KARIYONE, K., HARADA, H., KURITA, M. and TAKANO, T. (1970): Cefazolin, a new semisynthetic cephalosporin antibiotic. Synthesis and chemical properties of Cefazolin. J. Antibiot. 23: 131-136.

KASTEN, F. H. (1981): Methods for fluorescence micoscropy. In: WILLIAMS \& WILKINS (Eds), Straining procedures used by the Biological Stain Commission, Baltimore, USA, 39-43. 
KENNEDY, B.W., PFLEGER, F. L. and DENNY, R. (1987): Bacterial leaf and stem rot of geranium in Minnesota. Plant Disease 71: 821-823.

KHATRI-CHHETRI, G. B. (1999): Detection and characterization of Xanthomonas campestris pv. vignicola strains, incitant of cowpea bacterial blight and pustule, and studies on genotype/strain-interactions. Dissertation, Universität Göttingen.

KIM, H. K. (1982): Epidemiological, genetical and physiological studies of the bacterial leaf streak pathogen, Xanthomonas campestris pv. translucens (J.J.R. Dowson). $\mathrm{PhD}$. Thesis. Montana State University, Bozeman, 94 pp.

KING, E. O., WARD, M. K. and RANAY, D. E. (1954): Two simple media for the detection of pyocyanin and fluorescein. J. Lab. Clin. Med., 44: 301-307.

KIVILAAN, A. and SCHEFFER, R. P. (1958): Factors affecting development of bacterial stem rot of Pelargonium. Phytopathology 48: 185-191.

KLEINHEMPEL, H., NAUMANN, K. und SPAAR, D. (1989): Bakterielle Erkrankungen der Kulturpflanzen. Springer Verlag, Berlin.

KLOPMEYER, M. J. (1992): Zero tolerance for Xanthomonas: Myth. or fact? Pages 139141 in: Proc. Int. Geranium, 3rd R. Craig, ed. Ball Publishing, Batavia, IL,

KNAPOVA, G. (1995): Entwicklung und Prüfung eines ELISA zum Nachweis von Phytophthora infestans (Mont.) de Bary. Dissertation, Universität Göttingen.

KNAUSS, J. F. and TAMMEN, J. (1967): Resistance of Pelargonium to Xanthomonas pelargonii. Phytopathology 57: 1178-1181.

KOOPMANN, B. (1999): Script zum Praktikum Molekulargenetische Methoden in der Phytopathologie. 9-10.

KOUCHEKI, H. K. (1973b): The role of seed in transmission of a disease of Pelargonium hortorum. Plant Disease Reporter 57: 909-911.

KRÄMER, I. (1994): Charakterisierung und Differenzierung von Xanthomonas campestris-Pathovaren mittels PCR. Mitteilung. Biolog. Bundesanst. 301: 158.

KRÄMER, I., SCHUBERT, J. und GRIESBACH, E. (1998): Nutzung eines RAPDMarkers zum Nachweis von Xanthomonas campestris pv. pelargonii. Mitteilung. Biolog. Bundesanst. 376: 258.

KREBS, E. K. (1992): Xanthomonas - wichtigster Schaderreger an Pelargonium. Gartenbörse und Gartenwelt 37: 1802-1805.

KREBS, E.K., SCHENK, M., BACHTHALER, E. (1993): Stickstoffangebot und Verlauf der bakteriellen Welke bei Pelargonien. Gartenbau-Magazin 2: 59-60. 
KUAN, T. L., MINSAVAGE, G. V. and GABRIELSON, R. L (1985): Detection of Xanthomonas campestris pv. carotae in carrot seed. Plant Disease 69: 760-785.

KURZE, S. (1997): Histologische und immunhistologische Untersuchungen zur Ausbreitung von Xanthomonas campestris pv. pelargonii in künstlich inokulierten Pelargonienstecklingen. Diplomarbeit, Universität Bonn.

LAUGHNER, L. (1993): History. Pages 363-371In: Geraniums IV. J. W. White, ed. Ball Publishing, Geneva, IL.

LANCINI, G. and PARANTI, F. (1982): Antibiotics: An Integrated View. Springer Verlag, New York, Heidelberg, Berlin.

LEBEN, C., DAFT, G. C. and SCHMITTENNER, A. F. (1968): Bacterial blight of soybean population levels of Pseudomonas syringae in relation to symptom development. Phytopathology 58: 1143-1181.

LEBEN, C., SCHROTH, M. N. and HIDERBRAND, D. C. (1970): Colonization and movement of Pseudomonas syringae on healthy bean seedlings. Phytopathology 60: $677-680$.

LEBEN, C. (1973): Survival of plant pathogenic bacteria. Abstr. No 0326. Second Int. Congr. Plant Path., Minneapolis Minn., Sept. 5-12.

LELLIOTT, R. A. and STEAD, D. E. (1987): Methods for the Diagnosis of Bacterial Diseases of Plants. Blackwell Scientific Publications, Oxford.

LEQUET, F. (1888): La maladie des Pelargonium zonale et inquinans hybrides. Rev. Hortic. 60: 166-168.

LEWIS, I. M. (1914): A bacterial disease of Erodium und Pelargonium. Phytopathology 4: 221-233.

LEYNS, F., DE CLEENE, M., VAN DE WIELE, A. and DE LEY, J. (1988): Preliminary investigations about the mode of transmission and spread of Xanthomonas campestris pv. graminis on forage grasses. J. Phytopathology 122: 76-88.

LIN, C. P., CHEN, T. A., WELLS, J. M. and VAN DER ZWET, T. (1987): Identification and detection of Erwinia amylovora with monoclonal antibodies. Phytopathology 77: $376-380$.

LINDEMANN, J., ARNY, D. C and UPPER, C. D. (1984): Use of an apparent infection threshold population of Pseudomonas syringae to predict incidence and severity of brown spot of bean. Phytopathology 74: 1334-1339.

LINDOW, S. E., KNUDSEN, G. R., DEIDLER, R. J., WALTER, M. W., LAMBOU, V. W., AMY, P. S., SCHMEDDING, D., PRINCE V. and HERN, S. (1988): Aerial dispersal and epiphytic survival of Pseudomonas syringae during a pretest for the 
release of genetically engineered strains into the environment. Appl. Environm. Microbiology 54: 1557-1563.

MANULIS, S., VALINSKY, L., LICHTER, A. and GABRIEL, D. W. (1994): Sensitive and specific detection of Xanthomonas campestris pv. pelargonii with DNA primers and probes identified by random amplified polymorphic DNA analysis. Appl. Environm. Microbiol. 60: 4094-4099.

MANULIS, S., CHALUPOWICZ, L., DROOR, O. and KLEITMAN, F. (2002): Molecular diagnostic procedures for production of pathogen-free propagation material. Pest Management Science 58 : 1226-1131.

MAVRIDIS, A.: (Persönliche Mitteilung 1989)

McCARTER, S. M., JONES, J. B., GITAITIS, R. D. and SMITLEY, D. R. (1983): Survival of Pseudomonas syringae pv. tomato in association with tomato seed, soil, host tissue and epiphytic weed hosts in Georgia. Phytopathology 73: 1393-1398.

McGUIRE, R. G., JONES, J. B. and SASSER, M. (1986): Tween media for semiselective isolation of Xanthomonas campestris pv. vesicatoria from soil and plant material. Plant Disease 70: 887-891.

MILLER, J. W. and VIRGONA, R. J. (1978): Bacterial blight of Geraniums. Plant Pathology Circular, Florida Dept. Agric. Cons. Services 92, 1-2.

MILUS, E. A. and MIRLOHI, A. F. (1993): A test tube assay for estimating populations of Xanthomonas campestris pv. translucens on individual wheat leaves. Phytopathology 83: 134-139.

MOORMAN, G. W. (1999): www.cas.psu.edu/docs/CASDEPT/PLANT/ext/bactbl-g.html

MOHAN, S. K. and SCHAAD, N. W. (1987): An improved agar plating assay for detecting Pseudomonas syringae pv. syringae and Pseudomonas syringae pv. phaseolicola in contaminated bean seed. Phytopathology 77: 1390-1395.

MÖLLER, F. (1994): Untersuchungen zum Vorkommen bakterieller Endophyten in Pelargonium-Zonale-Hybriden "Alex“. Diplomarbeit, Fachhochschule Wiesbaden.

MUNNECKE, D. E., (1954): Bacterial stem rot and leaf spot of Pelargonium. Phytopathology 44: 627-632.

NABIZADEH-ARDEKANI, F., KOOPMANN, B. and RUDOLPH, K. (1997): Detection of bacterial diseases of tomatoes by the polymerase chain reaction (PCR) and serology. In: DEHNE, H.-W., ADAM, G., DIEKMANN, M., FRAHM, J., MAULER-MACHNIK, A. and van HALTEREN, P. (eds.): Diagnosis and Identification of Plant Pathogens, Proceedings of the $4^{\text {th }}$ International Symposium of the European Foundation for Plant Pathology, Sep. 9-12, 1996, Bonn, Germany, pp. 453-455. 
NABIZADEH-ARDEKANI, F. (1999): Nachweis bakterieller Krankheiten der Tomate durch die Polymerase-Kettenreaktion oder serologische Methoden und Bestimmung des Rassenspektrums von Pseudomonas syringae pv. tomato in der Türkei. Dissertation, Universität Göttingen.

NAMETH, S. T., DAUGHTREY, M. L., MOORMAN, G.W and SULZINSKI, M. A. (1999): Bacterial blight of geranium: a history of diagnostic challenges. Plant Disease 83: 205-212.

NEMEC, S. (1973): Phenolics in the strawberry root. Ann. Bot. 37: 935-941.

NELSON, P. E. and WAINWRIGHT, S. H. (1973): The anatomy of resistant and susceptible Pelargonium species infected with the bacterial blight organism. Bulletin of the Pennsylvania Flower Growers 289: 7-9.

NEUHAUS, C. und GIERSIEPEN, R. (1992): Untersuchungen zum Nachweis von Xanthomonas campestris pv. pelargonii mit Hilfe elekronenmikroskopischer Verfahren. Mitteilung. Biolog. Bundesanst. Land- und Forstwirtsch. 283: 323.

NIEPOLD, F. (1994): Anwendung der Polymerase-Kettenreaktion (PCR) zum Nachweis von Erwinia caratovora ssp. atroseptica, dem Erreger der Schwarzbeinigkeit und Naßfäule bei Kartoffeln. Nachrichtenbl. Deut. Pflanzenschutzd. 46: 243-246.

NORMEN, D. and ALVAREZ, A. (1989): A rapid method for presumptive identification of Xanthomonas campestris pv. dieffenbachiae and other xanthomonads. Plant Disease 73: 654-658.

O`BRIEN, R. D. and LINDOW, S. E. (1989): Effect of plant species and environment conditions on epiphytic population sizes of Pseudomonas syringae and other bacteria. Phytopathology 79: 919-927.

OLBRICHT, K. and GRIESBACH, E. (2002): First results of resistance evaluation of Pelargonium to Xanthomonas hortorum pv. pelargonii. Beitr. Züchtungsforschung, Bundesanst. Züchtungsforschung Kulturpflanzen 8: 26-28

OTTEN, H. (1975): Antibiotika-Fibel. 4. Aufl. Thieme Verlag, Stuttgart.

PALLERONI, N. J. and DOUDOROFF, M. (1972): Some properties and taxonomic subdivision of the genus Pseudomonas. Ann. Rev. Phytopathology 10: 73-100.

PAGEL, W. (1993): Xanthomonas campestris pv pelargonii: Cause of bacterial leaf spot and stem rot on Pelargonium spp. In: SWINGS, J. G. and CIVEROLO, E. L. (Eds.). Xanthomonas, Chapman and Hall, London, pp. 79-83.

PHYTOTEST (1993): Neue Diagnose-Methode bei der Bakterienwelke (Xanthomonas campestris pv pelargonii). Deutscher Gartenbau 4: 194.

PRIESTLEY, R. A. and DEWEY, F. M. (1993): Development of a monoclonal antibody immunoassay for the eyespot pathogen Pseudocercosporella herpotrichoides. Plant Pathology 42: 403-412. 
RABENSTEIN, F., ZIELKE, R. und NAUMANN, K. (1994): Nachweis von Xanthomonas campestris pv. pelargonii mit polyklonalen Antiseren und monoklonalen Antikörpern. Vorträge für Pflanzenzüchtung (BAZ) 28, 327-329.

RABENSTEIN, F., ZIELKE, R. und PROLL, E. (1994): Entwicklung immundiagnostischer Methoden unter Verwendung von polyklonalen Antiseren und monoklonalen Antikörpern für den Nachweis von Xanthomonas campestris pv. pelargonii und begoniae in Zierpflanzen. Jahresberichte der BAZ.

RANDHAWA, P. and SCHAAD, N. W. (1984): Selective isolaton of Xanthomonas campestris pv. campestris from crucifer seeds. Phytopathology 74: 268-272.

REUTHER, G. (1975): Untersuchungen zur Vermehrung von Pelargonienvarietäten durch Gewebekultur. Gartenbauwissenschaft 4: 181-187.

REUTHER, G. (1983): Propagation of disease-free Pelargonium cultivars by tissue culture. Acta Horticulturae 131: 311-315.

REUTHER; G. (1988): Problems of transmission and identification of bacteria in tissue culture propagated geraniums. Acta Horticulturae. 225: 139-152.

REUTHER, G. und SONNEBORN, H. H. (1981): Neue Technologien eröffnen Möglichkeiten zur Früherkennung pflanzlicher Virosen. Zierpflanzenbau 11: 478479.

RHODES, M. E., (1959): The characterization of Pseudomonas fluorescens. J. gen. Microbiology 21: 221-263.

ROBERTSON, N. L., FRENCH, R. and GRAY, S. M. (1991): Use of group specific primers and the polymerase chain reaction for the detection and identification of luteoviruses. J. Gen. Virol. 72: 1473-1477.

ROTT, P., ABEL, M., SOUPA, D., FELDMANN, P. and LETOURMY, P. (1994): Population dynamics of Xanthomonas albilineans in sugercane plants as determined with an antibiotic resistant mutant. Plant Disease 78: 241-247.

ROY, M. A. and SASSER, M. (1990): Selective Media: Principles of design and use. In: KLEMENT, Z., RUDOLPH, K. and SANDS, D. C. edts.: Methods in Phytobacteriology. Akademiai Kiado, Budapest, pp. 61-65.

RUDOLPH, K. (1993): Infection of the plant by Xanthomonas. In: SWINGS, J. G. and CIVEROLO, E. L. (Eds.). Xanthomonas. Chapman and Hall, London, pp. 193-264.

RUDOLPH, K. (1995): "Pseudomonas syringae pathovars" In: "Pathogenesis and Host Specificity in Plant Disease." (Singh, U. S.; Singh, R. P.; Kohmoto, K., edts.) Prokaryotes Vol. I, pp. 47-138. 
RUISSEN, M. A., VAN DER VOSSEN, R. T .M. and KOCKS, C. G. (1993): Growth of Xanthomonas campestris pv. campestris populations at constant and variable temperatures. Neth. J. Pl. Path. 99: 173-179.

RUSSELL, P. E., 1975: Variation in the virluence of some streptomycin resistant mutants of Pseudomonas phaseolicola. J. Appl. Bacteriology 39: 175-180.

SADOWSKA-RYBAK, M. (1991): Die Entwicklung einer Schnelldiagnose des Feuerbranderregers (Erwinia amylovora (Burill) Winslow et al.) mit Hilfe des ELISA (enzyme-linked immunosorbent assay). Dissertation, Universität Hamburg.

SAIK, P. K., FALOONA, F., MULlis, K. B., HORN, G. T., EHRLICH, H. A. and ARNHEIM, N. (1985): Enzymatic amplification of $\beta$-globin genomic sequences and restriction site analysis for diagnosis of sickle cell anemia. Science 230: 13501354.

SAUTHOFF, W. (1974): Untersuchungen über die durch Xanthomonas pelargonii hervorgerufene Welkekrankheit der Pelargonien. Jahresbericht der Biol. Bundesanstalt für Land- und Forstwirtschaft in Berlin und Braunschwaig, 131-132.

SAUTHOFF, W. (1975): Untersuchungen über die durch Xanthomonas pelargonii hervorgerufene Welkekrankheit der Pelargonien. Jahresbericht der Biol. Bundesanstalt für Land- und Forstwirtschaft in Berlin und Braunschwaig, 115-116.

SAUTHOFF, W.(1978): Einfluß der Kulturbedingungen auf den Befall von Pelargonien durch Xanthomonas pelargonii. Jahresbericht der Biol. Bundesanstalt für Landund Forstwirtschaft in Berlin und Braunschwaig, 48.

SAUTHOFF, W. (1980): Einfluß der Kulturbedingungen auf den Befall von Pelargonien durch Xanthomonas pelargonii. Jahresbericht der Biologischen Bundesanstalt für Land- und Forstwirtschaft. 41.

SCHAAD, N. W. (1979): Serological identification of plant pathogenic bacteria. Annu. Rev. Phytopathology, 17: 123-147.

SCHAAD, N. W. and FORSTER, R. L. (1985): A semiselective agar medium for isolating Xanthomonas campestris pv. translucens from wheat seeds. Phytopathology, 75: 260-263.

SCHAAD, N. W. (1990): Serology: Selection and preparation of antigens (Immunogens). In: KLEMENT, Z., RUDOLPH, K. and SANDS, D. C. edts.: Methods in Phytobacteriology. Akademiai Kiado, Budapest, pp. 155-164.

SCHAAD, N. W., CHEONG, S. S., TAMAK, S., HATZILOUKAS, E. and PANOPOULOS, N. J. (1995): A combined biological and enzymatic amplification (BIO-PCR) technique to detect Pseudomonas syringae pv. phaseolicola in bean seed extracts. Phytopathology 85: 243-248. 
SCHAAD, W. N., VIDAVER, A. K., LACY, G. H., RUDOLPH, K. and JONES, J. B.: (2000) Evaluation of proposed amended names of several pseudomonads and xanthomonads and recommendations. Phytopathology 90: 208-213.

SCHAFFER, W. H. and GOODMAN, R. N. (1985): Appearance of streptomycin-resisitant Erwinia amylovora in Missouri apple orchards. Phytopathology 75: 1281.

STEPHENS, C. T. and TUINIER, J. (1989): Disease symptomatology and variation in susceptibility of seed-propagated hybrid Geranium varieties to Xanthomonas campestris pv. pelargonii. Plant Disease 73: 559-563.

STONE, G. E. and SMITH, R. E. (1898): A disease of the cultivated geranium. Mass. Agric. Exp. Stn. Annu. Rep. Bot. 10: 67.

STONE, G. E. and MONAHAN, N. F. (1907): Bacteriosis of geraniums. Mass. Agric. Exp. Stn. Annu. Rep. Bot. 19: 164.

SULZINSKI, M. A., MOORMAN, G.W., SCHLAGNHAUFER, B. and ROMAINE, C. P. (1995): Fingerprinting of Xanthomonas campestris pv. pelargonii and related pathovars using random-primed PCR. J. Phytopathology 143: 429-433.

SULZINSKI, M. A., MOORMAN, G.W., SCHLAGNHAUFER, B. and ROMAINE, C. P. (1996): Characteristics of a PCR-based assay for in planta detection of Xanthomonas campestris pv. pelargonii. J. Phytopathology 144: 393-398.

SULZINSKI, M. A., MOORMAN, G.W., SCHLAGNHAUFER, B. and ROMAINE, C. P. (1997): A simple DNA exraction method for PCR-based detection of Xanthomonas campestris pv. pelargonii in geraniums. J. Phytopathology 145: 213-215.

SULZINSKI, M. A., SCHLAGNHAUFER, B., MOORMAN, G.W. and ROMAINE, C. P. (1998): PCR-Based detection of artificial latent infections of geranium by Xanthomonas campestris pv. pelargonii. J. Phytopathology 146: 111-114.

SULZINSKI, M. A., (2001):Differentiation of Xanthomonas campestris pv. pelargonii and Xanthomonas campestris pv. hederae by polymerase chain reaction. J. Phytopathology 149: 45-49.

SUNDRAM, S., PLASENCIA, J. and BANTTARI, E. E. (1991): Enzyme-linked immunosorbent assay for detection of Verticillium ssp. using antisera produced to Verticillium dahliae from potato. Phytopathology 81: 1485-1489.

SWINGS, J. G. and CIVEROLO, E. L. (1993): Xanthomonas. Chapman and Hall, London,

TAMMEN, J. (1960): Disease-free geraniums from cultured cuttings. Pa. Flower Grow. Bull. 117: 1, 6-9.

TAYLOR, R. J., VENETTE, R. J. and LAMEY, H. A. (1996): Leaf spot and stem rot (bacterial blight) of Geranium (Pelargonium spp.). http://www.ext.nodak.edu/extpubs/plantsci/landscap/pp 739 w.htm. 
TSAI, Y. L. and OLSON, B. H. (1992): Rapid method for separation of bacterial DNA from humic substances in sediments for polymerase chain reaction. Appl. Environ. Microbiol. 58: 2292-2295.

TUINIER, J. E. and STEPHENS, C. T. (1989): Use of serology to detect Xanthomonas campestris pv. pelargonii in aqueous extracts of Geranium plants. Plant Disease 73: 875-878.

UNGER, J. (1989): Entwicklung und Erprobung eines ELISA (enzyme-linked immunosorbent assay) zum Nachweis von Fusarium culmorum ( W.G.Sm.) Sacc. und Pseudocercosporella herpotrichoides (Fron.) Deigh. im Weizen. Dissertation, Universität Göttingen.

VAUTERIN, L., HOSTE, B., KERSTERS, and SWINGS, J. (1995): Reclassification of Xanthomonas. Int. J. Syst. Bacteriol. 45: 472-489.

VAN der WOLF, J. M., VAN BECKHOVEN, J. R. M. C., MESSCHENDORP, J. W. J. and HOOFTMAN, R. (1999): Detection of Xanthomonas campestris pv. pelargonii by immunofluorescence colony-staining and PCR. In: Plant Pathogenic Bacteria (Ed. By A Mahadevan), pp. 149-154. University of Madras, Madras (IN).

VAN VUURDE, J. W. L. and ROOYEN, N. J. M. (1990): Comparison of immunofluorescence colony-staining in media, selective isolation on pectate medium, ELISA and immunofluorescence cell staining for detection of Erwinia carotovora subsp. atroseptica und E. chrysanthemi in cattle manure slurry. Neth. J. Plant Pathol. 96:75-89.

VON KIETZELL, J. M. (1995): Untersuchungen zur Epidemiologie und Spezifität von Pseudomonas syringae pv. atrofaciens ((McCulloch), Dye, Young, Wilkie), dem Erreger der basalen Spelzenfäule des Getreides. Dissertation, Universität Göttingen.

WAINWRIGHT, S. H. and NELSON, P. E. (1972): Histopathhology of Pelargonium species infected with Xanthomonas pelargonii. Phytopathology 62: 1337-1347.

WALDOW, F. (1997): Entwicklung und Erprobung immunologischer Methoden zum Nachweis des Kohlhernieerregers Plasmodiophora brassicae (Woron.) für Phytohygieneprüfungen von Komposten. Dissertation, Universität Göttingen.

WELLER, D. M. and SAETTLER, A. W. (1978): Rifampicin-resistant Xanthomonas phaseoli var. fuscans and Xanthomonas phaseoli: Tools for field study of bean blight bacteria. Phytopathology 68: 778-781.

WESTERHOF, J. and van RUITEN, J. E. M. (1992): International certification: Necessity of standardizing propagation schemes and testing procedures. Pages 125-131 In: Proc. In: Geranium Conf., 1992, 3rd. R. Craig, ed. Ball Publishing, Batavia, Illinois, USA. 
WHITE, J. W. (1993): Geraniums; The Growers Manual. Ball Publishing, Geneva, Illinois/USA.

WÖLK, M und SARKAR, S. (1994): Überleben einer Xanthomonas campestris pv. pelargonii-Mutante in einjähriger Komposterde. Anzeiger für Schädlingskunde Pflanzenschutz Umweltschutz, 67. Jahrgang (4): 69-71.

WOHANKA, W. (1994): Some remarks on detection methods for Xanthomonas. Proc. $3^{\text {rd }}$ Int. Geranium Conf., Odense-Denmark, 149-154.

WOODRUFF, F. M., KAHAN, F. M., WALLICK, H., MILLER, A. K. and STAPLEY, E. O. (1975): Fosfomycin, a cell-wall-active antibiotic not inactivated by episome mediated enzymes. In: MITSUHASHI, S and HASHIMOOTO, J (eds.): Microbiol Drug Resistance. Baltimore, University Park Press, 539-559.

YANG, X., HADIDI, A. and GARNSEY, S. M. (1992): Enzymatic cDNA amplification of citrus exocortis and cachexia viroids from infected citrus hosts. Phytopathology 82: 279-285.

YOUNG, J. M, BULL, C. T., De BOER, S. H., FIRRAO, G,. GARDAN, L., SADDLER, G. E., STEAD, D.E., TAKIKAWA, Y. (2001): Classification, nomenclature, and of plant pathogenic bacteria- a clarification. Phytopathology 91: 617-620.

ZARAGOZA, B. A. and MEW, T. W. (1979): Relationship of root injury to the 'Kresek' phase of bacterial blight of rice. Plant Disease Reporter 63: 1007-11.

ZIMMER, K., ESCHER, F., GUGENHAN, E. und KNEIPP, O. (1991): Hauptkulturen im Zierpflanzenbau. 259-285; Eugen Ulmer, Stuttgart

ZIMMERMANN, C., MOLTMANN, E. und BUCHENAUER, H. (2001): Nachweis von Xanthomonas fragariae, Erreger der Eckigen Blattfleckenkrankheit an Erdbeere, mittels PCR. Phytomedizin, Mitteil. der Deutsch. Phytomed. Gesellschaft 31 (1): 33-34. 


\section{Danksagung}

Mein besonderer Dank gilt Herrn Dr. K. Rudolph, unter dessen wissenschaftlicher Anleitung diese Arbeit angefertigt wurde, der mich durch seine Anregungen und ständige Diskussionsbereitschaft immer unterstützte und der mir wissenschafttlichen Freiraum zum selbständigen Arbeiten ließ. Nicht zuletzt danke ich ihm für die zeitraubende kritische Durchsicht des Manuskriptes dieser Arbeit.

Herrn Prof. Dr. A. v. Tiedemann danke ich für die Überlassung des Themas der vorliegenden Arbeit und seine freundliche Unterstützung.

Herrn Prof. Dr. W. Zeller danke ich für die Übernahme des Korreferates.

Herrn Dr. A. Mavridis danke ich besonders für die Einarbeitung in die klassische Phytobakteriologie, die ständige Diskussionsbereitschaft und viele weitere Anregungen.

Herrn Dr. B. Koopmann danke ich für das kritische Korrektur lesen des molekulargenetischen Teiles dieser Arbeit.

Herrn Dr. W. Pagel danke ich für seine Anregungen und Hinweise sowie das zur Verfügung gestellte Pflanzenmaterial.

Herrn Dr. F. Rabenstein und Dr. J. van der Wolf danke ich für die zur Verfügung gestellten Antikörper.

Frau Dr. I. Krämer danke ich für das zur Verfügung gestellte Primer-Paar.

Für die vielen anregenden Gespräche und Hinweise, die mir die Arbeit erleichtert haben, danke ich Prof. Dr. R. Heitefuß, Prof. Dr. G. Wolf und Dr. R. Rohringer.

Ein herzliches Dankeschön Frau Dr. Y. Aysan für die Zusammenarbeit im Gewächshaus in der BBA und die Versorgung mit Fachliteratur. 
Ich danke Herrn F. Sundmacher für die umfangreiche technische Unterstützung. Ebenso danke ich Herrn Dr. J. Leopold, Herrn D. Kopf, Herrn R. Heidhues und Frau. Dr. I. Schröder für die bereitwillige Auskunft im PC-Bereich.

Weiterhin möchte ich mich bei Herrn Dr. V. Hannemann für das sehr kritische Korrekturlesen bedanken.

Dankeschön an Frau Dr. Brielmaier-Liebetanz für die Versuchsdurchführung an der BBA in Braunschweig.

Frau Dr. B. Berkelmann danke ich für die zur Verfügungstellung der Bakterienkulturen.

Allen Institutsangehörigen, insbesondere der Arbeitsgruppe Phytobakteriologie, herzlichen Dank für die gute, angenehme und freundschaftliche Arbeitsatmosphäre, aber auch den “Wölfen“ und “Hoppes“. Den technischen Assistentinnen Heike, Michael, Sina, Annika und Yvonne sowie Radwan und Lutz, die mir alle beim Bearbeiten der Pflanzenproben und dem Pflanzentransfer geholfen haben, danke ich.

Frau Maack danke ich für die aufmunternden Gespräche.

Besonderer Dank gilt Herrn G. Silze für die zweijährige, finanzielle Unterstützung.

Meinem lieben Mann Dieter und meinen Söhnen Maik und Dirk gilt ganz besonderer Dank für das große Verständnis, die moralische Unterstützung und den Rückhalt in schweren Zeiten.

Meinen Eltern herzlichen Dank dafür, dass sie mir das Studium ermöglichten. 


\section{LEBENSLAUF}

Name

Geburtsdatum

Geburtsort

Familienstand

1970 - 1975

1975 - 1978

1978 - 1981

1982 - 1983

$1983-1988$

1989

1989 - 1991

$1992-1994$

1995 - 1996

1997
Hacer Batur-Michaelis

15.03.1963

Imranli, Türkei

Verheiratet, 2 Kinder

Grundschule Ismail Enderoni Ilkokulu in Ankara

Realschule

Gymnasium

Yalcinkaya Ortaokulu in Ankara

Etlik Lisesi in Ankara

Vorbereitung auf die Aufnahmeprüfung

der Universität Ankara

Universität Landwirtschaftsstudium an der

Universität Ankara

Abschluss: Examen als

Landwirtschaftsingenieurin

Sprachkurs am Goethe Institut in

Schwäbisch Hall

Sprachkurs „, Deutsch für Ausländer“ an der Universität Göttingen

Abschluss: PNdS

Studium am Institut für

Pflanzenpathologie und Pflanzenschutz an der Universität Göttingen

Abschluss: Magister scientiarum

agrariarum

Hausfrau, 2 Kinder

Beginn der experimentellen Arbeit zur vorliegenden Dissertation an der GeorgAugust-Universität in Göttingen 